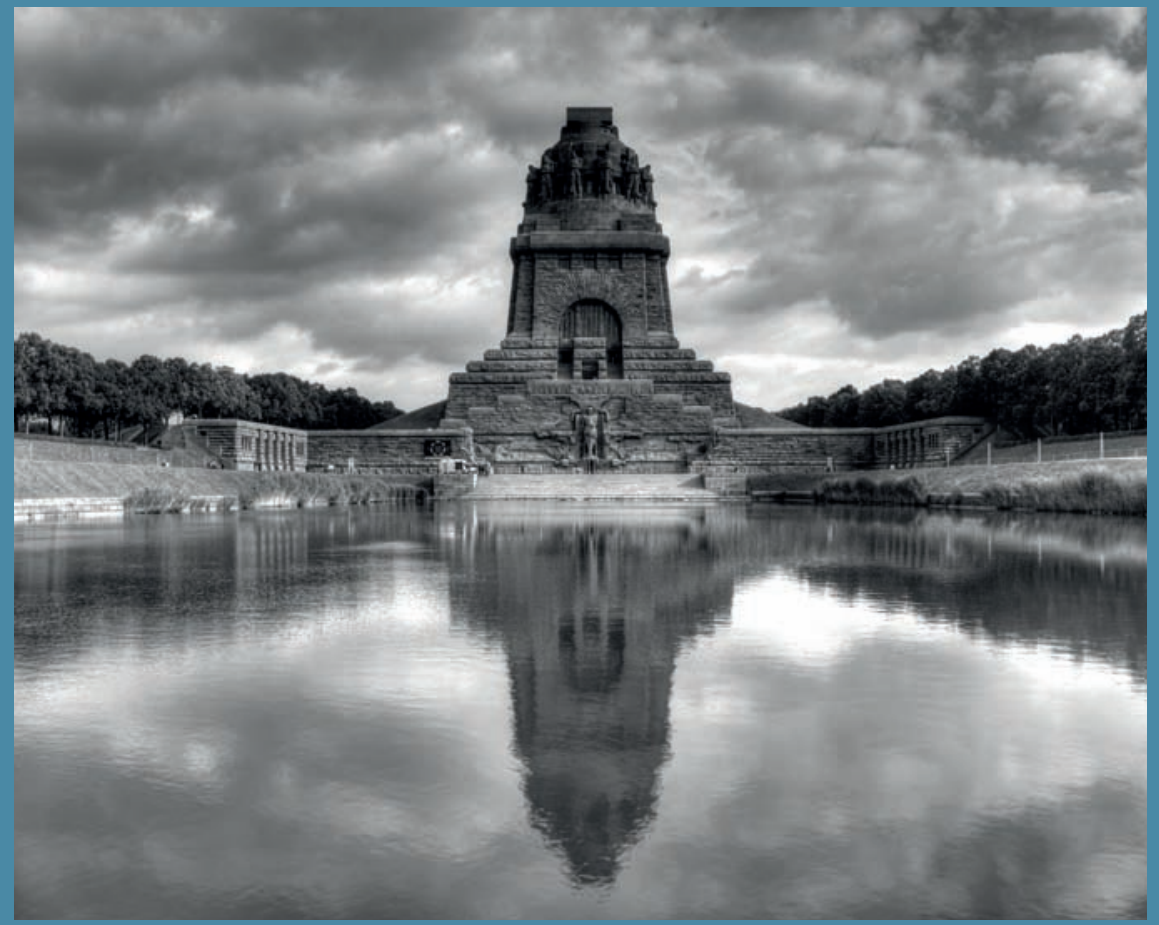

\title{
Völkisch Writers and National Socialism
}

A Study of Right-Wing Political Culture in Germany, 1890-1960

GUY TOURLAMAIN

Peter Lang 


\section{CULTURAL HISTORY AND}

LITERARY I MA GINATION

This book provides a view of literary life under the Nazis, highlighting the ambiguities, rivalries and conflicts that determined the cultural climate of that period and beyond. Focusing on a group of writers - in particular, Hans Grimm, Erwin Guido Kolbenheyer, Wilhelm Schäfer, Emil Strauß, Börries Freiherr von Münchhausen and Rudolf Binding - it examines the continuities in völkisch-nationalist thought in Germany from c.1890 into the post-war period and the ways in which völkisch-nationalists identified themselves in opposition to four successive German regimes: the Kaiserreich, the Weimar Republic, the Third Reich and the Federal Republic. Although their work predated Hitler's National Socialist movement, their contribution to preparing the cultural climate for the rise of Nazism ensured them continued prominence in the Third Reich. Those who survived into the post-war era continued to represent the völkisch-nationalist worldview in the West German public sphere, opposing both the Soviet and liberal-democratic models for Germany's future. While not uncontroversial, they were able to achieve significant publishing success, suggesting that a demand existed for their works among the German public, stimulating debate about the nature of the recent past and its effect on Germany's cultural and political identity and position in the world.

Guy Tourlamain received his D.Phil. from Oxford University in 2007. He also spent time as a visiting student at the University of Gießen, University of Hamburg and Humboldt University in Berlin as well as undertaking postdoctoral research at the German Literature Archive in Marbach am Neckar. From 2007 to 2012 he was Lecturer in Modern History at Liverpool Hope University. He currently lives and works in Bonn. 
Völkisch Writers and National Socialism 


\section{CULTURAL HISTORY AND LITERARY IMAGINATION EDITED BY CHRISTIAN J. EMDEN \& DAVID MIDGLEY}

VOL. 21

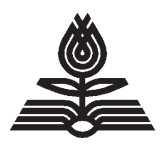

PETER LANG

Oxford · Bern • Berlin • Bruxelles · Frankfurt am Main • New York · Wien 


\title{
Völkisch Writers and National Socialism
}

\author{
A Study of Right-Wing Political Culture \\ in Germany, 1890-1960
}

Guy Tourlamain

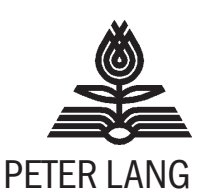

Oxford $\cdot$ Bern • Berlin • Bruxelles · Frankfurt am Main · New York • Wien 
Bibliographic information published by Die Deutsche Nationalbibliothek The Deutsche Nationalbibliothek lists this publication in the Deutsche Nationalbibliografie; detailed bibliographic data is available in the internet at http://dnb.d-nb.de.

An electronic version of this book is freely available, thanks to the support of libraries working with Knowledge Unlatched. KU is a collaborative initiative designed to make high quality books Open Access for the public good. More information about the initiative and links to the Open Access version can be found at www.knowledgeunlatched.org.

Open Access: The online version of this publication is published on www.peterlang.com and www.econstor.eu under the international Creative Commons License CC-BY-NC-ND 4.0. Learn more on how you can use and share this work: https://creativecommons.org/licenses/ by-nc-nd/4.0/.

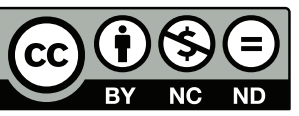

All versions of this work may contain content reproduced under license from third parties. Permission to reproduce this third-party content must be obtained from these third-parties directly.

Cover image: Monument of the Battles of the Nations (Völkerschlachtdenkmal) in Leipzig, Germany. Source: <http://commons.wikimedia.org/wiki/ File:Völkerschlachtdenkmal_(Monument_of_the_Battles_of_the_Nations).jpg > . Photo by Gunther Kuhnle, 2013. CC-BY-SA-3.0 license (<http://creativecommons. org/licenses/by-sa/3.0/deed.en>).

ISSN 1660-6205

ISBN 978-3-03911-958-5 (print)

ISBN 978-3-0353-0635-4 (eBook)

(C) Peter Lang AG, International Academic Publishers, Bern 2014

Hochfeldstrasse 32, CH-3012 Bern, Switzerland

info@peterlang.com, www.peterlang.com, www.peterlang.net

This publication has been peer reviewed. 


\section{Contents}

Acknowledgements

vii

Abbreviations

Introduction

CHAPTER I

'Wegbereiter' for the Nazis? Völkisch-Nationalist

Writers in Germany, 1870-1933

CHAPTER 2

Völkisch Writers and National Socialist Kulturpolitik

CHAPTER 3

The German Literature Academy:

Control Mechanism or Cauldron of Dissent?

CHAPTER 4

Beyond the Literature Academy

CHAPTER 5

Völkisch-Nationalism in the Post-War Era

Concluding Remarks

Select Bibliography

Index 



\section{Acknowledgements}

This book would not have been possible without the help of many people. I owe particular thanks to Anthony Nicholls at St Antony's College, Oxford, who, with his knowledge of German history, patiently guided me through my doctoral thesis, the starting point for this work. I would also like to thank Axel Schildt and Uwe Lohalm at the Forschungsstelle für Zeitgeschichte in Hamburg, Christoph Kleßmann of the Institut für zeithistorische Forschung in Potsdam and Siegfried Lokatis at the University of Potsdam, all of whom have given me the benefit of their advice. Peter Pulzer and Jeremy Noakes examined the original thesis, provided rigorous criticism and generous suggestions. Similarly, my thanks go to the editors of the Cultural History and Literary Imagination book series at Peter Lang, David Midgley and Christian Emden, for their careful reading of the text and comments based on their very considerable knowledge of the field. Yoav Alon, John Appleby, Frank Druffner, Jocasta Gardner, Randall Hansen, Bernhard Fulda and Zoe Waxman all read chapters at various stages. I am extremely grateful for their insights; any remaining flaws are my own.

I am also grateful to the staff of numerous libraries and archives in Germany, in particular the staff of the Forschungsstelle für Zeitgeschichte in Hamburg and the German Federal Archives in Berlin. Above all, without the help of the staff of the German Literature Archive in Marbach am Neckar this book would never have been completed.

One of the greatest challenges for such a project is that of funding. I am therefore extremely grateful to the Alfred Toepfer Stiftung F.V.S., whose award of a 'Hanseatic Scholarship for Britons' allowed me to spend two years studying in Hamburg and Berlin. I would also like to thank the Deutsche Schillergesellschaft Marbach, which provided me with a 'Marbach Stipendium' and two postdoctoral grants in order that I might carry out research at the German Literature Archive in Marbach am Neckar. Finally, a visiting research fellowship at the SFB 640 'Repräsentationen 
sozialer Ordnungen im Wandel' at the Humboldt University in Berlin in the autumn of 20 I I provided much needed resources and writing time.

Colleagues at Liverpool Hope University were also sources of advice and support, in particular John Appleby, Rachel Cowgill, Patrice Haynes, Jan Jobling, Terry and John Phillips and Fiona Pogson. The list of remaining friends who have kept me going is long. I thank them all! Steven and Jake gave me hospitality for a summer in San Francisco, where sections of the book were written; discussions with James Hanvey, Frank Gehring, Katharine Gilmartin, Philip Kennedy, Christian Könne and Kevin Kornegay provided feedback, encouragement and stimulus; John Worthen and Cornelia Rumpf-Worthen provided meals and a desk for the final phase. Finally this work would not have been possible without the support of Stefan Kirmse, who accompanied its production over many years.

I would like to thank all my family, but in particular, my uncle, Gordon Tourlamain, and his late wife Pauline, for both their moral and financial support, which made it possible to embark on this project in the first place. I dedicate this book to my parents, John and Moyra Tourlamain. 


\section{Abbreviations}

$\begin{array}{ll}\text { ALV } & \text { Albert-Langen Verlag } \\ \text { AV } & \text { Alldeutscher Verband } \\ \text { B.Arch. } & \text { Bundesarchiv, Berlin } \\ \text { DAF } & \text { Deutsche Arbeitsfront } \\ \text { DGB } & \text { Deutscher Gewerkschaftsbund } \\ \text { DHV } & \text { Deutschnationaler Handlungsgehilfen Verband } \\ \text { DNVP } & \text { Deutschnationale Volkspartei } \\ \text { DVP } & \text { Deutsche Volkspartei } \\ \text { DVSTB } & \text { Deutschvölkischer Schutz- und Trutz-Bund } \\ \text { FfZ } & \text { Forschungsstelle für Zeitgeschichte, Hamburg } \\ \text { GMV } & \text { Georg-Müller Verlag } \\ \text { HAVA } & \text { Hanseatische Verlagsanstalt } \\ \text { KfdK } & \text { Kampfbund für deutsche Kultur } \\ \text { LMV } & \text { Langen-Müller Verlag } \\ \text { NSDAP } & \text { Nationalsozialistische Deutsche Arbeiter Partei } \\ \text { PPK } & \text { Parteiamtliche Prüfungskommission zum Schutz des } \\ & \text { NS-Schriftums } \\ \text { RDS } & \text { Reichsverband deutscher Schriftsteller } \\ \text { RKK } & \text { Reichskulturkammer } \\ \text { RMVP } & \text { Reichsministerium für Volksaufklärung und Propaganda } \\ \text { RSK } & \text { Reichsschrifttumskammer } \\ \text { SDS } & \text { Schutzverband deutscher Schriftsteller }\end{array}$

Note on Translations

Unless otherwise stated, all translations from German texts are my own. 



\title{
Introduction
}

\author{
Im Gedicht bewahrt \\ eines Volkes Gedächtnis \\ seiner Besten Vermächtnis. \\ Im Gedicht späht \\ eines Volkes Gesicht \\ nach zukünftigem Licht. \\ Im Gedicht spricht \\ eines Volkes Gewissen sich selber Gericht.
}

In 1817 , a group of German students assembled at Wartburg Castle and burned books they believed were poisoning the true culture of the German Volk. ${ }^{2}$ On Ioth May 1933, students once again committed 'un-German' books to the flames in university towns across the newly established Third Reich. The motivation in both cases was to protect the German Geist. In 1933, the students acted according to clearly articulated principles, which stated that the roots of language and the written word lay in the Volk. ${ }^{3}$ Books and the printed word were not just ideological tools, but concrete expressions of the German Geist, which determined the Volk. As such, they were central to its cultivation and preservation, and an integral part of the continuing quest for a national identity and culture.

I Will Vesper, quoted in Hans Grimm, Über mich selbst und über meine Arbeit (Lippoldsberg: Klosterhaus-Verlag, 1975), p. 179.

2 George L. Mosse, The Crisis of German Ideology: Intellectual Origins of the Third Reich (New York: Schocken, 1964), p. 5.

3 Twelve Points of the Deutsche Studentenschaft, 13th April 1933, in H. Michaelis and E. Schraepler (eds), Ursachen und Folgen vom deutschen Zusammenbruch 1918 und 1945 bis zur staatlichen Neuordnung Deutschlands in der Gegenwart (Berlin: H. Wendler, I964), vol. IX, pp. 486-488. 
This book is concerned with the role of the written word in the articulation and dissemination of völkisch-nationalism in Germany between 1890 and around 1960, and with the writers who produced it. Focusing on Hans Grimm and Erwin Guido Kolbenheyer in particular, but including too their colleagues, friends and associates (for example Wilhelm Schäfer, Emil Strauß, Börries Freiherr von Münchhausen, Agnes Miegel and Rudolf Binding), it examines the ways in which völkisch-nationalists identified themselves in opposition to four successive German regimes: the Kaiserreich, the Weimar Republic, the Third Reich and the Federal Republic. These writers were not the products of Hitler's National Socialist movement but were established in their own right as spokespeople of the nationalist right before 1933. Their contribution to preparing the cultural climate for the rise of Nazism ensured them continued prominence in the Third Reich, but their relationship with the Nazi government was often ambiguous.

At different stages in their careers all the writers dealt with in this book produced autobiographies or works - novels, plays, poetry and non-fiction - commenting on the political and social upheavals they lived through. Grimm and Kolbenheyer also wrote lengthy commentaries seeking to explain Germany's situation after $1945 ;{ }^{4}$ they provided a völkisch-nationalist interpretation of German history and politics, and the importance of 'German' literature in a national society. This book also considers the formal and informal networks to which these writers belonged: networks providing a framework for the articulation and dissemination of a racist and nationalist worldview which, they stressed, differed from that represented by National Socialism.

The ambiguous relationship that developed between the völkisch-nationalist writers in question and the Nazi regime is central to understanding their position after 1945. Their conviction - established before 1933 - that, as the representatives of German national literature,

4 Hans Grimm, Die Erzbischofschrift: Antwort eines Deutschen (Göttingen: PlesseVerlag, 1950); Hans Grimm, Warum - Woher - Aber wohin? Vor, unter und nach der geschichtlichen Erscheinung Hitler (Lippoldsberg: Klosterhaus-Verlag, 1954); Hans Grimm, Über mich selbst; Erwin Guido Kolbenheyer, Sebastian Karst: Über sein Leben und über seine Zeit, 3 vols (Gartenberg bei Wolfratshausen: KolbenheyerGesellschaft, 1955, 1957, 1958). 
they had both a right and a duty to pronounce on the country's future direction remained unaltered after 1945; indeed, in several cases this conviction increased in response to the foundation of the Federal Republic of Germany (FRG). They opposed both the soviet and liberal-democratic models for Germany's future. While far from uncontroversial, they achieved significant publishing success, suggesting that a demand existed for their works among the German public. Their lectures were well attended and they received attention in the national as well as regional and local press, stimulating debate about the nature of the recent past and its effect on Germany's cultural and political identity and position in the world. The efforts of these writers to make German nationalism relevant to post-war Germany were significant for the process of cultural transformation in the I950s, exacerbating the contradictions and tensions between modernisation and restoration in Germany's changing social climate.

Völkisch-nationalist ideas provided a reference point from which the writers in question reacted to specific social and political contexts. Inevitably, the historical conditions in which their ideas were applied in turn affected their articulation, but the lines of ideological continuity in the development of völkisch-nationalist thought from the late nineteenth century into the $1950 \mathrm{~S}$ are clear. It was an ideology used both to explain Germany's problems and as the basis for a proposed solution. Its principal impetus was not, as might initially be concluded, anti-modern; rather it was an attempt, in the light of an ideology which identified a Germany defined by the Volk, and focused on definitions of Germany and the German people according to history, language and, most significantly, blood, to change the course toward modernity on which Germany appeared set after I870. 1933 did not, therefore, mark a break in the völkisch literary tradition; instead this literature mirrored right-wing ideologies developed in the face of successive challenges to traditional German social structures. These challenges allowed völkisch-nationalist writers to find readers for works that sought to build a new sense of national community, works that the Nazis sought to instrumentalise for their own ends. ${ }^{5}$

$5 \quad$ Helmut Vallery, 'Völkisch-nationalsozialistische Erzählliteratur', in H. Glaser and A. von Bormann (eds), Deutsche Literatur, eine Sozialgeschichte - Band 9: Weimarer 
Following German unification in 1871 , the question of what constituted the nation and who belonged to it remained of fundamental importance for German nationalists. It was a political ideology that claimed authority not from institutional power but directly from the German people. The belief that völkisch-nationalism was a 'movement' was important for its adherents; it reassured them that the diverse activities of the numerous völkisch groups and organisations contributed to something larger.

The idea of a völkisch movement has also proved useful to historians. Nonetheless, völkisch-nationalist circles lacked institutional unity and it might be argued that to speak of a 'völkisch movement' is overstating the case. Instead of a single, organised political force, an uncoordinated collection of völkisch groups and individuals emerged. Their common ground was limited to agreement that the German nation should be based on the concept of the German Volk, defined in racial terms. In spite of successive attempts by völkisch-nationalists to bring about a greater degree of institutional unity, this was never a movement of associated writers and academics, or a cohesive programme for political or social reform. Ideological cohesion depended to a large extent on the printed word. ${ }^{6}$ In addition to the journals, newspapers and magazines produced by völkisch organisations, books were vital in articulating and disseminating völkisch-nationalist ideas. They also contributed to the formation of an ideology in a state of constant development.

While some academic literature exists on völkisch-nationalism in the Kaiserreich and the Weimar Republic, a close ideological association with Nazism has made it easy to dismiss völkisch writers as the literary precursors and representatives of National Socialism. ${ }^{7}$ Such a view, however, among

Republik - Drittes Reich: Avantgardismus, Parteilichkeit, Exil, IgI8-I945 (Reinbek: Rowohlt, 1989), pp. I44-I54.

6 Uwe Puschner, Die völkische Bewegung im wilhelminischen Kaiserreich: Sprache, Rasse, Religion (Darmstadt: Wissenschaftliche Buchgesellschaft, 200I), pp. I43-I45.

7 See, for example Ernst Loewy, Literatur unterm Hakenkreuz: Das Dritte Reich und seine Dichtung. Eine Dokumentation (Frankfurt am Main: Hain, 1966), p. II; Ralf Schnell, 'Was ist "Nationalsozialistische Dichtung”?' in Jörg Thuneke (ed.), Leid der Worte: Panorama des literarischen Nationalsozialismus (Bonn: Bouvier, 1987), pp. 28-45; Jürgen Hillesheim and Elisabeth Michael, Lexikon nationalsozialistischer 
other things, fails to recognise the personal and political differences that also developed between these writers and the Nazis and overlooks their cultural significance both before 1933 and after the Second World War.

The history of völkisch-nationalism can be traced back beyond I87I, although the term völkisch was only applied from the early twentieth century. ${ }^{8}$ Among a number of figures prominent in nineteenth-century German cultural life, Houston Stewart Chamberlain, Paul de Lagarde and Julius Langbehn all contributed to the intellectual context in which a nationalist ideology based on the idea of a racially defined German Volk became increasingly attractive to significant sections of the German population, particularly members of the middle classes who felt threatened by social change. Alongside cultural journals and enterprises, the numerous patriotic and nationalist organisations in Germany were particularly important in the dissemination of such an idea, providing a readership for völkisch literature. These organisations, in turn, increasingly adopted its racial worldview, often, but not always, linked to anti-Semitism.

Since 1945 it has not been possible to deal with the history of the German right without addressing the question of National Socialism. ${ }^{9}$ The search for the underlying roots of the Third Reich and the acquiescence of the German population under Hitler has led to a number of approaches, ideological, sociological and cultural as well as political. A large number of works have been produced that seek to identify the moment at which fascism first became a possibility in Germany, how it developed, and why it eventually gained a hold on German life in the form of National Socialism. ${ }^{10}$ Völkisch-nationalism has inevitably been examined

Dichter: Biographien - Analysen - Bibliographien (Würzburg: Königshausen \& Neumann, 1993), p. 7.

8 Puschner, Die völkische Bewegung, p. I4.

9 Stefan Breuer, Die Völkischen in Deutschland (Darmstadt: Wissenschaftliche Buchgesellschaft, 2008), pp. 7-8.

Io The specificity of Germany's development, or Sonderweg, in the century preceding 1933 has been the subject of involved discussion. Eley emphasises the role of the 'Fischer Controversy', 'about the nature of German imperialism and its aims in the First World War', in pushing young German historians in the mid-I960s to direct their attention 
as a pre-Nazi or proto-fascist phenomenon in the context of Germany's response to modernity at the end of the nineteenth and in the early twentieth centuries. Until relatively recently, however, little attention has been paid to the differences on the far right in Germany under the Nazis, or to the continued activities of adherents to völkisch thought after 1945. ${ }^{11}$

The question of the modern in the context of the far right in Germany has posed scholars of both history and literature with a challenge. The aesthetic expressions of the far right in Germany, compared for example with the relationship between Italian Fascism and futurism, tended to draw on conservative traditions in an effort to defend 'German' culture from the challenges of the internationalism identified in more avant-garde movements. The Nazis' failure to establish a monolithic cultural or literary sphere is well established. Nonetheless, the ongoing scholarly emphasis has been on the place of literary life within the power-structures of the regime and the instrumentalisation of the written word in the name of National Socialism. Reflecting on the implications of this for modern

'to the problem of continuity and the place of Nazism in the longer historical experience between Bismarck and Hitler': GeoffEley, Reshaping the German Right: Radical Nationalism and Political Change after Bismarck (New Haven: Yale University Press, I980), pp. 2-3. The weaknesses of the Sonderweg idea have been extensively discussed in Blackbourn and Eley, The Peculiarities of German History: Bourgeois Society and Politics in Nineteenth-Century Germany (Oxford: Oxford University Press, 1984) pp. 2-6 and Jürgen Kocka, 'Asymmetrical Historical Comparison: The Case of the German Sonderweg', History and Theory 38 (1999), No. I, p. 4I. From the 1950s, a number of historians also began to consider the roots of National Socialism through the history of ideas, ideologies and cultural developments. See, for example, Mosse, The Crisis of German Ideology; Fritz Stern, The Politics of Cultural Despair: A Study in the Rise of the Germanic Ideology (Berkeley: University of California Press, 196I); Kurt Sontheimer, Antidemokratisches Denken in der Weimarer Republik: Die politischen Ideen des deutschen Nationalismus zwischen 1918 und 1933 (Munich, revised edition: dtv, 1978); Hans Kohn, The Mind of Germany (London: Macmillan, 1966).

II Among the exceptions are Werner Mittenzwei, Der Untergang einer Akademie oder die Mentalität des ewigen Deutschen (Berlin: Aufbau, 1992). For the post-1945 period see Kurt Tauber, Beyond Eagle and Swastika: German Nationalism since 1945 (Middletown: Wesleyan University Press, 1967); Rand C. Lewis, A Nazi Legacy: Right-Wing Extremism in Postwar Germany (New York: Praeger, 1991). 
German culture, Ketelsen has suggested that it has allowed 'Nazi' literature to be viewed as somehow other to subsequent German literary developments, which have therefore been able to identify their antecedents in the 'good' German literature of exile or inner-emigration. This has been possible because of the prominence of Blut-und-Boden romanticism, which did indeed harness the völkisch tradition to the Nazi cause. ${ }^{12}$ As a result, in the literary context 'Nazi' has frequently been viewed as synonymous with völkisch and anti-modern, allowing for a contrast with the 'modern' literature of the Weimar Republic and post-Second World War period. ${ }^{13}$

It is too straightforward to present the literature of völkisch-nationalism solely as the basis of National-Socialist literary expression. Due to the lack of original literature emerging from Nazi ranks, völkisch works became the serious literary representation of the regime almost by default. But the attitude of their writers towards the Nazi government often remained ambiguous, necessitating a differentiated approach on the part of historians. By describing them as 'National Socialist' or 'Pre-National Socialist', the significance of these works for the period in which they were written has been rendered negligible beyond the context of the Third Reich. Yet, during the Weimar Republic völkisch writers contributed to broader right-wing opposition to republicanism and democracy. That this helped prepare the ground for the Nazis does not mean that the regime after 1933 was the goal of the writers in question. And even pledges of support for the Third Reich as the Nazis took power did not signal the end of the story; in many cases, the position of völkisch-nationalist writers turned out to be very different from the one

Uwe-K. Ketelsen, 'NS-Literatur und Modernität', in Wulf Koepke and Michael Winkler (eds), Deutschsprachige Exilliteratur: Studien zu ihrer Bestimmung im Kontext der Epoche 1930 bis 1960 (Bonn: Bouvier, 1984), pp. 37-55.

I3 See, for example Ernst Loewy, Literatur unterm Hakenkreuz, p. II; RalfSchnell, 'Was ist "Nationalsozialistische Dichtung"?' in Thuneke (ed.), Leid der Worte, pp. 28-45; Jürgen Hillesheim and Elisabeth Michael, Lexikon nationalsozialistischer Dichter, p. 7; Klaus Vondung, Völkisch-nationale und nationalsozialistische Literaturtheorie (Munich: List, 1973), p. I0; Klaus Vondung, 'Der literarische Nationalsozialismus. Ideologische, politische und sozialhistorische Wirkungszusammenhänge', in Denkler and Prümm (eds), Die deutsche Literatur im Dritten Reich: Themen - Traditionen Wirkungen (Stuttgart: Reclam, 1976), pp. 51-52. 
they had imagined for themselves. ${ }^{14}$ Likewise membership of the NSDAP did not necessarily mean that a writer placed himself or herself unequivocally at the Party's disposal. These categories were relatively arbitrary in the development of a writer's relationship with the regime. Strauß, for example, was a member of the NSDAP, but less politically active than Grimm. While neither can be credited with outright opposition to the regime, both were critical in private and, at times, also in public. In the 1930s, völkisch-nationalist writers increasingly resorted to expressing their ideas in correspondence and dialogue with each other. An examination of Grimm's papers, for example, produces a picture of a more intricate web of interlocking ideological networks and associations than has usually been acknowledged. ${ }^{15}$

It is noteworthy, moreover, that not only did the völkisch-nationalist writers examined here take their own work seriously, but it was also recognised as the serious literary representation of the right by the German public from the Kaiserreich to 1945. There was a market for their work and they were honoured with literary prizes and membership of literary institutions before 1933. These writers were part of mainstream literary life in Germany in the early twentieth century; they all engaged with the literary world as producers of more than just 'Unterhaltungsromane' or 'Trivialliteratur'. The large print-runs of their work are also a reminder that, while they and the Nazis shared a common racist ideology, völkisch sentiment needs to be recognised as a response to deeply ingrained social and political concerns in Germany. It was not a product of National Socialism. ${ }^{16}$

In promoting greater understanding of the internal dynamics of the völkisch phenomenon, Uwe Puschner provides analysis based round three pillars: language, race, and religion. ${ }^{17}$ Using these central elements, which he describes as the 'weltanschauliche Dreiheit' of the völkisch movement,

I4 Vondung, 'Der literarische Nationalsozialismus', pp. 60-6r.

Is Grimm's extensive Nachlaß is held in the German Literature Archive (DLA) in Marbach am Neckar and has provided a significant amount of the archival material on which this study is based. I am grateful to the German Literature Archive and the German Schiller Society for a number of scholarships to support my exploration of Grimm's papers.

I6 Vallery, 'Völkisch-nationalsozialistische Erzählliteratur', pp. I44-I54.

I7 Puschner, Die völkische Bewegung, pp. I4-I8. 
Puschner identifies its 'spiritual' roots and tracks the efforts of völkischnationalists to lay the foundations of their ideology. Highlighting the existence of contradiction in völkisch-nationalism before 1918 , he moves beyond the examinations of the esoteric side of völkisch ideology offered by Nicholas Goodrick Clark and Rüdiger Sünner through an examination of ideological dialogue on the right in the Imperial period. ${ }^{18}$

Stefan Breuer takes a broader view that also discusses representatives of völkisch thought in the Weimar Republic and the Third Reich. He points out that concentrating on the Weltanschauung of völkisch-nationalism, or focusing on its religious or esoteric tendencies, runs the risk of an unbalanced account favouring the margins of the German right and tending to neglect the widespread acceptance of völkisch ideas among mainstream sections of the population, particularly the professional middle classes. $\mathrm{He}$ also argues against an identification of völkisch-nationalism with biological racism, suggesting that it closes down the possibility of including categories such as Geist, Seele or Gestalt. ${ }^{19}$

Yet the work of völkisch-nationalist writers reveals an understanding of the latter categories as among the inherited characteristics of the Volk; both its physical and 'spiritual' attributes were transferred through the blood. In this way, biological racism lay at the heart of völkisch thought; in the same way it was also intrinsic to Nazi racial theory. Similarly, while nationalism and racism did not always coincide in Germany, völkisch thought rested on both phenomena, hence the adoption of the hyphenated term völkisch-nationalism here. The common understanding of the Volk in the period under consideration was fundamentally based on the idea of an ethnically related people; the nation-state when fully developed would encompass the whole German race. ${ }^{20}$

I8 Nicholas Goodrick-Clarke, The Occult Roots of Nazism: The Ariosophists of Austria and Germany, I890-1935 (Wellingborough: Aquarian, 1985); Rüdiger Sünner, Schwarze Sonne: Entfesselung und Missbrauch der Mythen in Nationalsozialismus und rechter Esoterik (Freiburg: Herder, 1999).

I9 Breuer, Die Völkischen in Deutschland, pp. 9-I2.

20 See for example: Guy Tourlamain, 'Resisting Change: Erwin Guido Kolbenheyer and "Sudeten German" Identity in West Germany after the Second World War', Transtext(e)s Transcultures, No. 4 (2008), pp. 130-I45. 
Breuer is, however, right to warn that an overemphasis on the irrational, mystical, romantic and culturally pessimistic elements can lead to a failure to recognise the optimism that the völkisch ideology engendered in its adherents, and the faith in (pseudo-) scientific approaches to the world it also encouraged. ${ }^{21}$ The last is illustrated, for example, in the interest many völkisch-nationalists demonstrated in eugenics and racial hygiene. ${ }^{22}$ Thus, völkisch-nationalism should not be viewed as anti-modern, but, Breuer argues, as a search for a solution to the negative aspects of modernity, in particular the social fragmentation it engendered. This provides him with the basis for his approach to the völkisch phenomenon, which, he argues, had at its core a desire for harmony or wholeness. Thomas Rohkrämer's understanding of the development of the German right and the roots of Nazism is similar. He emphasises 'the growing desire for a single communal faith in Germany' that was addressed for many in the völkisch ideal of a Volksgemeinschaft. ${ }^{23} \mathrm{He}$ suggests that this ideal, fundamental to German nationalism, was seized on by large sections of the population by 1933 in response to the increasingly polarised political and social realities in which they lived. This search for harmony or communal unity cannot, however, be viewed as exclusive to the völkisch right. It has been identified across the spectrum of ideological and intellectual movements in Germany in the early twentieth century; Peter Gay's work on the Weimar Republic points out that a desire to achieve wholeness underlay the idealism of a range of groups, from the youth movements to the Bauhaus. ${ }^{24}$

These works all recognise völkisch-nationalism as a product of the far right during the Kaiserreich. Discussion of its continued development and ongoing impact after 1918 , however, is complicated by scholarly discussions of the concept of the 'conservative revolution', which has dominated the

Breuer, Die Völkischen in Deutschland, pp. 9-12.

Michael Burleigh, Death and Deliverance: Euthanasia in Germany, 1900-1945 (Cambridge: Cambridge University Press, 1994), chapter one.

23 Thomas Rohkrämer, A Single Communal Faith: The German Right from Conservatism to National Socialism (Oxford: Berghahn, 2007), p. I.

24 Peter Gay, Weimar Culture: The Outsider as Insider (London: Secker \& Warburg, I968), p. 8I. 
historiography of the nationalist right in Germany in the years after I9I8. This concept has proved confusing. ${ }^{25}$ One of the first uses of the term was in an essay by Hugo von Hofmannsthal, 'Das Schrifttum als geistiger Raum der Nation', in $1927 .{ }^{26}$ While Hofmannsthal described something that was more profound than most anti-democratic, nationalist thought in the Weimar Republic, his description of the 'conservative revolution' does point to one way in which the far right, as opposed to more traditional conservatives, understood their own ideological position: they saw themselves as the vanguard in Germany, striving for the renewal of the nation, reflecting the revolutionary idealism of radical nationalist ideologies in the I920s, including völkisch-nationalism.

The first post-1945 instance in which the 'conservative revolution' was examined is Armin Mohler's dissertation, submitted at the University of Basle in 1949 and published the following year. ${ }^{27}$ Mohler's application of the term encompassed five distinct groups within German nationalism: the Völkische, the Nationalrevolutionäre, the Jungkonservative, the Bündische and the Landvolkbewegung. In a revised edition of his work published in 1989, the last two categories were removed. His goal was to identify the anti-democratic, anti-liberal movements in Germany, separating them from both National Socialism and traditional reactionary conservatism. In distancing them from the National Socialists in particular, he displays what Ketelsen refers to as 'rettende Intentionen. ${ }^{28}$ Mohler's own biography makes

25 Both Breuer and Woods take this as the starting point for their examinations of the 'conservative revolution'. See Stefan Breuer, Anatomie der konservativen Revolution (Darmstadt, 2nd revised edition: Wissenschaftliche Buchgesellschaft, I995), p. I; Roger Woods, The Conservative Revolution in the Weimar Republic (Basingstoke: Macmillan, 1996), p. 72.

26 Detlev W. Schumann, 'Gedanken zu Hofmannsthals Begriff der "Konservativen Revolution”, PMLA, 54, No. 3 (September 1939), pp. 855-899.

27 Armin Mohler, Die konservative Revolution in Deutschland, 1918-1932: Ein Handbuch (Stuttgart: Vorwerk, 1950; Revised edition: Darmstadt: Wissenschaftliche Buchgesellschaft, 1989).

28 Uwe-Karsten Ketelsen, Völkisch-nationale und nationalsozialistische Literatur in Deutschland, I89o-1945 (Stuttgart: Metzler, 1976), p. 47. See also Woods, The Conservative Revolution, p. II3. 
his intention to rescue the writers from the Nazi label unsurprising. Born in Switzerland in 1920 , in 1942 he volunteered for the German army. Following differences of opinion with his Nazi superiors, he flirted with both the extreme left and the extreme right, before returning to Switzerland to take up his studies in Basle. By the time his dissertation was published in 1950 he had returned to southern Germany, where he worked as the private secretary of Ernst Jünger, one of the writers he sought to 'rescue. ${ }^{.29}$ Nonetheless, his efforts to create a more differentiated view of the German right are not without foundation. Such a view does not, however, lead to exoneration of those it highlights from their contributions to the environment in which the Nazis were able to flourish. Neither does it, in most cases, reflect any moral outrage on their part at Nazi racism, but instead the elitist attitudes of many nationalists towards the mass nature of the Nazi movement.

Since the appearance of Mohler's work there has been a tendency to apply the term 'conservative revolution' in the Weimar period to denote a right-wing discourse in which certain themes formed a core. These have included the concepts of the Führerprinzip and the Volksgemeinschaft as the basis for the German nation. ${ }^{30}$ The assertion that these ideas should be distinguished from 'old-style' nationalist ideologies, with the implication that they represent a reaction to the outcome of the First World War, was, however, convincingly challenged in the 1960 os by historians like Fritz Stern and George Mosse. ${ }^{31}$ More recently, Jost Hermand has also demonstrated an ideological continuity on the right from the Kaiserreich to the Weimar Republic based on these ideas. ${ }^{32}$

Waldemar Gurion, 'Conservative Revolution in Germany', The Review of Politics, I3, No. 3 (July 195I), p. 395; E. Rosenbaum, 'Die Konservative Revolution in Deutschland, 1918-1932: Grundriss ihrer Weltanschauungen', International Affairs 27, No. 2 (April 195I), pp. 240-24I.

30 For example: Klemens von Klemperer, Germany's new Conservatism (Princeton: Princeton University Press 1957); Kurt Sontheimer, Antidemokratisches Denken, p. I44.

3I Fritz Stern, The Politics of Cultural Despair; George L. Mosse, The Crisis of German Ideology.

32 Jost Hermand, Der alte Traum vom neuen Reich. Völkische Utopien und Nationalsozialismus (Frankfurt am Main: Athenäum, 1988). 
In the light of the drawbacks identified by these scholars, in Anatomie der konservativen Revolution Stefan Breuer investigates whether a common core existed between intellectuals typically categorised as 'conservative revolutionaries', concluding that the term is inadequate as an umbrella for radical nationalism in the Weimar Republic. ${ }^{33}$ Most works on the 'conservative revolution' have emphasised the concept as representing new developments in right-wing, nationalist thought in the Weimar Republic. ${ }^{34}$ Nonetheless, a greater degree of differentiation is still needed between a fundamentally new ideology, and the application of older ideas to new contexts. Roger Woods recognises the existence of a 'conservative revolution' that was a counter-movement to the French Revolution, opposing liberalism, socialism, democracy and internationalism. Thus defined, it extended back into the early nineteenth century. ${ }^{35} \mathrm{He}$ argues that the switch 'away from a call for clarity over political aims towards anti-programmatic activism and the idea of a strong leader is one of the major developments in their [conservative revolutionaries'] thought in the Weimar Republic.' ${ }^{36}$ This does not, however, sufficiently differentiate a clear 'conservative revolutionary' way of thinking from the völkisch-nationalists discussed in this book. The call for a strong leader was a principle also evident in the antipathy of völkisch-nationalists to the parliamentary system in the Kaiserreich. ${ }^{37}$ And in the republican context of the Weimar system, nationalists of all shades emphasised this alternative to parliamentary democracy more strongly. Germany's defeat in the First World War also gave their nationalism new momentum, while the 1918 revolution made radical change seem both necessary and more possible than it had been

33 Breuer, Anatomie der konservativen Revolution, pp. 5-6 and passim.

34 See, for example, Panajotis Kondylis, Konservatismus (Stuttgart: Klett-Cotta, 1986), pp. 469-493.

35 Woods, The Conservative Revolution, p. I.

36 Ibid. pp. 73-74.

37 See, for example, Houston Stewart Chamberlain, Die Grundlagen des neunzehnten Jahrbunderts (1899; edition used: Munich: Bruckmann, 1935) pp. 25-26; 348-350; Paul de Lagarde, 'Konservativ' (essay written in I853, reproduced in Schriften für das deutsche Volk, Munich: Deutsche Buchgemeinschaft, 1934), p. 2 I. 
during the Kaiserreich. Their responses to the Weimar Republic still rested, however, on ideas established before I9I4.

The concept of the 'conservative revolution' is also linked to the idea of 'reactionary modernism' put forward by Jeffrey Herf. He formulates this as the reconciliation of the nationalist neo-romanticism of the nineteenth century with modern technology in the Weimar Republic. The use of metaphors, familiar words and expressions, he argues, 'had the effect of converting technology from a component of alien, western Zivilisation into an organic part of German Kultur. ${ }^{38}$ Thus, according to Herf, the antimodernist nature of German nationalism, which he blames on its separation from the Enlightenment, was overcome by some 'conservative revolutionaries' after 1918 . Herf is right to challenge the assumption that right-wing thought was intrinsically anti-modern. At the same time he accepts the same assumption for the earlier nationalists, among whom he includes the völkisch movement. ${ }^{39}$ In fact, the paradox he identifies in 'reactionary modernism' was also evident in völkisch-nationalism, which rejected the Enlightenment and rationalism, but accepted the scientific and technological progress of modernity. In particular, völkisch-nationalists sought to justify their racial theories through pseudo-scientific, social-Darwinist ideas. Moreover, the colonial empire that was, for example, advocated by the Alldeutscher Verband and which is central to Grimm's novels required the modern battleships demanded by the Navy League. Technology also featured in their novels. Gustav Frenssen's best-known protagonist, the farmer Jörn Uhl, ended his days as an engineer working on the construction of the Kaiser Wilhelm Canal, in the eyes of German nationalists a proud symbol of Germany's position among the most advanced nations of the world. ${ }^{40}$

Already in the Kaiserreich, völkisch-nationalists represented a growing demand for active, even revolutionary change. As a result, they were part of what Jeremy Noakes identifies as the 'new right' in Imperial Germany. and the Third Reich (Cambridge: Cambridge University Press, 1984), p. I. Ibid., p. I5.

40 Gustav Frenssen, Jörn Uhl (Berlin: Grote, 1901). 
In the face of the weakness of the traditional conservative parties, traditional conservatives sought to harness the 'new right', adopting its rhetoric while seeking to maintain their own hold on power. In doing so they gave legitimacy to values based on the idea of the Volk, which increasingly set the ideological terms of the German right in general. ${ }^{41}$ Eley identifies two stages in the development of the 'new right', the first between about 1890 and 1908 , in which it developed an anti-parliamentary, radical nationalist discourse in opposition to the established ruling groups. This was followed by the unexpected readmission of the 'new right' into the right-wing mainstream that began in 1907-1908 and increased after the Second Moroccan Crisis in I9II and the success of the SPD in the Reichstag election in I9I2. This was the start of a radicalisation that, he suggests, continued through the 'double trauma' of defeat and revolution in 1918 and on into the early I920s. Nonetheless, this radicalisation remained an ideological achievement, which failed to create sufficient social and institutional cohesion to turn it into political power. ${ }^{42}$ This was only achieved by the Nazis after 1928 , in the process, as Noakes observes, highlighting the bourgeois character of the 'new right', in spite of its radical rhetoric. ${ }^{43}$

Overall, the term 'conservative revolution' is inadequate to describe the writers examined in this book. As applied by scholars, it does not sufficiently describe the continuities which can be traced through the radical, revolutionary nature of their ideology in the Kaiserreich, its violently oppositional character in the Weimar Republic, and its challenging stance regarding the Third Reich. Presenting a different approach to providing a framework to describe the far right, Werner Mittenzwei's extensive study of the Literature Section of the Prussian Academy of Arts recognises the ideological continuity from the Kaiserreich to the Weimar Republic. Instead of 'conservative revolution', Mittenzwei uses the term Nationalkonservative

4I Jeremy Noakes, 'German Conservatives and the Third Reich: an ambiguous relationship', in Martin Blinkhorn (ed.), Fascists and Conservatives. The radical right and the establishment in twentieth-century Europe (London: Unwin Hyman, 1990), p. 72.

42 GeoffEley, 'Conservatives and radical nationalists in Germany: the production of fascist potentials, 1912-1928', in Martin Blinkhorn (ed.), Fascists and Conservatives, p. 62.

Noakes, 'German Conservatives', pp. 73-74. 
(national conservatives). With respect to Hans Grimm and his closest associates, he also suggests that they were bound together more by their aversion to artistic modernism than their political points of view. ${ }^{44}$ Nonetheless, Grimm and Kolbenheyer, in particular, consistently identified themselves as political writers. Others, like Wilhelm Schäfer, were more inclined to draw a line between literature and politics. Even Schäfer, however, described his most successful work Die dreizehn Bücher der deutschen Seele as politically motivated under the exceptional circumstances of the early Weimar Republic. ${ }^{45}$ Moreover, the cooperation of these writers with each other during the r930s was a response to the institutional frameworks created by the Nazis in the politics of culture.

The political character of their ideology has led Rolf Geißler to endorse the dichotomy between the aesthetic and the political using the term völkisch-national. Völkisch, he suggests, refers to the aesthetic vision of a Volksgemeinschaft and the defining qualities of the Volk's blood; 'national' refers to the political characteristics of the nation, incorporated in the authoritarian state. ${ }^{46}$ Nonetheless, the hyphenation of the terms völkisch and nationalist does not reflect the writers' own view of their ideological position, but remains an academic construct to describe the nature of a complex ideology. It is used as such in this book, which recognises that categorisation in this instance requires uncovering similarities and acknowledging the overlapping character of the many nationalist groups and organisations, and the influence they exercised over each other. The völkisch-nationalist worldview presents the challenge of finding a formula that reflects the fluid boundaries of ideological positions operating in broader social contexts, and the often paradoxical nature of an ideological standpoint that appealed to both emotion and reason.

44 Werner Mittenzwei, Der Untergang einer Akademie, p. 84 and passim.

45 Wilhelm Schäfer, Mein Lebenswerk. Dankrede bei der Verleibung des Rheinischen Literaturpreises in Köln am 13. November 1937 (Munich: Langen-Müller, 1938), pp. 4-5.

46 Rolf Geißler, 'Dichter und Dichtung des Nationalsozialismus', in H. Kunisch (ed.), Handbuch der deutschen Gegenwartsliteratur (Munich: Nymphenburger Verlagshandlung, 1965), p. 721. 
Conscious of the breadth and disparities in völkisch circles, therefore, this book defines völkisch or völkisch-nationalist broadly as an ideology that was carried beyond straightforward identification with the German 'nation' by a belief and emphasis on a racially defined Volk as the basis for society. Puschner's description of the völkisch movement as a 'Gesamtbewegung' with 'weltanschaulicher Breite' provides the basis for understanding the phenomenon here. ${ }^{47}$ This broad definition also draws on the work of George Mosse, who employs the word 'volkish' in his works to designate any ideology or worldview that had the idea of the German Volk at its centre. ${ }^{48}$ Such a broad approach is also used by Hermand to significant effect in his discussion of völkisch utopias in Germany from the Kaiserreich to the end of the Third Reich. ${ }^{49}$

Following a background chapter on the history of völkisch-nationalist thought from the nineteenth century, this book examines the enthusiasm with which völkisch writers greeted the Third Reich, their vision for Germany's future and their subsequent disillusionment, by exploring their involvement in the cultural and literary life of these years and their efforts to address the history of the Nazi regime after 1945 .

The First World War was a defining event for the writers that provide the focus of this book, the experience binding them together during the Weimar Republic. In many ways, the outbreak of war in 191 4 was the high point of Wilhelmine völkisch-nationalism: the war was expected to cleanse German society of degeneracy so that a völkisch state could be built on the undoubted German victory. The war did not substantially change the nature of the ideology, but defeat gave it new momentum and focus. During the I920s, völkisch writers renewed their pre-war opposition to socialism and democracy, which they now identified as the foreign driving forces of the Weimar Republic. Their works provided a völkisch analysis of Germany's situation and attempted to overcome the loss of national dignity caused by the demeaning conditions of the Versailles Treaty. As an alternative to the degeneration they perceived in Weimar society, and

47 Puschner, Die völkische Bewegung, p. 264.

48 Mosse, The Crisis of German Ideology, p. I.

49 Hermand, Der alte Traum, pp. I2-15 and passim. 
to artistic modernism in particular, völkisch-nationalists continued to promote the idea of an organic social order, the Volksgemeinschaft (community of the Volk), which can be traced back to the German Romantics. ${ }^{50}$ Far from calling for a return of the monarchy, they called for a new leader, a Führer, who would bring the rebirth of German society. Believing that the true expression of the German spirit was threatened by the spread of literary modernism and political republicanism, they also engaged with the emerging NSDAP.

Chapter 2 considers National Socialism in a völkisch context both before and after 1933. It turns to those in charge of propaganda and the cultural sphere and addresses völkisch responses to the institutional climate established in the Third Reich against the backdrop of rivalry for domination of the cultural sphere between Joseph Goebbels and Alfred Rosenberg. Here the rudimentary nature of Nazi politics of literature becomes clear. When the Second World War broke out, the institutions concerned with literature were still defining their roles. As Jan-Pieter Barbian has demonstrated, there was never a cohesive Literaturpolitik in the Third Reich. ${ }^{51}$ A lack of institutional transparency, as well as rivalries and personal differences among leading Nazis led to frequent conflicts. The relationship between völkisch-nationalist writers and the institutions that governed the literary sphere, moreover, was tense at best. While the Nazis needed these writers to provide the regime with literary representation, a significant number refused to subjugate themselves and their work to the propaganda apparatus. The networks, formal and informal, that grew up between these writers were significant; they not only provided a forum for their ideas but also a framework for communication, mutual endorsement and activity independent of the regime in the Third Reich. Their treatment in this

See, for example: Umut Özkirimli, Theories of Nationalism. A Critical Introduction (Basingstoke: Macmillan, 2000), pp. 15-19, 52-53; E. Kedourie, Nationalism (4th edition: Oxford: Blackwell I994), p. I; Jost Hermand, Der alte Traum vom neuen Reich, pp. II-I2; Detlev W. Schumann, 'Gedanken zu Hofmannsthals Begriff der “Konservativen Revolution”', pp. 856-858.

5 I Jan-Pieter Barbian, Literaturpolitik im 'Dritten Reich': Institutionen, Betätigungsfelder (Frankfurt am Main: Buchhändler-Vereinigung, 1993). 
chapter, therefore, provides the context for the examination of the authors' history during the Third Reich in the chapters that follow.

Chapter 3 focuses on the transformation of the Literature Section in the Prussian Academy of Arts into the German Literature Academy and its impotence in the Third Reich. It charts the divisions between writers with political ambitions and more idealistic völkisch-nationalists. Demonstrating the increasing dissatisfaction of the latter with the position of the Academy, it argues that, while outwardly powerless, the institution actually provided them with a context for contact and communication, enabling them to share their disaffection. Its failure generated considerable antipathy to the Nazi regime among völkisch-nationalists. This was manifested most immediately in the 'Munich Consensus', a bloc of six writers that developed in the Academy and became the basis for an informal network of independent nationalists in the literary world in the 1930s. This group consisted of Hans Grimm, Erwin Guido Kolbenheyer, Rudolf G. Binding, Börries Freiherr von Münchhausen, Wilhelm Schäfer and Emil Strauß.

The ways in which völkisch-nationalist independence was maintained outside the framework of the German Literature Academy are the subject of Chapter 4. The activities in völkisch literary circles described here helped sustain völkisch-nationalist networks in the Third Reich. Particular attention is therefore paid to Hans Grimm's Lippoldsberger Dichtertreffen, held at the writer's home each year between 1934 and 1939, and again each year after 1949, and to the history during the Third Reich of the most significant völkischnationalist publisher in Germany, the Langen-Müller Verlag in Munich. Its unsuccessful struggle for independence in these years mirrors that of völkischnationalists in general to establish themselves as a separate estate in German society. The journal Das innere Reich provides a further example of a forum through which the writers in question sought to communicate their ideas to a wider public. The examinations of contributions to Das Innere Reich carried out by Horst Denkler in 1976 and Marion Mallmann in 1978 highlight the difficulties scholars have had in assessing the literature of the Third Reich. ${ }^{52}$

52 Horst Denkler, 'Janusköpfig. Zur ideologischen Physiognomie der Zeitschrift “Das innere Reich” (1934-1944)', in Denkler and Prümm (eds), Die deutsche Literatur 
This chapter places the journal in the völkisch-nationalist context. The difficulties experienced by Das innere Reich in the late 1930 s only came to an end with the solution presented by the Second World War. After 1939, its editors were increasingly able to reconcile their goals with those of the Nazis through support for the war, viewed as a fight to the death that would end either in a glorious resolution of the evils that had plagued German society since 1918 , or final defeat for Germany.

The determination among völkisch-nationalist writers to promote the idea of a racially defined Germany continued to motivate their activities after the Second World War, when they increasingly linked it to the idea of a united Europe with Germany at its centre. Chapter 5 therefore examines the post-war era in the late 1940 s and 1950 s. Contrary to the anti-fascist rhetoric in the socialist East, in West Germany the cultural change that accompanied the establishment of a liberal, democratic West German state after 1945 was initially accompanied by an ambiguous approach to the Nazi past. Many Germans resisted the cultural transition initiated by the Allied occupation powers. Over a hundred significant nationalist parties, groups and cultural organisations emerged between 1945 and 1960. For their members the völkisch-nationalist message of racial and national rebirth offered cultural orientation in the face of physical and political dislocation and social upheaval.

Following the Second World War, a number of völkisch-nationalist writers who had been prominent in the Third Reich were able to revive their careers. Hans Sarkowicz estimates that only one-sixth of the recipients of literary prizes, honours and awards under the supervision of Goebbels' Reich Chamber of Literature published nothing at all after the War. ${ }^{53}$ Chapter 5 therefore also addresses the contribution made by völkisch-nationalist writers to the survival and development of German nationalism in West Germany after 1945. Analysing the political and social conditions

im Dritten Reich, pp. 382-405; Marion Mallmann, 'Das innere Reich': Analyse einer konservativen Kulturzeitschrift im Dritten Reich (Bonn: Bouvier, 1978).

53 Hans Sarkowicz, 'Die literarischen Apologeten des Dritten Reiches zur Rezeption der vom Nationalsozialismus geförderten Autoren nach 1945', in Thunecke (ed.), Leid der Worte, p. 436. 
in which they were able to achieve success in the 1950s, it assesses the extent to which they contributed to the formation of Germany's post-war identity. In particular, it focuses on the surviving members of the "Munich Consensus': Hans Grimm, Erwin Guido Kolbenheyer, Wilhelm Schäfer and Emil Strauß. Using the works, correspondence and articles in the press written by this group of writers, this chapter discusses their attempts to deny a share in responsibility for Nazi crimes by emphasising that Nazism did not represent true German nationalism. It demonstrates how they sought to revive a nationalist ideology as the basis for the new Germany, and juxtaposes these efforts with their attempts to relativise the history of the Third Reich. In this way, this chapter offers a perspective on the way in which nationalism in Germany was affected by the legacy of the Third Reich and the nature of right-wing thought between 1945 and 1960. 



\section{'Wegbereiter' for the Nazis? Völkisch-Nationalist Writers in Germany, I870-1933}

The identifiable characteristics of völkisch-nationalist ideology were responses to changes in Germany between 1870 and I9I4. The Kaiserreich saw the rapid growth of industrial capitalism and dramatic urbanisation, leading to social upheaval that appeared to threaten traditional ways of life. Between 1890 and 1913 , the population grew from 49.4 million to 66.9 million, making it the second largest in Europe after Russia. In the three decades after 1866, 2.9 million Germans emigrated in response to economic challenges at home. During the boom years after 1893 , however, the flood of emigrants decreased. Instead, large numbers migrated from rural areas to the expanding industrial cities within Germany. Between I870 and I910, the number of cities with populations over 100,000 rose from 8 to 48 . By 1914, one fifth of the population lived in the cities. ${ }^{1}$ While the state's structures continued to defend the historic privileges of the landowners, the growth of capital and industry led to a diminished economic role for agriculture. The growing bourgeoisie increasingly demanded equality with the aristocratic classes. At the same time, the new challenge of organised labour emerged, following the abolition of the Anti-Socialist Law in 1890 and the resulting growth of the Social Democratic Party, which emphasised class conflict and demanded radical reform. ${ }^{2}$ Völkischnationalism emerged as an extreme, but nonetheless increasingly widely accepted, integrative ideological programme for a bourgeoisie that felt it

I Völkier Ullrich, Die nervöse Großmacht, I87I-I9I8. Aufstieg und Untergang des deutschen Kaiserreichs (Frankfurt am Main: Fischer, 1999), p. 138. 
was sandwiched between the powerful landed interests on the one hand, and organised labour on the other.

Völkisch writers played a central role in the codification and dissemination of völkisch-nationalism, making literature fundamental in the fight against the evils of the contemporary world. Their works reflected the atmosphere of change and the tension between progress and tradition. While they privileged the countryside over the growing cities, which they saw as responsible for the degeneration of the German Volk as a result of bad living conditions and immoral behaviour, ${ }^{3}$ they did not reject industrialism outright. Nonetheless industry was rarely presented as central to the ideal society. ${ }^{4}$ From its emergence as a primarily bourgeois response to conditions in the Kaiserreich, völkisch-nationalism increasingly sought to gain the support of the entire German nation. This corresponded to its ideological emphasis on a social order in which race rather than class was the defining category. While there was general acceptance of certain core elements, völkisch-nationalism remained broad. By the outbreak of the First World War its underlying characteristics were identifiable in a large number of social and political positions. These featured a common recognition of the degeneration of modern life and opposition to socialism, Bolshevism, international capitalism, and not infrequently the Jews. A shared utopian vision of a Volksgemeinschaft, a socially, politically and spiritually united community of the German Volk, defined by blood, and an assertion of an eternal, absolute and organic truth accompanied a rejection of the aesthetic modernism observable in the artistic avant-garde of the early twentieth century. This, with its international characteristics, seemed to threaten the process of cultural unification. Many völkisch-nationalists also supported German colonial ambitions. As a rule, too, they disapproved of parliamentary systems, advocating instead a form of government based on und Notwendigkeiten (Leipzig: Dieterich, 1912).pp. 168-170; This is also reflected in Hans Grimm's later work, Volk ohne Raum (Munich: Langen-Müller Verlag, 1926). See, for example, Paul de Lagarde, Schriften für das deutsche Volk (Munich: Deutsche Buchgemeinschaft, 1934), vol. I, p. 35. Also Uwe Puschner, Die völkische Bewegung im wilhelminischen Kaiserreich, p. I55. 
the so-called Führerprinzip, according to which a leader would emerge out of the Volk, recognisable through the great deeds he (the Führer was always referred to in the masculine) had performed.

The large number of organisations, some very short-lived, that came under the völkisch umbrella during these years is testament to the disunited and inconsistent nature of the phenomenon. Rather than a political movement, völkisch-nationalism is therefore best understood as a mode of thought based on an understanding of society based on the German race. Its incoherent manifestations were already evident even to those involved in völkisch-nationalist activities before the First World War. ${ }^{5}$ Overall, the goal of völkisch-nationalism was the renewal and rebirth of Germany. It developed and matured in the Kaiserreich, when the nationalist right moved from co-operation with the government to representing nationalist opposition to Wilhelmine politics. This prepared it, to an extent, for the challenges it faced after 1918, when völkisch-nationalists identified themselves in opposition to the Weimar Republic. Even then, however, they failed to achieve the unity that many viewed as essential for success.

\section{The 'Jewish Question'}

The relationship between the völkisch ideology and German anti-Semitism in the late nineteenth and first decades of the twentieth centuries was close but complicated. While some völkisch-nationalists expressed an extreme, targeted antipathy towards the Jews in particular, for others the question of race as a whole was more important. In their attitudes towards the Jews, völkisch-nationalists owed much to the development of German anti-Semitism during the nineteenth century, when it underwent a transformation from religious anti-Semitism to racial anti-Semitism. This change accompanied the debate concerning the assimilation of the Jews, which also 
exposed the depth to which anti-Jewish sentiment had penetrated German society. While liberal opinion tended to favour assimilation in the belief that Jewish characteristics were not biological, but lay instead in the Jewish tradition, racial anti-Semites emphasised biological differences between Germans and Jews. Jewishness was in the blood, thereby eliminating any hope of assimilation through the adoption of German customs and the Christian religion. ${ }^{6}$

In his novel Soll und Haben, first published in 1855 and reprinted 27 times in the following 23 years, Gustav Freytag demonstrated the degree to which stereotypes of Jews prevailed in German culture. With one exception the Jewish characters in this novel were unattractive, money-oriented figures. They also spoke grammatically incorrect German, suggesting that it was not their native tongue and setting them apart from the Germans. ${ }^{7}$ These stereotypes had their roots in older views of Jewishness. ${ }^{8}$ It was frequently alleged that Jews predominated in certain trades and professions, largely in non-productive spheres, and that in artistic life their abilities lay in interpretation rather than creation. Following the emancipation of the Jews in Prussia in 1869 many abandoned Jewish orthodoxy. Between 1889 and 1910 there were 12,375 Jewish conversions to Protestant Christianity in Germany, and this figure does not take into account those Jews who were assimilated before this date.'

Freytag's novel allowed for the possibility of Jewish assimilation to German culture in the figure of Bernhard, whose concern for high culture reflected the civilised character ascribed to Germans. ${ }^{10}$ In an essay published

6 Peter Pulzer, The Rise of Political Anti-Semitism in Germany and Austria (New York: Harvard University Press, 1964), p. 5.

7 Gustav Freytag, Soll und Haben (Edition used: Munich: Droemersche Verlagsanstalt Knaur, 1959).

8 Hannah Arendt, The Origins of Totalitarianism (New York: Harcourt Brace, 1973), p. xi.

9 Pulzer, The Rise of Political Anti-Semitism, p. 5.

Io On the debate about Freytag's attitudes towards the Jews, see Jürgen Matoni, 'Die Juden in Gustav Freytags Werken', Oberschlesisches Jahrbuch, vol. 8 (Berlin 1985), pp. 107-116. See also: Martin Gubser, Literarischer Antisemtismus: Untersuchungen zu Gustav Freytag und anderen bürgerlichen Schriftstellern des Ig. Jahrbunderts (Göttingen: Wallstein, 1998); Hartmut Steinecke, 'Gustav Freytag: Soll und Haben 
in the Viennese Neue Freie Presse on 2ist May 1893, moreover, Freytag spoke out directly against racial anti-Semitism's denial of the possibility of assimilation. Writing for the celebration of Pentecost, Freytag reminded his readers that the Apostles had themselves been Jews. He went on to criticise the racial anti-Semites,

for they scour the family trees of Christians back to some distant past and declare conversion to Christianity and the assimilation of baptised Jews into Christian family life to be dishonest and a blemish on the offspring of such mixed marriages. This view holds both a lack of German convictions and an inclination towards usurious business dealings to be indelible characteristics of Jewish descent, which continue to have an effect in later generations, even under totally different circumstances, and when they have converted to Christianity. ${ }^{11}$

Racial anti-Semites did indeed express reservations regarding assimilation. In spite of his initial support for Freytag's view in its favour, Heinrich von Treitschke, Professor of History in Berlin, increasingly expressed concern that should it fail, it would breed a bastard German-Jewish culture. Treitschke's belief in assimilation of the Jews as a realistic solution to the 'Jewish question' waned towards the end of the nineteenth century. His emphasis on the Jew as an alien was famously expressed in a series of articles published in the Preußische Jahrbücher between 1879 and $188 \mathrm{I} .{ }^{12}$ The first, Unsere Aussichten, unleashed the Berliner Antisemitismusstreit, in which Treitschke was vigourously opposed by his colleague at the university in Berlin, Theodor Mommsen. Drawing widespread attention through his publications, as well as his lectures, Treitschke helped make anti-Semitism the subject of respectable, intellectual debate. ${ }^{13}$

(1855). Weltbild und Wirkung eines deutschen Bestsellers' in Horst Denkler (ed.), Romane und Erzählungen des Bürgerlichen Realismus: Neue Interpretationen (Stuttgart: Reclam, 1980), pp. 138-152.

II Gustav Freytag, 'Über den Antisemitismus. Eine Pfingsbetrachtung', Neue Freie Presse, Vienna, 21.051893.

I2 Heinrich von Treitschke, 'Unsere Aussichten', Preußische Jahrbücher, November I879.

I3 Significant contributions from both sides of the Antisemitismusstreit are reproduced in Karsten Krieger (ed.), Der 'Berliner Antisemitismusstreit' I879-I88I: Kommentierte Quellenedition (Munich: Saur, 2003); see also: Walter Boehlich (ed.), Der Berliner 
The importance of race for anti-Semites in Germany was most unambiguously articulated by Wilhelm Marr, credited with inventing the term 'anti-Semitism'. In his book, Der Sieg des Judentums über das Germanentum (1879), ${ }^{14}$ he presented a socio-cultural history of the development of Jewish hegemony in the world. He moved the fight against Judaism from the religious to the racial field, thereby removing anti-Semitism from the charge of religious prejudice and aligning it with social-Darwinist theories. ${ }^{15}$ In 1880 he summed up his position: 'There must be no question here of parading religious prejudices when it is a question of race and when the difference lies in the "blood"' ${ }^{16}$ Marr opened the way for the association of anti-Semitism with racial discussions of morals and culture that were central to völkischnationalist discourses by the end of the nineteenth century.

Houston Stewart Chamberlain, Richard Wagner's son-in-law, also provides an example of the far-reaching impact of anti-Semitic writers in the late nineteenth century. ${ }^{17}$ His most influential work, Die Grundlagen des neunzehnten Jahrhunderts (I899) was characterised by irrational antiSemitic polemics and Chamberlain's passion for culture and the ideal of self-cultivation. ${ }^{18}$ The work presented the history of mankind as a struggle

Antisemitismusstreit (Frankfurt am Main: Insel-Verlag, 1965), especially pp. 237-263; Peter Pulzer, Jews and the German State: The Political History of a Minority, I848-1933 (Oxford: Blackwell, 1992), pp. 96-97; George Mosse, The Crisis of German Ideology, pp. 200-20I. Treitschke's best-known historical work was Deutsche Geschichte im neunzehnten Jahrhundert (5 Volumes, Leipzig: Hirzel, I878-I894).

I4 Wilhelm Marr, Der Sieg des Judentums über das Germanentum (Bern: Costenoble, I879).

I5 Moshe Zimmermann, Wilhelm Marr, The Patriarch of Anti-Semitism (Oxford: Oxford University Press, 1986), p. 79.

I6 Quoted in Pulzer, The Rise of Political Anti-Semitism, p. 50.

17 Mosse, The Crisis of German Ideology, p. 93; Joachim Kohler, Wagner's Hitler, pp. I30-I3I.

I8 Houston Stewart Chamberlain, Die Grundlagen des neunzehnten Jahrbunderts (1899). Among his other works were a number of biographies: Richard Wagner (Munich: Bruckmann, I895), Immanuel Kant. Die Persönlichkeit als Einführung in das Werk (Munich: Bruckmann, 1905), Goethe (Munich: Bruckmann, 1912). See also: Geoffrey G. Field, Evangelist of Race: The Germanic Vision of Houston Stewart Chamberlain (New York: Columbia University Press 198I), p. 224. 
between the good, embodied in the German race, and the bad, represented by the Jews. The influence of Grundlagen des neunzehnten Jabrhunderts went beyond nationalist organisations, attracting widespread attention in the press. On 30 th April 1902, the Frankfurter Zeitung was forced to admit reluctantly that it 'has caused more of a ferment than any other appearance in the book market in recent years. ${ }^{19}$ Three editions appeared in its first year and a cheap, popular edition, published in 1906, sold more than I0,000 copies in the first ten days. By I9I5, total editions exceeded I00,000 copies and the book had been translated into English, Czech, and French. ${ }^{20}$ It appears to have been read with enthusiasm by the Bildungsbürgertum in general, and even by Wilhelm II, who sent Chamberlain a note of appreciation in which he declared that the book had 'brought order to my confused thoughts and light into my darkness, and pointed out the paths that will lead to the salvation of the German nation and thereby of mankind itself.' ${ }^{21}$ He instructed that every Prussian school should have a copy in its library and recommended it as reading for army officers. ${ }^{22}$

\section{Adolf Bartels and Anti-Semitic Literary Criticism}

The success of Chamberlain's work is one example of the widespread acceptance of anti-Semitic views in 'polite' society. From the early I 880 s, discussions of the 'Jewish question' moved away from a focus on assimilation towards racial discourses in which the Jews were perceived not only as a foreign race, but a threatening 'counter race'. A desire for 'racial purity' drove the anti-Semitic discourse of the final decade of the nineteenth century and the first decade of the twentieth to new extremes. Likewise,

Field, Evangelist of Race, p. 225.

20 Ibid.

2I Quoted in Kohler, Wagner's Hitler, p. I25.

22 Ibid. p. I25. 
anti-Semitism influenced the development of völkisch-nationalism in these years as the two increasingly converged. ${ }^{23}$

At the turn of the century Adolf Bartels, an outspoken anti-Semite and literary critic, was instrumental in popularising the racial anti-Semitism of men like Marr and Chamberlain. He remained prominent until his death in 1945 . He published several novels and plays, but was best known for his literary criticism. As a literary critic Bartels was a man of his time. Fifty years earlier literary criticism was still bound to the universities. ${ }^{24}$ After I871, however, a change occurred in the literary sphere. Rapid industrialisation and the changes it brought to the German economy were accompanied by an explosion in the number of publishers, journals and newspapers responding to an increase in the size of the reading public and a corresponding growth in the demand for reading material. Books, journals and newspapers were no longer produced for an educated minority, but became commodities with a large market. ${ }^{25}$ Literary criticism gained a new readership among the middle classes. ${ }^{26}$ Literary critics increasingly expressed views that went beyond the works themselves, dealing with social and political issues. Bartels was one of the most extreme. In the 1890 os his work appeared in two journals, the political articles in Die Grenzboten and the literary in Ferdinand Avenarius' Der Kunstwart. In total he wrote over 300 articles for the latter until September 1906, after which his views became too extreme for even the conservative Avenarius. In these articles he popularised his favourite authors, including Friedrich Hebbel, Otto Ludwig and Wilhelm Raabe. $\mathrm{He}$ also began to define the problems he saw in German literature. Both

Werner Bergmann, 'Völkischer Antisemitismus', in Uwe Puschner, Walter Schmitz, Justus H. Ulbricht (eds), Handbuch zur 'Völkischen Bewegung' I87I-I9I8 (Munich: Saur, 1999), p. 456. Bergmann lists further völkisch-nationalist groups among those that represented this later, 'scientific' form of anti-Semitism: the Verein deutscher Studenten; the Deutsche Turnerbund; the DHV (see below); the Wartburgbund; and finally the Bund Alldeutschland.

24 Steven Nyole Fuller, The Nazis' Literary Grandfather: Adolf Bartels and Cultural Extremism, I87I-1945 (New York: Peter Lang, 1997), pp. 51-52.

25 Peter Fritsche, Reading Berlin (Cambridge MA: Harvard University Press, 1996).

26 Steven Nyole Fuller, The Nazis' Literary Grandfather, pp. 51-52. 
he and Avenarius used a metaphor of sickness when referring to the developments they saw in German culture at the turn of the twentieth century. Bartels labelled it 'modernitis.' ${ }^{27}$

As a literary critic, Bartels popularised 'race' as a critical category, an approach first introduced by Paul de Lagarde and Julius Langbehn in the second half of the nineteenth century. ${ }^{28}$ His most significant work was his Geschichte der deutschen Literatur, first published in 1901, and reappearing in a number of revised editions until $1945 .{ }^{29}$ Here he tried to cover the complete corpus of German literature. Half the work, however, is devoted to the nineteenth century. It combined his literary theories with his Geschichtsbild, which was firmly anti-modern. Bartels was the enemy of liberalism and Judaism, two of the forces of degeneration he saw and fought in society. He divided German literature into that written by Jews and that written by non-Jews and ignored criticisms that he was nationalistic. Nationalism was, in fact, something he deliberately cultivated and took very seriously. ${ }^{30}$

The Geschichte der deutschen Literatur was extremely successful, third and fourth editions being published by the Eduard Avenarius Verlag within two years of its appearance. His publisher also commissioned a third volume, the Handbuch zur Geschichte der deutschen Literatur, which was sold as a companion to the first two volumes. ${ }^{31}$ In addition a single volume Geschichte der deutschen Literatur sold almost 30,000 copies between 1919 and 1924. Bartels constantly revised this edition during the Weimar Republic until it was little more than a list of works divided into two categories: those that

27 Ibid. pp. 62-63.

28 See, for example, Julius Langbehn, Rembrandt als Erzieher (Leipzig: Hirschfeld, I890; edition used here: 1922); Thomas Neumann, Völkisch-nationale Hebbelrezeption: AdolfBartels und die Weimarer Nationalfestspiele (Bielefeld: Aisthesis-Verlag, 1997), pp. 39-40; Stern, The Politics of Cultural Despair.

29 Adolf Bartels, Geschichte der deutschen Literatur, 2 vols (Leipzig: Avenarius, 1901/1902).

30 Fuller, The Nazis' Literary Grandfather, pp. 70-71.

3I Adolf Bartels, Handbuch zur Geschichte der deutschen Literatur (Leipzig: Avenarius, 1906). 
supported the rebirth of the German people and those that, according to Bartels, were in league with the forces of liberalism and world Judaism. ${ }^{32}$

Bartels also used his reputation as a literary critic to contribute to anti-Semitic campaigns in Germany in the early twentieth century, not least his battle against the positive legacy of Heinrich Heine. On repeated occasions in the 1890 s, and again in 1906 , völkisch-nationalists mobilised to prevent the erection of a memorial to Heine, a Jew, in various German cities. In 1906, Bartels led the successful struggle against the unveiling of a statue in front of the city hall in Hamburg to commemorate the soth anniversary of Heine's death. On ist July, his 375-page book, Heine: Auch ein Denkmal, appeared, setting out his case against the poet. ${ }^{33}$ Bartels' complaint was that Heine was a Jew who claimed, or his supporters both during his lifetime and after his death claimed for him, a place in the ranks of the great German poets. He wrote:

$[\ldots]$ he $[$ Heine] is not a German lyricist; he is, as one must emphasize again and again, a Jew writing in German, who cannot de facto mean as much to us as even a smaller German talent whose poetry grows out of his life and being and, moreover, out of the German Volk. [...] Therefore the one-sided eroticist Heine cannot, by a long chalk, be to us what Hebbel and Mörike are. ${ }^{34}$

Bartels did not consider language sufficient to make a poet a member of the Volk. His racism was based on a theory of blood rather than culture.

Bartels' work aroused both positive and negative reactions. Among those who responded favourably was Ludwig Lorenz, who published a study of Bartels' works in 1908. Lorenz defended the anti-Semitic character of the Geschichte der deutschen Literatur, suggesting that it served to highlight the weaknesses in German literature in the early twentieth century. $\mathrm{He}$ defended Bartels' campaign against Heine:

I believe the influence of Jewish writers, who can basically never be completely German, is today actually too great and damaging in various ways. [...] If a spirited

32 Fuller, The Nazis' Literary Grandfather, pp. 70-71.

33 Adolf Bartels, Heinrich Heine: Auch ein Denkmal (Dresden: Koch, 1906).

34 Ibid. p. 284. Quoted in Fuller, The Nazis' Literary Grandfather, p. 120. 
campaigner has become angry about the state of literature today, I find it very understandable. Incidentally I would like to point out that Bartels is just as hard on Richard Voß, Bierbaum, Hartleben and others as he is on Jewish talents. In any case it is not permissible to reject his aesthetic judgements on account of his anti-Semitism. Even Jews, if they reflect carefully, have to recognise this. ${ }^{35}$

Like other apologists for Bartels, Lorenz saw his subject's self-imposed role as a national fighter as a strength; the importance of his literary works lay in their representation of their author's love for his homeland, an example to all Germans. ${ }^{36}$

The second significant achievement of Bartels' career was the establishment of the National Theatre Festival for German Youth and its parent organisation, the German Schillerbund. His crusade to bring school children from across Germany to Weimar to see productions of German classics began in 1905, and was combined with his desire to create a national theatre in Germany. In a pamphlet published the same year, entitled Das Weimarische Hoftheater als Nationalbühne für die deutsche Jugend: Eine Denkschrift, ${ }^{37}$ he argued that from the mid-nineteenth century German theatres had relied too heavily on foreign dramatists to provide them with their repertoire, allowing the non-German Geist to gain a hold. Bartels called for the renewal of the German theatre through the foundation of a German national theatre and the staging of festivals for school pupils, which would ensure that the seed of the German Geist was planted in the next generation. ${ }^{38}$ The timely opening of a new theatre in Weimar in 1908 presented Bartels with an opportunity to bring his plans to fruition. This was further helped by the appointment of Carl von Schirach, one of his strongest supporters and the father of Baldur, the future leader of the Hitler Youth, as its managing director. ${ }^{39}$ I908), p. 100. 36 Ibid. pp. IOI-IO3.

Ludwig Lorenz, Adolf Bartels und seine Dichtungen: Eine Studie (Dresden: Koch,

7 Adolf Bartels, Das Weimarische Hoftheater als Nationalbühne für die deutsche Jugend: Eine Denkschrift (Weimar: Böhlau, 1905).

Fuller, The Nazis' Literary Grandfather, pp. 89-90.

Ibid., pp. 89-90. Bartels was also Baldur von Schirach's tutor in these years. 
The German Schillerbund was founded at the first Nationalbühnentag on 30 th September 1906 with 60 members, largely writers, artists and teachers. The following year an Anruf was issued calling for support for the theatre festival. ${ }^{40} \mathrm{With}$ the influential support of several prominent literary figures behind it, it was possible to stage the first festival from 6th to 24 th July 1909. Two thousand students were given the opportunity to see Schiller's Wilhelm Tell, Lessing's Minna von Barnhelm, Kleist's Prinz von Homburg and Goethe's Egmont. The first festival was such a success that it subsequently became a biennial fixture in the German cultural calendar. Thereafter, however, the Schillerbund distanced itself from its creator, removing Bartels from its governing body in 1913 . He finally resigned altogether in $1915 .{ }^{41}$

\section{The City versus the Country}

While many völkisch-nationalists were anti-Semites, anti-Semitism was not the defining characteristic of völkisch-nationalism. Instead it was a consequential element of a general racist ideology. As Puschner points out, as the nineteenth century drew to a close a number of völkisch-nationalists were increasingly concerned that their ideology should not be identified as purely anti-Semitic. ${ }^{42}$ While this does not detract from their ideological debt to anti-Semitism, their primary concern was to promote an emphasis on the rebirth of the German Volk. The goal of the Volksgemeinschaft dominated their programme. In an article in the pan-German journal Das zwanzigste Jahrbundert in 1893 Friedrich Lienhard argued that the 'Jewish question' would solve itself if the prerequisites for a healthy life for the German Volk were met. He therefore wrote that anti-Semitism was not a social, moral or even religious question;

40 Neumann, Völkisch-nationale Hebbelrezeption, p. Iо2.

4I Ibid., pp. I21; I25.

42 Puschner, Die völkische Bewegung, pp. 15-16. 
it was 'not a question in its own right', but instead 'a negative part of a positive programme. And this positive programme is: Renewal of German culture in the German Geist and out of our German nature! This principled emphasis of Germanness is not chauvinism; it is a new principle. ${ }^{43}$ Lienhard advocated cleansing the German Volk of damaging foreign influences, which included liberalism, social democracy, French culture, and cosmopolitanism. These were to be replaced with a return to traditional German culture. ${ }^{44}$

Both Lienhard and Bartels were also among the founders of the Heimatkunstbewegung, a movement concerned with the literature and art depicting the life of provincial Germans in non-urban settings, and with the customs, traditions and history of the regions. ${ }^{45}$ It provided a channel for the expression of racial views that did not directly engage with the 'Jewish question'. Many of its representatives passively accepted the anti-Semitic views of writers like Bartels, but did not make them the centre of their world view. Bartels' contribution to the Heimatkunstbewegung included a collection of novels about his Schleswig-Holstein homeland. Among them was his volume of childhood memories, Kinderland, and the 500-page novel, Die Dithmarscher, chronicling three generations of a Dithmarschen family between 1500 and I559, and focusing on the ultimately unsuccessful struggle for independence waged by the Dithmarscher against the Danes and Holsteiner in the sixteenth century. ${ }^{46}$ It presents their cause as a heroic fight of the Volk against those forces that found their ultimate victory in the liberal culture of the industrial state. ${ }^{47}$

Concentrated in particular in border regions, the Heimatkunstbewegung promoted provincial life and traditions as the foundations of German society. It was inextricably linked to the völkisch movement and a precursor

43 Quoted in Puschner, Die völkische Bewegung, p. 55.

44 Ibid., p. 55 .

45 Fuller, The Nazis Literary Grandfather, pp. 25-31, 83-84.

46 Adolf Bartels, Kinderland: Erinnerungen aus Hebbels Heimat (2nd edition: Leipzig: Bürger, 1914) Die Dithmarscher: Historischer Roman in 4 Büchern (Kiel \& Leipzig: Lipsius \& Tischer, 1898 ).

47 See also Uwe-Karsten Ketelsen, Völkisch-nationale und nationalsozialistische Literatur, p. 38 . 
to the Blut und Boden literature promoted by the Nazis thirty years later. Kay Dohnke points out that völkisch literature developed beyond the provincial focus of the Heimatkunstbewegung, nationalist perspectives superseding local patriotism; nonetheless the roots of both movements were too multiple and can be traced too far back to make a simple progression from Heimat to völkisch movement convincing. ${ }^{48}$ A largely middle class phenomenon, the Heimatkunstbewegung was at once an assertion of local patriotism and an expression of nationalist sentiment. It was a conscious celebration of regional differences within the national whole; 'Germanness' was embedded in the history and customs of Germany's many regions, whence it derived its strength. ${ }^{49}$ The Heimatkunstbewegung therefore shared many of the characteristics identified by Celia Applegate as belonging to the wider Heimat movement that also emerged in Germany at this time. Applegate asserts, however, that in promoting regional identities, the historical unions, walking clubs, Heimat museums and other organisations that contributed to the Heimat movement were not necessarily engaging in a political or social discourse, but at most in a community-building exercise. $^{50}$ The Heimatkunstbewegung, however, took the sentiments of regional romanticism and used them as the basis for a nationalist discourse based on the relationship of the Volk with its native landscape. ${ }^{51}$ This idea later influenced a number of leading Nazis, most notably Walter Darré. ${ }^{52}$ It was therefore inextricably linked to the völkisch ideology, which identified the

48 Kay Dohnke, 'Völkische Literatur und Heimatliteratur I870-1918' in Puschner et al. (eds), Handbuch zur 'Völkischen Bewegung' I87I-I9I8 (Munich: Saur, 1999), pp. 652-653.

49 Celia Applegate, A Nation of Provincials: The German Idea of Heimat (Berkeley: University of California Press, 1990), p. 80.

$50 \quad$ Ibid. pp. 3; 103-107.

5I The roots of this idea can be seen, for example, in the earlier works of Ernst Moritz Arnd and, particularly, Wilhelm Heinrich Riehl. See Colin Riordan, 'Green Ideas in Germany: A Historical Survey' in Colin Riordan (ed.), Green Thought in German Culture: Historical and Contemporary Perspectives (Cardiff: University of Wales Press, 1997), pp. 3-4I; on Arndt and Riehl, pp. 8-II.

52 Anna Bramwell's controversial political biography of Walter Darré seeks to rescue the reputation of its protagonist by arguing for the existence of a 'green' wing in the 
German Volk as the descendent of the Germanic tribes, each rooted in a different region. The migration of these tribes led to a mixing of their blood, and the creation of the German Volk. Regional identification, epitomised by identification with the native landscape, was a sign of relating to the Germanic tribes of old, and demonstrated a deep feeling for the ancient roots of the modern Volk.

The Austrian literary historian Josef Nadler adopted these ideas as the basis for his literary theories, focusing his work on a version of the history of the German tribes adapted from the work of his teacher, August Sauer, Professor of German in Prague. Sauer approached every text as a product of a particular tribe, from which a writer inherited his or her most primitive cultural influences. ${ }^{53}$ Nadler adopted a more sophisticated argument that suggested that the tribe was one important element among a range of influences on a writer. According to Nadler, the individual belonged to the family, which in turn belonged to a tribe, which, under the right circumstances, belonged to a racially defined state. ${ }^{54}$ The development of the literature of the different tribes was, moreover, dependent on their native landscapes. The literature of the Saxons was, for example, informed by the River Elbe and wide northern vistas, making them the guardians of the Nordic myths and sagas; the Franconians, with the Rhine running through their country, were the tribe of German poetry. ${ }^{55} \mathrm{~W}$ ith his history of German literature, the first volume of which was published in 1912 as the Literaturgeschichte der deutschen Stämme und Landschaften, Nadler felt he had given German literary scholars a new national direction. Through the historical development of the tribes to form the German Volk, he tied

NSDAP: Blood and Soil: Richard Walther Darré and Hitler's 'Green Party' (Bourne End: Kensal, 1985).

53 Sebastian Meissl, 'Zur Wiener Neugermanistik der dreißiger Jahre: Stamm, Volk, Rasse, Reich. Über Josef Nadlers literaturwissenschaftliche Position,' in Klaus Amann and Albert Berger (eds), Österreichische Literatur der dreißiger Jahre (Vienna: Böhlau, I985), p. 133 .

54 Ibid.pp. 133-134.

55 Josef Nadler, Literaturgeschichte der deutschen Stämme und Landschaften 4 vols (Regensburg: Habbel, I912-1928), vol. I, pp. 6-7. 
the Volk firmly to the land. As a result, true German literature, formed by the relationship of the writer to his or her tribal landscape, and representing the völkisch spirit, expressed a very deep relationship with the ancient roots of the German people.

The Heimatkunstbewegung was also part of the reaction against urbanisation in the Kaiserreich. Its attitude towards capitalism was marked by the experience of 1873 , when Germany's industry and financial markets were hit by a crisis from which the middle class only slowly recovered. ${ }^{56}$ The migration of people to the cities coupled with falling educational standards, were also seen by concerned völkisch commentators as promoting social democracy. The sinking birth rate in the cities was viewed in eugenic terms, presenting the danger of racial degeneration and an increase in deformity, especially among the poor. Industrialisation had lured many people away from the land with the promise of easy earnings and greater freedom. Morally the removal of large numbers of people from their natural habitats was seen not only to spur materialism, and wild behaviour, but also to prevent the growth of any feeling of belonging. The long-term result would be a Volk torn from its roots. The city was therefore seen as the fundamental antithesis to the integral relationship between the Volk and its landscape, against which Heimat writers propagated an idyllic vision of country life and the peasant as the bedrock of German society. ${ }^{57}$

Heimat literature, including works produced by advocates of the Heimatkunstbewegung, offered city dwellers a temporary escape from their environment and a connection to a set of local customs and history older than the cities in which they lived. Against modern society, it sought to provide an antidote to the alienation of its inhabitants. ${ }^{58}$ The rejection of urban society and the idealisation of rural life in Heimat and

56 Karl-Heinz Rossbacher, 'Programm und Roman der Heimatkunstbewegung Möglichkeiten sozialgeschichtlicher und soziologischer Analyse' in Viktor Žmegač (ed.), Deutsche Literatur um die Jahrhundertwende (Königstein/Ts.: Verlagsgruppe Athenäum, Hain, Scriptor, Hanstein, 198I), p. 127.

57 Claß, Wenn ich Kaiser wär', pp. 20-26.

58 Applegate, $A$ Nation of Provincials, pp. 70-74. 
völkisch literature referred back to nineteenth century village tales, ${ }^{59}$ and formed a representational basis for the interlocked ideologies of the Heimatkunstbewegung and the völkisch movement. Journals like Der Türmer (1898), Heimat (1900), Die Rheinlande (1900), as well as Die Gesellschaft provided a forum for the pastoral image of rural life. ${ }^{60}$

The works of the Heimatkunstbewegung reflected the paradoxical nature of völkisch-nationalism as whole. It was a bourgeois protest against bourgeois society, providing both an explanation of and an answer to a sense of crisis in German society. The Heimatkunstbewegung presented the völkisch-nationalist vision of rural life as the antidote to capitalist materialism, the rise of Social-Democracy, and the misery of the industrial cities. Numerous organisations were also established to enable city dwellers to live out the romantic idealism it provided. The Wandervogel, for example, was founded in Berlin to provide young people with the opportunity to hike in the German countryside, thereby obtaining the necessary relationship with their native landscape. ${ }^{61}$ The popularity of such organisations served to endorse further the idea of Heimat in the völkisch-nationalist imagination as the negation of everything encompassed by the term 'Berlin'. Materialism was confronted with idealism in an attempt to raise German cultural life to a higher spiritual level.

Condemning the cold rationalism of the naturalist realism they opposed as the product of the Enlightenment, völkisch-nationalists drew a distinction between proof and instinct. The latter was represented in their literature by the peasant hero, a man of deeds not words, whose knowledge was based on life not books. Examples of such heroes include Harm Wulf in Hermann Löns' Der Wehrwolf and Jörn Uhl in Gustav Frenssen's work of that name. ${ }^{62}$ These protagonists were shown them in tune with their native lands, from which they drew strength in the face of

59 Rossbacher, 'Programm und Roman der Heimatkunstbewegung', p. I23.

60 Stern, The Politics of Cultural Despair, p. 98.

6I Walter Lacqueur, Die deutsche Jugendbewegung (Cologne: Verlag Wissenschaft und Politik, 1978).

62 Gustav Frenssen, Jörn Uhl; Hermann Löns, Der Wehrwolf(Jena: Diederichs, I9I2). 
the difficulties presented by the modern world. ${ }^{63}$ Rootedness and belonging are the necessary foundations for life in these novels, and are to be found in the native community in its landscape. As such these ideas were easily combined with völkisch-nationalist definitions of the Volksgemeinschaft. This belonging was not materialist, but had a metaphysical quality; the spiritual, moral and physical health of the German Volk were intrinsically connected.

\section{Gustav Frenssen}

As Adolf Bartels was one of the founders of the Heimatkunstbewegung, so Gustav Frenssen was one of its most successful representatives. The bestselling author in Germany in the years 1905 and 1906, Frenssen, like Bartels, contributed to making völkisch-nationalist ideas part of mainstream literary culture in Germany between 1900 and 1914. In 1913, the total copies printed of his colonial novel, Peter Moors Fahrt nach Südwest, numbered around 180,000 , while in $1916 \mathrm{Jörn} \mathrm{Uhl}$ reached close to 240,000. Frenssen began his career as a pastor in Schleswig-Holstein. Three volumes of his sermons were published between 1899 and 1902 and by 1928 a total of 97,000 copies had been printed. ${ }^{64}$ During his years as a pastor, Frenssen not only developed his social and theological thought, but also began to develop an interest in biological and racist literature. In his memoirs, the Grübeleien, he described his desire to improve the health of human nature and society. ${ }^{65}$ The huge success of Jörn Ubl in I90 r enabled Frenssen to leave his career in the church in order to devote his energies to writing. During

63 Rossbacher, 'Programm und Roman der Heimatkunstbewegung', p. I23.

64 Dietrich Stein, 'Spuren im Nebelland. Fakten und Menschliches in Frenssens Biographie', in Kay Dohnke and Dietrich Stein (eds), Frenssen und seiner Zeit: Von der Massenliteratur im Kaiserreich zur Massenideologie im NS-Staat (Heide: Boyens, 1997), pp. 23-24.

65 Ibid. p. 24. 
the years that followed he wrote one of his few dramas, Das Heimatsfest, and the novel Hilligenlei ${ }^{66}$ Hilligenlei was concerned with the anger of the bourgeois youth, and the possibility of a better, more völkisch religion. Frenssen challenged bourgeois morality, particularly regarding sexuality, and promoted behaviour based on biological-racial considerations. Overall, he adopted a strongly chauvinist and racist version of the völkisch ideology, which also included criticism of institutional Christianity. ${ }^{67}$ A pure, German belief system was needed that would, he argued, reunite nature and religion.

A year after Hilligenlei, Frenssen published the novel Peter Moors Fahrt nach Südwest and 100,000 copies of each novel had been printed by November in their respective years of publication. Both demonstrate the themes running through Frenssen's ideological thinking at this time, themes that continued to influence his work. Peter Moors Fahrt nach Südwest, Frenssen's contribution to colonial literature, dealt with the campaign to put down the Herero Uprising in German Southwest Africa between 1904 and 1907. Here, Frenssen demonstrated his concern for Germany's position in the world alongside the other great powers. Racial relationships are also considered in the book. ${ }^{68}$ The words of the Oberleutnant in the final pages reflect Frenssen's own social-Darwinist views:

'These blacks have deserved death before God and humanity, not because they have murdered two hundred farmers and risen up against us, but because they have built no houses and dug no wells.' [...] 'What we sang in the service the day before yesterday: "We come to pray before God the just", I understand as follows: God gave us victory because we are nobler and strive harder. That does not say much in relation to this black people; we must ensure that we become the best and the most watchful of all peoples on Earth. The world belongs to the industrious, the brightest. That is God's justice. ${ }^{69}$

66 Gustav Frenssen, Das Heimatsfest: Schauspiel in 5 Akten (Berlin: Grote, 1903); Hilligenlei (Berlin: Grote, 1905; 1937 edition also consulted).

67 Stein, 'Spuren im Nebelland', pp. 3 I-33.

68 See for example: Frenssen, Peter Moors Fahrt nach Südwest: Ein Feldzugsbericht (Berlin: Grote, 1942), pp. 68-69.

69 Ibid. p. 196. 
One thousand copies of the work were distributed by the Central Office of the Navy League, Germany's largest nationalist organisation, as propaganda for the nationalist, colonial cause in the 1907 Reichstag elections. The Navy League's propaganda efforts were undertaken in close coordination with Chancellor Bülow's office, which also informally provided the funds for this undertaking. ${ }^{70}$ Frenssen's work was, therefore, not only widely received by the German public at large, but also by the political establishment. The appeal of his novels lay in the fact that he addressed themes current to his readership. His position at the heart of German literary life demonstrates his place in the mainstream of the early twentieth century. This was due to the successful combination of völkisch mysticism and more straightforward political nationalism, which did not threaten the establishment, in which he had many friends. Frenssen's nationalism, his support for German colonialism, his call for a more Germanic Christianity and a return to values based in the Volk and nature all found a resonance not only among völkisch-nationalist reformers, but also among the German bourgeoisie. ${ }^{71}$

The breadth of his correspondence also attests to his wide appeal. He exchanged letters with Hermann Hesse and other liberal writers, as well as with nationalists like Börries von Munchhausen. ${ }^{72}$ Around the time when he was writing Peter Moors Fahrt nach Südwest, Frenssen was also in contact with Hans Grimm, who was living in South Africa. Through Grimm, Frenssen accessed experience of Germany's colonies. Grimm's son, Wernt, later remembered visits to Frenssen's home in Blankenese with his parents during the First World War, when he was a small child. ${ }^{73}$ The contacts between the

\section{Eley, Reshaping the German Right, pp. 255-256.}

Stein, 'Spuren im Nebelland', p. 32.

Ibid.

Wernt Grimm added a note to Grimm's archive, in which he recalled these visits. See: DLA - A: Grimm, Grimm to Gustav Frenssen, 1902-1928. That such visits took place is confirmed in the correspondence between Grimm und Frenssen. For example a postcard from Frenssen of I8.8.1915 requests the arrival details of Grimm in Blankenese: Postcard from Frenssen to Grimm, Blankenese, 18.4.1915. Also postcard, 4.7.1917. Other postcards exchanged between the Grimm and Frenssen families also illustrate the visits between them took place during the war, DLA - A: Grimm, Frenssen to Grimm, 1902-1928. 
two writers occurred on a level of personal friendship that extended to their families. Frenssen also encouraged Grimm in his early literary endeavours, complimenting him on his amusing style in a postcard in $1914,{ }^{74}$ presumably after having read one of his two works published in 1913: Südafrikanische Novellen or Afrikafahrt-West. Ein Reisebuch und Einfübrungsbuch. ${ }^{75}$ Given Frenssen's proven interest in African affairs and his personal friendship with Grimm, it is likely he was acquainted with these works.

The personal nature of such acquaintanceships contributed to the creation of strong networks among writers of a völkisch-nationalist persuasion. These survived periods in which they found themselves faced first with the challenges of the Weimar Republic and then with the attempts of Goebbels and the Nazi regime to break down these networks and replace them with their own. Nonetheless, not all the contacts between völkischnationalist writers were cordial. Frenssen was also acquainted with Adolf Bartels. The latter was born a year before Frenssen and their attendance at the Gymnasium in Meldorf, Schleswig-Holstein, overlapped between I 877 and I879. From the beginning of his literary career, Frenssen received negative criticism from Bartels. On the appearance of Frenssen's second novel, Die drei Getreuen, Bartels reviewed his work in the Literarisches Centralblatt, in which he described it as typical of trivial literature written for women. ${ }^{76}$ Frenssen, dissatisfied with Bartels' judgement, wrote him a long letter on 28 th November 1898 , in which he defended his writing in a long discussion of the worth of the Schriftsteller opposed to that of the Dichter. ${ }^{77}$ Frenssen identified himself in the tradition of the Dichter, aligning

74 Postcard from Frenssen to Grimm, I.6.1914 in DLA - A: Grimm, Frenssen to Grimm, 1902-1926. The envelope is addressed to Grimm at Beethovenstr. 9, BahrenfeldAltona, where he lived while he studied at the Colonial Institute in Hamburg.

75 Hans Grimm, Südafrikanische Novellen (Frankfurt a/M: Rütten \& Löning, 1913); Afrikafahrt-West: Ein Reisebuch und Einführungsbuch (Frankfurt a/M: Rütten \& Löning, 1913).

76 Thomas Neumann, “'Deine Ausführungen hättest Du Dir sparen können ... ” Einige biographische Anmerkungen zum Verhältnis Adolf Bartels - Gustav Frenssen' in Dohnke and Stein (eds), Gustav Frenssen in seiner Zeit, p. 348.

77 The full text of Frenssen's letter is reproduced by Neumann in " Deine Ausführungen hättest Du Dir sparen können ... "', p. 349. 
himself with names in German literature such as Goethe and Keller rather than fellow Heimatkünstler like Lienhard and Bartels. ${ }^{78}$ Nevertheless, he suggests that the name of Schriftsteller would be satisfactory to him if it was also applied to Gustav Freytag, Peter Rosegger and Charles Dickens. The debate about the definition and relative worth of Dichter versus Schriftsteller was one that would continue throughout the first half of the twentieth century, particularly in völkisch literary circles. ${ }^{79}$ The animosity between Frenssen and Bartels, who had much in common, both ideologically and biographically, did not abate in the course of their later careers.

Gustav Frenssen's völkisch-nationalist worldview was rooted in his relationship with his Schleswig-Holstein Heimat and his religious views, which increasingly tended towards the brand of völkisch mysticism he demonstrated in Hilligenlei. His concept of the Volk was bound up with social-Darwinism, and in particular the idea of the survival of the fittest, as he demonstrated in Peter Moors Fahrtnach Südwest. Before the First World War, he differentiated between different Völker, but for most of his career he did not nurture a particularly negative view of the Jews, in contrast with Adolf Bartels. For Frenssen a racist worldview did not automatically mean anti-Semitism; racial differences also existed between the Germans and the Anglo-Saxons, the Turks, the Romanians and so on. Indeed, Crystall suggests that Frenssen consciously rejected the anti-Semitic sentiments that existed in the church circles from which he came. Furthermore, during the First World War, he made several positive comparisons between the Germans and the Jews in his propagandistic journalism for the German cause. ${ }^{80}$ At this stage, therefore, for Frenssen the Jews were a separate race,

78 Uwe K. Ketelsen, 'Frenssens Werk und die deutsche Literatur der ersten Jahrzehnte unseres Jahrhunderts. Zuordnungen, Parallelen, Abgrenzungen,' in Dohnke and Stein (eds), Gustav Frenssen in seiner Zeit, p. 155.

79 See, for example, Hans Wysling (ed.), Dichter oder Schriftsteller? Der Briefwechsel zwischen Thomas Mann and Josef Ponten, I919-1930 (Bern: Francke, 1988).

80 See, for example, Gustav Frenssen, 'Um Haus und Herd' in Deutsche Kriegswochenschau, No. 15, 18.3.1917, quoted in Andreas Crystall, Gustav Frenssen: Sein Weg vom Kulturprotestantismus zum Nationalsozialismus (Gütersloh: Gütersloher Verlagshaus, 2002), p. 403, n.424. 
but not necessarily inferior. From about 1927, however, with the publication of the second volume of his Grübeleien, a change can be observed in his attitudes. From this point, Crystall argues, in years of diminishing success, Frenssen increasingly demonstrated the overtly negative attitude towards the Jews that was to characterise his position in old age after 1933. Influenced by his publisher, Müller-Grote, he blamed his lack of success in the I920s on the unhealthy impact of Jewish internationalism on German culture. ${ }^{81}$

\section{Völkisch Organisations and the Printed Word}

The term völkisch was first applied in Germany at the beginning of the twentieth century to denote a reform movement in which ethnicity was the decisive category. ${ }^{82}$ Nevertheless, as we have seen, völkisch ideas were already evident in the second half of the nineteenth century. ${ }^{83}$ Like-minded men of a volkisch persuasion formed groups dedicated to the propagation and dissemination of their Weltanschauung. The organisations that emerged provided their members with access to discussion and active involvement in politics. Moreover, organisations often had members in common, creating an intricate web of groups that between them covered a broad spectrum of patriotic interests. As Roger Chickering has argued, these links opened up any organisation, even choral societies, to politicisation. ${ }^{84} \mathrm{~W}$ ith memberships exceeding those of the political parties, nationalist groups represented an enormously influential form of political mobilisation, particularly among middle-class Germans. According to Eley, they increasingly represented an extra-parliamentary alternative to established political parties in the

81 Crystall, Gustav Frenssen, pp. 399-400.

82 Puschner, Die völkische Bewegung, p. I4.

83 Stern, The Politics of Cultural Despair, pp. 3-4.

84 Roger Chickering, We Men who feelmost German: A Cultural Study of the Pan-German League, I886-I9I4 (Boston: Allen \& Unwin, I984). p. I84. 
Reichstag. He suggests that from the start they resulted from dissatisfaction with the formal government of the Kaiserreich. ${ }^{85}$

While they were not necessarily founded on völkisch-nationalist principles, a number of right-wing organisations increasingly came to represent völkisch views, contributing to their dissemination as well as reflecting their acceptance in mainstream German culture and politics. Chickering's study of the Alldeutscher Verband shows how this organisation's ideology developed in a volkisch direction prior to the First World War. Among the most significant organisations to emerge in the final decade of the nineteenth century, it was founded in 1890 and reached its highest point with about 23,000 members around 1900 . While it was not the largest nationalist movement of the time, it was one of the most active. Its chairman from 1893 until 1908 was Ernst Hasse, professor of statistics in Leipzig and a member of the Reichstag. Hasse's successor in 1908 was Heinrich Claß, under whose leadership the organisation gained a clearly anti-Semitic character.

The Alldeutscher Verband did not start life with an overtly racial ideological programme. By the end of the nineteenth century, however, its leaders had adopted a clearly völkisch agenda. This conclusion is drawn by Puschner in the light of the organisation's identification of itself, 'as the purest embodiment of the nationalist cause, standing above the political parties and their conflicts, the supreme co-ordinator of individual nationalist campaigns. ${ }^{386}$ Chickering also demonstrates the centrality of a völkisch world-view to the Alldeutscher Verband, which viewed its responsibilities and actions as fundamental for ensuring that the definition and defence of the national interest remained in the hands of the Volk itself. ${ }^{87}$ Operating beyond the formal, political institutions in Germany, it drew its strength from its membership in a network of local branches, an example of völkisch political activity that drew authority from the people rather than from political systems or institutions.

86 Quoted by Eley, Reshaping the German Right, p. 48; see also Puschner, Die völkische Bewegung, p. 69.

87 Chickering, We Men who feel most German, p. 45. 
The programme of the Alldeutscher Verband was founded on an expansionist and social-Darwinist ideology that emphasised the superiority of the German Volk. Wilhelmine colonial and naval policies were too mild for Hasse and $\mathrm{Cla}$, who campaigned for the implementation of radical imperial policies. A strong German empire was proposed as an answer to the emigration of Germans from the Reich. The situation of the Auslandsdeutsche was also a major concern for the members of the Alldeutscher Verband, which increasingly led its members to advocate the territorial expansion of Germany within Europe as well as Africa. ${ }^{88}$ In addition, the Verband's opposition to the German government's policy of neutrality during the Boer War gained it enormous attention and an upsurge in membership at the beginning of the twentieth century. Not only were fifty new chapters added to the existing 157 as a result of its rallies, but over 200,000 Marks were raised in the six months following the announcement of a 'Boer Collection' in October I899. By 1902 half a million Marks had been raised, which were used for charitable purposes in support of the Boers, underlining the anti-British attitudes of the League. ${ }^{89}$

Domestically the Alldeutscher Verband also demanded stronger measures against the enemies of the Reich.$^{90}$ These included Jews, liberals, Social Democrats, and Germany's neighbours on all sides. ${ }^{91}$ While its influence declined somewhat as a result of Chancellor von Bülow's efforts to discredit it after 1900 , a reaction to its efforts to upset the balance of his diplomacy towards Austria and Britain, the Alldeutscher Verband remained a significant extra-governmental force up to the First World War. ${ }^{92}$ Its contacts with the conservative parties, the nationalliberals, and the industrial, agrarian and middle-class interest groups intensified. ${ }^{93}$ In 1912 Heinrich Claß' book, Wenn ich Kaiser wär', was

88

Ibid. pp. 46-53.

Ibid., pp. 65-66.

Claß, Wenn ich Kaiser wär', p. 102.

Ullrich, Die nervöse Großmacht, p. $38 \mathrm{r}$.

Chickering, We Men who feel most German, pp. 63-69.

Hartmut Pogge von Strandmann, 'Staatsstreichpläne, Alldeutsche und Bethmann Hollweg' in Hartmut Pogge von Strandmann and Immanuel Geiss, Die Erforderlichkeit 
published under the pseudonym Daniel Frymann. ${ }^{94}$ In this work Claß outlined a range of perceived political and social problems and suggested far-reaching reforms designed to ensure political, social and racial health for Germany. Typically völkisch in its approach, it also addressed aesthetic questions, art being the fundamental expression of the German Volk. By 1914, the book had been through five editions, approximately 25,000 copies, and received positive reviews in the conservative and nationalliberal press. ${ }^{95}$ Although the Alldeutscher Verband did not officially adopt an anti-Semitic programme until after the First World War, from the turn of the century, influenced by Claß, many members embraced racial anti-Semitism as a way of galvanising sinking morale in the organisation. This brought the organisation into contact with other anti-Semitic activists and its journal, the Alldeutsche Blätter, became an organ for anti-Semitic discussion. ${ }^{96}$

During the Kaiserreich, the Alldeutscher Verband also developed close ties with a slightly different patriotic organisation: Friedrich Lange's Deutschbund. Founded in 1894 , the Deutschbund was intentionally elitist, with about 800 members by 1900 . Its constitution stated that 'The main aim of the Deutschbund lies not in words, and not solely in convictions, but in the application of both through work. ${ }^{97}$ This echoed the völkisch emphasis on action over intellectual pursuits. Nevertheless, paradoxically, the written word became a significant weapon in the struggle to disseminate this anti-intellectual ideology. The Deutschbund was antiSemitic and sought to promote the German Geist and identity through 'comprehensive educational and propagandistic work' in the broadest circles of the German Volk. ${ }^{98}$ It also promoted racial research and worked

des Unmöglichen: Deutschland am Vorabend des ersten Weltkrieges (Frankfurt a/M:

Europäische Verlagsanstalt, I965), pp. II-3I.

94 Claß, Wenn ich Kaiser wär'.

95 Ullrich, Die nervöse Großmacht, pp. 380-383.

96 Chickering, We Men who feel most German, pp. 234-245.

97 'Verfassung und Regeln des Deutschbundes', Forschungsstelle für Zeitgeschichte [FfZ], Hamburg, 42I-9: nationale und völkische Verbände.

98 Ibid. 
towards a universal application of racial policies in Germany's political, social and cultural life. ${ }^{99}$ As well as producing its own newsletter, the Deutschbundblätter, it maintained close links with the völkisch-nationalist Deutsche Zeitung. It was thus able to spread its ideology beyond its small number of members. ${ }^{100}$

The Alldeutscher Verband and the Deutschbund were two of many patriotic, nationalist and völkisch organisations that emerged in Germany in the late nineteenth century. Overlapping membership strengthened the ties between them. For example, the publisher Julius F. Lehmann was a prominent member of the Munich branch of the Alldeutscher Verband, and at the same time he was an active member of the Navy League. He and others like him provided a voice for the Alldeutscher Verband in the latter, larger and less extreme organisation. Overall, the relations between the two organisations were not clear-cut. In the Alldeutscher Verband under $\mathrm{Claß}$, there was never a clear decision on whether the Navy League should be regarded as a rival, or whether they should seek to use their influence in it to move it in their direction. ${ }^{101}$ In spite of such frictions, however, the landscape of nationalist organisations provided ample opportunity for völkisch-nationalism to gain a hold. A complex network of contacts, acquaintanceships and friendships emerged that increased völkischnationalist influence in many areas of German life.

During the First World War völkisch-nationalist groups and organisations prepared for Germany's victory. The unintended effect of their activities was to prepare them for the challenges of defeat. The war became more than a straightforward territorial conflict; Germany was engaged in a racial struggle against a diametrically opposite Weltanschaunng, in the form of the Jewish-dominated capitalism of Great Britain. ${ }^{102}$ Following Germany's defeat there was considerable concern among völkisch-nationalists regarding

99 Deutschbundblätter 28: Jahrgang Nr.53, 2.7.1913, FfZ, Hamburg, 412-9: nationale und völkische Verbände.

I00 Chickering, We Men who feel most German, p. 236.

IOI Ibid., pp. 60-62; I85-202; 256-257.

IO2 Quoted in Uwe Lohalm, Völkischer Radikalismus: Die Geschichte des Deutschvölkischen Schutz-und Trutz-Bundes, I919-1923 (Hamburg: Leibniz-Verlag, 1970), p. 47. 
Germany's future course. ${ }^{103}$ The Alldeutscher Verband turned to Heinrich Claß' book Wenn ich Kaiser wär for its post-war programme. ${ }^{104}$ The priority of its leaders during the revolutionary upheavals of 1918/19 was to hold the organisation together in order to assert their völkisch values in the face of revolution and an unwanted republic. Writing to the organisation's Judenausschuß on 25th November 1918, the anti-Semitic campaigner, journalist and writer, Alfred Roth recalled his original hope that war would bring the rebirth of the German Volk. He expressed disbelief regarding Germany's defeat, before asserting the role of the völkisch movement as a carrier of 'German' values at a time when they were threatened more than ever. Roth called on the existing groups and organisations to pool their resources to deal with the so-called 'Jewish question'. Only together, he asserted, would they thwart the Jewish threat, the strength of which was proved by the outcome of the war. ${ }^{105}$

At a conference in Bamberg in February 1919, the Alldeutscher Verband drew up a declaration against the Weimar Republic. This was the first comprehensive völkisch-nationalist programme to address Germany's situation following defeat and, on 28th August 1919, it was institutionalised in a new set of statutes. ${ }^{106}$ These declared the intention of the organisation to promote the united action of the entire German Volk. More specifically, it set out to rescue the German Volk and the German Reich from the threat posed by the 'collapse' of November 1918. This would be achieved through: I) the moral strengthening of all social classes, reawakening the characteristics of German heroes of old; 2) the restoration of a strong Kaiser; 3 ) the reinstitution of strong armed forces; 4) the re-conquering of the territories 'stolen' from Germany after the war; 5 ) the inclusion of Austria in the German Reich; 6) the provision of protection and help for Germans

I03 See for example, Dr. Richard Boschan, 'Die Zukunft unserer nationalen Vereine', Deutsche Zeitung, No. 420, 20th September 1919, p. 7.

I04 Lohalm, Völkischer Radikalismus, pp. I5-16

IO5 Letter from Alfred Roth, written on I5.II.1918 and sent to the members of the Ausschuß für die Judenfrage in the Alldeutsche Verband on 2.I2.1918. F.f.Z.: II,RI4-Nachlaß Alfred Roth.

I06 Lohalm, Völkischer Radikalismus, pp. 16-18. 
living beyond the borders of the Reich; 7) the formation and expansion of all areas in the lives of the Volk, state, and individual according to völkisch principles; 8) planned racial development of the German Volk through selective breeding and the promotion of particularly gifted Germans; 9) opposition to all forces that obstructed the development of or damaged the German Volk, in particular racial miscegenation and Jewish dominance of the political, economic and cultural spheres. ${ }^{107}$

Determined to make good its intention to become the 'stormtroop of völkisch thought', the Alldeutscher Verband also remained eager to maintain its previous emphasis on foreign policy. At the Bamberg Conference, it therefore formed a separate organisation that would concentrate on domestic politics, with the declared intention of fighting the liberal democracy of the Weimar Republic, and in particular leading the anti-Semitic struggle. ${ }^{108}$ The founders of the Deutschvölkischer Schutz-und Trutz-Bund (DVSTB) included Alfred Roth, Theodor Fritsch of the Reichshammerbund, Prof. Paul Langhans of the Deutschbund, Prof. Dr. Ferdinand Werner of the Deutschvölkische Partei and Adolf Bartels. ${ }^{109}$ They agreed that the degeneration of patriotic feeling and the corruption of German culture had led to Germany's defeat and subsequent political breakdown, a view also suggested by Moeller van den Bruck in his 1922 work, Das Dritte Reich. ${ }^{110}$ This corruption, according to the DVSTB, was the result of Jewish influence, which had to be combatted for the reconstruction of Germany to be successful. ${ }^{11}$

I07 Revised statutes of the Alldeutscher Verband 28.8.1919 in Hermann Sacher (ed.), Staatslexikon. Im Auftrag der Görres-Gesellschaft (sth revised edition, vol. I., Freiburg i.Br. 1926), pp. 126-131.

Io8 Lohalm, Völkischer Radikalismus, p. 77. The board (Beirat) of the Deutschvölkischer Schutz-und Trutz-Bund included many prominent names in völkisch circles: see the list at the end of Deutschland den Deutschen, undated pamphlet published by the Deutschvölkische Schutz- und Trutz-Bund in FFZ: Ir.R.I4-Alfred Roth (Nachlaß).

I09 Lohalm, Völkischer Radikalismus, pp. 18-20.

II Moeller van den Bruck, Das Dritte Reich (Hamburg: HAVA, I922; edition referred to here: 1931), pp. I-3.

II I Deutschland den Deutschen, undated pamphlet published by the Deutschvölkische Schutz- und Trutz-Bund in FfZ II, R.I4-Nachlaß Alfred Roth. 
The DVSTB embarked on a large-scale propaganda campaign, producing 7.6 million flyers, 4.8 million leaflets and 7.9 million badges in 1920 alone. ${ }^{112}$ It also organised conferences, demonstrations, public festivals, and marches, as well as producing more substantial works of literature. DVSTB propaganda had two purposes: it was designed to educate the organisation's members and to reach out to the public. Able to draw on the experience and backing of its Alldeutsch parent, the DVSTB operated effectively from the start. Following its amalgamation with the Deutschvölkischer Bund in the autumn of 1919 , it also published a weekly newspaper, the Deutschvölkische Blätter, which became the organisation's official publication, sent to all its members. In spite of its wide distribution, however, this paper failed to abandon its provincial character, and never gained the standing its editors hoped for. ${ }^{113}$

The DVSTB also published countless anti-Semitic brochures, tracts and books, ranging from pamphlets to more substantial works of a pseudoacademic nature. The former could be ordered in bulk for mass distribution. ${ }^{114}$ It also republished the anti-Semitic forgeries of the Talmud as well as the nineteenth-century Schulchan Aruch and supported the publication, by the Sleipner-Verlag in Hamburg, of the first new post-war edition of the standard anti-Semitic work, the Handbuch zur Judenfrage. ${ }^{115}$ The leaders of the DVSTB also contributed to the anti-Semitic canon themselves. Alfred Roth, under the pseudonym Otto Armin, was particularly prolific, producing works like Die Juden im Heere and Die Juden in den KriegsGesellschaften. ${ }^{116}$ In addition, the Hammer-Schläge series, published by the

I1 Lohalm, Völkischer Radikalismus, p. I23. Examples of Flugblätter by the DVSTB are available in FfZ: 4I2-I.

I13 Ibid., pp. I23-I24.

II 4 These included titles such as: Wissenswertes für die deutschblütige Jugend; Arbeiter, schüttelt das Judenjoch $a b$ and Der Anteil des Judentums am Zusammenbruch. See: Catalogue and order form for books produced or endorsed by the DVSTB, FfZ:412-I.

IIs Ibid.

II 6 Alfred Roth (Pseudonym Otto Armin), Die Juden im Heer (Hamburg: Hanseatische Verlagsanstalt, 1919); Die Juden in den Kriegsgesellschaften (Hamburg: Hanseatische Verlagsanstalt, 1920). 
DSVTB between I919 and I92I and largely written by DSVTB regulars like Alfred Roth and Adolf Bartels, dealt with current affairs. ${ }^{117}$ With a print run of I0,000 each, Lohalm estimates that each title reached more than 20,000 people. ${ }^{118}$ The organisation also endorsed a wide selection of more substantial anti-Semitic works, regularly reviewing new publications in the Deutschvölkische Blätter. They covered the usual range of anti-Semitic subjects: pseudo-scientific and semi-religious examinations of the Jewish race, discussions of cultural matters and debates about the 'success' and influence of the Jews. Both works of fiction and non-fiction were promoted. ${ }^{119}$

The Alldeutscher Verband was not the only organisation to recognise the importance of the printed word. The Deutschnationaler HandlungsgebilfenVerband (DHV), a union established in 1893 to champion the interests of the 2 million white-collar workers and clerks in the face of the growth of the Social Democratic Party, likewise promoted völkisch-nationalist literature. The DHV was based in Hamburg. By 1914, it had over 100,000 members across Germany and internationally. ${ }^{120}$ Like the DVSTB, its activities were twofold: it engaged in educating its members, and sought to spread its anti-Marxist, anti-egalitarian, and nationalist message more widely. The DHV charter excluded Jews. Its leaders encouraged members to blame their problems on the decline of German values resulting from the un-German capitalist system, introduced, they believed, by liberals, Marxists and Jews. In 1924, Hans Bechly, the DHV's director from 1909 to 1933, declared: 'We, the representatives of spiritual work in the German Volk, have the exalted task of forging the future of a new Germany. We have to play a spiritual leadership role for the working classes of the German Volk, and must remain constantly aware of this responsibility resting on our shoulders. ${ }^{121}$

II7 Catalogue and order form for books produced or endorsed by the DVSTB, FfZ:4I2-I

II8 Lohalm, Völkischer Radikalismus, p. I26.

II Catalogue and order form for books produced or endorsed by the DVSTB, FfZ:4I2-I

I20 Chickering, We Men who feel most German, p. 47.

I2I Quoted by Andreas Meyer, Die Verlagsfusion Langen-Müller: Zur Buchmarkt-und Kulturpolitik des Deutschnationalen Handlungsgehilfen-Verbands in der Endphase der Weimarer Republik (Frankfurt a/M: Buchhändler-Vereinigung, 1989), p. 9. 
The DHV programme embraced ideological, cultural and political affairs. As well as acquiring several publishing, printing and book distribution concerns, in I 893 its founders Friedrich Raab and Johannes Irwahn, both members of the anti-Semitic German Social Party, also set up a small printing house, which expanded to become the Hanseatische Verlagsanstalt (HAVA). Predominantly publishing anti-Semitic journals, this enterprise was initially independent of the DHV. It was nonetheless quickly contracted to print DHV materials, and soon became dependent on the trade union. By the end of the Weimar Republic, the HAVA had become one of Germany's leading völkisch-nationalist publishing houses, alongside the J.F. Lehmanns Verlag, the Diederichs-Verlag, and the HAVA's sister firm, the Langen-Müller Verlag.

During the First World War, the DHV actively disseminated nationalist literature. Its bookshop, established in 1904, concentrated on distributing volkisch works to soldiers in the field, and in 1916 a book club, the Deutsche Hausbücherei, ${ }^{122}$ was founded to ensure the distribution of German literature after the war. Its first board of directors, responsible not only for the club's business but also for selecting the works in its yearly lists, consisted of Hans Bechly, Albert Zimmermann, Max Habermann and Eugen Clauß from the DHV, as well as Adolf Bartels, Wilhelm Stapel, Johann Wilhelm Kinau (Gorch Fock), Richard Döring, Hans Clay, Christian Krauß, all prominent in the völkisch literary world. ${ }^{123}$

In November 1931 an article appeared in Herdefener, the Hausbücherei's magazine, recounting the club's history. It was, it declared, founded 'at a time when we still firmly believed in the victory of German arms', in order to ensure that when that moment came Germany would be freed of 'spiritual confusion. The same article went on to emphasise the importance of German literature:

for the German being exists in the German soul and this reveals itself in the work of German writers and thinkers! What German writers and thinkers, statesmen

I22 Initially the club was called the Deutschnationale Hausbücherei. It was changed to the Deutsche Hausbücherei after the First World War.

I23 'Wie die Deutsche Hausbücherei wurde', Herdefener, November 1931. FfZ: 522I-DHV. 
and leaders of the Volk have experienced, thought and written, what they have left behind for their Volk, their insights into the past and teachings for the future, are expressions of the German soul that flow out of our Volkstum. [...] If the danger of foreign infiltration and adulteration of our literature already existed before the War, a strengthened storm of foreign influences were inevitably going to set in after the War, even a victory [...]. It was necessary to fight this by selecting the best from the rich selection of good books of lasting value and the flood of new publications. ${ }^{124}$

The book club sought to make selected works accessible to a wide public, providing the völkisch education the DHV deemed necessary. The membership of the union provided a market for this enterprise, facilitating the production of inexpensive books for mass consumption. It was Germany's first significant nationalist book club. The first publications of the Deutsche Hausbücherei appeared in $1916 / 17$ and consisted of 17 titles; by 1933 the list included ${ }_{1} 9$ books. ${ }^{125}$ In order to make the Deutsche Hausbücherei accessible to all members of the German Volk, the monthly subscription was set at 2 RM. For this each member received 8 books a year and 6 copies of Herdefeuer, which claimed to take a critical stand on all areas of intellectual and cultural life and any significant new works of German literature. ${ }^{126}$

Advertisements for the Deutsche Hausbücherei exploited the changing social situation in Germany. Pamphlets such as Wille und Wegder deutschen Hausbücherei served a dual purpose. Stating that 'Germans can only be helped by Germans,' the book club stood against the subversion of German culture, customs and beliefs identified in the works of modern writers, which were the products of foreign influence. It recognised the need for pure, healthy German literature and free German writers as incorruptible mediators of German culture and spokespeople for the German Volksseele. It also stressed the need to promote those German writers and poets linked to their native soil and to free them from a book market dominated by big businesses. Finally, it echoed the earlier sentiments of Adolf Bartels in his campaign against the memorial to Heinrich Heine, declaring: 'Not every

I24 Ibid.

I25 For the complete annual lists of the Deutsche Hausbücherei between 1916/17 and I933 see FfZ: 522I-DHV.

I26 Pamphlet: Wille und Wegder Deutschen Hausbücherei in FfZ:5221-DHV. 
book written in German is a German book: not every writer writing in German is a German writer. ${ }^{127}$

Völkisch book clubs were aimed at the semi-educated lower middle classes, which was also the constituency in which the NSDAP was initially most at home. ${ }^{128}$ The suppliers saw them as a method of disseminating the German Geist and the völkisch ideology. For the consumers, ownership of books reflected social status, since they were identified with the respectable, educated bourgeoisie. Stark suggests that with the Deutsche Hausbücherei the DHV deliberately targeted white-collar workers who felt increasingly threatened by technical changes, greater rationalisation and concentration in industry, and feared sinking into the proletariat. ${ }^{129}$ It is likely that this was true for many members of the book club. Nonetheless, their number only became very significant between 1927 and 1929, years in which the Republic appeared to be consolidating itself, providing the financial stability needed for white collar workers to buy books. ${ }^{130}$

The history of the Deutsche Hausbücherei is illustrative of the strategies employed by völkisch-nationalists. Alongside the DHV's other publishing and book-selling enterprises, it emerged as one of several weapons in which

127 Ibid.

I28 Ketelsen, Literatur und Drittes Reich, pp. 300-30I; On class and National Socialism see also: Richard F. Hamilton, Who Voted for Hitler? (Princeton: Princeton University Press 1982).

I29 Stark, Entrepreneurs of Ideology, pp. 23-30.

I30 'Entwicklung der Deutschen Hausbücherei', handwritten notes taken from the file of Emil Schneider, FfZ: 522I-DHV; see also Stark, Entrepreneurs of Ideology, p. 30. German Home Library Subscriptions:

\begin{tabular}{|c|c|c|c|}
\hline Year & $\underline{\text { Members }}$ & Year & $\underline{\text { Members }}$ \\
\hline 1919 & 600 & 1926 & 6,458 \\
\hline 1920 & 880 & 1927 & 13,998 \\
\hline I92 I & $I, 200$ & I 929 (Jan) & 23,174 \\
\hline 1924 & 2,960 & I 929 (June) & 34,130 \\
\hline 1925 & 3,750 & I $930(\mathrm{Feb})$ & $40,25 \mathrm{I}$ \\
\hline
\end{tabular}


the union invested in order to disseminate völkisch-nationalist ideas. ${ }^{131}$ Following Germany's defeat in 1918, it increasingly allied itself with neoconservative and nationalist parties in the Weimar Republic, among them the NSDAP. In 1919 it also forged closer links with the League of Christian Unions and a new federation of public sector workers through the formation of the German Trade Union Federation (Deutscher Gewerkschaftsbund: DGB). While cooperation between the unions was based on common interest rather than shared ideology, this nonetheless provided further opportunities to reach a wide public. ${ }^{132}$ Concerned about its lack of influence in the Reichstag it also became increasingly involved in the political processes of the Republic, encouraging its members to support the DVP or DNVP in the elections in $1920 .{ }^{133}$ In the longer term it also consciously developed its influence over the German publishing industry in order to broaden its educational activities.

\section{The Emergence of the Langen-Müller Verlag}

As the DHV grew in importance and influence, it expanded its ownership of subsidiary organisations that were useful to its cause. It changed the face of the publishing industry in the Weimar Republic. As Stark notes, völkischnationalism was 'bound up with the internal history of the publishing industry in a way which other movements were not. [...] it was supported primarily by publicists and writers, rather than by organised political parties or institutions, and was thus more dependent than other movements on the printed word. ${ }^{34}$ Publishers performed an important function in mediating

I3I David Welch, The Third Reich: Politics and Propaganda (London: Routledge, 1993), pp. $5-8$.

132 William L. Patch Jnr., Christian Trade Unions in the Weimar Republic, 1918-1933: The Failure of 'Corporate Pluralism'(New Haven: Yale University Press, 1985), pp. 45-50.

133 Ibid. pp. 63-64.

134 Stark, Entrepreneurs of Ideology, p. Io. 
ideas in German society. Their role in the diffusion of völkisch-nationalist ideas was pivotal, and they often balanced economic demands with a völkisch-nationalist corporate ideology of their own. ${ }^{135}$ This last was sometimes the result of the convictions of the founders of publishing houses, as in the cases of the Eugen Diederichs Verlag in Jena, the J.F. Lehmann Verlag in Munich, and the DHV's Hanseatische Verlagsanstalt in Hamburg. ${ }^{136}$ In 1932, the DHV expanded its influence over völkisch-nationalist publishing by bringing together the Georg-Müller Verlag and the Albert-Langen Verlag, two well-established publishing concerns in Munich that had fallen on hard times, to create the Langen-Müller Verlag (LMV). This established a right-wing publisher in southern Germany that produced serious literature to rival more politically liberal firms in Berlin and elsewhere.

Albert Langen had founded his publishing house in 1893 and achieved considerable success in the first decade of the twentieth century, not least as the publisher of the liberal, satirical journal Simplicissimus. During the Weimar Republic, however, the Albert-Langen Verlag (ALV) increasingly promoted nationalist-leaning writers, among them new talent like Paul Alverdes, Karl Benno von Mechow and Hans Grimm. ${ }^{137}$ The history of the Georg-Müller Verlag (GMV) followed a similar course following its establishment in 1903. Under Müller, the house was characterised by an eclectic range of publications, and in particular the translations of the major classics in world literature. Before the First World War, it also produced the works of Franz Wedekind and August Strindberg, and published the early works of Robert Musil, Alfred Döblin, Lion Feuchtwanger, Leonhard Frank, Heinrich Mann,

I35 Ibid. p. 3.

I36 Eugen Diederichs, Der deutsche Buchhandel der Gegenwart in Selbstdarstellungen (Leipzig: Meiner, 1927; Justus Ulbricht and Mieke Werner (eds), Romantik, Revolution und Reform: Die Eugen Diederichs Verlag im Epochenkontext, 1900-1949 (Göttingen: Wallstein, 1999); Melanie Lehmann (ed.), Verleger J.F. Lehmann: Ein Leben im Kampffür Deutschland. Lebenslauf und Briefe (Munich: Lehmann, 1935); Siegfried Lokatis, 'Hanseatische Verlagsanstalt': Politisches Buch-Marketing im 'Dritten Reich'(Frankfurt a/M: Buchhändler-Vereinigung, 1992).

I37 Siegfried Jacoby, 'Der Weg des deutschen Buches: Verlagsort München', Berliner Tageblatt, 6.10.1928 in FfZ:36213: Verlagswesen, 1918-1933. 
Alfred Neumann and Jakob Wassermann. ${ }^{138}$ From the outset it targeted an educated readership. Following the founder's death in 1917, however, the Ullstein Verlag bought the rights to the classic works, and subsequently the Georg-Müller Verlag's bloom faded. Like the Albert-Langen Verlag, during the Weimar Republic it increasingly turned to nationalist literature, taking on the works of writers like Erwin Guido Kolbenheyer and Paul Ernst. ${ }^{139}$

Kolbenheyer was particularly important in the development of the Georg-Müller Verlag and its eventual amalgamation with the Albert-Langen Verlag. Born in 1878 in Budapest, he had already gained some attention for his historical novels before the First World War. ${ }^{100}$ Between 1917 and 1926 he produced the work for which he was best-known before 1945, the Paracelsus Trilogie. ${ }^{141}$ Looking back into Germany's history, his work identified the awakening of the German völkisch consciousness in the German mystics, a process that was fulfilled by the Reformation, in which the German Geist finally separated itself from Mediterranean thought and asserted its individual nature and character. He drew on the ideas of older völkisch thinkers to link his belief in a metaphysically defined Volk with the nationalist struggle of the I920s. ${ }^{142} \mathrm{He}$ was also a member of the selection committee for the Deutsche Hausbücherei, represented the völkisch right in the new Literature Section of the Prussian Academy of Arts, and was an early member of the Nazis' cultural organisation, the Kampfbund für deutsche Kultur. During his career, he was awarded no less than twelve literature prizes. ${ }^{143}$

${ }_{13} 8$ Werner Richter, 'Die literarische Diktatur der deutschnationalen Handlungsgehilfen', Berliner Tageblatt, 4.6.1931, in FfZ:5221: D.H.V.; Theodor Tiger, 'Georg Müller', Vossische Zeitung, I.I.1918, FfZ: 36213: Verlagswesen, 1918-1933; Siegfried Jacoby, 'Der Weg des deutschen Buches'.

I39 Mallmann, 'Das Innere Reich', pp. 4I-42; Meyer, Die Verlagsfusion, pp. 23-26.'

I40 For example: Erwin Guido Kolbenheyer, Amor Dei: Ein Spinoza Roman (Munich: Langen, 1908); Meister Joachim Pausewang (Munich: Langen, 1910).

I4I Erwin Guido Kolbenheyer, Die Kindheit von Paracelsus (Munich: Langen, 1917, edition consulted 1935); Das Gestirn von Paracelsus (Munich: Langen 1921, edition consulted 1935); Das dritte Reich des Paracelsus (Munich: Langen, 1925, edition consulted 1935).

I42 See also: Erwin Guido Kolbenheyer, Jagd ihn - ein Mensch (Munich: Langen I93I).

I43 Hans Sarkowicz and Alf Mentzer, Literatur in Nazi-Deutschland: Ein biografisches Lexikon (Hamburg: Europa-Verlag, 2000), pp. 24I-245. 
Kolbenheyer's involvement in the DHV's acquisition of the GMV demonstrates the influence of the firm's writers over its development in the Weimar Republic and Third Reich. In the years following the First World War the GMV struggled financially. Even after the inflation of the I920s had been brought under control, the failure of its directors to innovate in the face of changes in its readership led to its sale to the conservative Scherl newspaper empire in 1927. A year later, with debts of around two million Marks, another sale, this time to the Ullstein firm, appeared imminent. Kolbenheyer was, however, determined to prevent the loss of a major nationalist publisher to the liberal camp. Demonstrating the successful functioning of völkisch-nationalist networks, he appealed to Wilhelm Stapel, the editor of the HAVA journal Deutsches Volkstum, for help in orchestrating its takeover by the DHV. In February 1928 the DHV bought the failing publishing house for 700,000 Marks. ${ }^{144}$

For Kolbenheyer, at stake in these years was not simply the existence of the firm but a secure ideological foundation that would provide the institutional stability he desired for his work. In his eyes, this was intrinsic to the national interest, affecting him and also important fellow GMV writers, not least Wilhelm Schäfer and Paul Ernst. While Hugenburg's Scherl concern provided both financial security and nationalist values, Kolbenheyer suggested that it lacked the literary intuition and expertise needed for the production of serious works of German literature. Thus, writing after I945, he reflected the distaste of many völkisch writers towards the idea of becoming assets of a large, commercial concern. He desired a publishing house that combined influence over the book market with sensitivity to German nationalist culture. This ideal was achieved following the DHV's acquisition and amalgamation of the Müller and Langen houses, leaving an institution that operated relatively autonomously of its owners, under strong influence of the writers themselves. ${ }^{145}$

Kolbenheyer's post-I945 account suggests that the advantage of the DHV lay in the fact that, although it already possessed publishing and

144 Meyer, Die Verlagsfusion, p. 30.

I45 Kolbenheyer, Sebastian Karst, vol. III, pp. 9-10. 
printing interests, not least the HAVA, its main business was to represent its members professionally. Therefore, while its publishing activities were ideologically and commercially important to its directors, they were not the focus of its work. At the same time, its members provided a ready-made readership, and the works of a number of GMV and ALV authors were introduced to the Hausbücherei following the acquisition of the two firms. ${ }^{146}$ In addition, the success of Wilhelm Stapel's literary periodical, Deutsches Volkstum, in educated, intellectual circles and among academic youth was also testament to the potential for a literary publishing house within the DHV. According to Kolbenheyer, Stapel's publication was not only feared by those circles, 'which set out to determine the cultural-political development of the German Volk following the defeat in the First World War, ${ }^{147}$ but was also decisive in persuading the sober-minded businessmen of the DHV that further commercial ventures in literary publishing might be worthwhile. ${ }^{148}$ Thus, the acquisition of the two publishing houses combined, in Kolbenheyer's eyes, commercial and ideological considerations in a manner that exemplified the healthy organisation of such enterprises in an ideal völkisch-national order, based on social estates rather than classes or party political programmes. Seizing an opportunity to distance himself from the Nazi regime after 1945, in his memoirs Kolbenheyer also emphasised the connections of the DHV director Habermann with the Centre Party Chancellor, Heinrich Brüning, as well as the former's later death as a member of the resistance. Haberman, Kolbenheyer recalled, was the moving spirit in the decision of the DHV to purchase the Müller and Langen houses and their subsequent amalgamation in order 'to create a literary centre in the south of the Reich that would stand up to the literary firms of Berlin $[. ..]{ }^{1,49}$

The established reputation and lack of formal political allegiance of the GMV offered the DHV a clean slate on which to develop its goals. Under its ownership, from 1928 the avant-garde writers appearing under

I46 Siegfried Lokatis, Hanseatisches Verlagsanstalt, pp. I02-103.

I 47 Kolbenheyer, Sebastian Karst: Über sein Leben und über seine Zeit, 3 Vols (Gartenberg bei Wolfratshausen: 1955, 1957, 1958), vol. III, p. IO.

148 Ibid.

I 49 Ibid., p. II. 
the GMV imprint decreased in favour of those whose works demonstrated a strong tendency towards völkisch and Heimat themes. ${ }^{150}$ In the years that followed further authors, including Hans Franck, Friedrich Griese, Will Vesper, Richard Euringer and Heinz Steguweit, were transferred from the HAVA to the Munich firm as the latter became the flagship for the DHV's literary activities while the former concentrated more on factual works, particularly in the areas of law and economics. ${ }^{151}$

Making internal restructuring of the firm a condition for his continued association with it, Kolbenheyer was also instrumental in the appointment in September 1930 of Gustav Pezold, the owner of the Ossiander'sche bookshop in Tübingen, as the director of the Georg-Müller Verlag. ${ }^{152}$ A former submarine captain with proven right-wing and anti-Semitic credentials, Pezold was given almost complete autonomy. ${ }^{153}$ His vision corresponded closely to that of writers who gave the firm its character in these years. His aim was to construct a nationalist publishing house that would counterbalance liberal and Jewish firms like the S. Fischer Verlag in Frankfurt am Main and the Ullstein and Mosse publishing empires in Berlin. ${ }^{154}$

Kolbenheyer highlighted this as a motivating factor in his memoirs. He linked the Jewish backgrounds of the proprietors of the liberal firms to the dangers he believed they presented to German literature, suggesting that the strategic organisation of these firms, aided by their dominance over the press as well as book publishing, was designed and executed with considerable skill to support their degenerate cultural politics:

What one could call 'literature' and not just reading matter had largely fallen into intellectual and almost certainly material dependency on the Jews in Germany, to say nothing of Austria. [...] They [the liberal publishing houses] knew how to excite the

I50 Ibid. pp. 30-32.

I5I Lokatis, Hanseatische Verlagsanstalt, p. I03.

I52 Werner Richter 'Die literarische Diktatur der deutschnationalen Handlungsgehilfen', Berliner Tageblatt, 4.6.1931, FfZ 5221: D.H.V.

153 Lokatis, Hanseatische Verlagsanstalt, p. I03.

I54 Pezold later outlined his achievements in achieving this goal in a letter to Himmler, I4.I0.1936, DLA - Langen-Müller Verlag / Pezold. 
German reader, to entertain him without being heavy handed, to flatter his intellect, and tease his senses, they were readily available for intellectuals; their circulation was very wide. Important artists and scholars found support from them and knew what to do to secure their favour. They provided literary renown and determined what this meant, what could be designated 'literature'; such was the undisputed presumtuousness of these publishing corporations. They maintained and were guided by both unwritten and written 'black lists' of authors, on whom the Old-Testament bann was placed: 'He shall not be named!'155

For Kolbenheyer, the GMV under Pezold provided an opportunity to counteract these negative trends. ${ }^{156}$ It served to reverse the relative neglect he felt his own work suffered in the public sphere in the 1920s, in his view evidence of a deliberate attempt to silence him. This can be taken with a pinch of salt given his position in a number of significant organisations, including the Literature Section of the Prussian Academy of Arts. ${ }^{157}$ Elsewhere in his memoirs, moreover, Kolbenheyer suggested that his novels and stories had found a steady readership in the Weimar years. In addition, he maintained that success as a dramatist had forced him into the public spotlight, making him threatening to the left-liberal Jewish camp and highlighting his need for a secure publishing house base. ${ }^{158}$

In spite of significant financial subsidies from the DHV, Pezold quickly concluded that the firm would only be able to achieve its goals with the further acquisition of the ALV, which enjoyed a greater reputation and, more importantly, a more prestigious list of authors. Again, Kolbenheyer claimed a significant role for himself in bringing the second firm to the DHV. He was connected to ALV as well as the GMV in the r920s: while his fiction was based in the GMV, in 1923 he had published Die Baubütte, a theoretical work in which he outlined his biological social philosophy, with the ALV. He was, therefore, already acquainted with its two directors, Reinhold Geheeb and Korfiz Holm. In Kolbenheyer's eyes, the two men

I56 Ibid., pp. 389-390.

I57 See Chapter 3.

I5 8 Kolbenheyer, Sebastian Karst, vol. III, pp. 8-ıо. 
brought to what became the Langen-Müller Verlag (LMV) the literary knowledge and skills needed to complement Pezold's business instincts. ${ }^{159}$

Encouraged by Kolbenheyer and Stapel, therefore, in May 1931 the DHV acquired the ALV for 500,000 Marks. In March 1932, the two were merged to create the LMV. Pezold, able to draw on the extensive catalogues of both houses and with about 200 new titles each year, was now able to compete with the major liberal firms, establishing a centre for nationalist literature. ${ }^{160}$ Under Pezold, the Langen-Müller Verlag was largely autonomous in relation to its DHV owners, which further recommended the new firm to völkisch writers, later providing a context in the Third Reich, with mixed consequences, in which they sought to assert their right and obligation to regulate the German literary sphere themselves as the leading members of the creative estate.

The amalgamation of the two firms attracted considerable public attention. When the secretary of the GMV, Karl Krause, committed suicide shortly before the deal was finalised, the liberal Berliner Tageblatt suggested that his death was due to his unhappiness with the firm's new direction. It also asserted that the publishing house had sought to influence the ideological stance of its authors, misusing DHV money that would have been better spent helping union members severely affected by the depression. ${ }^{161}$

In response, the DHV asserted that its ideological programme demanded that the union concern itself not only with the material wellbeing of its members, of which there were 337,144 in $1931,{ }^{162}$ but also with ensuring that they were equipped to participate in the intellectual life of their Volk. ${ }^{163}$ Writing in the DHV's journal, the Deutsche Handels-Wacht, Wilhelm Stapel also clearly delineated the ideological lines that divided the German publishing industry. In building up the strength of its publishing

I59 Ibid., pp. 16-18.

I60 Stark, Entrepreneurs of Ideology, pp. 28-29.

I6I Richter, 'Die literarische Diktatur'.

I62 'Entwicklung des Mitgliederstandes des DHV, I893-1931. Rechenschaftsbericht erstattet von seiner Verwaltung', Hamburg 1931, FfZ 5221: DHV.

I63 A. Zimmermann, 'Rudolf Mosse gegen D.H.V., article in unnamed DHV publication, 1931, FfZ5221: DHV. 
concerns, he argued, the DHV did not need to hide its clear intention to develop an intellectual power. He continued:

It is generally well-known what sort of 'German Literature' is nurtured by the Berliner Tageblatt: Thomas Mann, Heinrich Mann, Klaus Mann, Ernst Gläser, Remarque, Lion Feuchtwanger, Stefan Zweig, Artur Schnitzler, Jakob Wassermann, Werfel, Toller etc. To what extent have we established a dictatorship over this literature? We are happy to leave to the B.T. the German literature about which it cares most. If, on the other hand, we espouse German literature that has partly been ignored by the B.T., partly grudgingly recognised, and, using techniques designed to debase it, invidiously torn apart - to what extent is that a dictatorship? The B.T. appears to know in its heart that its 'German literature' is not actually the real German literature. But in that case the circles surrounding the B.T. should have put their energies into serving true German literature sooner. Nonetheless, they have done nothing against the danger that the publishing rights of the most noble Scandinavian and German authors threatened to become a bankrupt's assets, from which any trader in literature could select those which appeared to promise the best returns for their business. Not the B.T., but the D.H.V. has rescued these writers from this situation. To us they were worthy of admiration and we responded to the duty their work laid upon us. ${ }^{164}$

The DHV thus positioned itself as the rescuer of German literature from the domination of the liberal publishing industry of the Weimar Republic, allegedly motivated only by profit.

\section{Hans Grimm and the Problem of Space}

Following the amalgamation of the Georg-Müller and Albert-Langen firms, Pezold needed to establish the new company both economically and ideologically in order to serve the political goals of the DHV. To do this, he drew on the existing reputations of the two houses and the support

I64 Wilhelm Stapel, "Literarische Diktatur" des D.H.V.?', Deutsche Handels-Wacht: Zeitschrift des Deutschnationalen Handlungsgehilfenverbandes, Gerwerkschaft der deutschen Kaufmannsgehilfen, No. 12, 38. Jahrgang, Hamburg 25.6.1931. 
of several prominent authors already on their books. The goodwill of the book trade was also necessary. In 1934 Pezold chose to build in particular on the success of Hans Grimm's Volk ohne Raum, first published in 1926 by the Albert-Langen Verlag. ${ }^{165}$ He resolved to publish a cheap edition of the novel, which had already sold 60,000 copies in an expensive twovolume edition. As a wave of so-called Volksausgaben began to appear on the book market, most notably Thomas Mann's Buddenbrooks, published by the S. Fischer Verlag, a cheap edition of Volk obne Raum was likely to receive a warm welcome. ${ }^{166}$

The peace of 1918/19 not only saw the loss of German territories in Europe, but also the end of German ambitions to found an empire elsewhere. Volk ohne Raum was the most (in)famous völkisch-nationalist work to tackle the issue of Germany as a world power, presenting her problems in terms of space and proposing colonial expansion as the solution. ${ }^{167}$ For Grimm, Germany's problems in the 1920 s were the outcome of centuries of misrule and the inability of Germans to recognise their own plight. Germany had missed the chance to expand in previous centuries. Grimm blamed this on the division of the German people, encouraged by other nations. He also maintained a fundamental belief in the superiority of the 'white race'.

Hans Grimm was born in Wiesbaden in 1875 to upper-middle class parents. On leaving school in 1896 , he went to London to train in business. A year later he departed for South Africa, where he remained for thirteen years. In Africa, he became convinced that Germany needed to expand her colonies in order to remain a great power. He also witnessed the Boer War and the German colonial campaigns, which profoundly influenced his writing and politics. His first work, the play Die Grobbelaars was published in Berlin in 1907, but gained little attention. ${ }^{168}$ On his return

165 Quoted in Meyer, Die Verlagsfusion, p. III.

166 Ibid. pp. III-II2.

I67 Hans Grimm, Volk ohne Raum (First published Munich: Langen, 1926; edition consulted: Lippoldsberg: Klosterhaus-Verlag, 1956).

I68 Hans Grimm, Die Grobbelaars: Ein Trauerspiel in vier Aufzügen (BerlinCharlottenburg: Vita Deutsches Verlagshaus, 1907). 
to Germany in I9Io he went to study politics, first in Munich and then at the Kolonialinstitut in Hamburg. In I913 he published Südafrikanische Novellen and Afrika-West. Ein Reisebuch und ein Einfübrungsbuch. These were followed in 1916 by Der Gang durch den Sand, which includes an account of South Africa's invasion of German Southwest Africa in 1914. ${ }^{169}$

From the beginning of his writing career, Grimm saw himself as a political writer. During the First World War he served briefly in the German artillery in Europe before he was moved to the Auslandsabteilung of the Oberste Heeresleitung. This office, funded by the Foreign Ministry, gathered intellectuals with expert knowledge of foreign countries together to examine the writings and letters of prisoners of war, and produce propaganda. Grimm was employed to write African stories that propagated the colonial ambitions of the German Reich. The result was the strongly nationalistic and anti-French Der Ölsucher von Duala, which documented alleged French atrocities during the conquest of Togoland. ${ }^{170}$

The Auslandsabteilung of the Oberste Heeresleitung was particularly significant in the development of völkisch-nationalist literary networks, forging networks that served the nationalist literary sphere during the Weimar Republic. Grimm's colleagues during this period included Börries Freiherr von Münchhausen and Arthur Moeller van den Bruck. Waldemar Bonsels and Friedrich Gundolf, professor of literature in Heidelberg, were also engaged by the bureau. After the War, Münchhausen and Grimm both became members of the Juniklub, an elitist organisation founded in 1919 and dominated by Moeller van den Bruck. For a relatively small organisation, the Juniklub disseminated its anti-republican message widely, thanks largely to its members' prolific production of articles for rightwing cultural journals. ${ }^{171}$ In their activities in the Juniklub, Grimm and

I69 Hans Grimm, Südafrikanische Novellen (Frankfurt a/M: Rütten \& Löning, 1913); Afrikafahrt-West: Ein Reisebuch und ein Einführungsbuch (Frankfurt a/M: Rütten \& Löning, 1913); Den Gang durch den Sand und andere Geschichten aus südafrikanischer Not (Munich: Langen, 1916).

I70 Hans Grimm, Der Ölsucher von Duala (Berlin: Ullstein, I918).

I7I On the significance of the Juniklub, and in particular its success in disseminating völkisch-nationalist thought, see Sontheimer, Antidemokratisches Denken, pp. 32-34. 
Münchhausen put themselves forward as members of the nationalist literary elite, striving for an authoritarian system of government in accordance with ideas propagated by völkisch theorists before the war. In the early I920s, they also made the acquaintance of Friedrich Lienhard, Erwin Guido Kolbenheyer, Wilhelm Schäfer, and Hans Friedrich Blunck, all of whom later played a significant role in the development of völkisch literary circles in the Third Reich.

The alienation of a people severed from their native soil was one of the fundamental concerns underlying völkisch ideology. Rapid population growth, combined with simultaneous industrialisation and urbanisation, continued to shape German consciousness into the 1920s and 1930 . Grimm's ongoing concern with this subject struck a chord. Volk obne Raum is set partly in Germany and partly in Africa and tells the story of the German, Cornelius Friebott, between 1887 and 1925. The book is divided into four parts, each narrating sections of the hero's life, and at the same time presenting specific political arguments. It demonstrates the perceived degeneration of German society and explores possible solutions, before settling on colonial expansion as the answer. In so doing, it also tracks the history of Germany's attempts to found a colonial empire in Africa, representing a lament for the German colonies lost during and after the war, developing themes that had occupied völkisch-nationalists before I9I4 and restating their relevance for the post-war period. Grimm's approach to writing novels like Volk obne Raum, which combined narrative fiction with the historical and political events of Germany's recent history, can be seen in his later correspondence with Gustav Pezold regarding a second epic work on German-British relations, on which he worked in the I930s and during the Second World War. Grimm first decided which events his heroes were to be involved in and then contrived ways to weave them into the life stories of his characters. ${ }^{172}$ Thus his readers were presented with novels that entertained with stories of adventure and at the same time 'educated' them in questions of politics and history.

I72 See, for example, Grimm to Pezold 24th June 1940, DLA - A: Grimm, Grimm to Pezold, 1938-1946. 
In common with fellow völkisch commentators, Grimm identified the forced migration of Germans to industrial cities as a cause of degeneration in Germany. Part One of Volk ohne Raum, entitled Heimat und Enge, demonstrated his belief that lack of space lay at the root of Germany's problems. The son of parents whose fortunes deteriorate in the early chapters of the story, Cornelius Friebott grows up in the Weser valley, where Grimm made his home from 1913. To supplement the living from his parents' insufficient smallholding, he trains as a carpenter. Failing to find work in his village, he tries various ways to earn money. A stint in the German navy and manual labour as a stone-cutter contribute to the formation of his early worldview, before he ends up working in a factory in Bochum. Grimm thus created an opportunity to portray the misery of Germany's industrial cities, and the alienation of the people cut off from the soil of their homes and the freedom offered by rural life rooted in traditions developed over generations. These linked the individual to the Volk through a shared past, present and future. A lack of land in Germany, however, made a return to this life at home impossible. Grimm therefore proposed colonial expansion to provide more land for the growing population, as it had for the British. Only as free men and women on German soil could the German Volk be great. ${ }^{173}$

Grimm also brought his hero into contact with Social Democracy. $\mathrm{He}$ thus addressed what he viewed as the failure of this ideology to provide solutions for the problems of the Weimar Republic. This, he suggested, was because it did not take the German völkisch identity into account. Friebott's involvement with Social Democracy, which was banned in Germany between 1878 and 1890 , ends in a prison sentence. Following his release he decides to leave Germany and try his luck in Africa. Part two, Fremder Raum und Irregang, describes Friebott's experiences in the British-ruled South African colonies. During this time, he learns that he will never find freedom in a land ruled by another Volk. After the Boer War, he lands in German South-West Africa, in time for the Herero Uprising. As the title of part three, Deutscher Raum suggests, he is on home territory here, in a land ruled by Germans for Germans. The vision of a German living and farming 
German soil grows and matures in Friebott's mind as the story unfolds, finding its fruition in a brief interlude of peace and prosperity before the colony is lost to the British. Following World War One, Friebott returns to Germany and in part four, Volk ohne Raum, he becomes an itinerant preacher of völkisch-nationalist colonialism, spreading Grimm's message of Volk ohne Raum across Germany, much as Grimm's writing was intended to do, and finally dying as a martyr to the cause.

For Grimm the German Heimat was where the German people lived independently, un-oppressed by foreign rulers. German soil could be anywhere, providing it was possessed, inhabited and cultivated by Germans. Colonial expansion, he argued, would not only provide space for Germans to establish themselves once more as a farming people, but also the necessary raw materials for German self-sufficiency, thus freeing the country from dependence on capitalist world markets. Like Frenssen, he justified colonialism on social-Darwinist grounds, arguing that a Volk that takes the territory of another is able to do so through its racial superiority and has therefore won the right to thrive at the expense of the weaker people. Building on the success of Volk ohne Raum, Grimm continued to campaign for the restoration of Germany's colonies throughout the Weimar period and into the Third Reich. In 1929 he published Das deutsche Südwester-Buch and in 1934 a collection of seven stories, Lüderitzland. ${ }^{174}$

Ketelsen suggests that Grimm's was not simply a nationalist message, in spite of the clear nationalism that characterised his works. He also suggests that Grimm's interest in Africa was not based on his personal biography, but on his fascination with the contrast between the African landscape and the Oberwesertal. ${ }^{175}$ This point of view seems overstated. The question of Germany's African colonies was not only one of enormous significance during Grimm's formative years, but also one he experienced first hand. Grimm's nationalism was formed by his years in Africa. Volk obne Raum addressed concerns that had occupied

174 Hans Grimm, Das deutsche Südwester-Buch (Munich: Langen, 1929; edition consulted 1937); Lüderitzland: Sieben Begebenheiten (Munich: Langen-Müller, 1934).

175 Ketelsen, Literatur und Drittes Reich, pp. 678-679. 
nationalists before 1914. It dealt with all the major völkisch themes. As a Kolonialroman, it advocated a strong colonial policy to deal with the perceived problems of overpopulation and urbanisation, and to restore the German nation to its rightful place in the world. As a Heimatroman, it emphasised the importance for Germans of the connection between the Volk and the land and expressed Grimm's concern about the deterioration of this relationship. Finally, it was infused with anti-socialism and profound anti-Semitism.

Grimm's portrayal of the Jews was based on a strong conviction of racial difference. It depended to a large extent on older stereotypes of the Jews as untrustworthy businessmen. Describing the trading of Jewish diamond merchants in Lüderitzbucht, Grimm suggested that they were deceitful dealers. He implied that, in the pay of the English, they made use of the fact that they had been born either in Germany, or to German-born parents, or in Russia, where they spoke Yiddish. As a result, he argued, they could not only understand and be understood by the German community, but their familiarity with German culture gave them an advantage in trade, which they exploited to the full. ${ }^{176}$ By reinforcing the impression that they were concerned only with making money - 'Where the Jew goes, money will be made ${ }^{177}$ - he explicitly built on the myth of the Jewish foundations of world capitalism.

For Grimm, Jewish capitalism was also represented by the British in Africa. The link between the British and Jewish business was a common one in völkisch-nationalist literature. Grimm's view of the British was ambiguous. On the one hand, he saw the British Empire as a positive example of the racial development of the Anglo-Saxons that should be emulated by the Germans; on the other, British capitalism was a sign of the degeneration of a Nordic race. Grimm admired the British for their imperial success, but at the same time, echoing Frenssen, he believed that the British were guilty of betraying the 'white race'. Capitalism and the hunger for power and wealth had overcome the deeper values of the British Volk. By contrast those of the

176 Grimm, Volk ohne Raum, pp. 853-855.

I77 Ibid. p. 855 . 
German Volk were upheld by German völkisch-nationalists. ${ }^{178}$ In Volk obne Raum, Friebott finds two worlds, that of the solid German farmer in the shape of the Boers, and that of the profit-oriented businessman represented by the English. For völkisch-nationalists during the Weimar Republic, Germany was still engaged in the struggle between German virtue and the mammonism of capitalism. ${ }^{179}$ In this, Grimm's work is another example of the continuity in völkisch-nationalism from the Kaiserreich to the Weimar Republic which provided an intellectual framework for his nationalism.

Following the publication of Volk ohne Raum in 1926, Grimm increasingly found himself on the cusp of literature and politics. Alongside his speeches, articles and political activities, his fictional work also addressed political issues more directly than that of many right-wing contemporaries, including Hermann Stehr, Emil Strauß, and Kolbenheyer. ${ }^{180} \mathrm{He}$ apparently experienced no conflict between his artistic and political ambitions. Unlike other politically conscious writers of his generation, for example Döblin or Brecht, he saw no need to analyse how these two goals should be integrated. ${ }^{181}$ The opening sentence of Volk ohne Raum left the reader in no doubt about Grimm's intention: 'This German tale is, in my opinion, a political tale and therefore illustrates our German fate. ${ }^{182}$

In spite of his ideological convictions, however, negotiations with Hans Grimm regarding a Volksausgabe of his epic proved less straightforward than Pezold hoped. Grimm demonstrated his businessman's credentials when it was suggested the cheap edition should be sold for the unusually high price of 8.50 RM; Thomas Mann's Buddenbrooks by

178 Hans Grimm, Englische Rede: Wie ich den Engländer sehe (Gütersloh: Bertelsmann, 1938).

179 See for example, Grimm, Volk ohne Raum, pp. I89, 439-440, 50I; see also Schoeps, Literatur im Dritten Reich, pp. 74-75.

I80 Bodo Heimann, 'Die Konvergenz der Einzelgänger: Literatur als Integration des problematischen Individuums in die Volksgemeinschaft: Hermann Stehr - Emil Strauß - Erwin Guido Kolbenheyer' in Denkler and Prumm (eds), Die deutsche Literatur im Dritten Reich, p. I2I.

I8 I Ketelsen, Literatur und Drittes Reich, pp. 199-200.

I82 Grimm, Volk ohne Raum, Foreword. 
comparison cost 2.85 RM. Of the 8.50 RM, Grimm was upset to discover that he was to receive royalties of only 60 pfennigs per copy. Grimm also expressed displeasure at the degree to which the Langen and Müller publishing houses had been merged, threatening to fall back on the unusual conditions of his contract with the ALV, which allowed him to withdraw all his books from the firm should it change hands. ${ }^{183} \mathrm{He}$ also disliked the way in which Pezold and Stapel applied moral pressure to persuade him that a cheap edition of Volk obne Raum was in the interest of the nationalist cause.

On 3ist July 1931, Pezold visited Grimm in Lippoldsberg, where the latter continued to prove intransigent. Above all, he demanded the continued right to remove his works from the LMV in the event of changed ownership. He also reserved the right to publish any future works with other firms. As a concession, he was prepared to guarantee not to make use of these rights as long as Pezold was in charge. This would prove important in the future. Practically speaking, he won himself a privileged position. For the Volksausgabe, moreover, he received an assured royalty of 240,000 RM over a period of eight years, almost twice as much as Thomas Mann received for Buddenbrooks. In the end, he was granted royalties of I RM for each copy sold at $8.50 \mathrm{RM} .{ }^{184}$

Pezold believed that a cheap edition of Volk obne Raum would satisfy an existing demand, even at the relatively high price he proposed. Moreover, the political goals of the project were important; success in winning the LMV a place as a leading publisher of nationalist literature would at least partially offset any losses incurred in the process. ${ }^{185}$ In order to achieve his dual goal, Pezold embarked on an aggressive advertising campaign. His efforts did not go unrewarded and four weeks after its appearance, on I6th November 1931, he was able to boast in a notice in the Börsenblatt that the first 50,000 copies had been sold. ${ }^{186}$ By December, only two months after

I83 Meyer, Die Verlagsfusion, p. II2.

I84 Ibid., pp. II5-II7.

I85 Ibid. p. II7.

I86 Ibid. pp. I20-I22. 
its publication, the new edition had more than doubled the total sales of Volk ohne Raum since its initial publication in 1926. Pezold made it one of the most prominent völkisch-nationalist novels of the Weimar period and gave the LMV a clear identity, placing it securely on the map of right-wing, conservative publishing.

Kolbenheyer's role in the DHV's purchase and merger of the two publishing houses and Grimm's unusual contractual agreement with the LMV are evidence of a unique relationship between the firm and its authors, based on a shared völkisch-nationalist belief in literature as both the bearer and the transmitter of the German Geist. Following the publication of the Volksausgabe of Volk obne Raum, Grimm's attitude towards the firm was based simply on its success in fulfilling the völkisch-nationalist task. Grimm thus attempted to bring other völkisch-nationalists and conservatives to the firm. Whilst in Berlin in the early 1930s, he made the acquaintance of Ernst Jünger and recommended that the LMV should publish Der Arbeiter. ${ }^{187}$ At the time, Jünger was already in negotiation with the Wilhelm-KornVerlag in Breslau. Grimm succeeded in winning him away from that firm, although Jünger finally published his book with the LMV's sister firm, the Hanseatische Verlagsanstalt. Grimm's attempt to engage August Winnig for the LMV ended in the same result. ${ }^{188}$

Personal relations between the publishing house and its authors were also enhanced by the LMV's location in Munich, a city that attracted many conservative and völkisch-nationalist writers in the 1920 s and 1930s. Paul Alverdes, Georg Britting, Richard Billinger and Josef Magnus Wehner all lived in the city itself. Hanns Johst and Benno von Mechow lived in the surrounding area. Moreover, while Paul Ernst lived in Carinthia in Austria, Wilhelm Schäfer, Emil Strauß and Kolbenheyer all lived in southern Germany, the latter moving from Tübingen to Munich-Sölln in 1932. Kolbenheyer later claimed that he was motivated to move by the desire to contribute to remedying the 'dreary cultural-political situation of German literature around

I87 Ernst Jünger, Der Arbeiter: Herrschaft und Gestalt (Hamburg: Hanseatische Verlagsanstalt, 1932).

I88 Lokatis, Die Hanseatische Verlagsanstalt, pp. 27, 44. Meyer, Die Verlagsfusion, p. I 48. 
I93I and 1932. ${ }^{189}$ In his history of the LMV Meyer suggests, however, that Kolbenheyer wanted to put himself in a position to exert a greater influence over the publishing house. In 1933, Ernst Wiechert also moved to Ambach, just outside Munich, once the books he published with the LMV had secured him a stable income that allowed him to live as a full-time writer. ${ }^{190}$ The publishing house thus became a central point for völkisch-nationalist and conservative literature not only ideologically, but also geographically, and played a significant role in strengthening and maintaining völkisch literary networks in the i930s.

\section{Völkisch-Nationalist Responses to the First World War}

Before the outbreak of the First World War völkisch literature was securely rooted in mainstream literary life in Germany. The völkisch-nationalist ideology, articulated in völkisch literature, provided Germans with an historically rooted identity in the face of modern insecurity. In the years before 1914, the reality of the Kaiserreich nonetheless seemed increasingly far from the völkisch ideal of a unified Germany. Between I87I and the outbreak of the First World War in 1914, völkisch-nationalists increasingly emphasised the importance of war as they grew impatient with the cultural and political stagnation they identified in contemporary society. Suffering was considered a prerequisite of creativity and the virtues of the struggle a way of cleansing the German Volk of its decadence. War offered men the chance to become heroes, freeing them from the routine and passive complacency of everyday life and making the Volk vital once more. Military service educated men to this end. ${ }^{191}$ War was viewed as a natural part of human

189 Kolbenheyer, Sebastian Karst, vol. III, pp. 107-109.

190 Ibid. pp. 145-146.

191 'Völkische Hochziele - Das deutsche Heer', Deutsches Handelsblatt (Hamburg, i6. Jahrgang, Nr. 15: 1.08.1909), FfZ: 522I. 
existence, necessary for weeding out the weak and degenerate elements in the Volk, ensuring its biological and spiritual health. Völkisch-nationalists therefore greeted the outbreak of the First World War with enthusiasm, in the belief that the war would create the necessary conditions for the renewal of German society. The Kaiser's words in August 1914, 'I no longer know parties, I know only Germans ${ }^{{ }^{192}}$ were received as a declaration of the dawning Volksgemeinschaft, or national community of the German people. ${ }^{193}$ For the first time in the history of Germany as a unified state its population was apparently united by a common purpose, which inspired a feeling of spiritual unity that, according to völkisch commentators, had been missing since $187 \mathrm{I}$. It also gave further impetus to the anti-western position of many völkisch-nationalists, who conceived their ideal of the German Volksgemeinschaft in opposition to the materialist capitalism of the Anglo-Saxon world.

Arthur Moeller van den Bruck has been recognised as a leading figure of the 'conservative revolution' in the Weimar Republic, alongside the brothers Ernst and Friedrich Georg Jünger and Oswald Spengler. ${ }^{194}$ Yet Fritz Stern identifies him instead as 'the last and in some ways the most admirable of the Germanic critics', emerging in the decade before the outbreak of the First World War. Stern asserts that: '... in him [Moeller van den Bruck] we can understand that the conservative revolution was not a spontaneous or reactionary opposition to Versailles or to the Weimar Republic, but was the reformulation under more favorable conditions of a nineteenth century ideology. ${ }^{195}$ This is evident in Moeller van den Bruck's pre-war work, which provided the ideological foundations for his most

192 Quoted in Hermand, Der alte Traum vom neuen Reich, p. 94.

193 On the various responses to the 'August Days' in Germany, see Peter Fritzsche, Germans into Nazis (Cambridge, MA: Harvard University Press, 1998), pp. 3-9; 13-31; Heinrich August Winkler, Der lange Weg nach Westen (Munich: Beck, 2002), vol. I, pp. 333-336; Hartmut Pogge von Strandmann, 'Germany and the Coming of War' in R.J.W. Evans and Hartmut Pogge von Strandmann (eds), The Coming of the First World War (Oxford: Clarendon Press, 1988), pp. IOI-102.

194 See Breuer, Anatomie der Konservativen Revolution, p. 3.

195 Stern, The Politics of Cultural Despair, p. 23I. 
famous work, Das Dritte Reich (1922). In Die moderne Literatur, published in 1902, Moeller already argued for the social and spiritual cleansing that war would provide: 'Fighting is magnificent and more worthy of man than self-indulgence in smug comfort. Battle gives us, especially when it is of spirits and passions, our greatest kings and best heroes. ... Eternal peace would be unsupportable - it would be a boredom, a yawning that would give us merely the philistine. ${ }^{3196}$ In short, he argued, the virtues of the struggle could ennoble the Volk.

The extent to which völkisch ideas informed Moeller's work is revealed most clearly, however, in Die Deutschen, an eight-volume history of the Germans published between 1904 and 1910, in which he sought to glorify his Volk through biographical essays on its great figures. ${ }^{197}$ In the years leading up to the First World War, Moeller also published an examination of contemporary culture and its leading figures, ${ }^{198}$ and managed to sell the idea of a six-volume series to the Munich publisher Reinhard Piper, three volumes on the old Völker - in Moeller's view Britain, France and Italy - and three on the new - Germany, America and Russia. The only work of the series ever published was that on Italy. ${ }^{199} \mathrm{His}$ plans for the works nonetheless demonstrate 'his celebrated distinction among old, young, and embryonic peoples. ${ }^{200}$ Young peoples, he believed, could claim privileges in the course of realising a great future. Of those listed above, Germany was the only truly young Volk, being bold, energetic and capable of expansion. Germany therefore had a right to imperial power. ${ }^{201}$

196 Arthur Moeller van Bruck, Die moderne Literatur (Berlin and Leipzig: Schuster \& Loeffler, 1902), p. 608. Quoted in Stern, The Politics of Cultural Despair, p. 237.

197 Arthur Moeller van den Bruck, Die Deutschen (Minden: Bruns, 1904-1910).

I98 Arthur Moeller van den Bruck, Die Zeitgenossen: Die Geister - die Menschen (Minden: Bruns, 1906).

199 Arthur Moeller van den Bruck, Die italienische Schönheit (Munich: Piper, 1913).

200 Stern, The Politics of Cultural Despair, p. 251.

20 I Arthur Moeller van den Bruck, Das Recht der jüngen Völker (edition consulted: Hamburg: Hanseatische Verlagsanstalt, 1932); see Stern, The Politics of Cultural Despair, p. 25I. On Moeller van den Bruck's relationship with völkisch thought, see also André Schlüter, Moeller van den Bruck: Leben und Werk (Cologne: Böhlau, 2010), pp. vi, 98, II3. 
Moeller van den Bruck's political views were based not on pragmatic assessments of actual situations, but on an aesthetic idealism that opposed the banality of the Kaiserreich and spoke directly to the concerns of völkischnationalists. Like them, Moeller van den Bruck was revolutionary before the First World War. He already called for the complete reorganisation of German society based on a vision of a community of the people and led by a leader who would emerge from the masses. Thus the Führerprinzip would be applied. Germany should also expand territorially, providing the German people with the space to realise their great fate. ${ }^{202}$ As it became apparent that the war was not going to yield an easy victory the metaphors of heroism and sacrifice that had characterised propaganda both in the trenches and on the home front gave way to an emphasis on the stoic endurance of the soldiers serving their Fatherland. ${ }^{203}$ This was also reflected in völkisch-nationalists' responses to the conflict. In the end, however, their common experience was manifested not in the sunshine of victory but in the shadow of defeat. The lost war focused völkisch-nationalist attention on outward circumstances - the Versailles Treaty, the republican state - to a degree that had hitherto been impossible. In the post-war years idealism gave way to pragmatic, even extreme, action.

Throughout the Weimar period, the First World War was the single most important influence on the development of völkisch literature. Its significance was both political and symbolic, giving writers the chance to tackle themes of völkisch-nationalist thought in a context that touched the lives of the entire population. In their works, images of German heroes survived in accounts of individual battles and campaigns. Countless books attempted to restore Germany's lost pride by analysing significant battles to show German courage and military success. ${ }^{204}$ The memoirs of veterans

202 Stern, The Politics of Cultural Despair, pp. 244; 264-265.

203 Roger Chickering, Imperial Germany and the Great War, I9I4-19I8 (Cambridge: Cambridge University Press, 1998), p. 97; Michael Burleigh, The Third Reich: A New History (London: Pan, 2000), p. 30 ; Uwe Lohalm, Völkischer Radikalismus, pp. 72-73. Ketelsen, Völkisch-nationalistische und nationalsozialistische Literatur, pp. 54-55; Sontheimer, Antidemokratisches Denken, pp. I21-I22.

204 For example: Juan Winkelhagen, Das Rätsel vom Skagerrak (Leipzig: Weicher, 1925), reviewed in the Völkische Bücherschau, No. 2, May 1925. Other völkisch-nationalist 
were also popular in the post-war years, and the camaraderie of the trenches was glorified in novels and accounts of the front. The appearance in 1929 of Erich Maria Remarque's anti-war novel Im Westen nichts Neues ${ }^{205}$ unleashed a new wave of nationalist publications that countered his negative view of the War with glorified accounts of their authors' own experiences based on pre-I9I4 nationalist ideas of war as the ultimate test of manhood and heroism. The writers' direct involvement in the events they described lent credibility to their emphasis on the importance of deeds over words and gave their books added authority. ${ }^{206}$

Continuing the wartime struggle, the Freikorps campaigns in German border regions and the vigilante operations and political murders of extreme right-wing groups, like the Organisation Consul, provided further subject matter for writers determined to chronicle the ongoing völkisch struggle. ${ }^{207}$ These hastily formed bands of volunteers were initially formed to help protect Germany's eastern borders, to defend German interests in the Baltic region and resist left-wing subversion within Germany. The Freikorps consisted largely of First World War veterans. The army had provided them with their raison d'être and it seemed natural to seek refuge from defeat in

works on the war reviewed in the same publication included: Unvergessenes Heldentum: Das Kolonisationswerk der deutschen Schutztruppe und Marine (Berlin: Kolonialwarte, 1925) and Admiral Michelsen, Der U-Bootkrieg I9I4/I9I8 (Leipzig: Koehler, 1925). See Völkische Bücherschau, Nr.2, May 1925, FfZ: 36213 , Verlagswesen.

205 Erich Maria Remarque, Im Westen nichts Neues (Berlin: Propyläen-Verlag, 1929).

206 For example, Franz Schauwecker, Aufbruch der Nation (Berlin: Deutsche Buchgemeinschaft, 1929); Paul C. Ettighoffer: Gespenster am toten Mann (Cologne: Gilde-Verlag, 1931); Feldgrau schafft Dividende (Cologne: Gilde-Verlag, 1932); Von der Teufelsinsel zum Leben (Cologne: Gilde-Verlag, 1932). For further discussion of First World War literature see: David Midgley, Writing Weimar: Critical Realism in German Literature, I9I8-1933 (Oxford: Oxford University Press, 2000), chapter 6; Sontheimer, Anti-Demokratisches Denken, pp. 96; II8-II9; Ketelsen, Völkischnationale und nationalsozialistische Literatur, pp. 69-71; Hans-Harald Müller, Der Krieg und die Schrisftsteller: Der Kriegsroman der Weimarer Republik (Stuttgart: Metzler, 1986), pp. 298-299.

207 For example, Hans Zöberlein, Der Glaube an Deutschland: Ein Kriegserleben von Verdun bis zum Umsturz (Munich: Eher, 1931), p. 890. 
the comradeship that had developed in the trenches. Ernst von Salomon summed up their position at the beginning of Die Geächteten:

These, these weren't workers, farmers, students, no these weren't artisans, clerks, businessmen, officials, these were soldiers. Not men dressed up, following orders, not deployed; these were men who had obeyed the call, the secret call of blood, of spirit, volunteers, men who, one way or another, experienced a hard common cause and the things behind the things - and who found a homeland in the war. Homeland, Fatherland, Volk, Nation! ${ }^{208}$

In 1918, von Salomon asserted, they no longer knew what Germany meant. ${ }^{209}$ They were particularly susceptible to völkisch propaganda, and anti-Semitism, which provided them with an explanation for their problems and an enemy against which they could continue the struggle they had waged at the front. ${ }^{210}$ Völkisch ideology thus informed the further development of their nationalism in the Weimar Republic. ${ }^{211}$

Following the passage of a new army law in March 1921 the Freikorps were officially disbanded. Many groups, however, went underground. ${ }^{212}$ Anti-republican and völkisch writers on the right elevated the perpetrators of political crimes carried out in the name of Germany to heroes of the German Volk. Their participation in the war had won them the right to determine Germany's future. ${ }^{213}$ Right-wing writers also propagated the

208 Ernst von Salomon, Die Geächteten (Berlin: Rowohlt, I930), p. 34.

209 Salomon, Die Geächteten, pp. 8I-82. See also Ernst von Salomon (pseudonym: Ernst Friedrich), 'Stahlhelm und Rotfront' in Deutsche Front, 3 rd June edition, 1928, DLA - A: Ernst von Salomon, Box I.

210 See, for example, Arnold Bronnen's biography of General Roßbach, leader of the Freikorps unit bearing his name: Roßbach (Berlin: Rowohlt, 1930), p. 70.

2 II Salomon, Die Geächteten, pp. II2-II4. See also Lohalm, Völkischer Radikalismus, p. 216.

2 I2 Howard Stern, 'The Organisation Consul', Journal of Modern History, vol. 35, No. I (March 1963), pp. 20-32. Here p. 23. See also: Goodrick-Clarke, The Occult Roots of Nazism, pp. 75-76; Emil Julius Gumbel, a mathematician, counted almost 400 murders and several thousand assaults as Feme crimes after 1918. Emil J. Gumbel, Vom Fememord zur Reichskanzlei (Heidelberg: Lambert Schneiderer, 1962).

213 Sontheimer, Antidemokratisches Denken, p. I2I. 
Dolchstoßlegende, which contested the outcome of the war by suggesting that Germany had not been defeated militarily, and campaigned for the return of Germany's lost territories and the reinstatement of her status as a great power, the latter in full recognition that this was likely to happen by force. Alongside the glorification of German heroism in the First World War, the consequences of Germany's defeat also provided inspiration for völkisch literature in the Weimar Republic. Opposition to the terms of the Versailles Treaty, the German revolution of 1918/19, and the French occupation of the industrial Ruhr region in 1923 were all subjects of discussion. ${ }^{214}$ In 1922 Wilhelm Schäfer, a 54 year-old writer and editor of Die Rheinlande, a significant journal of the Heimatkunstbewegung, located Germany at the centre of a ring of enemies: the country had been betrayed on all sides. Wilson, with his fourteen points, had declared that the war was with the Kaiser, not with Germany. Yet the Kaiser's abdication, itself a betrayal of his Volk, had done nothing to soften the peace settlement with

214 For example, the discussion concerning the Denkschrift über die Ausschreitungen der Besatzungstruppen im besetzten Gebiet (Berlin: Heymann, 1925) in the Völkische Bücherschau, No. 2, May 1925, FfZ: 36213 , Verlagswesen. Also Friedrich Grimm, 'Frankreich und wir', excerpt from his book Frankreich am Rhein (Hamburg: HAVA, 1931) in Hava-Bücherbrief. Politik-Geschichte-Kultur, No. 3, Hamburg, February 1932; Prof. Dr. Grimm, 'Der Kampf gegen die Separatisten', Hava-Bücherbrief. PolitikGeschichte-Kultur, No. 2, Hamburg, December 1931, pp. 2-3. This article, which is also an excerpt from the aforementioned book, deals with the German struggle against separatists in the Palatinate, who were, according to Grimm, supported by the French. Further völkisch-nationalist works on the subject included: Hans Blüher, Die Erhebung Israels gegen die christlichen Güter (Hamburg: Hanseatische Verlaganstalt, 1931). See also Hans Blüher, 'Der deutsch-französische Friede', HavaBücherbiref. Politik-Geschichte-Kultur, No. 3, Hamburg, February 1932, pp. 4-5; Fritz Klein, '1923 als Paradigma' from Auf die Barrikaden, Hava-Bücherbrief, No. 3 , February, 1932, pp. 5-6. With particular reference to Albert Leo Schlageter, famous as a resistance fighter against the French occupation of the Rhineland in 1923, see Hans Sadowsky, Lebenslänglich Zwangsarbeit (Berlin: Fridericus Verlag). 'Bücherumschau zur Femefrage', Korrespondenz: Nachrichtenblatt aus den deutschen Grenzgebieten im bedrobten Osten, 22 September 1930; Friedrich Glombowski, 'In Memorium Schlageter', Korrespondenz, I. Jahrgang, Oppeln, 22 October 1930, Folge 4. FfZ: 412-419, Nationale und Völkische Verbände; also: Winkler, Weimar I9I8-1933, p. 195. 
Germany; the fourteen points had achieved little; the League of Nations was trapped in its own bureaucracy; German troops had been betrayed by Communists and Jews; and the economy had collapsed. In short, Schäfer argued, 'all that was corrupt and sly, mean, double-tongued and self-serving had been consecrated; all that was true and straightforward, noble, just and altruistic, had been abandoned. ${ }^{215}$

Schäfer's Dreizehn Bücher der deutschen Seele, he recalled in 1937, was written out of Germany's hopelessness after the war, and called for a new start. ${ }^{216}$ In Schäfer's post-war works, he linked the social and the national by viewing Germany's defeat as the starting point for addressing social and cultural problems from a völkisch perspective. Schäfer demanded that Germany admit her war-guilt. He was not, however, referring, as the victorious Allies did, to her role in causing the war. Instead, he suggested that Germany, like all the belligerent nations, needed to acknowledge her guilt in prioritising the national economy and material gain over the nurture and promotion of the Volk. Seen from the German perspective in 1918, this guilt, shared equally between the nations in question, had caused the implosion of European civilisation. As a result, Schäfer, like Moeller van den Bruck in Das Dritte Reich, called for a new beginning that would redress the balance. The Weimar Republic, the product of Social Democracy and capitalist modernity, was the wrong answer. ${ }^{217}$

Schäfer's attitude towards the Jews was ambiguous. In 1923 , he outlined his views in a speech entitled Die deutsche Judenfrage. ${ }^{218}$ Here he praised the contribution made by German Jews to German culture. At the same time he highlighted a deep chasm between the German and the Jewish spirit. In this way, he was able to accept Jews as German citizens but not as members of the German Volk. Assimilation was not only impossible, but dangerous, leading to an adulteration of German culture. An even greater

215 Wilhelm Schäfer, Die dreizehn Bücher der deutschen Seele (Munich: Langen-Müller, I922), p. 403.

216 Wilhelm Schäfer, Mein Lebenswerk: Dankrede bei der Verleibung des Rheinischen Literaturpreises in Köln am I3. November 1937 (Munich: Langen-Müller, 1937), pp. 4-5.

217 Würmann, 'Vom Volksschullehrer zum “vaterländischen Erzieher”', p. I54.

2 I8 Wilhelm Schäfer, 'Die deutsche Judenfrage' in Der deutsche Gott (Munich: LMV, I923), pp. 2II-266. 
danger, however, were those Jews who espoused modernist culture, which sought to eradicate the differences between Völker altogether. Logically, therefore, he supported the efforts of the Zionists, who understood the differences between the Germans and the Jews. Schäfer's concern was the maintenance of the cultural and racial purity of the individual Völker. ${ }^{219}$

Sontheimer observes that the Kriegserlebnis that had such a stark impact on the political culture of the Weimar Republic was far more homogeneous than the experiences that formed German collective memory of the Second World War. ${ }^{20}$ The First World War demonstrated the nature of industrial warfare for the first time and its impersonal and amoral quality provided all those involved with a common experience. On the German right, at least, this single, widely shared experience proved to be a unifying force for the previously disparate adherents to völkisch-nationalism. It provided them with a new context in which to understand their ideals of camaraderie and community, just as the consequences of the lost war left them with a new context in which to apply their ideology. Nonetheless, the fundamental characteristics of this ideology remained those made familiar by völkisch-nationalists during the Kaiserreich: a racial worldview based on the Volk defined by blood; a socialpolitical ideology formed around the idea of the Volksgemeinschaft led by a Führer and consisting of all European Germans; a belief in Germany's rightful position in the world as a great power. These were also the terms adopted by Hitler and the newly formed Nazi Party in the rozos.

\section{Völkisch Writers and the NSDAP}

A number of commentators, and not only those on the extreme right with first-hand experience of Nazi literary life, have observed that the relationship between representatives of völkisch-nationalism and the Nazi Party was

219 Ibid.

220 Sontheimer, Anti-demokratisches Denken, p. II5. 
more complex than those seeking in völkisch activity the roots of National Socialism may have suggested. ${ }^{221}$ Once established as the Nazi Gauleiter in Berlin from 1926, Joseph Goebbels in particular went to considerable lengths to court prominent writers whose political position appeared to be in line with the Nazis' own. This was partly due to the lack of first-class literary representatives in the NSDAP's own ranks. It probably also reflects Goebbels' self-image as an intellectual, based on his academic background and attempts to write fiction. ${ }^{222}$

Goebbels was already in regular contact with Hans Grimm before 1933, ${ }^{223}$ although Grimm's consistent refusal to join the NSDAP, central to the defence of his position after 1945, was already evident in their early correspondence. It was clearly important to Goebbels to win the support of the author of Volk obne Raum, one of the most successful 'serious' works to emerge from nationalist circles in the I920s. Goebbels began to cultivate Grimm shortly after the publication of Volk ohne Raum and Goebbels' own arrival in Berlin. He arranged for Grimm to meet Hitler in 1928 and, in 1931, for him to participate in a meeting of the Harzburg Front. ${ }^{224}$ On I5th February of the same year, he described Grimm in his diary:

Midday at table with Hans Grimm. A reticent, gentle Lower Saxon, tall, somewhat lumbering, but thereby of a calming goodness and an assured cleverness. He views politics very clearly. For him we are the best chance for Germany and therefore he supports us. But wholly without pathos or ranting. Full of contempt for the Literatentum, strongly against Jünger, very good and loyal towards Hitler. I immediately conquer

22I Uwe Puschner, Walter Schmitz, Justus H. Ulbricht, 'Introduction' to Handbuch zurvölkischen Bewegung', pp. IX-X. Puschner et al., note in particular comments by the conservative scholar Armin Mohler, who worked as Ernst Jünger's private secretary after 1945. Mohler asserted that the völkisch movement should be viewed as a component of the 'conservative revolution' rather than related to National Socialism.

222 See, for example, Jan Andres, 'Die Konservative Revolution in der Weimarer Republik und Joseph Goebbels' Michael-Roman (1929)', Jahrbuch zur Kultur und Literatur der Weimarer Republik II (2007), pp. I4I-I65.

223 Fröhlich (ed.), Die Tagebücher von Joseph Goebbels, part I, volume 2 (Munich: Saur, 1987) I5.2.1931, p. 21; 31.3.1932, p. I49.

224 Barbian, Literaturpolitik, p. 403. 
his heart. He is moved when I speak of the duties that the German-conscious minds have towards us. That definitely touches his conscience. He then gives himself over completely to us. Civil courage! Bravo! We need lots like him. We part as friends, with the wish to meet again often. That is a prize! The author of 'Volk ohne Raum' stands under our flag. ${ }^{25}$

In his autobiographical work of 1954, Warum - Woher - Aber Wohin? Grimm's accounts of his meetings with Goebbels and his experiences at the Harzburg Front also point to a positive, almost friendly relationship between the two men in these years. Grimm regularly met Goebbels socially between 1930 and 1932 , a period in which he spent several winter months each year in Berlin, in order, as he later explained, to follow the political situation at first hand. ${ }^{226}$

Grimm's post-1945 accounts were written as part of his effort to reinterpret the history of the Nazi phenomenon after the War. In particular, he took pains to demonstrate that National Socialism had started out idealistically. ${ }^{227}$ This interpretation reflected his experience of Nazism in its early years. He suggested that during their first conversation, Goebbels had not appeared completely secure in his opinion of Hitler. Grimm implied that he gained the confidence of the future Propaganda Minister, who appeared to welcome an opportunity to discuss his private doubts. He also suggested that at this stage, in private, Goebbels was far from narrow-minded, contrasting with Grimm's later experience of the Propaganda Minister in 1938, when Goebbels reprimanded him for the annual literary meetings he held at his home in Lippoldsberg. ${ }^{228}$

Grimm's descriptions of his contacts with Hitler were more mixed. After 1945, he distanced himself from personal sympathy for Hitler, but emphasised that there were no other options for Germany in the late 1920 s and early 1930s. Grimm described his first meeting with the Nazi leader,

225 Fröhlich (ed.), Die Tagebücher von Joseph Goebbels, part I, volume 2, isth February, I93I, p. 2I.

226 Hans Grimm, Warum - Woher - Aber Wohin?, p. II5.

227 This is also clear in Grimm's correspondence with Agnes Miegel after 1945. See Chapter 5 .

228 Hans Grimm, Warum - Woher - Aber Wohin?, p. IIs. 
which occurred some time between 1928 and 1933 (the exact date is not clear in Grimm's text), in Warum - Woher - Aber Wobin? ${ }^{229}$ The encounter took place in Munich, where Grimm had been invited to meet the editorial staff of the Völkischer Beobachter. Grimm's description suggests that it was only a partial success. He argued that the Nazi leader had represented the European vanguard with his war against Bolshevism and for the future of the 'white race'. But Grimm's account of this first meeting also asserted the independent position Grimm maintained in relation to the NSDAP and emphasised the divergence of his political priorities, which were focused on Africa, from those of Hitler. Grimm made little impact when he embarked on a discussion of his main concern, the German residents of the former German South-West Africa, since I9I9 governed by South Africa under a League of Nations mandate. Hitler was adamant that Germany must avoid confrontation with the English, as well as the Boers, Dutch and other 'Germanic' peoples. The Nazi leader quickly let the subject of Africa fall, turning instead to the problem of Versailles and the 'Social Democratic' world created since the First World War. ${ }^{230}$

Grimm recalled his irritation at the way Hitler had brushed aside the African question. He also noted that Hitler became increasingly excited as he spoke, moving uncomfortably close to Grimm, whose chair ended up against the wall. On the other hand, Grimm declared himself impressed by Hitler's assertion that he was not the leader Germany was waiting for. This was typical of Grimm's post-1945 strategy of adopting a critical stand towards Hitler's person, whilst emphasising that he acted from motives for which Grimm had sympathy. His post-war reinterpretation of Hitler's politics was designed to serve Grimm's own political position in the postwar world, and will be discussed further in Chapter 5.

Grimm's description of his second encounter with Hitler during the meeting of the Harzburg Front in October 1931 provides broader observations of the politics of the extreme right-wing groups seeking to form a national front. Again, writing after 1945, he sought to distance himself

229 Ibid., pp. II2-II4

230 Ibid., pp. II3-II4. 
from the Nazis and at the same time apologise for them by presenting them as Germany's only realistic option in the early 1930s:

I saw Hitler for the second time at the Harzburg Conference on IIth October I93I. An attempt was to be made to create a National Front out of the German-Nationals and National-Socialists and the Stahlhelm. I listened to the excessive speeches as an independent German. Those men present with whom I felt a bond all belonged to the German-Nationals and the Stahlhelm; nonetheless I understood Hitler's bad temper. It was all too clear that this 'front' would not be able to solve any of the burning questions. The majority of those present looked back with reverence to the past, the upstart Hitler was of the opinion solutions would only be found by looking forward. ${ }^{231}$

This explains Grimm's support for National Socialism in the early I930s; he felt that the NSDAP would take action. An emphasis on deeds over words was well established on the völkisch right. Now, finally, they were embodied in the National Socialist movement, as Grimm demonstrated in a public appeal to the NSDAP published in the Berliner Börsenzeitung on 22nd September 1932. The text was co-signed by August Winnig, who had been the Social Democrat Oberpräsident of East Prussia between 1918 and 1920 before gaining a reputation as a publicist and moving increasingly towards the political right. It was published with the title Bitte an den Nationalsozialismus; in 1954, Grimm included it in Warum - Woher - Aber Wobin? along with an open letter from Goebbels published in response in the Nazi organ Der Angriff on 24th September 1932. ${ }^{232}$ Grimm emphasised in his post-war account that the appeal was, with the exception of one short extract by Winnig, written by him; Goebbels' response was also directed principally at Grimm.

In spite of his sympathy for the NSDAP's 'German' cause and his close acquaintance with Goebbels, Grimm strongly asserted his independence from party politics. His actions in the last years of the Weimar Republic were responses to the political culture of the republican system he rejected, not

23 I Ibid., p. I2I.

232 Ibid., pp. I23-I28. See also DLA, A: Grimm - Joseph Goebbels to Hans Grimm, 24.9.1932. 
least the role of the German press. The Bitte an den Nationalsozialismus placed the NSDAP in the context of the German right-wing as a whole. It began with an endorsement of the Hitlerbewegung. By referring to the NSDAP as a 'movement', Grimm deliberately emphasised its significance beyond narrow party politics. In line with völkisch thinking, Grimm rejected the party structures of Weimar republicanism, promoting instead the central importance of the völkisch-nationalist cause. At the same time, Grimm's discomfort with certain characteristics of the NSDAP, which Grimm viewed as a workers' party, are evident in this text. Appealing to the Nazis to transcend the workers' politics of Marxist socialism, he recognised and applauded the mass nature of the NSDAP as the most successful nonMarxist alternative for Germany's workers, harnessing them to German nationalism. As a result, for Grimm the NSDAP had proved itself to be the most effective available bulwark against Bolshevism. Nonetheless, while Grimm recognised the pragmatic benefits of Nazi mass politics, he remained elitist and an undertone of discomfort with the nature of the NSDAP is evident both in this text and in his general attitude to the Nazis at this time. ${ }^{233}$ The appeal went on to assert the necessary völkisch basis for workers' politics; the workers' movement needed to be harnessed to the German project as a whole. This aimed at reconnecting the German Volk with its Reich, as opposed to the kleindeutsch state established by Bismarck. The integration of Volk and Reich was the real prize; a resort to class struggle represented a dangerous distraction from resistance to the statist framework that Grimm identified with the Weimar Republic. For Grimm and Winnig, therefore, the NSDAP was the strongest and most authentic movement serving the German cause. ${ }^{234}$

Goebbels responded in an open letter addressed to Grimm in the Nazi organ Der Angriff. He publicly validated Grimm's understanding of his place as an independent, constructively critical commentator on National Socialism and presented the NSDAP in a light designed to appeal to those involved in the intellectual life of the nation. At the same time, Goebbels

233 Hans Grimm, Warum - Woher - Aber Wobin?, p. I24.

234 Ibid., p. I24. 
attacked the status quo in Germany in 1932, the political system and the liberal press, suggesting that the Nazis were victims of a campaign to discredit them. ${ }^{235} \mathrm{He}$ expressed appreciation that Grimm recognised the NSDAP as having rescued Germany 'from Communist dissolution and thereby from the complete extinction of the particular German intellectual and spiritual strengths, without which any form of resurrection was impossible' - Goebbels quoted directly from the text of Grimm and Winnig. ${ }^{236}$ The special role Goebbels claimed for the NSDAP in German politics had been earned through its actions over the previous twelve years. Thus, rather than appealing to the Nazis, he challenged Grimm and Winnig to direct their complaint at those who refused to clear the field in order to allow the Nazis to complete their historic task. Goebbels emphasised the NSDAP's character as a Volkspartei, which he understood in racial terms. ${ }^{237}$ Picking up on the comments by Grimm and Winnig on the subject of the German Reich, moreover, Goebbels moved the NSDAP away from older forms of nationalism and presented its credentials as a völkisch organisation: 'For us the Reich is not an empty phantom. We see in it not only a national instance, but also, and even more so today, a social instance. The one is unthinkable without the other, and only when we succeed in making the two into one will the miracle happen, that Volk and Reich will be conjoined.'238

In spite of Goebbels' response, in Warum - Woher - Aber Wohin? Grimm noted that it did little to allay the unexpected outcry the Bitte an den Nationalsozialismus raised in some quarters, including some Nazi offices. In particular, Grimm was criticised by the Nazi ideologue Alfred Rosenberg and his allies. Attacks on Grimm were published in the press, linked to his alleged attendance at a dinner in the Gardekavallerie-Kasino in Berlin, at which 300 wealthy, prominent men had apparently been present. They

235 Open letter from Goebbels in response to 'Bitte an den Nationalsozialismus' by Hans Grimm and August Winnig, published in Der Angriff, 24.09.1932; see also DLA, A: Grimm - Joseph Goebbels an Hans Grimm, 24.9.1932; Grimm, Warum - Woher Aber Wohin?, pp. 125-126.

236 Grimm, Warum - Woher - Aber Wohin? p. 126.

237 Ibid., pp. 126-127.

238 Ibid., pp. 127-I28. 
criticised Grimm for having challenged the NSDAP in its representation of the struggling working classes whilst at the same time dining lavishly with industrialists, politicians and other members of the establishment. ${ }^{239}$ In a letter to Goebbels, Grimm denied having attended the dinner, and warned of potential damage to the 'movement' presented by such publicity on the part of the NSDAP. He argued that this sort of reporting was little more than a continuation of the lies and inventions of 'Marxist' journalists deplored by Goebbels himself: 'The Jewish-Marxist journalists of my youth behaved in this way, as does the Jewish press against National Socialism, as did the enemy press against us during the World War: Lies and pious commentaries on their own lies. ${ }^{240}$

Rudolf Hess took pains to repair any damage done between the Party and Grimm. At the same time, his short letter in November 1932 also appears to be an attempt to paper over any differences within the Party, particularly between Rosenberg and other leaders. These were already evident and would come to the fore more clearly in the course of the decade. ${ }^{241}$ Hess also sent Grimm a pamphlet he had written in which he too had addressed the accusation that the NSDAP was developing too far into a movement engaged in class struggle. In Warum - Woher - Aber Wohin? Grimm wrote that he had been surprised to receive this letter; he did not know Hess personally at this stage. ${ }^{242}$ According to Hess himself, he had been present at Grimm's first meeting with Hitler. In his response to Heß in 1932 Grimm claimed that he was personally indifferent to the attacks, and maintained that he had been concerned that the campaign against him (but notably, not the appeal itself) had increased confusion in a time of hopeful transition. His letter to Heß on Isth November 1932 thanked $\mathrm{Heß}$ for writing and stated:

239 Grimm to Goebbels, 23.10.1932, DLA - A: Grimm, Hans Grimm to Joseph Goebbels, 23.10.1932; 21.3.1934.

240 Ibid.

24I Rudolf Hess to Hans Grimm, 3.II.1932, DLA, A: Grimm - Rudolf Hess to Grimm, 3.11.32 .

242 Grimm, Warum - Woher - Aber Wohin? p. I28. 
I am naturally aware that the Party and movement have different requirements. I am convinced that the success of Germany depends on the success of the 'NationalSocialist movement' and I act accordingly. I fear that the greatest enemies of the movement are currently to be found among the self-important, doctrinaire and lifelong insolvents in the Party. The Party should come as a welcome counterforce for those of us outside, who seek nothing for ourselves. But welcome or unwelcome, we are bound by our consciences to serve the German cause, and are pleased by every upstanding German we meet. ${ }^{243}$

With this Grimm outlined his own understanding of his position vis à vis the NSDAP and set the agenda for his actions in the Third Reich. ${ }^{244}$ The fact that his position outside but in support of the Party, retaining a right to deliver constructive criticism, was more or less accepted by the Nazis at this early stage allowed Grimm to assume that it would continue to be acceptable when they were in government. Certainly, reflecting on his later dealings with a far less friendly Goebbels, he referred back to these years to support his position throughout the 1930 s. $^{245}$ The various responses Grimm received to the 'Bitte an den Nationalsozialismus' also indicate that the NSDAP cultural leadership was already divided before the Party came to power. These divisions became more evident as internal rivalries, in particular between Rosenberg and Goebbels, became more intense in the years that followed.

The differences between Grimm and the Nazis in the late 1920 s rested more on a question of style than ideology. Grimm was not alone among völkisch-nationalists with his initial view of the NSDAP as a rabble-rousing mass movement that was incompatible with their elitist vision. In the Reichstag elections in 1930, for example, Grimm voted for the DNVP, whose 'manly uprightness and great political ability and internal party

243 Hans Grimm to Rudolf Hess, I5.II.1932, DLA, A: Grimm - Grimm to Rudolf Hess, I93I-I939.

244 From Grimm's correspondence with Goebbels in the years that followed, it would seem, however, that the matter was not laid to rest in 1932: See Grimm to Goebbels, 21.03.1934, DLA, A: Grimm - Grimm to Joseph Goebbels, 21.03.1934.

245 See discussion of Grimm's confrontation with Goebbels on pp. 26I-262. 
freedom' he admired. ${ }^{246}$ In the presidential election in the spring of 1932 , however, he reserved his vote for Hitler. ${ }^{247}$ For Grimm, the NSDAP at this time represented freedom from party politics. In line with the emphasis of older völkisch thought, and with Hitler's own rhetoric, he emphasised its character as a movement rather than a party and saw in it Germany's only hope for deliverance from the degradation of the Weimar years. While Grimm was never a Party member, Goebbels was pleased to note once again in his diary: 'The writer Hans Grimm openly endorses the Führer. ${ }^{248}$ In 1932, Grimm himself characterised his political activities as follows:

I have tried to provide the new national movement with quiet assistance from the day of its inception, unasked and unregistered. I did so seriously after the 9 th November 1923. I, the partyless, voted for the National Socialist Party, in spite of much that disturbed me, for the sake of the movement, which emerged around the Party and was supported by the Party as the bones support the body. ${ }^{249}$

In spite of Grimm's early support for the Nazi Party, and his importance in Germany as one of the leading nationalist writers of his time, it is very unlikely that either Hitler or Goebbels took the time to read the 1,300 pages of Volk ohne Raum or any of his other works. Unlike those of other writers, including the Norwegian Knut Hamsun and, closer to home, Wilhelm Schäfer, Goebbels does not mention Grimm's books in his diaries. ${ }^{250}$ The Nazis were less interested in Grimm's ideas than in his public standing. Grimm, on the other hand, saw a weightier role for himself as an independent commentator and cultural activist for the German cause, a misunderstanding that would cause problems in the future.

246 Quoted by Gerd Koch in '1936: Dichtertreffen bei Hans Grimm in Lippoldsberg', Zeitschrift für Germanistik (1994), No. 2, p. 343.

247 Ibid. p. 344.

248 Fröhlich (ed.), Die Tagebücher von Joseph Goebbels, part I, volume 2, 3ist February, 1932, p. I49.

249 Quoted by Koch, '1936: Dichtertreffen bei Hans Grimm', p. 344.

250 Goebbels discusses Wilhelm Schäfer's novel, Der Hauptmann von Köpenick (Munich: Müller, 1930) in Fröhlich (ed.), Die Tagebücher von Joseph Goebbels, part I, volume 2, 6th July, I931, p. 87. 


\section{E.G. Kolbenheyer's Speech to Students, 1932}

Adherents to the völkisch ideology greeted the Nazi Machtergreifung in January 1933 with enthusiasm. In the early I930s National Socialism appeared to present the only real chance to reorganise German society according to völkisch values and the establishment of the Third Reich marked a nationalist victory over the Weimar Republic. Hopes were further reinforced by Nazi rhetoric, which adopted many of the characteristics of the older völkisch-nationalist ideology. The Nazis proclaimed the establishment of a Volksgemeinschaft under the rule of the Führer and characterised by racial anti-Semitism. These terms had become familiar in German society at large as a result of the activities of völkisch-nationalists over the years.

In a speech delivered to student audiences at a number of German universities in 1932, Kolbenheyer discussed the role of literature in modern Germany, placing it in the broader context of his racial theories and demonstrating his concerns for Germany as the Weimar Republic limped through its final years. His speech provides a useful insight into his ideological position on the eve of the Nazi accession to power. Kolbenheyer responded to the question 'Ist deutsche Kultur am Ende?' which had been put to eight academics and writers by the Münchener Studentenschaft. Kolbenheyer's response provided a völkisch perspective on the cultural pessimism that he felt was intrinsic in the question. ${ }^{251}$ It was a question that, he suggested, reflected the spiritual state of modern society. Moreover, the problems faced by German culture had serious implications not only for Germany, but also Europe and America. In short, the health of German cultural life was intrinsic to the survival of the 'white race. ${ }^{252}$

For Kolbenheyer and his völkisch colleagues, German literature had a fundamental role to play in ensuring the future of the German Volk. It is

25I Erwin Guido Kolbenheyer, Unser Befreiungskampf und die deutsche Dichtkunst: Rede gehalten an deutschen Hochschulen im Frühjahr 1932 (Munich: Langen-Müller, I932), p. 3.

252 Ibid., p. 4 . 
notable that already in 1932 Kolbenheyer emphasised the interconnectedness of the 'white' peoples, a theme that he returned to after 1945. It is also notable that Kolbenheyer shared Grimm's view of international history over the previous two hundred years, which criticised Germany's neighbours for holding back German development over several centuries. ${ }^{253}$ The Treaty of Versailles was only the latest instance in this campaign against the German Volk. In addition, like Grimm, Kolbenheyer also saw a threat in the growing populations encroaching on western Europe from Asia. This threat was exacerbated by Communist expansionism after 1917.

Kolbenheyer's lecture was divided into two sections: the first discussed the biological function of the German Volk in the struggle to align the members of the 'white race' in a new structure that would create conditions for each of its constituent Völker to thrive, bringing their strengths to play for the benefit of the 'white race' as a whole. Having established this principle, the second part of his lecture addressed the specific role of literature in this process. ${ }^{254}$ Kolbenheyer claimed a scientific basis for his argument in line with the philosophy he outlined in his substantial work Die Baubütte. ${ }^{255}$ Thus, the process of alignment or adaptation (Anpassung) of the various 'white' Völker was one of biological adaptation rather than cultural assimilation or alignment.

In illustrating his ideas, Kolbenheyer raised two central themes in rightwing thought in the Weimar Republic: the idea of the 'decline' (Untergang) of the Volk and that of Lebensraum, both also themes central to Nazi rhetoric. For Kolbenheyer 'decline' was a reality that demanded a response. He argued that the völkisch tendency to look back to history to find a spiritual orientation in response to the contemporary world was inadequate; biological analysis was required. Kolbenheyer demanded forward-looking approaches drawn not from history but from a 'biological' understanding of the contemporary world and, in particular, the Anpassungskampf in which

253 Kolbenheyer, Sebastian Karst, vol. I, pp. 187-194, 233-236.

254 Kolbenheyer, Unser Befreiungskampf, pp. 4-5.

255 Erwin Guido Kolbenheyer, Die Baubütte - Grundzüge einer Metaphysik der Gegenwart (Munich: Langen, 1925). 
the German Volk was involved. This needed, moreover, to be viewed in an 'übervölkisch' context, which recognised a difference between the idea of race and that of Volk..$^{256}$

Kolbenheyer's approach was thus a little different to that of völkisch colleagues, including the Nazis, for whom the Germanic, Nordic or Aryan Volk was simply identified in racial terms. By contrast, Kolbenheyer viewed individual European Völker as constituents of the 'white race'. He emphasised the mutual dependence of the 'white race' and the German Volk. Kolbenheyer proposed that the Völker should develop closer relationships based on their shared biological identity. This would allow a combined response of the entire 'white race' to the problem of racial decline, without blurring the boundaries of the constituent Völker. ${ }^{257}$ Indeed, the possibility of an 'übervölkisch' reaction representing the 'white race' as a whole was created out of the dynamic tension between the different Völker, some 'old' and exhausted, others 'young' and still full of unused life. Here Kolbenheyer echoed Moeller van den Bruck's idea of young and old nations. The First World War was, in Kolbenheyer's analysis, only the latest instance in two thousand years of struggle as a result of this tension and intrinsic to the biological development of the 'white race'.

According to Kolbenheyer, the struggle between the Völker had been accompanied by a lack of space or Lebensraum. One of the indications that this struggle was in its final phase, he suggested, was the fact that this feeling was stronger than ever before in the face of economic hardship and rising unemployment. ${ }^{258}$ Previously, the problem had been understood simply as a question of population density. For Kolbenheyer, however, it was not about the number of people living off a piece of land, but whether that land was sufficient both in size and fertility to support those people and their biological development. ${ }^{259}$ The technologically advanced state of the European Völker, demonstrated during the First World War, meant that

256 Kolbenheyer, Unser Befreiungskampf, p. 5 .

257 Ibid., pp. 6-7.

258 Ibid., p. I2.

259 Ibid., pp. I2-I3. 
Europe was now too small to support them. The mistake of the Versailles peace settlement was its failure to recognise the biological needs of the German Volk and its importance for the future of Europe as a whole. For Kolbenheyer, the Versailles Treaty was the latest expression of what he described as the Mediterranean spirit and its drive throughout history to contain the Nordic-Germanic spirit. The latter sought not hegemony and centralisation, but the free development of the entire 'white race'. And it was in the quest to achieve this that Kolbenheyer saw the biological function of the German Volk, and therefore also the value of its literary creation. ${ }^{260}$

Kolbenheyer rejected aestheticism that judged art simply as art, but also distanced himself from a form of literature that simply served cultural or political ends. Polished form and style, though necessary, were not sufficient for the existence of a work of art; literature must serve as the mediation of the essence of the Volk. Similarly, literature that simply supported a Weltanschauung only served to validate an existing position and could not therefore be considered art. For Kolbenheyer,

Art should and must serve re-orderung and expansion. It is based therefore on the familiar and revered, in order to break through inurement and to bring about the new, which should possess a certain, calming form. Art that supports ethos is a creative agent that generates excitement creatively and through visual form. [...] It sets the observer free only after an internal struggle. To bring about constructive struggle requires mastery of form. Where a lack of form is exalted or replaced by ethos there is no literary art. ${ }^{261}$

For Kolbenheyer Dichtkunst represented the deepest, most inalienable expression of the individual Völker. ${ }^{262}$ The literary arts of a people provided not only insight into its specific character, but also the method of protecting and developing it. Conversely, however, literature also opened a Volk to potential instability and contamination. Thus Kolbenheyer contrasted his perspective on literature with the intellectualising tendencies

260 Ibid., p. 16.

26 I Ibid., p. I8.

262 Ibid., p. 20. 
he identified in recent generations. Kolbenheyer's criticism of the literary world of the Weimar Republic mirrored right-wing complaints about the liberal and left-wing press and publishing houses; it was not aimed at the German people as a whole, who were the victims not the perpetrators of this situation. ${ }^{263}$

\section{Conclusion}

The First World War did not substantially change völkisch ideology, but it had an enormous influence on völkisch actions in the Weimar Republic. It provided the völkisch movement with renewed momentum and a new focus. Throughout its history, the völkisch-nationalist landscape in Germany was always disparate and lacked clear categories. The same remained true for the Weimar Republic, during which völkisch-nationalists believed that they were continuing the fight that had been defined in I9I4 according to an older völkisch understanding of Germany. Völkisch literature remained central to the dissemination of the völkisch message in the Weimar Republic, with book clubs and right-wing organisations directing a steady readership towards material that endorsed their world-view.

In the Weimar Republic, völkisch-nationalists engaged more directly in political activism than they had in the Kaiserreich. In a period of economic and political instability they offered both an explanation and a solution for the problems of the German people. In striving towards a complete revision of the German social structure, the völkisch ideology was both political and revolutionary. It was based on intuitive rather than rational principles. While some völkisch activists absolutely rejected the democratic parliamentarianism of the Weimar Republic, others sought to work within it to achieve the völkisch revolution. Parties like the Deutschnationale Volkspartei (DNVP) and the NSDAP formed an increasingly powerful

263 Ibid., pp. $21-24$. 
right-wing bloc in the Reichstag in the late $1920{ }^{264}$ Völkisch-nationalists, and the message they spread through their literary output, were therefore inextricably bound up with the formation of a political consensus on the right during these years. The cooperation and competition between the Nazis and other völkisch groups, the influence of völkisch ideology on the development of the Nazi programme, and the similarities and differences between the movements will therefore be the subject of the next chapter.

In his lecture to the students in Munich, Kolbenheyer outlined a role for literature, and by extension German writers, that formed the basis of his expectations of the Nazi regime. For Kolbenheyer and his völkisch colleagues, as well as the Nazis responsible for the cultural sphere after 1933, literature had a role to play in the struggle for the future of the German Volk. Where tensions emerged, they were not about the nature of German literature itself, but about who should determine its course. For the völkischnationalists, literature must come from the Volk itself, the position of its creators thus confirmed by the works they had written rather than political patronage or favour; literature was not to serve a party programme or political propaganda, but solely the German people. While the Nazis were prepared to acknowledge this ideal in theory, as subsequent chapters will show, in practice the situation was more complex.

264 Thomas Mergel, 'Das Scheitern des deutschen Tory-Konservatismus: Die Umformung der DNVP zu einer rechtsradikalen Partei 1928-1932', Historische Zeitschrift, Band 276, Heft 2, April 2003, pp. 323-368. See also Eley, 'Conservatives and radical Nationalists', pp. 65-68. 


\section{Völkisch Writers and National Socialist Kulturpolitik}

Stefan Breuer has pointed out that National Socialism has defined the way völkisch ideas in Germany have been viewed by history; under other circumstances the multiple forms and contexts in which they were manifested might have led to different approaches. ${ }^{1}$ It is worth noting that a differentiated understanding of the völkisch phenomenon lay behind its reception by contemporaries prior to 1945 , both its adherents and opponents, and had a significant impact on the relationship between völkisch writers and the Nazis. It also underpinned völkisch interpretations of the Nazi regime following its downfall. Völkisch-nationalism was not a product of National Socialism, but did have a clear influence on Nazi ideology, rooting it in an older German tradition and providing an opportunity to appropriate widely recognised nationalist rhetoric. While some historians have pointed to a Nazi rejection of the 'völkisch movement', any stand made by the Nazis against völkisch-nationalism was at best contradictory and inconsistent, focused on a narrow understanding of völkisch ideology in terms of 'Teutschtümelei.'. ${ }^{2}$ Moreover, criticism of earlier völkisch organisations as ineffective was combined with the assertion that the Nazi movement itself was 'Vorkämpferin' and 'Repräsentantin' of the völkisch ideology because 'only the work of the NSDAP' made the term völkisch popular, endowing it with significant political weight. ${ }^{3}$

This chapter will consider the institutional landscape and some of the methods adopted by the Nazis to draw völkisch writers into the structures of the regime after 1933; those that follow will examine the responses

I Breuer, Die Völkischen in Deutschland, pp. 7-8.

2 Puschner et al., Handbuch zur 'völkischen Bewegung', pp. X-XI.

3 Quoted in Puschner, Die völkische Bewegung, p. 9. 
of the writers in question to the regime in various contexts. In this way, a differentiated view of völkisch thinkers on the German right will be presented without neglecting the importance of the Nazis and their influence on the ongoing ideological and institutional development of the völkisch literary landscape.

\section{Nazi Kulturpolitik before 1933}

The foundations for the Nazis' Kulturpolitik were laid in the Weimar Republic, not only within the NSDAP itself, but in the development of regulation of the cultural sphere, in particular the Republic's censorship measures. While the constitution of the Republic upheld freedom of speech, in the course of the 1920 s and early 1930 s concern regarding the production of works considered dangerous for young Germans led to the passage of the 'Law for the Protection of Youth against trashy and filthy Writing' (Gesetz zur Bewahrung der Jugend vor Schund- und Schmutzschriften), and the establishment of an office to compile indices of unsuitable works. ${ }^{4}$ Most effective in censoring literary works in the Weimar Republic, however, were laws that legitimated prosecution of left wing and liberal authors for blasphemy and legislated against high treason and for the protection of the Republic. It was not, however, only the left-wing writers who suffered from the courts' de facto censorship, but also writers who were in favour of the Republic: Thomas and Heinrich Mann, Carl von Ossietzky, Erich Maria Remarque and Carl Zuckmayer were all victims of the legal system, which continued to be dominated by conservative and nationalist officials. ${ }^{5}$ As a result, between 1918 and 1933 literary modernism faced significant institutional opposition from a censorship apparatus, on which the Nazis were able to build after 1933 .

4 Barbian, Literaturpolitik, pp. 49-5I.

5 Ibid. pp. 49-5I. 
At the Nuremburg Party Rally in 1927, it was decided that a NationalSocialist Society for Culture and Science should be formed to counter the negative image of Party members as instigators of street violence and political agitation. ${ }^{6}$ Intended as a means to disseminate the National Socialist worldview to those who were not reached by the mass events of the Party, it sought in particular to appeal to the Bildungsbürgertum. In a letter to Hans Grimm, Alfred Rosenberg called for support for the new organisation, explaining the thinking behind the initiative: 'As you will see from the enclosed, we are working to establish a National Socialist organisation, that plans to work on the foundations of our völkisch cultural work through lectures and similar events. It will be aimed less at the wider social classes, that can be won through mass assemblies, and more at the national intelligentsia, students etc. ${ }^{77}$ It was officially called into being at the beginning of 1928 as the Nationalsozialistische Gesellschaft für deutsche Kultur, its name changing to the Kampfbund für deutsche Kultur $(\mathrm{KfdK})$ a year later in order to play down its association with the NSDAP. Alongside several Party functionaries, the dramatist Hanns Johst and the industrialist Wilhelm Weiß were both on the steering committee. Other members included Erwin Guido Kolbenheyer and Adolf Bartels, as well as the publishers Julius F. Lehmann and Hugo Bruckmann, and Winifried Wagner and Eva Chamberlain, widow of Houston Stewart Chamberlain. ${ }^{8}$ Hans Grimm did not become a member.

The new organisation's debt to völkisch-nationalism was evident in its efforts to win support. A declaration enclosed with Rosenberg's letter to Grimm argued that the assertion of völkisch values was part of a struggle that could be reduced to two basic factors: first, the need to counter internationalism with the idea of a racially defined Volkstum. The international idea was allegedly manifested in politics that aimed to dismantle völkisch boundaries, promoting the melting-pot idea and demanding a united states

6 Rolf Düsterberg, Hanns Johst: 'Der Barde der SS': Karrieren eines deutschen Dichters (Paderborn: Schöningh, 2004), p. I24.

7 Alfred Rosenberg to Hans Grimm, ir.IO.I927, DLA, A: Grimm, Rosenberg to Grimm, II.IO.1927.

8 Düsterberg, Hanns Johst, pp. I24-I25. 
of the world. The last was presumably a reference to the League of Nations, associated on the German right with the victors' justice of the Paris peace negotiations in 1919. Economically, it was evident in the separation of economic activity from its regional or local roots, placing it under the control of a few international trusts and world banks. This tendency, the declaration argued, would lead to a purely materialist order.'

Parallel to these forces, the same pamphlet argued, were attempts to transcend national art and national culture in favour of the so-called art and culture of humanity (Menschheitskunst; Menschheitskultur). The idea of 'humanity' (Menschheit) represented limitless and unbounded individualism. Just as the goal of the international economic system was focused on profit and the economic sustainability of the trusts and big banks, so the idea of 'humanity' taught that the individual should be able to establish his or her life without any obligations to race, Volk, state, language and history. There was, however, a growing recognition that these tendencies would lead to chaos, inspiring the gathering of forces to counter this negative trend. At the head marched the National Socialist movement. It represented a rounded expression of a new life experience, demanding complete re-evaluation of Germany's economic, social and cultural life. ${ }^{10}$ Rosenberg's declaration continued by stating that nationalism had been damaged by the materialism of the nineteenth century. Similarly, international Marxism had corrupted pure socialism, uprooting it from its foundations in the Volk, preaching the abnegation of race and Volkstum and canonising class struggle. For the National Socialist movement, therefore, the only prerequisite for the revival of the Völk and for the rebirth of true culture was the conjunction of nationalism and socialism. The nationalist idea needed cleansing of its profit orientation; the socialist movement required purification to remove the poison of internationalism, class struggle and materialist individualism. It would become evident that the essence of nationalism and socialism in their pure forms were the same: the care II.IO.1927. Ibid. 
and cultivation of race and Volkstum. Cultural, political, economic and social concerns thereby intertwined, shaping the intellectual and physical existenc of each member of the Volk. ${ }^{11}$

The formal aim of the KfdK was 'to defend the value of the German being in the midst of the cultural degeneration of today, and to promote every outward expression of German cultural life. ${ }^{12}$ Rosenberg, already Chief Editor of the Völkischer Beobachter, was appointed director of the new organisation. Its tactics varied from articles in the Völkischer Beobachter's cultural section, and other Nazi publications, to the production and promotion of National Socialist works designed to counter the degenerate effects of republican and humanist writers. ${ }^{13}$ A 'Denkschrift' of 2Ist June 1932 proposed the foundation of a Kampfbund für deutsches Schriftum. This was to be led by Hanns Johst, who had himself suggested to Rosenberg at the beginning of that year that he be employed, at some considerable expense, by the Party as a cultural official responsible for monitoring the spheres of literature and theatre. A veteran of the First World War whose playwriting moved away from its Expressionist roots in the 1920 in response to Germany's defeat and the revolutionary events of 1918-1919, Johst also campaigned for Hitler in the Presidential elections of $1932 .{ }^{14}$ While his proposal to Rosenberg was not adopted, Johst was already close to the Party leadership and his loyal involvement with the NSDAP in the Weimar Republic made him one of its most prominent members in the literary sphere and placed him in a prime position for advancement in the Third Reich. In the end power came with his role in the Reichsschrifttumskammer, dominated by Goebbels, rather than any of the institutions through which Rosenberg sought to wield influence.

Rosenberg's völkisch message appealed to several prominent writers, including Kolbenheyer. And while Grimm, maintained his distance from the KfdK and never became a member of the Party, he did get involved

II Ibid.

I2 Quoted in Barbian, Literaturpolitik, p. 57.

I3 Ibid. pp. 56-6I.

I4 Düsterberg, Hanns Johst, pp. I28, I3I. 
informally with the NSDAP during the later years of the Weimar Republic. The inclusiveness that characterised Rosenberg's declaration in 1927 was also evident in Goebbels' contacts with Grimm. That it would give way to coercion after 1933 was not clear to the latter at this stage. In these years, therefore, a misconception found its roots, namely that the position of Grimm and his völkisch colleagues in relation to the NSDAP would remain unchanged after the Nazis came to power. They wrongly assumed that they would make an important and active contribution to determining the direction of German culture under the Nazis, who were not an end in themselves but would establish the necessary basis on which a truly völkisch social order could be achieved.

\section{The Politics of Literature in the Third Reich}

The instrumentalisation of völkisch writers was one of the goals of Nazi Literaturpolitik. In order for something to be instrumentalised, however, it must first exist in its own right. Völkisch literature was not a direct product of National Socialism and the creation of an institutional structure to encourage and coerce writers into cooperation did not necessarily guarantee their support. Like Hans Grimm, many felt that their leading position in the literary sphere, confirmed after 1933 by the interest shown by the new rulers in their work, or at least the prestige their names brought with them, endowed them with both the right and the responsibility to engage and comment independently on the state of Germany. Their support for the Nazi regime was, therefore, often expressed through a commitment to contributing to the völkisch revolution it promised by pointing out where development was still needed. As a result, doubts and internal resistance were evident even among writers who generally enjoyed a comfortable existence under the Nazi government. As we shall see below, Hans Grimm provides a useful example.

By January 1933 several cultural and literary institutions, as well as personnel, were already well established within the Nazi Party. Nevertheless, 
in order to execute their ideological aims, the Nazis had to expand the institutional structure which would govern German culture in the new Reich. This did not occur as a single action, but was the outcome of individual initiatives. The result was a collection of chaotic and often conflicting institutions and organisations whose spheres of activity and interests overlapped. For the Nazis literature was a tool for the dissemination of their Weltanschauung. In a speech to the Kulturtagung of the Party conference, delivered on Ist September 1933, Hitler laid down the principles on which Nazi cultural policies were to be based. He declared that National Socialism was the German Weltanschauung. ${ }^{15}$ He maintained that every Volk had its own Weltanschauung, passed on from generation to generation through the blood. That of the Germans had to be defended against outside threats and promoted by artists to ensure the German spirit would thrive in future ages. ${ }^{16} \mathrm{He}$ concluded by inviting German artists 'to join in taking on the proud defence of the German Volk through German art. ${ }^{17}$ Hitler's racial approach to art removed the need for originality. Instead of seeking to be progressive, he suggested that the primary purpose of art was to be an expression of the Volk, the essence of which was immutable and therefore not subject to the whims of fashion. For Hitler the will of the Volk, as well as its Weltanschauung, was represented by the Nazi Party. This meant that art, including literature, in the Third Reich was to reflect the standpoint of the Party. As a result, not only views that did not conform to the Party line, but also groups and networks that were not under Party control had to be stamped out in the literary sphere.

The relationships of individual writers with the regime were influenced to a large degree by the network of literary institutions in which a number of völkisch writers gained access to leading positions for the first time. Career advancement was not the only motivating factor for supporting the new government; it was natural for many völkisch thinkers to view the

Adolf Hitler, 'Die deutsche Kunst als stolzeste Verteidigung des deutschen Volkes' in Erhard Klöss (ed.), Reden des Führers. Politik und Propaganda Adolf Hitlers, I922-1945 (Munich: dtv, 1967), p. I09.

16 Ibid. p. 116. Ibid. p. 120. 
Nazi order positively. Moreover, it did not threaten all the institutions to which they belonged, introducing instead grades of Gleichschaltung: While political or 'racially' foreign organisations and individuals were removed; politically neutral independent organisations were sidelined. The Literature Section of the Prussian Academy of Arts provides an example of the latter and will be examined in Chapter 3 . In the practical regulation of the literary sphere, government machinery really functioned through new institutions created by the Nazis. Those appointed to head the most important were, on the whole, dedicated to the National Socialist movement; those who proved less reliable or effective, for example Hans-Friedrich Blunck in the Reichsschrifttumskammer (RSK), were removed, or encouraged to resign fairly early in the regime. ${ }^{18}$

The following sections will explore these frameworks, which were also those within which völkisch-nationalists were obliged to operate in the Third Reich. This will provide a basis for more detailed examination of specific cases in the following chapters, as well as an investigation of their post-war attitudes.

\section{Kulturpolitik}

Nazi Kulturpolitik has been the subject of a number of scholarly studies. As Ketelsen notes, these have frequently tended towards an instrumentalist interpretation, stating that the arts were simply utilised by the Nazis to spread the National Socialist Weltanschauung. ${ }^{19}$ This suggests the existence of a homogeneous National Socialist ideology providing a yardstick against which literature and the arts could be measured and forced to conform. The biggest advocates of this theory were the Nazi propaganda tives that actively supported the Nazi regime. 
and cultural officials themselves, who argued that the element of force required in order to reach a homogeneous system was justified by the unity of the ideological programme that the Nazis were working to implement. An instrumentalist interpretation is, however, too simple to describe the cultural scenery of the Third Reich. The Nazis did indeed deploy the cultural apparatus for political ends, seeking to achieve 'a revolution in attitudes and values, a transformation of subjective consciousness more than of objective realities. ${ }^{20}$ Nonetheless, the Kulturpolitik of the Third Reich was characterised by divisions and a lack of ideological agreement extending from the upper ranks of the Nazi Party to party functionaries at the humblest levels. Alfred Rosenberg's long-running conflict with Goebbels is, for example, well documented. ${ }^{21}$ It is therefore vital to differentiate clearly between the way the Nazis portrayed themselves and their Kulturpolitik, and the reality of the system. The development of literary institutions in the Third Reich was complicated. Temporary constellations and alliances in the government, as well as the whims of Hitler and his closest associates, and finally the political and social situation in Germany, contributed as much as a logical plan for the establishment of a functioning bureaucracy. ${ }^{22}$

The literary sphere of Nazi politics was governed by three institutional frameworks: the Reichsministerium für Volksaufklärung und Propaganda, the Reichskulturkammer, both dominated by Joseph Goebbels, and the Nazi Party's internal ideological apparatus, dominated by Alfred Rosenberg. Subordinated to each was a large network of individual institutions intended to control every aspect of literary endeavour and the production of the written word. The sheer number of organisations operating to control literary production, combined with a lack of clear guidance, gave the literary sphere an arbitrary nature and limited their efficiency. In the specific case of literature, however, the situation was further complicated by the lack of detailed interest and clear guidance from Hitler and the

Ian Kershaw, Popular Opinion and Political Dissent in the Third Reich: Bavaria, 1933-1945 (Oxford: Oxford University Press, 1982), p. I.

2I Reinhard Bollmus, Das Amt Rosenberg und seine Gegner. Zum Machtkampf im nationalsozialistischen Herrschaftssystem (Stuttgart. Deutsche Verlagsanstalt, 1970). Ibid. pp. 294-298. 
Party leaders. ${ }^{23}$ Even Goebbels, whose professed interest in literary matters was apparently confirmed by his Ph.D. in literary history as well as the publication of several books, paid more attention to radio and film. ${ }^{24}$ As a result, the practical application of Nazi cultural policies in the literary sphere was left to a collection of Nazi bureaucrats aided by sympathetic writers, allowing some writers to manipulate the anomalies and vagaries of an increasingly bureaucratic system, while others fell victim to the confused government of the literary sphere.

Overall the RSK dominated the institutions of Literaturpolitik. This was largely thanks to the fact that membership was obligatory for all those involved in literary production in the Third Reich, making it the largest

23 Spotts' point that Hitler's interest in literature was limited is corroborated by others who have investigated Hitler's reading habits. See Frederic Spotts, Hitler and the Power of Aesthetics (London: Hutchison, 2002), p. I6; also: Robert G.L. Waite, The Psychopathic God: AdolfHitler (New York: Basic Books, 1977), p. 6o. Hitler cultivated the impression that he was a wide reader, acquainted with the German classics as well as contemporary works in Mein Kampf (Munich 1926; Edition used: 1936), pp. 35-39. This is supported by the account of his childhood friend, August Kubizek, Hitler, mein Jugendfreund (Graz \& Stuttgart: Stockerer, 1995), pp. I88-189. Nonetheless, Kubizek's memoirs are notoriously unreliable, as is Hitler's own account of his early life. Brigitte Hamann notes that it is more likely that Hitler came across quotations from the works of German masters like Goethe and Schiller in the German nationalist press in Austria. See Brigitte Hamann, Hitlers Vienna: A Dictator's Apprenticeship (Oxford: Oxford University Press, 1999), pp. 74-76. With the exception of Karl May's novels and an illustrated history of the Franco-Prussian War in his childhood, and later also the Flottenalmanach and numerous anti-Semitic pamphlets, there is little evidence of Hitler's wider reading. See Ian Kershaw, Hitler, I898-1936: Hubris (London: Penguin, 1998), pp. 15-17. See also: Adolf Hitler, Mein Kampf, vol. I. (Munich: Eher, 1925), p. 173; Hitler's Table Talk, $1941-1944$, with an introductory essay on 'The Mind of Adolf Hitler' by H.R. Trevor-Roper (Oxford: Oxford University Press, 1953), p. 316.

24 As well as his novel, Michael: Ein deutsches Schicksal in Tagebuchblättern (Munich: Eher, 1929), Goebbels published several political works, namely: Signale der neuen Zeit. 25 ausgewählte Reden (Munich: Eher, 1937); Kampf um Berlin (Munich, 1939). See also Jan Andres, 'Die "Konservative Revolution” in der Weimarer Republik und Joseph Goebbels' “Michael” - Roman. Überlegungen zu einer möglichen Verbindung, in Jahrbuch zur Kultur und Literatur der Weimarer Republik (2007), pp. I4I-I65. 
organisation in the literary sphere. Nonetheless, its power was not so absolute that it removed all confusion. Furthermore, a single ideological vision of National Socialism and its proper relationship with literature was lacking. While the Nazis' declared goal was the deployment of the pen as one of the weapons of the Volksgemeinschaft, they were never successful in establishing a National Socialist literary genre. ${ }^{25}$ Instead they were forced to turn to existing nationalist literature to provide their Weltanschauung with a cultural underpinning. Völkisch-nationalism offered the Nazis a ready-made literary canon to support the regime, and several of their leading literary figures, including Hans Friedrich Blunck, emerged from this tradition.

Nonetheless, not all völkisch writers were prepared to subordinate their own ideals to those of the Nazis. The disparate nature of Literaturpolitik under the Nazis meant that the expectations of völkisch writers of the regime were badly managed, making it difficult for Grimm and his colleagues to identify their place in the new literary landscape. In the end, this lack of definition may have served the Literaturpolitik in the Third Reich, which aimed to gain control over groups that might prove subversive or simply outside Nazi control. By creating ambiguities and uncertainty, a climate of anxiety was established in which writers were never quite sure where they stood, thus forcing many to adopt a cautious approach. For those who refused to be sufficiently subservient, threats or actual punishment were available to force cooperation, as Goebbels attempted with Grimm in $1938 .{ }^{26}$ On an institutional level, the so-called Gleichschaltung of existing literary groups was one way in which Goebbels and Rosenberg sought to exclude unsympathetic authors, and break down well-established networks of writers of all political persuasions and replace them with new networks controlled from above. The literary institutions in the Third Reich did not only attempt to control literary output, but also made enormous inroads into the everyday lives and contacts of right wing, nationalist and völkisch writers.

25 Uwe-K. Ketelsen, 'NS-Literatur und Modernität' in Wulf Koepke and Michael Winkler (eds), Deutschsprachige Exilliteratur, pp. 37-55.

See discussion of Grimm's confrontation with Goebbels in 1938 on pp. 26I-262. 
Three broad methods of control were employed: controlled entry into the literary professions; censorship; and threats and incentives. The impact of these methods, applied through the extensive institutional structure governing the politics of literature in Nazi Germany combined with Goebbels' propaganda, was profound in German literary life. From the perspective of the Nazi government, literature was subsumed under the propaganda apparatus governed by the Reichsministerium für Volksaufklärung und Propaganda (RMVP). The Ministry was brought into being by a presidential decree on I2th March 1933 to be responsible for 'the intellectual direction of the nation'. Its task was the dissemination of 'enlightenment and propaganda within the population concerning the policies of the Reich Government and the national reconstruction of the German Fatherland. ${ }^{27}$ The first business plan of the Propaganda Ministry, issued on Ist October 1933, included only a small literature division as part of the department for active propaganda. Its director, Dr. Heinz Wismann, was, however, responsible for a number of significant areas, including the 'promotion of national literature; publishing; authors; book groups; public libraries; lending libraries; newspapers; the German Library in Leipzig; the Reichsstelle zur Förderung des deutschen Schrifttums. ${ }^{28}$ The inclusion of the last in the plan was anomalous, given that it was financially dependent on the Propaganda Ministry, but not part of it. On Ist October 1934, Wismann's literature division was finally established as an independent department for literature in the RMVP. In spite of its broad field of operation, however, with only three consultants the department remained on a weak footing in the Ministry. ${ }^{29}$

The close association of the Department of Literature with the Reichsschrifttumskammer (RSK), a division of the Reichskulturkammer (RKK) and the most powerful institution in the politics of literature in the Third Reich, also limited its field of operation. It might have been

David Welch, The Third Reich: Politics and Propaganda (London: Routledge, I993), p. 23.

28 Quoted in Barbian, Literaturpolitik, p. I64. Ibid. 
stronger had Goebbels not been both Propaganda Minster and President of the RKK, which meant his personal influence was not challenged by the strength of the latter. The RKK was established in September 1933 to further German culture and regulate the social aspects of cultural affairs. It was divided into seven divisions, each governed by a president who reported to Goebbels. These were the Reich Chambers for the press, radio, film, literature, theatre, music and fine arts. ${ }^{30}$ Literature was therefore closely associated with the overall body governing cultural activity in the Third Reich, and thus part of the wider programme of cultural control and propaganda.

The RSK was in turn an umbrella organisation for a number of smaller groups. Its competencies, overlapping with those of the Department of Literature, included the practical control of writers and reading material, and the production of books. It therefore played a central role in literary censorship. Promoting German culture in accordance with the directions of the Propaganda Minister, it was also designed to ease relations between the various interest groups within the book trade, ensuring equal economic and social conditions for its members and the avoidance of unnecessary conflicts in the literary sphere. ${ }^{31}$ Membership of the RSK was obligatory for all those involved in the production of the written word, the suitability of each individual being judged on their professional activities and racial background. ${ }^{32}$ The exclusion of a writer from the RSK therefore

'Das Reichskulturkammergesetz', 22nd September 1933, in Michaelis and Schraepler (eds), Ursachen und Folgen, pp. 501-502.

Draft description of the RSK, probably intended for the Handbuch der Deutschen Kunst, produced by Willy Dressler in Berlin around 1940, B.Arch.R56V-48.

32 Ibid. On the rules and debate over membership of professional organisations, including the RSK, see also Dr. Greiner of RMVP to the President of the RSK, 17.9.1938, B.Arch.R56V-51; Wilhelm Baur, Secretary of the RSK, to Reichsminister für Volksaufklärung und Propaganda, 28.8.1940, B.Arch.R56V-5I; Memorandum from RSK to Reichsminister für Volksaufklärung und Propaganda regarding 'Die Beteiligung der Partei bei der Prüfung der Zuverlässigkeit von Mitgliedern', End of May, I938, B.Arch.R56V-5I; 'Mitteilung der Reichsschrifttumskammer, Gruppe Buchhandel an die Reichsschrifttumskammer, Berlin. Betr. Anfrage des Herrn Reichsminister für Volksaufklärung und Propaganda über die Beteiligung der Partei 
theoretically meant a prohibition on the legal publication of his or her work. In practice, however, the enormous bureaucratic machinery required to administer such an ambitious control mechanism meant that some writers slipped through the net. In addition, membership of one of the other chambers within the RKK often enabled publication; August Winnig was, for example, a member of the Reichspressekammer not the RSK. ${ }^{33}$ As membership of two chambers was prohibited, he was nonetheless able to publish his literary works.

While the business of the RSK was executed by bureaucrats, the prominent positions were occupied by literary personalities, largely representing völkisch, Blut-und-Boden tendencies in German literature. In November 1933 Hans Friedrich Blunck was appointed President. Both he and his successor, Hanns Johst, had had some success as writers prior to 1933 and were connected to völkisch-nationalist circles. Moreover, the body of men serving on the Präsidialrat of the chamber continued to include significant völkisch-nationalist representatives over the years. In addition to the original president, Blunck, the founding board consisted of Hanns Johst, already a member of the NSDAP, the publisher Friedrich Oldenbourg, the retailer Theodor Fritsch Jr., Hans Grimm, and finally Heinz Wismann representing the Propaganda Ministry. ${ }^{34}$

In addition to the RSK and the Propaganda Ministry, cultural and literary matters within the Nazi Party itself were directed by Alfred Rosenberg. According to the picture Cecil paints of him, Rosenberg

bei der Prüfung der Zuverlässigkeit von Mitgliedern', 3.6.1938, B.Arch.R56V-5I; RSK to Reichsminister für Volksaufklärung und Propaganda. Betr. Anfrage des Herrn Reichsminister für Volksaufklärung un und Propaganda über die Beteiligung der Partei bei der Prüfung der Zuverlässigkeit von Mitgliedern' 7.6.1938, B.Arch.R56V-5I. Finally on racially ambiguous cases, see, for example, letter from Friedrich Bethge, Gaukulturwart and Intendant des Frankfurter Theaters, to Hans Hinkel in the RSK, 28.7.1936, regarding possible RSK membership for the playwright Gottfried Stein, and temporary membership of the Reichstheaterkammer for Joachim Gottschalk, both of whom had Jewish wives, B.Arch.R56I-3.

33 Grimm and Co. to Rust, November 1934 in DLA - A: Grimm, Grimm to 'Deutschland, Deutsches Reich, Ministerium für Volksbildung'. 
idolised Hitler, and genuinely subscribed to the ideals he professed in his work, in particular his concern with the relationship between Judaism and Christianity and the replacement of the latter with a Germanic religion. ${ }^{35}$ He presented himself as the founder of a National Socialist canon of literature, his early journalistic work for the Party being consolidated with the publication of Der Mythos des zwanzigsten Jahrhunderts in $1930 .{ }^{36}$ In the latter, he was not only influenced by völkisch thinking, but contributed to the corpus of völkisch literature himself. This book bears unmistakable similarities to Houston Stewart Chamberlain's earlier Die Grundlagen des I9. Jahrbunderts. ${ }^{37}$ In spite of the closeness of his ideological position to the völkisch-nationalist worldview, however, he was unpopular among many völkisch-nationalist writers, for whom he was neither able nor apparently willing to help in the achievement of their goals. In spite of his influence over Party ideology, strengthened by the founding of the KfdK before 1933, he also failed to gain a foothold in the highest echelons of the Party hierarchy before April 194I, when he became Minister for the Conquered Eastern Territories. ${ }^{38} \mathrm{He}$ never succeeded in exploiting the full potential of his position in the nationalist literary sphere as the leader of the KfdK and the Reichsstelle zur Förderung des deutschen Schrifttums. ${ }^{39}$

The last was founded in 1933 to evaluate and deploy German literature in the struggle to free the Volksgemeinschaft from the cultural and intellectual legacy of the Weimar Republic. Its lack of success lay largely in the fact that its fields of interest conflicted with those of the RSK under Rosenberg's long-standing rival Goebbels. ${ }^{40}$ Moreover it was neither registered as

Robert Cecil, The Myth of the Master Race: Alfred Rosenberg and Nazi Ideology (London: Batsford, 1972), pp. I-4.

36 'Lebensbeschreibung' Alfred Rosenberg, B.Arch.NS8-ı I.

37 Alfred Rosenberg, Der Mythos des zwanzigsten Jahrbunderts: Eine Wertung der seelisch-geistigen Gestaltenkämpfe unserer Zeit (Munich: Eher, 1930. Edition used: Munich: Eher, 1933).

38 It seems that Rosenberg's late advancement within the party was linked to his failure to gain the personal liking of Hitler. Cecil, The Myth of the Master Race., pp. I05-133.

39 Cecil, The Myth of the Master Race, pp. II3-II5; Ketelsen, Literatur im Dritten Reich, p. 29I.

40 Barbian, Literaturpolitik, p. 285. 
a private organisation nor recognised as an official party organ. Without the support of the Propaganda Ministry, it lacked both funds and a defined purpose. This problem was only partially solved in 1934 when Rosenberg was appointed the Führer's Beauftragte der gesamten geistigen und weltanschaulichen Schulung und Erziehung der NSDAP on 6th June. Thereafter, the KfdK, the Reichsverband Deutsche Bühne and the Reichsstelle were amalgamated under his leadership in the NS-Kulturgemeinde. The new organisation was intended to govern cultural life within the Nazi Party. It nonetheless still bordered too closely on Goebbels' sphere of influence for it to play a strong role in the literary sphere. ${ }^{41}$ Its competencies were also encroached upon by Phillip Bouhler's Parteiamtliche Prüfungskommission zum Schutz des NS-Schrifttums (PPK). Unlike Rosenberg's organisation, the PPK had a clear mandate from the Party. The manoeuvring of the leaders of the two organisations to gain the upper hand continued until the end of the Second World War. ${ }^{42}$ Likewise, the rivalry between Rosenberg and Goebbels remained unresolved to the end. ${ }^{43}$

\section{The Säuberungsaktion to Cleanse German Literature}

No event in 1933 exemplified the aggressively völkisch-nationalist atmosphere in Germany that accompanied the Nazis' Machtergreifung more clearly than the 'Day of the Burning of Books' on ioth May. This was part of a four-week initiative by students against the 'un-German' spirit believed

4I For a more detailed account of the development and activities of the RFdS see Barbian, Literaturpolitik, pp. 270-280.

42 On the Reichsstelle zur Förderung des deutschen Schrifttums and the Parteiamtliche Prüfungskommission, see Barbian, Literaturpolitik, pp. 280-285.

43 This rivalry is evident in the diaries of the two men. See, for example, Fröhlich (ed.), Die Tagebücher von Joseph Goebbels, 27.2.1942, part II, vol. 3, pp. 381-382; Hans-Günther Seraphim (ed.), Das politische Tagebuch Alfred Rosenbergs (Munich: Musterschmidt, 1964), pp. I08-I09. 
to have infiltrated German life. The initiative was taken by the apparently respectable Deutsche Studentenschaft, which was eager to outflank its Nazi rival, the Nationalsozialistischer Deutscher Studentenbund, in its zeal for the new regime. ${ }^{44}$ The principles behind the students' actions were outlined in a statement of twelve points issued by the Deutsche Studentenschaft on 13th April 1933. ${ }^{45}$ They were concerned with the protection of the German Geist in the universities and stated that the roots of language and the written word were in the Volk. In the preceding years a gulf was felt to have developed between the German people and literature, a gulf that had to be closed through the efforts of true Germans. The Jews were held responsible for this situation. Although Jewish writers might write in German, they could think only as Jews. ${ }^{46}$

In Berlin, students and other sympathisers burnt the works of twentyfour 'undesirable and pernicious' authors on a bonfire on the Opernplatz, near the university. A press report described the occasion: 'During the burning of books the SA and SS bands played patriotic tunes and marches, until representatives of the Studentenschaft, to whom the works were allocated according to specific categories, committed the books of the un-German spirit to flames, accompanied by striking words. ${ }^{37}$ The list of authors whose works were condemned to the flames included Marx and Kautsky, Heinrich Mann, Ernst Gläser, Erich Kästner, Friedrich Wilhelm Förster, Sigmund Freud, Emil Ludwig, Walter Hegemann, Theodor Wolff, Georg Bernhard, Erich Maria Remarque, Alfred Kerr, Kurt Tucholsky and Carl von Ossietzky, each representing one aspect of the perceived degeneration of German culture in Weimar Germany. Erich Kästner even

44 See Ian Kershaw, Hitler, 1898 -1936: Hubris (London: Penguin, 1998), p. 483; see also Gerhard Sauder, Die Bücherverbrennung (Munich/Vienna: Hanser, 1983); Richard Evans, The Coming of the Third Reich (London: Penguin, 2003), pp. 426-43I.

45 Twelve Points of the Deutsche Studentenschaft, 13th April 1933, in Michealis and Schraepler (eds), Ursachen und Folgen vom deutschen Zusammenbruch, vol. IX, pp. $486-488$.

46 Ibid.

47 Press report on the book burnings in Michaelis and Schraepler (eds), Ursachen und Folgen, vol. IX pp. 487-488. 
watched his own books being burnt in the pageant that Bramsted has aptly described as an 'orgy of exorcism. ${ }^{48}$

The Nazis in general, and Goebbels in particular, were only too happy to identify themselves with the action. When the proceedings reached their height, the new Propaganda Minister appeared and attacked the Weimar Republic in a speech that was relayed across the nation on the radio. National Socialism, Goebbels declared, sought to give all classes one overriding German identity. The revolution of the Nazis was therefore cultural as well as political and economic, heralding the resurrection of the German spirit through which the nation should be united. ${ }^{49}$ Nonetheless, the fact that it was started by 'non-Nazi' students and was not seriously opposed by the universities and state officials reinforces the view that völkisch thinking was widespread in the Bildungsbürgertum. Goebbels' speech was, therefore, both a demonstration of his skill in harnessing existing sentiments to the Nazi regime and an announcement of Nazi policy towards the literary sphere in the months that followed. In all, twenty thousand books were destroyed in one night, heralding a new phase in German literary history: the state would now decide what was 'good' and what was 'bad' literature. German writers were obliged to subordinate themselves to the good of the nation, a sentiment Goebbels summed up three years later in his speech at the opening of the annual Week of the German Book in Weimar on 25th October 1936, when he declared: 'Now the pen has been compelled to serve the nation like the sword and the plough. ${ }^{50}$

Grimm's post-1945 reflections on these events noted that, as far as he had been aware as a member of the Prussian Academy of Arts, the book-burnings had not been instigated by the state. He played down both their significance and the extent to which they had spread across Germany, presenting them as isolated instances, the private enterprises of 'a few confused minds', desirous of recognition, who burned the contents

48 Ernest K. Bramsted, Goebbels and National Socialist Propaganda, 1925-1945 (Ann Arbor: Michigan State University Press, 1965), p. 68.

49 Joseph Goebbels' Speech, I0.05.1933, in H. Heiber (ed.), Goebbels Reden: Band I, 1932-1939 (Düsseldorf: Droste, 1971), p. 109.

so Quoted in Bramsted, Goebbels and National Socialist Propaganda, pp. 68-69. 
of their own and friends' libraries. These events, he maintained, had then been blown out of proportion by the Allied occupiers after the Second World War. He added that after 1945 , similar efforts to remove books from circulation were instigated by the Allies; events like the Day of the 'Free Book' held in East Berlin on Ioth May 1946 far outstripped any actions seen during the Nazi years. Grimm concluded by stating that he had never seen the list of banned books that the Propaganda Ministry was supposed to have introduced in the later years of the Second World War; as far as Grimm was concerned, it had been possible to buy any German book of 'literary value' as long as the buyer was known to the salesperson. ${ }^{51}$

Albeit selective, Grimm's account still reflects the limitations of initiatives taken against 'undesirable' literature in the Third Reich. In practice the apparently revolutionary nature of the Bücherverbrennungen stood in sharp contrast to the organisational process behind the scenes. In fact, while censorship was quickly introduced following the Nazi Machtergreifung, it was some time before a workable system developed. The early work of compiling blacklists and establishing a system to 'cleanse' German literature of the 'un-German Geist' was a process of trial and error. In the first years of the Third Reich, a lack of central coordination was also evident.

The compilation of blacklists in the Third Reich took place on a regional and institutional level. In Hamburg, the staff of the Öffentliche Bücherhalle, led by Dr. Wilhelm Schuster, demonstrated early awareness of the demands of the new regime. The minutes of the meeting of directors on 18 th March 1933 record a positive attitude to the task ahead and a high degree of preparedness:

The public library has to serve the entire Volk and to incorporate all in the development of essential and constructive intellectual currents. As these first found their downfall in literature, in the same way the stocks of books will become a mirror of the new intellectual movement. A perusal of the acquisitions of the last two years has fully confirmed this, in that the literature of the new Right was already acquired by the libraries on its appearance and as a result is available to the broadest mass of 
people. The political change of 5 th March demands the removal from the holdings of such works that could be detrimental to the new will of the nation. ${ }^{52}$

The minutes of the same meeting went on to announce a discussion concerning the removal of unacceptable books from library collections. In the wake of the Reichstag fire, blamed by the Nazis on the Communists, and the elections of 5 th March, most of those works included on the early lists were Marxist, pacifist or anti-religious. Entries for these books were to be removed from library catalogues or, where they appeared alongside other publications, crossed out. While the removal of the works was not emphasised in public, neither was it hidden. The instructions concluded by saying that public enquiries about these books should be met with a matter of fact statement that they had been removed and complaints dealt with at the discretion of the librarians. ${ }^{53}$

In Berlin in April 1933 the Ausschußzur Neuordnung der Berliner Stadtund Volksbüchereien also compiled blacklists. The committee worked its way through various categories, listing books to be removed from the city's libraries. The subject areas included politics, art, history, literary history, geography and biography. In setting out to struggle 'against the signs of corruption in our thought and lives, that means against the Asphaltliteratur, written predominantly for city people and designed to uproot them and confirm them in their alienation from their environment, from the Volk, and from any sense of community, ${ }^{54}$ it echoed völkisch-nationalist ideals. Initially these lists were only valid in Berlin, but in May 1933 they were adopted by the Prussian Ministry of Culture for several public libraries in Prussia. They were the first indexes of banned books in the Third Reich and their use by the students in the 'Aktion wider den undeutschen Geist' meant that they were quickly disseminated beyond the boundaries of Prussia.

In adopting libraries as one of the focal points in their efforts to cleanse German literature in the Third Reich, the Nazis adopted a pragmatic Hamburg, 18th March 1933, Hamburger Staatsarchiv: 614 - I/38.

53 Ibid.

54 Quoted in Barbian, Literaturpolitik im 'Dritten Reich', p. I42. 
approach to the problem of censorship. While their aim was to remove all traces of 'un-German' literature in German society, they began by seeking to limit the circulation of books identified as such. Even with a system of secret police and informers, it was impossible to police the reading habits of every German. Libraries, however, were by their very nature centres where one copy of a work could achieve wide circulation. It was also relatively simple to bring them under state control. They therefore received special attention.

In Thuringia, a censorship apparatus was developed that was intended as a model for the whole Reich. On 28th August 1933, the Thüringisches Volksbildungsministerium issued a set of guidelines for the cleansing of libraries. These declared that libraries needed to regard national renewal as their most important task. This would only be achieved through the purging of their holdings according to 'volksbiologische und nationalpolitische' principles. In the case of so-called 'Schöne Literatur' therefore,

The primary selection criterion must be: Only poets and writers who stand on the foundation of the Volksgemeinschaft defined by blood and type and feel themselves to be one with the fate of their Volk in their intellectual-spiritual position, belong in the German library. Works must be judged not only according to their form and literary worth, but at the same time, and in cases of doubt primarily by the compatibility of their character with the Volk and the value of their point of view. ${ }^{55}$

In contrast to the Hamburg and Berlin lists, moreover, in addition to removing the literature of Marxist, Communist and Jewish writers, the Thüringisches Volksbildungsministerium also explicitly adopted the völkisch-nationalist antipathy against the 'spirit of the decadent, bourgeois subjectivity of literati foreign to the Volk, living in cities far from their native landscape ${ }^{56}$ Finally the works of non-German writers were only to be retained where they reflected the 'Nordic spirit.' These principles were

55 'Vorläufiges Richtlinien für die Auslese der Bestände der öffentlichen Büchereien nach völkischen Gesichtspunkten', Amtsblatt des Thüringischen Ministerium für Volksbildung, Jahrgang I2: Weimar, den 26. September, Nr.15, 1933, pp. 143-144, B.Arch.R56V-72. Ibid. 
also applied to academic and scientific literature, in which, for example, works that reflected the democratic spirit of the Weimar Republic were to be removed as outdated, as were those that in any way expressed the ideals of the Enlightenment. ${ }^{57}$

Like libraries, bookdealers were also targeted by the Nazis in their efforts to gain control over the reading material available to the German public. This was carried out through a working committee composed of representatives of the Reichsverband Deutscher Schriftsteller (RDS), the book-trade, public libraries, the KfdK, as well as several literary personalities. On I3th July 1933 it presented the first results of its work to the Ministry of Propaganda: a list of 'Schöne Literatur' by those authors whose works should be removed from the traffic of books in the book-trade. ${ }^{58}$ The statement accompanying the list promised a second list of 'Schöne Literatur für Volks- und Leihbüchereien' within days and declared that work had already begun on a further list 'Wissenschaft, politische Schriften etc.' Also included was a report on the way the process had been carried out. The Party was not, it declared, required to provide reasons for censoring a particular work to satisfy individual citizens; its only duty was to serve the interests of the German Volk. The Volk had its roots in history and represented an ultimate truth, which was upheld by Nazi censorship. This was not designed to protect the peace of bourgeois existences, but to protect the fundamental existence of the Volk, to which every legitimate member of the German state belonged. ${ }^{59}$

Finally the RSK also maintained its own lists of 'schädliche und unerwünschte' literature consisting of works that contradicted the political and cultural goals of the Nazi Reich. ${ }^{60}$ These were also applied in Austria and the

57 Ibid.

58 Report accompanying initial black list presented by the working committee to the RMVP on 13.7.1933, B.Arch.R56V-70.

59 Ibid.

60 On I5th April 1940, the RSK issued a declaration regarding the censhorship of works which stated that the earlier declaration of 25 th April 1935, published in the Völkische Beobachter on 8th May the same year, was also valid for the newly conquered Eastern Territories, B.Arch.R56V-48. 
Eastern occupied territories in the late 1930s and during the Second World War. It was forbidden to publish, sell, distribute, lend, loan, exhibit, advertise, or possess these works. In addition the RSK maintained a separate list of works unsuitable for young people that were neither to be available in libraries nor exhibited in shop windows nor sold or supplied to anyone under i 8 years of age. These lists were presented as protection for German youth, drawing on the laws against Schmutz-und Schundliteratur in the Weimar Republic. They were, however, also issued in conjunction with the establishment of comprehensive youth organisations and therefore intended to ensure that the next generation would only be exposed to literature compatible with Nazi ideology. Finally, the RSK also banned all works by Jewish and half-Jewish writers, whether they appeared on the lists or not. Breaching these rules would lead to exclusion from the RSK, a serious consequence for booksellers who were not allowed to practice their trade if they were not members. ${ }^{61}$

In the early years of the Third Reich Nazi rhetoric emphasised the exclusion of Jews not only from the RSK, but also from all literary organisations, including the German branch of the PEN Club. ${ }^{62}$ In practice, however, this was less clear-cut and there was some discussion among leading Nazis about the role of Jews in German literary life. The Schriftleitergesetz of the 4th October 1933 contained no explicit 'Aryan' clause, adding to the confusion about the way Jewish authors should be treated. Hans Grimm pleaded that Jews who wrote and whose work conformed to Nazi regulations, should be admitted to the RSK and allowed to practice their art. RSK President, Hans Friedrich Blunck, adopted the same opinion, writing to Grimm on 20th November 1933: '[...] unjust treatment of Jewish fellow citizens who distinguished themselves in the war, who have stood firmly in favour of our state and have not taken part in the propaganda of decadence, must be avoided under all circumstances $[. ..] .^{63}$ It is likely that this conciliatory attitude towards Jewish writers, alongside the fact that he was not a member of

6I Anordnung betreffend Listen des schädlichen und unerwünschten Schrifttums. (Verkündet im Völkischen Beobachter vom 21.5.1940; Börsenblatt für den deutschen Buchhandel Nr. 117/1940.), B.Arch.R56V-48.

62 Blunck to Staatskommissar Wienhold, I.5.1933, B.Arch.R56I-5.

63 Quoted in Barbian, Literaturpolitik, p. 366. 
the Nazi Party, cost Blunck his post as President of the RSK in I935. At the end of May of that year, Wismann reported to Goebbels that the number of 'non-Aryan' writers in the RSK had been reduced to five. Nevertheless, 619 'non-Aryans' were still active in the book trade. ${ }^{64}$ In 1938, moreover, there was still considerable concern about the second-hand books from 'liquidated' Jewish households making their way back onto the book market, which proved very difficult to control. ${ }^{65}$

By the beginning of 1935, with some exceptions, the work of cleansing German literature within the borders of the Reich was drawing to an end. On Ist January 1935, Dr. Heinl of the RSK reported that in Berlin the action had gone relatively smoothly. Of the 28,000 books to be removed from library collections, 21,000 had been delivered to the official depots, where they were disposed of under Party supervision. Overall, Heinl went on, the action had met with little resistance, although a few libraries had sold the banned books, and he projected a success rate of $85-90$ per cent. ${ }^{66}$ On 8th January he reported that of a total of 5,000 libraries in the whole Reich, 3,875 had presented lists of the works in their collections that were no longer considered suitable for public consumption. Of these 3,290 had been checked by Party officials, leaving I,I25 to be handed in and a total of I,7 Io to be checked. ${ }^{67}$ While books continued to be removed from circulation, from this point on, Nazi leaders increasingly turned their attention to maintaining the authorised canon of German literature by controlling the production of new books rather than the removal of those already in circulation. There was also increased concern about books being brought into Germany from abroad. ${ }^{68}$

64 Barbian, Literaturpolitik, p. 37 I.

65 See corrrespondence concerning the control of second-hand bookshops with regard to second hand books from Jewish households in B.Arch.R56V-196.

66 Dr. Heinl, Referent in der RSK, 'Bericht über die Säuberungsaktion der Leihbüchereien am I. Januar 1935', B.Arch.R55-682.

67 Dr. Heinl, Referent in der RSK, 'Bericht über die Säuberungsaktion der Leihbüchereien am 8. Januar 1935' in B.Arch.R55-682.

68 For lists ca. 1937, especially of books imported into Germany from other countries, see: B.Arch.R56V-7I. 
In spite of assertions of success, there were numerous inconsistencies in the censorship system and several writers managed to slip through its holes. Crucially, Nazi censorship was largely concerned with banning books rather than authors. The appearance of the work or works of particular authors in the lists of 'schädliches und unerwünschtes Schrifttum' did not necessarily mean that they were banned altogether. Often writers continued to work as usual, others were permitted to continue publishing under pseudonyms, while some found alternative employment as scriptwriters or journalists. The authorities guarding literature in the Third Reich were not therefore so much concerned with banning writers, unless they were Jewish, as controlling their output. ${ }^{69}$

It was also possible for bans on the work of particular authors to be lifted. For example, on 3 ist October 1935 six works by Waldemar Bonsels were included in the index but did not figure at all on the list made public on 3ist December 1938. The reason given for this turn-around by the RSK was the good effect his works were having abroad. As a result, and given Bonsels' preparedness to conform to the requirements of the regime, it was decided that no further obstacles should be placed in his path. Rosenberg's Reichsstelle also agreed to this decision, although reservations concerning Bonsels remained. $^{70}$

Ernst Wiechert provides another example of the changeable nature of Nazi attitudes to specific writers, illustrating the fine line they trod between not upsetting public opinion and gaining control over literary production. Their treatment of him shows the ongoing juggling between threats and incentives that the Nazi leaders were forced to undertake in running the politics of literature in the Third Reich. Wiechert's lecture on the existential conflict of writers with the Nazi leaders, delivered at the University of Munich in April 1935, was held under the auspices of the KfdK. Der Dichter und die Zeit was a clear denunciation of Nazi cultural politics and the speech was never printed in Germany, although it later

69 Barbian, Literaturpolitik, p. 368. See also Cuomo, 'Hanns Johst und die Reichsschrifttumskammer', p. I20.

70 Barbian, Literaturpolitik, pp. 4II-4I2. 
gained considerable attention abroad. ${ }^{71} \mathrm{~W}$ iechert was allowed to continue lecturing, but his later speeches were closely monitored by the Gestapo. He was also denied permission by the RSK to undertake a lecture tour abroad, and the Langen-Müller Verlag rejected his 1937 novel, Der weibe Büffel oder Von der groben Gerechtigkeit, an anti-despotic tale. He nevertheless presented it in Cologne and elsewhere, as part of his continued activity against the Nazi regime. Eventually the authorities lost patience and Wiechert was arrested on 6th May 1938. His imprisonment was also intended as a warning to other writers who might be inspired by his example. In July he was sent to Buchenwald and was only released two months later after promising to stop criticising the regime. Following his release, however, everything was done to aid the publication of his future works, and in 1939 the Langen-Müller Verlag published his novel, Das einfache Leben. Wiechert remained under close observation, but as long as he withheld his political views he was allowed to work, and his books continued to appear in relatively high numbers up to the end of World War II. ${ }^{72}$

\section{Promoting 'German' Literature}

While the 'cleansing' of the German literary canon of Marxist, Communist and other books in direct opposition to the regime, as well as those of Jewish writers, was underway, the Nazis were faced with the corresponding challenge of identifying and promoting the literature that should represent the new Germany. As part of the cleansing of the libraries, the Nazi authorities issued lists of works to guide librarians in replenishing the stocks of the libraries after the 'unerwünschte und schädliche' books had been removed. The lists were produced by various institutions. In Thuringia as early as

7I Ernst Wiechert, Der Dichter und die Zeit: Rede gehalten am I6. April im Auditoium Maximum der Universität München (Zurich: Artemie-Verlag, 1945).

72 Barbian, Literaturpolitik, pp. 399-403. 
May 1933, Kurd Schulz, the director of the Landesberatungsstelle für volkstümliches Büchereiwesen und Jugendschrifttumspflege, began to encourage libraries to acquire copies of Mein Kampf..$^{73}$ From the end of December of the same year, the Volksbildungsministerium began to produce 'golden' lists of books that should be held in library collections.

The first 'golden' list was published in the Amtsblatt des Thüringischen Ministeriums für Volksbildung on 2nd March 1934, and included a relatively broad selection of 'German' literature. ${ }^{74}$ Alongside writers like Heinrich Anacker, Hans Friedrich Blunck, Hans Grimm, Hanns Johst and Thor Goote, who, at least initially, openly supported the regime, it included völkisch and nationalist writers of earlier generations such as Moeller van den Bruck, Felix Dahn, Adolf Bartels, Artur Dinter and Gustav Frenssen. In addition the names of several writers, notably that of Ricarda Huch, stand out because they had already spoken out against the regime. A separation was therefore made between their personal opinions and the nature of their works. Overall, the emphasis was on ensuring the canon of German literature was sufficiently German. As a result, German mythology, like the Edda and the Nibelungenlied, and the works of 'classic' authors like Schiller and Goethe, Achim von Arnim and Kleist, as well as nineteenth century liberal-nationalists like Gustav Freytag, and the Heimatliteratur of writers such as Hermann Löns also featured on the list. ${ }^{75}$

While a blind eye was sometimes turned on writers whose attitude to the regime was ambiguous, on the whole the relationship of the writer to the Volk and the effect his or her books would have on the public were more important in the compilation of these lists than the quality of his or her work. This is underlined in the guidelines produced by Dr. Friedrich Lampe for the Hamburger Öffentliche Bücherhalle in January 1934. He emphasised that the artistic merits of a particular work were less important

73 Barbian, Literaturpolitik, p. I46.

74 'Aufbau der Bestände der öffentlichen Büchereien nach völkischen Gesichtspunkten', Amtsblatt des Thüringischen Ministeriums für Volksbildung, I3. Jahrgang, Weimar, 2nd March 1934, pp. 32-39. Ibid. 
than its ideological content and potential for propaganda purposes. $\mathrm{He}$ declared that, in selecting books, it was necessary

to be constantly conscious that the standard for assessment for the public libraries is not absolutely aesthetic, but one of popular education; as a result works that are artistically very pure but which are accessible to only a small readership, or perhaps due to their intellectual position are even rejected for reasons concerned with the education of the Volk [...]. Only a small number of readers is capable of appreciating the artistic in a novel, most stick to the subject matter and the problems presented therein and their practical moral for their own life. The library must now cater for them. Nonetheless, one thing should never be forgotten: a lowest limit must never be crossed: the weaker artistic works should also at least be real; anything kitsch, emotionally false, that distorts reality or is directed solely at suspense should be avoided where possible. ${ }^{76}$

This was in line with the task of the Volksbücherei as it was outlined by Dr. Krebs at the 37 th meeting of the directors of the Hamburg public libraries on 16th October 1934. He emphasised the Führungsaufgabe of the libraries, which meant that they should be influencing rather than catering for the reading tastes of the German public: librarians were to steer the public towards books that would educate them regarding the National Socialist regime. ${ }^{77}$

The Nazis also went to considerable lengths to promote the works of established authors who placed themselves at the disposal of the regime. Among them was Adolf Bartels, whose work was well received in the Third Reich, where he was honoured as a Vorkämpfer of National Socialism. Some commentators, Fuller included, have suggested that although he was awarded many accolades, including an honorary doctorate from the University of Leipzig and, in 1937 , the Adlerschild des deutschen Reiches, ${ }^{78}$ the Nazis did not allow him to participate actively in the German state.

76 Dr. Friedrich Lampe, Gesichtspunkte für die Anfertigung von Bücherbesprechungen, January 1934, Hamburger Staatsarchiv: 6I4 - I/38.

77 Protokoll der 37. Leitersitzung der Öffentlichen Bücherhallen, Hamburg, Hamburger Staatsarchiv, 6I4- I/38.

78 Schoeps, Literatur im Dritten Reich, p. 37. 
He never became a full member of the Nazi Party. ${ }^{79}$ The re-publication of most of his works after 1933, along with numerous commentaries and dissertations on them, suggest, however, that his contribution to the regime should not be underestimated. The Nazis were more than happy to use him as part of their attempt to give the regime roots in the culture of previous generations. In the end, it is most likely that the main impediment to Bartels' more active participation in the cultural and literary life of the Third Reich was his age. In 1933, when the Nazis came to power, he was already $7 \mathrm{I}$ and in poor health.

The influence of Bartels' literary criticism on literary thought in the Third Reich was clearly demonstrated in Gerhard Baumann's Jüdische und völkische Literaturwissenschaft: Ein Vergleich zwischen Eduard Engel and Adolf Bartels, ${ }^{80}$ published by the Eher Verlag in 1936 . Baumann, a minor party official, explained that he had come across Bartels' work while he was working as leader of a local group of the Nationalsozialistischer Schülerbund. This, he said, led to his awakening with regard to Eduard Engel's literary history. In his Geschichte der deutschen Literatur von den Anfängen bis in die Gegenwart, Engel placed particular emphasis on the importance of language for the völkisch identity. ${ }^{81} \mathrm{He}$ was best known, both by his detractors and his admirers, for his campaign against the use of foreign words in German literature.

It therefore seemed surprising to Baumann that Bartels labelled Engel a Jew, a label that stuck although there appears to be no evidence to support this conclusion. According to Baumann, influenced by Bartels, this was clear simply on a closer examination of Engel's book:

In this book [Jüdische Herkunft und Literaturwissenschaft] I came across a section on Eduard Engel. I knew his two-volume history of German literature, and I had flicked through its pages several times without knowing that the author was a Jew.

79 Fuller, The Nazis' Literary Grandfather, pp. 175-177.

80 Gerhard Baumann, Jüdische und völkische Literaturwissenschaft: Ein Vergleich zwischen Eduard Engel and Adolf Bartels (Munich: Eher, 1936).

8I Eduard Engel, Geschichte der deutschen Literatur von den Anfängen bis in die Gegenwart, 2 Volumes (4th Edition, Leipzig: Freytag, 1908). 
On the contrary, I believed Engel to be a good German and was quite astonished to hear from Bartels that Engel was a Jew. After that I took a closer look at Engel's literary history and above all examined his remarks about those poets and writers whose works I knew, for example Bartels, Chamberlain, Heine etc. Then my eyes were opened and I knew whose intellectual child Engel was. ${ }^{82}$

Engel's alleged crime was twofold: First, he proved his Jewish ancestry by deriding good German authors like Bartels and Chamberlain, and defending Jewish writers like Heine. Second, he tried to disguise his background by campaigning against the adoption of foreign words in German literature and posing as a völkisch literary historian. According to Baumann, Bartels recognised that the true danger to German literature was not the use of foreign words, but the Jews undermining German culture from within. ${ }^{83}$

The case of Gustav Frenssen provides another example of the positive reception of older völkisch-nationalist writers in the Third Reich. Following a slump in his career during the Weimar Republic, during which he briefly flirted with republicanism, Hitler's coming to power coincided with an upturn in Frenssen's fortunes. Frenssen's conscious efforts to gain the acceptance of the Nazi rulers paid off. The ideological and anti-clerical nature of the works he wrote after 1933, most significantly Der Glaube der Nordmark, ${ }^{84}$ ideally suited the needs of the Party. As a result, this work was commonly bought and presented by the Party to members of the $\mathrm{HJ}$ and BDM on the occasion of the Jugendweihe; a substitute Bible for the Nazis' substitute confirmation. This accounts in part for its success: between its appearance in 1936 and 1938,25 editions, totalling 100,000 copies, appeared, and by the end of the war the figure was at least 350,000 copies. ${ }^{85}$ While this success benefited Frenssen financially, it is impossible to assess how many of those who received a copy actually read the work. Newspaper reviews, moreover, offer only biased evidence of the reception of Frenssen's works. With the exception of evangelical circles, and the Deutsche Christen, who

82 Baumann, Jüdische und völkische Literaturwissenschaft, p. 5.

83 Ibid. pp. 7-Io.

84 Frenssen, Der Glaube der Nordmark (Berlin: Truckenmüller, 1936).

85 Crystall, Gustav Frenssen, p. 499. 
expressed, in so far as they were able without arousing the displeasure of the Party, strong opposition to Frenssen's anti-Christianity in these years, most publications reproduced the Nazi Party's positive reaction to his writing. ${ }^{86}$

\section{Literary Prizes}

Literary prizes also played a significant role as tools used to promote suitable literature. They were intended to encourage German writers to produce works for the Third Reich and to contribute to drawing proven authors into the literary establishment of the regime. At the same time they also provided a source of financial support for writers, and offered the organisations and individuals who awarded the prizes the chance for publicity and self-promotion. Award ceremonies, moreover, provided an opportunity for cultural propaganda. While large cultural events allowed Nazi leaders to present the principles of cultural life in the Third Reich to the public, award ceremonies were a chance to demonstrate these principles in practice and at the same time to claim specific writers for the regime. The propaganda effect of literary prizes was further enhanced by the publicity they attracted; newspaper articles described the events and presented the lives and works of writers to the wider public, at the same time spreading Nazi values. The award and regulation of prizes was thus an important component in Nazi Literaturpolitik.

Prizes were, however, not new. In the Weimar period they already served as a way for organisations and political parties, as well as press, film and radio corporations, to encourage writers to deal with specific themes and to promote particular political and social issues in the public consciousness. ${ }^{87}$ The adaptation of existing prizes for the cultural policies of the Third Reich, therefore, had the additional advantage of allowing the Nazis to claim

87 Barbian, Literaturpolitik, pp. 450, 458. 
continuity with the longer cultural history of the German Volk. During the Weimar Republic, many literary prizes had furthered republican ideals and those honoured were frequently representatives of the literary modernism abhorred by the völkisch-nationalists and the Nazi Party. After 1933 prizes, like other literary institutions, were either gleichgeschaltet, abolished or newly established. Helga Strallhofer-Mitterbauer has noted that relatively few prizes fell into the first category: she lists the Goethe-Preis in Frankfurt am Main, the Literaturpreis in Munich and the Erzähler-Wettbewerb of the journal Die neue Linie as examples. ${ }^{88}$

The creation of new prizes took place on national, regional and local levels. Considerable weight was also given to literary prizes at the highest ministerial levels. As part of the earliest attempts of the Nazis to inculcate the population with the National-Socialist ideology, and to gain prominence in German life and culture, as well as politics, in July 1933 Goebbels instituted the National Book Prize worth 12,000 Reichsmarks, also known as the Stefan George-Preis, claiming the legacy of the poet who died in Switzerland the same year. The winners of this prize were: 1934: Richard Euringer for Deutsche Passion; 1935: Eberhard Wolfgang Möller for his volume of poetry Berufung der Zeit; 1936: Gerhard Schumann for his cantate Heldische Feier; 1937: Friedrich Bethge for the drama Marsch der Veteranen; 1938: A volume edited by Baldur von Schirach entitled Das Lied der Getreuen. Verse ungenannter österreichischer Hilter-Jugend aus den Jahren der Verfolgung 1933-1937; 1939: Bruno Brehm for his Austrian trilogy Apis und Este, Das war das Ende and Weder Kaiser noch König. ${ }^{89}$

Likewise Hanns Johst was rewarded for his dedicated work for the National Socialist cause with the Deutscher Nationalpreis für Kunst und Wissenschaft in 1938, a prize that was established to replace the Nobel Prize for Literature, which Germans were forbidden to accept following its award to Carl von Ossietzky in 1936. In recommending Johst, Ihde, the Geschäftsführer of the RSK, wrote: Dokumentation (Vienna: Böhlau, 1994), p. I2. 
Hanns Johst is one of very few writers who most seriously sought to follow the political pioneers in his literary work and, clearly rejecting social-national [DNVP] ways of thinking, early on recognised in the teaching of National Socialism the rebirth of Germany. The fundamental principles of National Socialism and the work of the National Socialist movement itself became the redemptive moment for Hanns Johst. From this point his own literary work begins to grow. He lays it at the feet of his Führer in thanks. ${ }^{90}$

Following a commentary on Johst's works, Ihde concluded by assuring a second nomination for Johst from Max Amman, Director of the NSDAP's Eher Verlag, and stating: "Dichter" and human being are unified in Hanns Johst through National Socialism and in this relationship Johst stands alone. Johst's writing always testifies to the most intense experience, and this experience was for him National Socialism. ${ }^{91}$

On a more regional level, for example, as part of the first Kulturwoche in the Gau of Saxony, the Reichsstatthalter, Martin Mutschmann, donated two prizes. The first was to be awarded to a Heimat novel set in Saxony that portrayed the characteristics of the Lausitzer, the populations of the Erzgebirge or the Vogtland, or the Dresdner or Leipziger. The second would be given for a comic drama that revealed the true humour of the German Volk. ${ }^{92}$ Thus, it was hoped a canon of National Socialist literature would emerge. ${ }^{93}$

Moreover, the literary institutions of the Nazi government sought to encourage the donation of prizes from private sources. During his time as President of the RSK, Blunck cultivated several potential benefactors for cultural and literary prizes. Significant among them were the prizes for the works of Auslandsdeutsche, awarded by the foundations established at the end of 1935 by the Hamburg businessman Alfred Toepfer, and his industrialist

90 Ihde to Goebbels, I.07.1938, 'Betr. Deutschen Nationalpreis für Kunst und Wissenschaft 1938 ' in B.Arch.R56V-3I.

9I Ibid.

92 Ibid. pp. $45 \mathrm{I}-452$.

93 For culture and literature prizes see also Jan Zimmermann, 'Von deutschen Jugendherbergen zu europäischen Kulturpreisen' in Georg Kreis et al. (eds), Alfred Toepfer, Stifter und Kaufmann: Bausteine einer Biographie-Kritische Bestandaufnahme (Hamburg: Christians, 2000), pp. 226-229. 
brother Ernst, based in New York. Between them they donated I.25 million Reichsmark for initially eight and later ten prizes each worth between 5,000 and 10,000 Reichsmark. These were administered by two foundations, the Johann-Wolfgang-von-Goethe-Stiftung and the Hansische-Stiftung. ${ }^{94}$ The focus of these prizes corresponded with Alfred Toepfer's particular concern for the status and wellbeing of Germans living outside the borders of the Third Reich. Thus, with the establishment of prizes for Germans in each of Germany's neighbouring regions, and those peoples considered racially related, literature prizes once again reflected and propagated the Nazi ideology. While Blunck was closely involved in the foundation and administration of the prizes as President of the RSK, both Toepfer and the Nazi government went to great lengths to ensure that they retained the appearance of independence from the political arena, which would have weakened their effectiveness abroad. To heighten the image of autonomy from the government, they were awarded through German universities, which also lent them academic prestige. Nonetheless, the selection committees for these awards were heavily influenced by the RSK, and the awards reflected the concern for the 'pan-German' Volk that also informed Nazi attitudes to foreign affairs, as well as an older völkisch emphasis on the Great German Reich. ${ }^{95}$

A number of literary prizes and honours were similarly associated in the first instance with specific universities, or with cities or regions. Identification with a specific locality could also be a reason for choosing a specific writer as the recipient of a prize, as was the case with Wilhelm Schäfer and the Rheinischer Literaturpreis in $1937 .{ }^{96}$ These associations remained strong between 1933 and 1945 . Thus the Rheinischer Literaturpreis

94 For the extensive correspondence between officials in the RSK and Toepfer regarding the establishment and administration of prizes, see B.Arch.R56V-91.

95 Barbian, Literaturpolitik, pp. 46I-462; Zimmermann, 'Von deutschen Jugendherbergen zu europäischen Kulturpreisen', pp. 21I-25I; Helga Strallhofer-Mitterbauer, NS-Literaturpreise für österreichische Autoren: Eine Dokumentation (Vienna: Böhlau, I994, pp. 3I-47.

96 Gertrude Depl-Kaufmann, 'Der Rheinische Literaturpreis 1935-1944' in Bernd Kortländer, Literaturpreise: Literaturpolitik und Literatur am Beispiel der Region Rheinland/Westfalen (Stuttgart: Metzler, 1998), pp. 67-100. 
was established in 1935 on the initiative of the Landeshauptmann of the Rhine Province, Heinz Haake. It was first and foremost a Nazi initiative and remained strongly tied to Party structures throughout its history. It was first awarded at the Rheinische Dichtertagung in Düsseldorf and Krefeld in October of the same year to Heinrich Lersch. Gertrude Cepl-Kaufmann has noted that from the time of the informal foundation of the Bundrheinischer Dichter in 1926 such events had gained substantial significance in the province. She goes on to argue that the prize served the Nazi government as a way of drawing existing institutions and structures into its ideological sphere of influence, noting that of the nine recipients of the prize between 1935 and 1943, only two, Hermann Stegumann and Curt Langebeck, had no apparent connection with the Bund rheinischer Dichter. ${ }^{97}$ From 1937 , the year in which Wilhelm Schäfer was honoured, the prize-giving ceremony was held annually in the Gürzenich in Cologne, taking on an increased Nazi character that reflected not only the intensification of the Party's control over literature prizes by the end of the 1930s but also the manner in which they could be used as instruments as propaganda. ${ }^{98}$

Existing prizes were also deployed in the service of the new regime, emphasising ongoing continuity in German culture. The Gleichschaltung of the Goethe-Prize was swift. In January 1933 writers like Edmund Husserl, Wilhelm Schäfer, Hermann Hesse, Rudolf G. Binding and Martin Buber were under consideration; with the appointment of the Nazi Fritz Krebs as mayor of the city and the simultaneous takeover of the presidency of the prize committee by Bernhard Rust, however, that year's prize was finally awarded to völkisch Hermann Stehr. In the following years, the committee, which after 1934 also included Goebbels and the playwright and Gaukulturwart der NSDAP, Friedrich Bethge, selected, among others, Erwin Guido Kolbenheyer (1937) and Wilhelm Schäfer (194I) as the recipients of this prize. ${ }^{99} \mathrm{~W}$ illi Emrich's account of proceedings on the occasion

98 Ibid., p. 8I.

99 Friedrich Bethge to Hans Hinkel, 28.7.1936, B.Arch.R56I-3; Barbian, Literaturpolitik, pp. 460-46I. 
of Schäfer's award in 1938 remains relatively uncritical. He quotes the formal wording of the award, which stated: 'Die Ehrung gilt dem dichterischen Gestalter deutscher Landschaft und deutschen Volkstums, dem Künder der deutschen Seele und Meister geprägter Sprachform, in dessen Leben und Werk sich der Begriff des Klassischen im Goetheschen Sinn rein und zuchtvoll verkörpert.' ${ }^{100}$ In accepting the award, Schäfer in turn placed significance on the line of continuity it represented from Goethe's genius to the leading writers of the contemporary, Nazi-led era. ${ }^{101}$

Another significant recipient of the Goethe Prize was the East Prussian poet, Agnes Miegel, who had already been honoured with the Herder Prize, as well as a plaque donated by the NS-Kulturgemeinde to be mounted on the house of her birth. In addition, she was a member of the Literature Section of the Prussian Academy of Arts and had received an honorary doctorate from the University of Königsberg by the time she won the Goethe Prize in 1940 , the same year she formally joined the NSDAP. ${ }^{102}$ The reports of her award demonstrate the way in which significant literary prizes had a wider significance in the Third Reich, providing opportunities to spread an ideological message, not least through the press.

In Miegel's case, particular emphasis was placed on the theme of Heimat, which was imbued with particular significance in time of war. Thus, one newspaper commented that in committing her life and work to East Prussia, a region charged from early on in history with a heroic fate, Miegel was expressing her commitment to Germany. ${ }^{103}$ Out of love of the Heimat, and in its hour of need, the role of literature was, therefore, to give expression to the ultimate sentiment: duty to one's Heimat. Agnes Miegel was responsible for making East Prussia, its landscapes and cities, known to Germans throughout the German Reich. Through her ballads and songs,

Io० Quoted in Willi Emrich, Die Träger des Goethepreises der Stadt Frankfurt am Main von 1927 bis 196 I (Frankfurt a/M: Osterrieth, I963), p. I7I.

Ior Ibid., p. I7I.

IO2 'Der Goethepreis I940 für die Dichterin der ostpreußischen Heimat,' undated clipping from an unnamed newspaper (possibly the Volksblatt), 1940, DLA - A: Miegel, 3: Zum Leben und Werk.

IO3 Ibid. 
she connected of the 'new Reich' with centuries past, whilst giving constant expression to the German present and future as only a women with her particular calling could do. The article further noted that she dedicated a number of ballads to those who had died in the Second World War, her poetry bestowing immortalilty on them. ${ }^{104}$

A clipping of a further article that has remained with Miegel's papers, a handwritten note attributing it simply to the General-Anzeiger, emphasised similar themes. The reporter went to particular pains to link Goethe to Miegel, stressing the continuity in the German spirit that the award embodied. ${ }^{105}$ In presenting the award, Oberbürgermeister Staatsrat Dr. Krebs, on behalf of the city of Frankfurt, emphasised its significance for the Germany's situation in the Second World War, in which the Germans were once again fighting for their future 'with blood and iron'. Krebs noted that Miegel's East Prussian homeland had been united once more with the rest of Germany as a result of German military victories:

She ['Mother Germany'] did not forget the wistful call for help that could be heard coming from this German heartland over the course of many years of separation, the same call for help that found such moving expression in the poem by Agnes Miegel, 'Ueber die Weichsel drüben'. It is, therefore, no coincidence that this year the unanimous choice of the curatorium for the Goethe-Prize fell on the poet Agnes Miegel from Königsberg, for alongside the recognition of her art in the spirit of Goethe it is also a strong recognition of East-Prussian Germanness, which through her work is brought in such a special manner to the consciousness of the whole community of the German Volk, with its single shared fate. ${ }^{106}$

In her response, Miegel thanked Krebs. She noted that the Goethehaus was the house of Goethe's parents and remembered her own. The newspaper used this opportunity to communicate a racial message in line with

IO4 Ibid.

IO5 'Feierstunde im Hirschgraben' (Frankfurter?) General Anzeiger, 28.08.1940, DLA - A: Miegel, 3: Zum Leben und Werk.

Io6 From the speech delivered by Oberbürgermeister Stadtrat Dr. Krebs of Frankfurt am Main at the award ceremony to present Agnes Miegel with the Goethepreis der Stadt Frankfurt, reproduced in 'Feierstunde im Hirschgraben'. 
Nazi ideology, noting that nothing could have given more straightforward or more honest expression to eternal ancestry. ${ }^{107}$ The Stuttgarter Neues Tagblatt also reported on Miegel's award in its women's pages, presenting a slightly different angle, but nonetheless remaining within the boundaries of propaganda. The article describes the simplicity of Miegel's life, rooted in Königsberg. It was this place and the surrounding landscape that had formed Miegel's work. Combined with her love of the classical world, the foundation of German culture, and her mastery of form, Miegel was a suitable successor to those who had been awarded the prize before her; what bound her to Goethe was the way in which 'the smallest detail taken from everyday life can become the most complete portrait of the cosmos in her poetry, an eternal song of fate and the beauty of the whole world, of the sated fullness of existence. ${ }^{108}$

Kolbenheyer was the recipient of the largest number of prizes of any writer during the Third Reich, receiving accolades at various levels from local to national. In 1933 he was awarded the Literaturpreis des Goethebundes Bremen, which, according to Helga Strallhofer-Mittermeier, was probably the only occasion on which it was awarded. ${ }^{109}$ More significant, perhaps, was the award of the Literaturpreis der Stadt München in 1936. First awarded in 1927, this prize counted among its pre-1933 recipients Hans Carossa, Willy Seidel, Josef Magnus-Wehner, Hans Brandenburg and Ruth Schaumann. As far as the Propaganda Ministry was concerned it was counted among the 'reichsweite Kunstpreise'. New regulations drawn up in 1935 decreed that it could only be given to a German-speaking writer of 'Aryan ancestry' for a work of poetry, drama or epic. In addition recipients must have been resident in Munich for at least five years and have demonstrated potential for ongoing literary success. Moreover, the city authorities viewed the ideological standpoint of the recipients to be of 'decisive importance.' ${ }^{110}$

107 Ibid.

Io8 Dr. Ruth Hildebrand, 'Agnes Miegel erhielt den Goethe-Preis', Stuttgarter Neues Tagblatt, 31.08.1940, DLA - Dokumentationsstelle: Agnes Miegel I: Material aus der Zeit vor 1945 .

I09 Strallhofer-Mitterbauer, NS-Literaturpreise, p. 87.

II Ibid., pp. 30; 89-90. 
Thus, the award of this prize, worth RM 2000, by the 'Hauptstadt der Bewegung' to Kolbenheyer was indicative of the regard he enjoyed in the Third Reich as an ideologically as well as culturally significant writer.

The following year, in 1937, he was similarly honoured with the Goethe Prize. According to Emrich, the prize was presented by Stadtrat Dr. Keller on behalf of the City Mayor at a reception on 28th August in the house of Goethe's birth. Keller recognised Kolbenheyer as among the 'best of the German Volk' who had remained true to his German being. Keller added that as a German from the borderlands, in Kolbenheyer's case the Sudetenland, Kolbenheyer's path had been tougher than that of many others. His particular praise for Kolbenheyer's historical novels, common in commentaries on his work at this time, reflects not only their status in these years, but also the fact that of all his works they were probably the most accessible and therefore best-known. For Keller, the heroes of these novels were 'Faustian' figures, 'who at the turning points of history pointed the way towards the future and raised awareness of great changes on the way.' ${ }^{111}$ Thus Kolbenheyer's work reflected the immutable nature of the völkisch character as it confronted historical turning points. The historical nature of völkisch existence was once again evident in the changes brought by the Nazi regime. ${ }^{112}$

Kolbenheyer's post-1945 account of the award differs a little from that given by Emrich. Kolbenheyer noted that at the time the prize was held in high esteem and the list of prize-winners included a colourful range of writers. In selecting the recipient, he suggested, one of the main voices was that of the Regent of the Goethehaus, Prof. Ernst Beutler, who held this position from 1925 to 1960 and, according to Emrich, was a noted opponent of National Socialism. Kolbenheyer's assumption was that Beutler had not personally read his work, but that Kolbenheyer's position was such that he could not be ignored when considering possible laureates. ${ }^{113}$

II $\quad$ Emrich, Die Träger des Goethepreises, p. I47.

II2 Ibid., p. I47.

II3 Kolbenheyer, Sebastian Karst, vol. III, p. 344. 
The evening before the award ceremony, Kolbenheyer was required to present a lecture on Goethe. In Goethes Denkprinzipien und der biologische Naturalismus he chose to discuss Goethe's work in the light of his own philosophy of 'biological naturalism', which asserted the importance of examining the great German writer and his work from the point of view of the 'psychogenetische Entwicklung des Genies', rather than simply using the methods of conventional literary criticism. Kolbenheyer's convoluted biological approach to Goethe served to tie the writer to the German Volk, in which he occupied in Kolbenheyer's view the position of one of those men of genius who marked a turning point in the history of völkisch development. ${ }^{114}$ Kolbenheyer's account claimed that his lecture had not been well received on the occasion in Frankfurt. Distancing himself from the establishment gathered to witness his award (and therefore those granting it), he may nonetheless have been right in suggesting that only the folk songs that were performed following his presentation provided his audience with the entertainment they were hoping for. ${ }^{115}$ All the same, his account reflected his efforts to counter post-war attempts to use the award as evidence of his subservience to the regime. ${ }^{116}$ Continuing his line of argument, Kolbenheyer recollected that the true meaning of the award had been revealed to him only the following day at the award ceremony itself in the house of Goethe's birth. Suddenly, he stated, he was seized by the power of the place itself, and the connection with the generations that had gone before, right back to those who had inhabited the house when Goethe was born. This connection with the German spirit that had breathed through the place in those times was, Kolbenheyer suggested, his personal ceremonial moment. He was therefore also able to turn his account of the event against the Allies who had bombed the city of Frankfurt during the Second World War, destroying the original house in the process. ${ }^{117}$

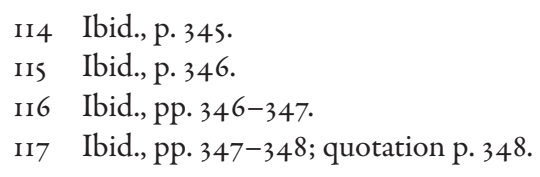


According to Emrich's account, the press responded positively to Kolbenheyer's award and the lecture he gave to accompany it. The Frankfurter Zeitung commented: 'Wenn nunmehr Kolbenheyer eine der bedeutendsten Ehrungen erhält, die einem deutschen Schriftsteller zuteil werden können, wird damit öffentlich anerkannt, welcher Platz im deutschen Schrifttum der Gegenwart seinem Werk zukommt. ${ }^{\text {'118 }}$ The case of Kolbenheyer highlights the drawbacks of Emrich's efforts to address the cultural history of Germany's recent past in the two decades after the fall of the Third Reich. Published in 1963, only a year after Kolbenheyer's death, Emrich's book offers an account of the award through each of its recipients between 1927 and 196I. It is another example of the challenges experienced by cultural commentators in trying to find a way to relate the history of the Nazi years in such a way that the errors of this period were acknowledged without ascribing direct blame to the German people as a whole, or the subjects of commentary in particular, many of whom remained active in German cultural life in the post-war years. ${ }^{119}$

During the Second World War, Kolbenheyer was honoured several times, not least with the Paracelsus Prize of the city of Villach in 1942. Kolbenheyer was judged to be a fitting inaugural laureate for this award largely as a consequence of his Paracelsus-Trilogie. When the decision was made, the Gauleiter of the Kärnten region in Austria, Friedrich Rainer, doubled the prize-money, which Kolbenheyer donated to the victims of the bombing raids on Munich. Two years later Rainer further hoped to increase Kolbenheyer's links with the region by offering him the honorary direction of the newly created Paracelsus-Institute in Villach, which was established in 1944 as an institute of the Faculty of Medicine at the University of Vienna. ${ }^{120}$ As far as it is possible to tell, given the late stage in the War, Kolbenheyer did not accept this offer, and it may have been this position that he later referred to in his defence against post-war accusations that he had supported the regime, when he declared that he had rejected the

II8 Quoted in Emrich, Die Träger des Goethepreises, p. I49.

II) Ibid., p. Io9.

I20 Strallhofer-Mitterbauer, NS-Literaturpreise, pp. 68-7I. 
offer of a university professorship under the Nazis. ${ }^{121}$ In 1944, Kolbenheyer was also awarded the Grillparzer Prize of the City of Vienna. ${ }^{122}$

It was not only as a recipient of prizes that Kolbenheyer was tied into the literary establishment of the Third Reich. In 194I, for example, he was also named an honorary member of the Viennese Academy, and in 1944 a new prize bearing his name was established in his hometown of Karlsbad. The Kolbenheyer-Prize was awarded only once, to Robert Kampe. ${ }^{123}$ In addition, Kolbenheyer was also a member of the jury for the Eichendorff Prize, awarded by Toepfer's Johann-Wolfgang von Goethe Stiftung to representatives of the 'Deutsche Volkstum in der Tsechoslowakei' between I936 and 1944. In 1937 his fellow jurors included Herbert Cysarz and Otto Grosser, both from the University of Prague, Hanns Johst representing the RSK and Adolf Meschendörfer for the Auslands-Institut. ${ }^{124}$ Similarly, Hans Grimm sat on the jury for the Volksdeutscher Schrifttumspreis der Stadt der Auslandsdeutschen, Stuttgart when it met in May 1938. His fellows included Karl Strölin, the Lord Mayor of Stuttgart, Blunck in his capacity as former President of the RSK, Richard Csaki, director of the Deutschen Auslands-Institut in Stuttgart, Johst as President of the RSK, Gerhard Schumann, Reichskultursenator and a native of Stuttgart, and the writer Erwin Wittstock from Hermannstadt to represent Auslandsdeutsche themselves. ${ }^{125}$ While, as Strallhofer-Mittermeier points out, juries frequently only had an advisory role as far as prizes were concerned, and therefore did not have the privilege of deciding on the recipients, they remained another way in which individuals could represent the regime in cultural affairs. The inclusion of Hans Grimm is particularly notable given that he was not awarded a single prize during the regime. This has been put down as a

I2I Kolbenheyer to Grimm, 27.II.I947, DLA - A: Grimm, Kolbenheyer to Grimm, 1946-1959.

I22 Strallhofer-Mitterbauer, NS-Literaturpreise, p. 53; Strallhofer-Mitterbauer points out that in Literatur unterm Hakenkreuz, p. 503, Loewy mistakenly listed the year of Kolbenheyer's award as 1943.

I23 Strallhofer-Mitterbauer, NS-Literaturpreise, pp. 107-108.

I24 Ibid., p. 46.

I25 Ibid., pp. 106-107. 
sign of Grimm's unpopularity with leading figures in the government, not least by Grimm himself; it is, however, more likely that it can be explained by the fact that he published little that was new in these years, and the works he did produce tended to be of a political nature, precursors to his post-1945 publications, rather than fiction.

In practice several drawbacks emerged regarding prizes in the Third Reich. Not least of these was the devaluation of the prestige attached to literary prizes in Germany, resulting both from the lack of 'National Socialist' authors to receive them, and from the large number of prizes at every level. In December 1937, Schrifttumsreferent Erckmann in the RMVP summarised the negative effects of the uncontrolled development of the literature prizes in a report for Goebbels. Conducting research with the regional offices of the Propaganda Ministry, Erckmann found that in the whole of the Third Reich about 70 literary prizes were being awarded. ${ }^{126}$ As this quantity bore no relation to the quality of writing being produced in Germany, many writers were the recipients of numerous awards and some new writers were being awarded prizes on the basis of only their first work. Erckmann concluded that the result was a devaluation of the literature prizes in the perception of the public. He therefore proposed a fundamental reform of the prize system. While reducing the prizes was not advisable economically, he recommended that a number of prizes should be turned into scholarships and one-off sums to assist writers. Goebbels reacted positively to his suggestion and on 26 th January 1939 ruled that the award of prizes of more than 2,000 RM could only occur with his permission. The directors of the regional propaganda offices were to be members of the selection committees and a shortlist of candidates for each award was to be submitted to the Propaganda Ministry for its approval at least four weeks before the award ceremony. ${ }^{127}$

The administration of the prizes also created problems of coordination. A letter from the J. Engelhorns Nachfolger/Adolf Spemann Verlag

I26 For lists of prizes, see B.Arch.R56V-9I.

I27 Undated memorandum in RSK, I936: 'Betr. Ständige Literaturpreise', B.Arch.R56V9I; Barbian, Literaturpolitik, pp. 464-469. 
of Ist September 1942, addressed to the Propaganda Ministry and copied to the President of the RSK, highlights both the problems and also the desired achievements of literary prizes. The publisher was responsible for the publication of the work Carl von Bremen by Wilhelm Hymmen, which won the Hermann-Löns-Prize of that year, named in honour of the Heimat author of Der Webrwolf who was killed in the First World War. In this case the publisher complained that he was not given sufficient notification of the award and was therefore unable to make preparations for the increased demand it created: '[...] the point of such an honour is also to lead to a greater dissemination of the prizewinning books. The consequence therefore is almost always an increased demand. How, however, should the publisher meet this when he isn't informed beforehand!' ${ }^{128}$ While prizes had an effect on the demand for particular works, bad administration could, it seems, sabotage their potential value to the government. In spite of the problems associated with the literature prizes, however, they were nonetheless still felt to be important during the Second World War. In I939 Johst made the decision to continue them into the war years as part of the RSK's war effort. At his request, Goebbels therefore wrote to private benefactors like Toepfer to encourage them to continue their patronage of prizes, which, on the whole, they did. ${ }^{129}$

\section{Völkisch Writers and the Nazi Policy on Literature}

Nazi policies towards literature never went beyond the development stage. When the Second World War broke out the institutions concerned with literature were still defining their roles. Even as late as 1945 the policies of the Nazi Party had still not been fully implemented, the wartime paper

I28 J. Engelhorns Nachf.-Adolf Spemann Verlag to RMVP and the President of the RSK, I.9.1942, B.Arch.R56V-91.

I29 Haegert (RMVP) to Johst, 20.12.1939, B.Arch.R56V-91. 
shortage having limited literary output. There was, moreover, never a cohesive Literaturpolitik in Nazi Germany. While it was agreed that Gleichschaltung should include the literary sphere, the concept was never clearly defined and was therefore subject to individual and often conflicting interpretations. ${ }^{130}$ As a result, there never emerged a literary corpus that could be described as 'National Socialist'. Instead the Nazis adopted those trends in German culture that were compatible with their ideology, and attempted to stamp out any that were not. ${ }^{131}$ A comprehensive, smoothrunning institutional machinery putting into practice well thought-out and cohesive policies did not exist in the Nazi regime. This was partly the result of the sheer size of the bureaucracy involved in executing legislation, but also partly due to the personal rivalries and conflicting interests that characterised all levels of Nazi Literaturpolitik.

The divisions that reigned in the cultural world of the Third Reich should not, however, be reasons to ignore the concrete elements that stood behind the politics of literature. The prejudices that ruled Nazi attitudes did form a basis for the actions of the leading Nazis in the literary world. Anti-Semitism governed the 'Aryanisation' of Jewish publishing houses. In a similar vein, writers who represented the liberal and democratic traditions of the Weimar Republic were ostracised and prevented from publishing their works. These actions served a practical goal in support of the Nazi regime, limiting oppositional voices. They also sought to ensure that the reading material enjoyed by the German population was in line with Nazi principles. It was, however, easier for the Nazis to remove the literature judged to be foreign to the Volksgemeinschaft than it was for them to put a National Socialist canon in its place. As the 'golden' lists issued for the rebuilding of library collections show, their failure to do so left them reliant on the works of völkisch-nationalist writers.

The diversity of the representatives of völkisch thought makes it unwise to generalise about their relationship with the Nazi Party. A number of

I30 Barbian, Literaturpolitik, p. 836.

I3I G.L. Mosse, The Culture of Western Europe: The Nineteenth and Twentieth Centuries; an Introduction (London: John Murray, 1963), p. 371. 
commentators, and not only those on the extreme right with first-hand experience of Nazi literary life, have observed that this relationship was more complex than those seeking in völkisch activity the roots of National Socialism may have suggested. ${ }^{132}$ Two things are worth noting: first, to understand the writers that are the subject of this book it is necessary to differentiate between their ideological similarities with the Nazis and their personal attitudes towards the NSDAP. The latter were frequently based on their elitist social instincts. So, for example, Hans Grimm found the mass politics of National Socialism distasteful, warning against allowing the 'movement' to become part of the class struggle that was the basis of the Marxist workers' organisations. At the same time, he expressed sympathy for the racial ideology that underpinned the NSDAP, seeing in it an expression of the 'German' cause for which he also stood. ${ }^{133}$

Second, a number of the writers in question reinterpreted their relationship with the Nazi regime after 1945. Unsurprisingly, these accounts tend to highlight the differences rather than the similarities between the two. The task of negotiating a path between the different perspectives on the German right after 1933 is complicated by post-war sensitivity to the negative consequences of association with Nazism, as well as the political agendas at work after 1945. Grimm and Kolbenheyer did not simply seek to clear their own names after the Second World War; their post-war commentaries were written with a political purpose, namely the application of their völkisch worldviews in opposition to both Bolshevism and the new Federal Republic of Germany (FRG). The view of the Nazi Party and regime that they presented was coloured by their opposition to the systems that followed its downfall.

After 1945, völkisch writers' efforts to combat association with the Nazi regime led them into confrontation with literary colleagues, journalists and other commentators in public life, particularly those returning from exile or incarceration, who viewed them as the literary representatives of

I32 Puschner et al., 'Introduction' to Handbuch, pp. IX-X.

I33 See, for example, the discussion of the 'Bitte an den Nationalsozialismus', published by Grimm and Winnig in 1932, on pp. 87-92. 
the regime. And indeed, in many ways that is what they became between 1933 and 1945 . But they were not products of National Socialism and they did not necessarily understand themselves as 'Nazi' writers. There is a danger that the automatic association of völkisch writers with National Socialism leads to an over-simplified understanding of cultural life in the Third Reich. While the Nazis certainly waged a crusade against writers whom they identified as politically unacceptable or racially foreign, those left behind continued to represent a spectrum of views and responded to the regime in a variety of ways. The differences in the perspectives of the individual writers considered here and the ongoing fluidity in relationships across the cultural sphere more generally after 1933 , albeit within an altered, narrower ideological framework, also suggest the possibility of a nuanced spectrum of 'acquiescent' attitudes towards the regime among the population at large.

From the perspective of the Nazis, there was also some ambivalence towards the völkisch movement. Hitler's declared attitude was critical rather than enthusiastic. Victor Klemperer noted in his examination of the language of the Third Reich that Hitler viewed the Völkischen as competition, rejecting their 'folksy' aspects, whilst seeking to instrumentalise some of their goals to benefit the National Socialist cause. ${ }^{134}$ Nonetheless, rhetorical rejection of völkisch thought does not negate the fact that the Nazis were also representatives of a völkisch worldview. Indeed, their concern was to draw leading writers like Grimm and Kolbenheyer into their own ranks. The tensions that emerged between Party representatives and several völkisch writers after 1933 resulted because the continued independence of the latter presented a challenge to the monopoly over racial nationalism the Nazis sought to establish; they did not represent fundamental ideological differences, but a struggle for intellectual control.

Given Hans Grimm's popularity with Goebbels in the early I930s, it was unsurprising that he was appointed to the board of the RSK following the Nazi Machtergreifung and the foundation of the RKK in 1933. Barbian suggests this was partly intended in recognition of his services to nationalist

I34 Puschner et al., Handbuch, pp. ix-x. 
literature and National Socialism, and partly as a way of harnessing his reputation to the RSK. ${ }^{135}$ By 1942 Volk obne Raum achieved total publication of 540,000 copies, the title providing the Nazis with a slogan for territorial expansion, albeit in Eastern Europe rather than Africa. At most, in the long term Africa might provide raw materials for the regime; it was not an area marked out for settlement. Grimm's position regarding the policies of the regime was therefore ambiguous from the outset, even if many of his fundamental principles corresponded to Nazi thinking. ${ }^{136}$

Grimm does not appear to have understood the concerns of the propagandist. His efforts to provide support for the Nazi Party, particularly through election endorsements in the early 1930 s were based on the idea that he would offer original and independent thoughts on the German situation and the Nazi contribution to it. In the course of time, Grimm proved an increasingly outspoken critic of the RSK, and the government. He believed his position on the board of the RSK obliged him to provide constructive criticism. Selected as a result of his proven literary achievements, Grimm assumed that he had been called to be a commentator on the progress of the new regime in the literary sphere. And to a significant degree he did become the mouthpiece of his völkisch-nationalist colleagues with the government in the early years of the Third Reich. On 23rd April 1935 he wrote to Blunck:

The men named above [Jünger, Kolbenheyer and von Salomon], and with them certainly nine tenths of all national writers of name, believe that as a member of the board of the chamber I have the opportunity and the duty to bring up things for discussion, which quite unnecessarily damage German cultural prestige, and as a consequence must also cause increasing political damage to the state. ${ }^{137}$

Grimm's understanding of the purpose of the RSK and its constituent institutions did not mirror that of Goebbels and the Nazi leaders. While the latter

Ibid. p. 404 .

I36 See Schoeps, Literatur im Dritten Reich, pp. 73-74, 78-79; Peter Zimmermann: 'Kampf um den Lebensraum: Ein Mythos der Kolonial- und Blut-und-Boden-Literatur', in Denkler and Prümm (eds), Die deutsche Literatur im Dritten Reich., p. 170.

Grimm to Blunck, 23.4.1935, B.Arch.R56V-187. 
were primarily concerned with questions of censorship, propaganda and control, Grimm took a more idealistic völkisch view of literary institutions, seeing their role as one of social and political representation of a clearly defined literary estate, or Standesvertretung. The organisation of German society according to estates was viewed by völkisch-nationalists as the basis for its healthy development in the future. Grimm adopted the idea as the basis for the formation of political institutions that would represent writers, and other professions in book production and the book trade, as their own social estates. Such representation would be concerned both with the wellbeing of writers and also the quality of the literature they produced.

Early on Grimm identified the lack of definition between the various organisations in the literary sphere during the Third Reich as the greatest impediment to achieving the goals of völkisch-nationalist writers in Germany. He did not hesitate to point out the problems he perceived to senior Nazis. On 24th April 1935, he let Goebbels know that 'If things continue as they are, the estate will be increasingly gambled away, art will be hindered and the cultural reputation of the Third Reich pointlessly endangered. ${ }^{138} \mathrm{He}$ also reiterated opinions already made clear to Blunck in a letter of 23 rd April 1935 at a meeting of the board of the RSK on 5 th June I935, comparing the RSK's provision for the needs of booksellers with that for writers and concluding that the needs of the former were better met. He emphasised that writers, just as booksellers, should be recognised as a separate 'estate' and controversially suggested the Reichskammergesetz itself was the root of the problem, having resulted in a bureaucracy to control writers instead of a framework in which serious writers could exist as a social estate. He thereby directly criticised Nazi lawmaking. Grimm's contribution to the meeting demonstrated his elitist attitudes. He suggested that 'real' writers should be separated from the masses, who simply earned a living with the pen, through the formation of an elite organisation. The members

I38 Grimm to Goebbels, 24.4.1935, DLA - A: Grimm, Grimm / Regierungs- und Parteistellen - Briefe von ihm an Deutschland, Deutsches Reich, Reichsministerium für Volksaufklärung und Propaganda, 193I-1939; also quoted by Barbian, Literaturpolitik, p. 405 . 
of the proposed organisation should, moreover, be allowed to decide for themselves who would join their ranks. Journalists and essayists were to be firmly excluded. ${ }^{139}$

Grimm also made himself unpopular with his criticisms of the way in which the Reichsverband der deutschen Schriftsteller (RDS) developed. Formed in June 1933 out of several previously existing organisations, the RDS was charged, among other things, with the establishment of a catalogue of names and addresses of all writers active in Germany, alongside an archive of newspaper clippings and other information on literary activities. It was therefore utilised by the government less as an instrument to support German writers, but rather to watch over and control them. ${ }^{140}$ With the passing of the RKK-Gesetz on Ist November 1933, the RDS in turn became the RSK, although a sub-organisation named the RDS remained present within the RSK.$^{141}$ Its badly defined purpose provides yet another example of the institutional confusion that reigned in the literary world during the Third Reich. ${ }^{142}$

Grimm's criticisms of the RDS differed little from his complaints about the RSK. On a superficial level, he objected to the inefficient and over-bureaucratic nature of the organisation. ${ }^{143}$ In the RDS, he argued, the men and women of German literature had been presented with a compulsory organisation run by bureaucrats wholly uninvolved in the creation of German literature. He further observed:

The office publishes a journal in very bad German, which is sent to us. The office has made a fantastic suggestion that the bad journal should be expanded without remuneration in order to compete with serious journals! [...] The office has attempted

I39 Speech by Grimm at a Sitzung der RSK, 5.6.1935, B.Arch.R56V-I87; see also Grimm to Blunck, 23.4.1935, B.Arch.R56V-187.

I40 See report of an examination of the RDS by Arnold Stehlik, commissioned by the Geschäftsfübrer of the RSK and carried out between 29.3.1935-3.4.1935 and 17.4.1935-2.5.1935, B.Arch.R56V-73, p. I .

I4I 'Protokoll der Sitzung des Führerrats des Reichsverbandes Deutscher Schriftsteller e.V.' on 20.9.1935, B.Arch.R56V-73, pp. 4-5.

I42 Barbian, Literaturpolitik, pp. 837-838.

I 43 Ibid. p. 404 . 
to interfere in the affairs of our publishing houses and our royalties without any knowledge at all of these concerns. The office has recently tried to establish a pointless correspondence with the press. The office has, as it announced in print, recently decreed a - as far as I can see legally completely untenable - tax intention, according to which those of us true professionals are expected to contribute very substantial contributions from our gross income, doubtless above all to cover the expenses of the enterprises of the office; to put it mildly, whatever happens to this money, we members who provide it will not benefit. We writers will not gain any material, let alone ideological profit from the office. We only publicly share the responsibility for the ignorance of a central office, which $[. .$.$] is no longer even a subject of jokes. { }^{144}$

To solve the problem, Grimm suggested that the RDS should continue to exist as the first collection point for those who wrote for a living, and in so doing could continue to bureaucratise literary endeavour. In addition Grimm proposed the establishment of a separate organisation for 'Dichter', which would free its members from the obligation of membership in the RDS. Grimm was therefore concerned with gaining greater freedom for 'Dichter', as opposed to 'Schriftsteller', from the controls of the Third Reich.

Grimm's criticisms, though received coldly by the Nazi leadership, did not fall on deaf ears. Secretary of State Funk noted in the margins of one of Grimm's epistles: 'The deficiencies of the chambers and the assemblies are evident all over the place!' ${ }^{145}$ The Nazis were aware of the problems of the RDS, its inefficiency and its lack of definition. ${ }^{146}$ In addition, with its formation the RDS took on the not inconsiderable debts of its predecessor organisations, the burden of which fell on the writers who were forced to contribute to it. These problems rendered it functionally impotent in the Third Reich and were among the reasons for its eventual abolition, announced on 30 th September 1935 and carried out over the following twelve months. Its assets and members were directly transferred to the RSK, which itself underwent a streamlining process, in the course of which the identifiable competencies of the RDS were subsumed into what became the Gruppe Schriftsteller

I44 Grimm to Blunck, 23.4.1935, B.Arch.R56V-I87.

I45 Quoted in Barbian, Literaturpolitik, p. 405.

I46 See Stehlik's report, B.Arch.R56V-73. 
in autumn $1936 .{ }^{147}$ The fate of the RDS reflected the tendency of the Nazi government, particularly in the areas that Goebbels controlled, to allow controversial organisations to become marginalised. Its dissolution was due to its complicated financial situation. Hans Grimm emerged from the controversy over the RDS with a reputation as a trouble maker who refused to toe the line. On the occasion of his 6oth birthday in March 1935 he was dismissed from the board of the RSK, the formal reason given being his age. ${ }^{148}$

Blunck too was replaced by Johst as President of the RSK in 1935, due both to his lenient attitude towards Jewish writers who had served in the First World War, and to the fact that he was not a member of the NSDAP. ${ }^{149}$ Further changes in the Präsidalrat also took place in the years that followed. ${ }^{150}$ By January 1939 it consisted of ten men, including Hugo Bruckmann, the publisher of Houston Stewart Chamberlain's works and a long-time supporter of the Nazis. ${ }^{151}$ Likewise the list of members of the

I47 'Protokoll der Sitzung des Führerrats des Reichsverbandes Deutscher Schriftsteller e.V.' of 20.9.1935, B.Arch.R56V-73, p. I. See also: Letter from RSK to Finanzamt Charlottenburg-Ost, 5.I.1937, B.Arch.R56V-73; Barbian, Literaturpolitik, pp. 207-2I2.

I48 Grimm to Binding, 23.3.1935, DLA: Nachlaß Grimm, Grimm to Binding, I935.

I49 Barbian, Literaturpolitik, p. 405. See below, p. I75. Blunck's removal from the position of President of the RSK is also commented on by Glenn Cuomo, 'Hanns Johst und die Reichsschrifttumskammer: Ihr Einfluß auf die Situation des Schriftstellers im Dritten Reich' in Jörg Thuneke (ed.), Leid der Worte., p. II2. Cuomo relies too heavily, however, on Blunck's own account of the situation, in which he suggested that he protested against strengthened censorship, and more importantly against a renewed effort to exclude Jews from the RSK in 1935. See: Hans Friedrich Blunck, Unwegsame Zeiten: Lebensbericht, vol. 2 (Mannheim: Kessler, 1952), pp. 313-314. While his correspondence with Hans Grimm suggests that Blunck did indeed take a milder view of Jewish membership than Johst, Blunck's account is unreliable, not least because it was first published in 1952, at a time when Blunck was trying (successfully) to revive his career.

I50 See for example: Fröhlich (ed.), Die Tagebücher von Joseph Goebbels, 25.II.1937, part I, vol. 3, p. 343; 4.I2.1937, p. 355 .

I5I List of members and structures of the RSK, ca. January 1939, B.Arch. R56V-48: The ten men were: Staatsrat Hanns Johst, Gerhard Schumann, Martin Wülfing, Dr. Hans Friedrich Blunck, Karl Baur, Wilhelm Baur, Bürgermeister Krogmann, Theodor Fritsch, Hugo Bruckmann, Karl Heinz Hederich. 
Reichskultursenat in the same year also included several prominent völkisch names, including Bruckmann and Emil Strauß. ${ }^{152}$

Hans Grimm's position in the Third Reich was made more difficult by his inability to understand the limitations to his influence, particularly from the mid-I930s onwards. The cultural context changed under the new rulers. Grimm's ongoing assertion that he should remain a sympathetic but critical commentator, outside the Party structures, was less enthusiastically received by Goebbels once he was Minister for Propaganda than it had been when public engagement with Grimm had the advantage of lending intellectual respectability to the NSDAP at a time when the Party was closely associated with outbursts of street violence in cities like Berlin. Once the NSDAP was in power, Grimm was expected to subordinate himself to the regime; his failure to do so led to problems that will be introduced here and discussed in more depth in subsequent chapters.

Grimm's problems began in 1934 when he voted against the amalgamation of the offices of Reichspräsident and Reichskanzler in the referendum staged by the Nazis in August of that year. Writing after 1945, Grimm noted that already on the day of President Hindenburg's death, Hitler called for the referendum. According to Grimm's account this was to take place in line with the free and secret ballot outlined in the Weimar constitution, which was still officially in force. The igth August was selected as the day on which the vote would be held. In early August Grimm received a request from both the Reichsrundfunk and the Propaganda Ministry asking him to contribute to the election campaign with two public statements on the radio endorsing the plan. He immediately responded by saying that he was unable to do so as he was not in favour of the proposition. As an explanation he suggested that Hitler's presidency, which appeared to have the support of a large majority of the population, would only be useful under conditions that preserved the separate position and prestige of the Chancellor. Grimm felt that this was important both for Germany's standing abroad and because the national revolution was not yet completed. In all revolutions,

I52 List of members and structures of the RSK, ca. January 1939, B.Arch.R56V-48. 
he argued, a certain amount of 'dirt' would be stirred up. The role of the Chancellor, therefore, was to catch the bullets, if necessary taking responsibility by resigning or accepting dismissal. Thus, the President - here Grimm appears to assume that this office would be occupied by Hitler - would remain untouched by the 'dirt'. At the same time, Grimm informed the Propaganda Minister that he intended to vote 'No' on this question. In his post-war account, he added that in the two weeks that followed his letter, a campaign was pursued against possible 'No' votes. Grimm declared that his intentions had been known only to Goebbels and in two other offices in Berlin. On his way to the ballot, he recalled, he had met his son, who appeared downcast on returning from casting his own vote. Wernt Grimm reported that he had intended to vote in favour, but noted that the ballot paper carried indentifying marks. As a result he decided to vote against the proposition, as his father also went on to do. Grimm declared that when he arrived at the polling station he had noted nothing untoward with the ballot paper himself; nonetheless, the same evening, the names of those who had voted against the action were known in Lippoldsberg.

For Grimm, the way in which the regime manifested itself at a local level was important. He described a visit to the Nazi Ortsgruppenleiter the following day to find out what had gone on. He pointed out, he said, that breaching electoral secrecy was punishable with prison. The official denied all involvement. Grimm appears to have believed him; his postwar description of him as a decent man who, whilst still a young socialdemocratic factory worker, had served in the First World War, before discovering National Socialism as a member of the Freikorps fighting in the Baltic states and Silesia, is noticeably reminiscent of Cornelius Friebott, Grimm's hero in Volk ohne Raum. Conveniently, in Grimm's account, the Ortsgruppenleiter's views appear to have overlapped with Grimm's own; thus he prevented the public display of Der Stürmer in the village and ordered the slogan 'Die Juden sind unser Unglück' to be removed from the noticeboards constructed for this purpose. ${ }^{153}$ 
As a result of the inconclusive nature of his meeting with the local Nazi official, Grimm wrote to Wilhelm Frick, responsible for electoral procedures as Reich Interior Minister, and in whose name, Grimm pointed out, the free and secret ballot had been guaranteed. Unlike Grimm's post-war account, this letter suggests that the Ortsgruppenleiter appeared to know who had been responsible for the electoral irregularities and intended to present his own report on the matter. Grimm also outlined again his reasons for rejecting the proposition put forward in the referendum, before going on to emphasise the broader significance of such local instances, highlighting his concern about the direction in which Germany was going. Grimm's concern, as he expressed it to Frick, was to ensure that the Party and the German revolution remained clean and untainted by corruption, thereby also preserving the faith of the German people. ${ }^{154}$ Grimm noted in his account of these events in Warum - Woher - Aber Wobin? that, while he knew Minister Frick to have been a man of honour, he did not receive a response to his letter. Neither was any action taken with regard to the question of the election. When it was clear that nothing was going to happen, he informed the Ortsgruppenleiter and the local group of the NSDAP that he would not participate in further electoral procedures until things had been set straight. He remained true to this intention, with three exceptions: he voted in favour of rearmament, the return of the Saar region to Germany, and the Anschluß with Austria, his mother's homeland. Years later, Grimm reported after the Second World War, he learned that his letter of August 1934 and two further letters directed at Frick in 1936 had not reached the Minister. Instead, as became apparent in an uncomfortable meeting with Goebbels in 1938 , discussed further in Chapter 4 , they were passed on by an unknown official to be copied and kept on file for use against him should the occasion arise. ${ }^{155}$

The two letters sent to Frick in 1936 also dealt with a referendum process. On 28th March 1936, he raised his concerns regarding the way

I54 Hans Grimm to Wilhelm Frick, 25.9.1934, DLA, A: Grimm, Grimm to Frick, 1934-1936.

I55 Grimm, Warum - Woher - Aber Wohin?, pp. 175-177. 
in which the question for the referendum held on foreign policy issues had been phrased. As Grimm later explained, as a consequence of the French-Russian Pact ratified in February 1936, the German population was asked to give its support to the government's foreign policy, particularly its handling of the re-militarisation of the Rhineland and the abandoning of the Locarno Treaty. At the same time, however, the public was required to give its approval for the methods used by the Party domestically; it was not possible, and this was Grimm's initial complaint, to vote in favour of the former without saying 'yes' to the latter as well. In his post-war commentary, Grimm presented a quotation from his letter, writing:

I stated: 'I can only say yes, when it comes to opposing the Versailles Dictate. With this yes, I may hoewever mislead men like you, Herr Minister. I therefore point out that my yes, alongside the yes of millions of other silent Germans, is not a declaration of trust in the methods of the Party over the last three years ... I would go as far as to say, Herr Minister, that the Volksgenosse is more hurt today by false propaganda, by innumerable individual negative instances and fear for job and bread than he was three years ago. Herr Minister, I desire the realisation of National Socialism. Herr Minister, help stop the destruction of the state and the incurable fragmentation of Germany due to a misapprehended Party ... Please help to make sure that the Führersystem does not become a system of Führer, who end up destroying the Führer.' ${ }^{\text {,15 }}$

It is worth noting that while this version more or less mirrors the content and style of the original letter in Grimm's papers, it is a selective quotation that includes some minor inaccuracies. Nonetheless, while differences are evident, overall it would seem that Grimm's post-war representation of his 1936 position on this matter was quite accurate. It is also possible, as his handwritten corrections on the copy of the letter indicate, that there were minor differences between the version kept in his records and the one that finally made its way to the Interior Ministry.

The second letter of 1936 , sent on 4th April, dealt with the same referendum. Grimm noted in his later account that the only 'No' vote in Lippoldsberg was cast by a 42 -year-old worker, Friedrich Remhof. By now there was little pretence with regard to electoral secrecy. According 
to Grimm, Remhof sought to avoid voting altogether, but was forced to the ballot and therefore decided to vote against the motion. A local Obersturmführer in the SS, whose apparent Nazi enthusiasm, Grimm stated, had already done the reputation of the movement some damage, decided to act as judge and avenger. He pursued the unfortunate Remhof, bringing him before an ad hoc court before setting his comrades on him during the night, mishandling him severely. On hearing of these events the following morning, Grimm took it upon himself to visit the Public Prosecutor's office in Kassel and persuaded him to press charges against the Obersturmführer for inflicting grievous bodily harm. He also informed the Minister of the Interior of the case in his letter of 4 th April. ${ }^{157}$ In this case, the original version of the letter is more strongly critical than Grimm's post-war account: Grimm described for Frick's benefit and in considerable detail the ordeal of his fellow villager. ${ }^{158}$ The role Grimm appears to have adopted in this instance fits with that more generally seen in his relationship with the village and tells us a lot about the way in which he understood his own position in society: Grimm appears in these accounts as the village squire or aristocrat. He seems to have had a patriarchal sense of responsibility for his community, using his contacts and position on its behalf, but in a distant, moral spirit of one who exists in and with the community, but considers himself socially above those around him. He therefore added a paragraph towards the end of this letter to Frick that said: 'Herr Minister, I have made the name of this village known and admired through the world. I want to rescue what can be rescued. I am the only one here who can still take this risk, I know that I put myself in danger in doing so. ${ }^{159}$

In his post-1945 report, Grimm noted that this letter too went unanswered. From the public prosecutor's office in Kassel he eventually received notification that the case had fallen under an amnesty and would therefore not be taken any further. Rudolf Hess, known to Grimm as a result of their correspondence regarding the 'Bitte an den Nationalsozialismus' in 1932 ,

157 Ibid., p. 178 .

I58 Grimm to Frick, 4.4.1936, DLA, A: Grimm, Grimm to Frick, 1934-1936.

I59 Ibid. 
did take the matter up with the Party leadership. In spite of this, Grimm noted, the perpetrator of the violence in Lippoldsberg was only expelled from the SS several months later and after much prodding by Joachim von Ribbentrop. While the outcome was unsatisfactory from Grimm's point of view, this instance suggests that, whatever difficulties he may have had in the Third Reich, he also benefited from the ongoing functioning of established networks. ${ }^{160}$ The character of these networks will be examined further in the chapters that follow.

I60 Grimm's papers do not contain any correspondence with Rudolf Hess on this matter. It is possible, however, that Grimm spoke to Hess personally during one of his visits to Berlin. The same may be true for Ribbentrop, although it should be noted that the latter was German Ambassador in London at this time, which would have made a personal meeting more difficult. Nonetheless, Grimm may possibly have discussed the case with Ribbentrop during one of his lecture tours in Great Britain. 


\section{The German Literature Academy: Control Mechanism or Cauldron of Dissent?}

In the early years of the Third Reich, völkisch-nationalist networks took on a new character. As many prominent writers went into exile or were excluded from Germany's literary institutions because of their race or political views, the Nazis required the support of well-known nationalists to replace them and provide the new regime with literary representation. This was important for Germany's image both domestically and abroad, and ensured these writers recognition as the nation's literary elite.

In contrast to the Weimar Republic, against which völkisch-nationalist writers stood in clear opposition, the establishment of the Third Reich presented them with a völkisch state. It did not, however, represent the ultimate achievement of their goals. Instead, they viewed the Machtergreifung as a significant step in the ongoing progress of the völkisch revolution. Many greeted the Nazi regime enthusiastically as an opportunity to take control of the cultural leadership of the nation. They saw it as a chance to revive the true creativity of the Volk after an era of degenerate, liberal modernism in the arts. The Nazis' own revolutionary rhetoric did little to discourage this view in 1933 , and many adherents to völkisch-nationalism only acknowledged several years later that in reality they were powerless to create a völkisch state in accordance with their ideals; instead, they were harnessed by the Nazis to serve the regime's propaganda needs.

This situation was clearly illustrated in the German Literature Academy, which was formed following the Gleichschaltung of the Literature Section of the Prussian Academy of Arts in 1933. Most of its members belonged to the older First World War fighting generation. The presence of Ina Seidel and Agnes Miegel further contributed to the völkisch-nationalist character of the organisation. The new Academy was therefore informed by the common cultural background of its members, who displayed in their writing 
similar reactions to recent historical events. Their correspondence shows that their acquaintance rapidly moved beyond narrow Academy concerns as they sought to forge a place for 'German' literature in the new state.

After 1945 several writers involved in the Academy during the Third Reich referred to their failure to achieve their völkisch vision through this institution as evidence of their differences with the Nazis and their distance from the regime. ${ }^{1}$ Nonetheless, their position was more complex than they later suggested. Their initial sympathy for the Third Reich and their personal ambitions increasingly came into conflict with their elitist view of society and their place in it, making them unwilling to bend without question to the Nazi will. Applying the Führerprinzip, favoured by völkisch-nationalists and Hitler alike, they claimed a right to contribute independently to the regulation of German literature as the self-proclaimed intellectual elite of the völkisch-nationalist state.

In practice, therefore, the Academy produced conflicting results in the Third Reich. On the one hand, it won the regime the initial support of prominent völkisch-nationalist writers by providing them with membership of a historically prestigious institution. It also functioned to protect the Nazis' ideological monopoly by containing independent nationalist voices in a single body in which differences of opinion could be controlled. On the other hand, it provided these writers with a forum in which to meet and discuss their ideas. As several became increasingly frustrated at their inability to achieve their ideal of an Academy above everyday politics, it became a seedbed for nationalist dissent.

\section{The Völkisch-Nationalist Vision for German Literature}

In the third volume of Erwin Guido Kolbenheyer's post-war autobiographical novel Sebastian Karst über sein Leben und seine Zeit, substantial attention is devoted to the author's role in the Third Reich. Published almost a

I Not least Grimm in Worum, - Woher-Aber Wobin?; and Kolbenheyer in Sebastian Karst. 
decade after the denazification process from which he eventually emerged as a Mitläufer, ${ }^{2}$ this work demonstrates how little his perspective was changed by the western allies' post-war efforts to re-educate the German people.

Highlighting Germany's problems in the early 1930s, particularly the Versailles Treaty and the 'short-sighted policies' of politicians at home and abroad, Kolbenheyer suggests that those who were able to see beyond the power games of everyday politics in 1933 were right to view the new regime as the future not just of Germany, but of the whole of 'white Christendom'. For Kolbenheyer as a Sudeten German it had promised to solve his overriding political concern: the unification of the Great German Reich. ${ }^{3}$

Kolbenheyer also emphasised his sense of obligation towards the German people. ${ }^{4}$ During a series of lecture tours in 1933 he had sought to issue a 'public warning' about the dangers facing the German Geist, reminding his audiences of the threat an immoderate emphasis on party politics posed to cultural and particularly literary life. ${ }^{5} \mathrm{He}$ spoke to students and academics across Germany, in addition to members of the general public and on the radio. ${ }^{6}$ At performances of his play Das Gesetz in dir he delivered his lecture 'Die nationale Revolution und das Aufleben des deutschen Geistes'. Here he outlined his vision for the German literary sphere. He compared the events of January 1933 with the Reformation, reasserting the völkisch-nationalist belief in revolution as necessary for the renewal of the German Volk. For Kolbenheyer, it was important that, like the Reformation, the 'German revolution' of 1933 was not inspired by the foreign ideas of freedom that had caused earlier 'freedom movements' to fail. Alien to German culture, the Enlightenment thought that had inspired the I 848 revolutions and the rational materialism of Marxism that inspired the revolutionary events after World War One were closed to the true nature

2 After appealing the initial verdict of Schuldiger: See discussion of Kolbenheyers denazification, pp. 299-304.

3 Kolbenheyer, Sebastian Karst, vol. III., pp. 163-164.

4 Ibid.

$5 \quad$ Ibid., p. 166.

6 Erwin Guido Kolbenheyer, 'Die nationale Revolution und das Aufleben des deutschen Geistes' in E.G. Kolbenheyer, Gesammelte Werke in acht Bänden: Achter Band (Munich: Langen-Müller, pre-1945), pp. 434-447. 
of the Volk. By contrast, the new era was to draw its momentum directly from the German people.

For Kolbenheyer, the nature of the völkisch revolution was particularly important for understanding the role of German literature in society; the eternal values immortalised in true German literature would ensure that the new era was rooted in the Volk. Art and science did not result from general human activity; they were the products of a specific racial background: 'A Paracelsus, a Luther, a Kant, a Rembrandt, a Beethoven, a Goethe remain German in their being and work, even if they have affected the whole of humanity. But one thing remains: They could not and could never be called party German. They were racial Germans, national in the broadest and highest meanings of the word. ${ }^{7}$ Kolbenheyer compared their position not only with the internationalism in art and science that had been propagated during the Enlightenment, but also with the party politics that had led the Nazis to power. ${ }^{8}$ His interpretation of the events leading up to 1933 recognised that the revolution must first establish a political or organisational foothold through party political activity. Following the breakthrough in 1933, however, this revolutionary activity had to move beyond the pragmatic concerns of party politics to the biologically determined life of the Volk, outlined in his earlier philosophical work. ${ }^{9}$

Kolbenheyer, Grimm, and their colleagues in the German Literature Academy were convinced of their position in the ranks of great German cultural figures, past, present and future. In seeking to preserve the 'überindividuelle Gedächtnisse' of the Volk, contrasted by Kolbenheyer with the changeable and transitory nature of Weimar culture, they had a double function in the national revolution. In the pre-revolutionary period, they were responsible for preserving and building up an intellectual and cultural foundation to preserve and maintain the effectiveness of the 'freedom movement'. They were the guardians of German culture and guarantors of Germany's future. Now, in 1933 , following the breakthrough of the 'freedom

7 Ibid., p. 438 .

8 Ibid., p. 435 .

9 Kolbenheyer, Die Baubütte. 
movement', they were responsible for communicating national liberation to the members of the Volk. The goal of the Volksgemeinschaft would only be achieved when the German revolution had been carried into those areas that revealed the innate nature of the Volk, which was manifested in the technical, economic and military spheres, as well as in its academic and artistic resources.

In the early months of the Third Reich, Kolbenheyer still emphasised the ideological similarities he shared with Germany's the new leaders. His efforts nonetheless focused on the völkisch-nationalist vision of a socially, politically and spiritually united community, defined by blood. This eternal and absolute truth transcended everyday political concerns; the Volk was an organic entity possessing a Geist, or soul. Thus, the health of German literature and the arts, which carried the Volksseele from generation to generation, was vital for keeping it healthy. Literature could not afford to be subordinated to political ambition. Predictably this belief was not shared by the leading Nazis, who alternately applied incentives and threats in their attempts to keep the writers in line. The ambiguous relationship that developed as a result between the Academy's völkisch-nationalist members and the government contributed to the failure of the Literature Academy, apparent in the unresolved debates over its place in the framework of the politics of literature in the Third Reich. These were further exacerbated by internal rivalries between leading government officials, not just between Goebbels and Rosenberg, but also Goebbels and Göring, with Rust, as Prussian Minister of Culture, also involved.

After 1945, Kolbenheyer suggested that his views had been a direct response to the Nazis. Nonetheless, assuming that the dates given in his autobiography for the first of his lecture tours are correct - I2th to 3 Ist January 1933 - these activities were initiated before the Nazis came to power. ${ }^{10} \mathrm{He}$ also misleadingly claimed in his autobiography that his first personal contact with National Socialism occurred at the beginning of a lecture tour in May 1933. In fact, Kolbenheyer had contributed to the activities of the KfdK from the late I920s. Nonetheless, when he met 
the new Nazi Prussian Minister of Culture, Bernhard Rust, in Halle in early 1933, he responded hesitantly to the Minister's request for assistance in reforming the Literature Section of the Prussian Academy of Arts for the new regime. According to Kolbenheyer's account, he insisted first that the principles for the reconstituted Academy should be clearly defined. At this, he was asked to present his own suggestions for the shape it should take. ${ }^{11}$

\section{Upholding 'German' Literature in the Weimar Republic}

Kolbenheyer's autobiography was written with the intention of clearing the author of charges of having been a Nazi. At the same time, he sought to present his völkisch-nationalist worldview in a way that made it acceptable in post-war Germany. Nonetheless, his claim that he hesitated to commit himself to the new Academy is probably true given his previous experiences as a member of the Literature Section of the Prussian Academy of Arts during the Weimar Republic. In the eyes of the German right, this organisation was closely bound to the republican regime. Founded on I9th March 1926, it was a battleground between völkisch-nationalist and republican writers from the outset and völkisch-nationalist commentators believed that, more than either of the older sections of the Academy, ${ }^{12}$ it represented liberalism, artistic modernism and republicanism in German culture.

Although völkisch-nationalists cited the Literature Section's Jewish members as evidence of the Jewish domination of German literature before 1933, among its founding members Thomas Mann in particular was determined that it should represent the entire political spectrum in German literature. Following the election of twenty-four writers as members in

II Ibid.

I2 The Prussian Academy of Arts was founded in 1696. In 1926, in addition to the new Literature Section, it consisted of two further sections for fine arts and music. 
November 1926, the völkisch-nationalist right was well represented by Erwin Guido Kolbenheyer, Wilhelm Schäfer, Josef Ponten, Emil Strauß and Hermann Stehr. Inclusion in the prestigious organisation was also recognition that these writers were accepted as serious, established literary figures during the Weimar period and contradicts their own complaints that the Weimar Republic was dominated by liberal, democratic writers. Moreover, there was no counterbalance in the section from the far left. Finally, the majority of members elected in 1926 had made their names before the War, leaving the modernist literature of the I920s likewise under-represented. ${ }^{13}$

In the five years following its foundation, the völkisch-nationalist members of the Literature Section united in their desire to transform it into a German Literature Academy. To this end, in 1927 Kolbenheyer suggested the election of Hans Friedrich Blunck, Paul Ernst, Hans Grimm and Börries von Münch hausen as members. His suggestion was rejected. In 1928, Ponten's nomination of Wilhelm Schäfer as the Section's President, which likewise came to nothing, was predicated on his desire to increase the representation of Landschaft over Großstadt. ${ }^{14}$ By the annual general meeting on 27 th and 28 th October 1929, the divisions in the Section were entrenched. An attempt to address the problems with a proposal to increase membership and thereby the organisation's effectiveness only led to further debate over whether an increase in membership should also involve opening the section to essayists and possibly even journalists. The völkischnationalists opposed the inclusion of professional writers, mere Schriftsteller, into a circle that should be reserved for Dichter. ${ }^{15}$

Broadly speaking, from the völkisch-nationalist point of view, the work of the Schriftsteller was based on intellect and reason, while the Dichter, whom they rated more highly, worked from instinct and feeling, rooted in

I3 Mittenzwei, Der Untergang einer Akademie, pp. 67-68.

I4 Düsterberg, Hanns Johst, pp. 167-168.

I5 An extract of the minutes of the meeting can be found in Inge Jens, Dichter zwischen rechts und links, p. I25. See also Mittenzwei, Der Untergang einer Akademie, pp. II9-I2O. 
his or her identity in the Volk. ${ }^{16}$ This distinction reflected the anti-rationalist opposition of völkisch-nationalism to the legacy of the Enlightenment, which, it was argued, determined modern society. At the meeting in October 1929, this was manifested in a disagreement over the name of the section. While Josef Ponten took the line of the völkisch-nationalists, who emphasised the importance of Dichtung, Thomas Mann proposed changing it from 'Sektion für Dichtkunst' into 'Sektion für Literatur', thereby opening its membership to the widest possible constituency. Kolbenheyer responded to Mann's suggestion on 30 th December 1929 in a letter circulated to all the members. He asserted the Section's existence as the representative of the highest and most profound in German literature: Dichtung. Changing the name of the Section would be a public admission of the weakness of German culture. ${ }^{17}$

The debate gained public attention as a result of energetic efforts by völkisch-nationalists to publicise their position. On the day of the meeting itself, Wilhelm Schäfer expressed his dissatisfaction in the Frankfurter Zeitung und Handelsblatt, adding a further dimension by calling the Literature Section's status as a state institution into question. He argued that while a state could support and protect an academy, it could not direct its activities; the members of an academy, he urged, had a higher responsibility to their art, and as a result the academy had to be autonomous. ${ }^{18}$ This view would re-emerge during the Third Reich among a number of Academy members, including Schäfer, who adopted it as the guiding principle for their actions.

Inge Jens, Dichter zwischen rechts und links, p. I25. See also Mittenzwei, Der Untergang einer Akademie, pp. 119-120; Sontheimer, Antidemokratisches Denken, pp. 73-75. In the early I920s Josef Ponten and Thomas Mann conducted a lively correspondence on this subject, with Ponten clearly favouring the Dichter while Mann was reluctant to draw such sharp distinctions between Dichter and Schriftsteller. See Hans Wysling (ed.), Dichter oder Schriftsteller? Der Briefwechsel zwischen Thomas Mann and Josef Ponten, I9I9-1930 (Bern: Francke, 1988).

17 Kolbenheyer to the Literature Section of the Prussian Academy of Arts, 30.12.1929 in Jens, Dichter zwischen rechts und links, p. 126. 
The Literature Section was, moreover, weakened by its lack of a clear constitution. By the 1930 annual general meeting the situation had become critical. Kolbenheyer reiterated the vollkisch-nationalist case for a German Academy of Literature: 'We need to ask ourselves: Has the German Volk already "authorised" our section, does it recognise it and sanction it ?'19 By turning the emphasis of the Academy's responsibility away from the Prussian state and towards the German people, the völkischnationalist bloc were seeking to counter the 'international' tendencies they perceived in the literary sphere in the Weimar Republic, and in the Academy itself. Seeking to turn the organisation into a German Literature Academy, they opposed the restriction of voting rights to those members resident in Berlin (based on the Academy's position as a Prussian institution), a sign of their opposition to Berlin as the cradle of urban degeneration. They were supported, although for different reasons, by most of their colleagues in the Literature Section. As a resident of Munich Thomas Mann, for example, was not eligible to vote although he had been a founding member.

The decision taken at the meeting in October 1930 to grant voting rights to all members, initially agreed unanimously by those present, significantly strengthened the völkisch-nationalist position. Schäfer, however, irritated many members in a letter accompanying the minutes of a subsequent meeting that he, Döblin and Schickele attended with the Prussian Minister of Culture, Adolf Grimme, at which the decision was apparently given the official seal of approval. He admonished those like Hermann Hesse, who had hitherto maintained a passive membership, triggering Hesse's resignation following its circulation. ${ }^{20}$ Thomas Mann also responded to Schäfer's statement, threatening to

I9 Quoted by Mittenzwei, Der Untergang einer Akademie, p. I25. See also the extract from the minutes of the meeting on 13 th October 1930 in Jens, Dichter zwischen rechts und links, pp. $137-138$.

20 Wilhelm Schäfer, 'Der mißglückte Versuch einer deutschen Dichterakademie' in Die Literarische Welt 7 (1931), Nr. 5, p. 8; see also Jens, Dichter zwischen rechts und links, p. 148 . 
resign if the new ruling was not repealed. ${ }^{21}$ Having initially supported the decision, the Berlin members voiced concerns at the dominant attitude adopted by the nationalist group. In a private meeting on 24 th November 1930, Alfred Döblin, Walter von Molo, Oskar Loerke, Ludwig Fulda and Eduard Stucken declared the new regulations invalid. They were supported by Theodor Däubler and Wilhelm von Scholz. On 17th December 1930 their revised position was made official in the presence of Ministerialrat Dr. Haslinde from the Prussian Ministry of Culture and the völkisch-nationalist victory was reversed on the grounds that it was legally untenable. Kolbenheyer responded on 5th January 193I by resigning from the Section. Schäfer and Strauß followed suit. ${ }^{22}$ Following their exit, Schäfer published an essay in Die Literarische Welt entitled Der mißglückte Versuch einer deutschen Dichterakademie, in which he presented himself and his nationalist colleagues as marginalised, disenfranchised members of the Section. He made it clear that his resignation was not due to the reversal of the decision on voting rights, but to the fact that he no longer saw a way for the Section to develop into a German Literature Academy. ${ }^{23}$ In the press, the developments were viewed, whether positively or negatively, as the victory of republicanism over völkisch-nationalist opposition. This was underlined by the election of Heinrich Mann on 27th January 193I as chairman of the Section. Mann's reputation as a political writer and supporter of the Weimar Republic seemed to confirm the Section as a republican institution, in spite of the election of Rudolf Binding, Gottfried Benn and Ina Seidel alongside Max Mell, Rudolf Pannwitz and Alfons Paquet as new members on 29 th January $1932 .{ }^{24}$

Thomas Mann made his position clear in a letter to Loerke, referred to in Mittenzwei, Der Untergang einer Akademie, p. I28.

22 Ibid., pp. I27-130.

23 Wilhelm Schäfer, 'Der mißglückte Versuch einer deutschen Dichterakademie'; Kolbenheyer also published his version of the events of the previous five years under the heading 'Die Sektion der Dichter an der Berliner Akademie' in the Süddeutsche Monatshefte, 28. Jg. (1930/1931), pp. 519-530.

24 Jens, Dichter zwischen rechts und links, pp. I59-162. 


\section{Gleichschaltung}

The resignations of Kolbenheyer, Schäfer and Strauß and the subsequent identification of the Academy as a republican institution not only influenced the way several völkisch-nationalists responded to the invitation to become members of the Academy under the Nazis, but also informed the speed and manner in which Rust and the Nazis approached the Gleichschaltung of the Literature Section in 1933. The Gleichschaltung of literary institutions began almost immediately after the Nazis took power. The Literature Section of the Prussian Academy of Arts was among the first to undergo the process, partly as a result of a proactive policy of the new government, but also because of actions taken by the members of the Section themselves. ${ }^{25}$

The catalyst for the Gleichschaltung of the Section was the forced resignation of Heinrich Mann as its chairman. This followed the appearance of his name endorsing an appeal by the Internationaler Sozialistischer Kampfbund which appeared across Berlin on I4th February $1933^{26}$ calling for united action by the SPD and KPD against the political events of early 1933. On isth February, Bernhard Rust, now Prussian Minister of Culture, threatened the President of the Academy, Max von Schillings, with its dissolution if Mann was not removed. ${ }^{27}$ In interfering in the affairs of an autonomous cultural organisation, Rust demonstrated the new government's determination to bring all areas of German life under Nazi control. The events that

On the Gleichschaltung of the Literature Section of the Prussian Academy of Arts, see also Walter Huder, 'Die sogenannte Reinigung: Die “Gleichschaltung” der Sektion für Dichtkunst der Preußischen Akademie der Künste 1933', Exilforschung: Ein internationales Jahrbuch. Band 4: Das jüdische Exil und andere Themen (Munich, I986), pp. I48-149.

26 Käthe Kollwitz, artist and member of the Sektion für Bildende Kunst in the Academy, also endorsed the appeal. An article that appeared in the Deutsche Zeitung on 15.2.1933 reported on the speech delivered by Rust at the University of Berlin, in which he assured his audience that he would bring the scandal caused by Mann's signature on the appeal to an end. See Wulf (ed.), Literatur und Dichtung im Dritten Reich, p. I6. 
followed showed no regard for the democratic constitution of the Weimar Republic, under which the Section was formed and which guarded the right of individuals to freedom of speech. Rust's demand for Mann's resignation therefore lacked a legal foundation. It was a challenge to the freedom of the Academy's members to hold and express their private views. While it would remain officially autonomous, from now on the Academy was to be held accountable by the government for the actions and views of its members.

At an extraordinary assembly of the Academy called by Max von Schillings on the evening of 15 th February, a majority of those present accepted Schillings' emphasis on the need to save the Academy. Heinrich Mann did not join the general assembly, but was called for an interview with Schillings and Oskar Loerke. While Loerke's records of this meeting were cursory, ${ }^{28}$ Mann himself summed up the conversation in an interview that appeared in Tempo the next day: 'Schillings endeavoured to justify his position; I told him that it was unnecessary: it was his duty to safeguard the Academy - and it was mine to support him in doing so. I also made it clear to him that I am no communist, but that I had signed this appeal for unity of the left as a republican. I would resign. ${ }^{29}$ Few of those present at the assembly expressed concern at the proceedings. Alfred Döblin's request that Mann be allowed to enter the assembly to give his reasons for resigning was rejected, while Stadtbaurat Martin Wagner's demand for a members' vote on the legitimacy of Schilling's actions was blocked by Gottfried Benn. Following a further defence of Mann from Ludwig Fulda, the meeting was quickly brought to end with the assurance that the Literature Section would meet to discuss the case further. A subsequent meeting five days later did not alter the situation. ${ }^{30}$

'Verhandelt in der Preußischen Akademie der Künste, Sitzung der Gesamtakademie am Mittwoch, den I5. Februar 1933', in Brenner (ed.), Ende einer bürgerlichen KunstInstitution, p. 29.

29 'Erklärungen von Heinrich Mann und Käthe Kollwitz' in Tempo (Berlin), I6.2.1933, in Brenner (ed.), Ende einer bürgerlichen Kunst-Institution, pp. 36-37; see also Wulf (ed.), Literatur und Dichtung im Dritten Reich, pp. 17-19.

30 Hildegard Brenner, 'Beginn der politischen Formierung: Das Ausscheiden von Heinrich Mann und Käthe Kollwitz' in Brenner (ed.), Ende einer bürgerlichen KunstInstitution (Stuttgart, 1972), pp. I4-16, I8-19. 
Following the removal of Heinrich Mann events moved quickly. The same day, Is th February 1933, Hanns Johst, a long-standing and prominent member of the KfdK, published an article in that organisation's newspaper, Deutsche Kultur-Wacht, on the Section's future. His call for the replacement of 'liberal-reactionary writers' like Thomas Mann, Heinrich Mann, Werfel, Kellermann, Fulda and Döblin represented the general attitude of the Nazi leadership. ${ }^{31}$ While there may have been differences of opinion over individual details, not least with regard to the inclusion of Thomas Mann among the unwanted writers, Johst's views were more or less in line with those of many prominent völkisch-nationalist writers waiting to fill the seats of republican and Jewish colleagues whose future in the Academy now looked bleak.

The first phase of the cull of liberal, republican members was initiated in a meeting on I3th March 1933 at which Rudolf Binding took the chair. ${ }^{32}$ Benn once again seized the initiative, proposing that in light of the situation facing the Academy, it should take steps to formalise its position before being subjected to forced measures. He therefore proposed that each member should sign a declaration, which in its final form read:

In recognition of the changed historical situation, are you prepared to continue to make yourself available to the Prussian Academy of Arts? An answer in the affirmative to this question rules out any public action against the government and obliges you to cooperate loyally with the national, cultural tasks that, according to its constitution, fall to the Academy in the spirit of the changed historical situation. ${ }^{33}$

This initiated the resignations of Alfred Döblin, Thomas Mann, Alfons Paquet and, to the regret of those responsible, the conservative Ricarda Huch. In her letter of resignation, Ricarda Huch declared her support for

3I Quoted in Düsterberg, Hanns Johst, p. I68.

32 Only nine members of the Section attended, plus Max von Schillings. Those not resident in Berlin had been dissuaded by being asked to pay their own travel costs.

33 Declaration sent to members of the Sektion für Dichtkunst in the Preußischen Akademie der Künste, 14th March 1933, in Brenner (ed.), Ende einer bürgerlichen Kunst-Institution, p. 60. 
the 'national' task, but refused to endorse any encroachment on the right to the freedom of expression. Attempts by Schillings to change her mind were unsuccessful. Nonetheless, her name continued to appear on lists of members in spite of her repeated protests, a sign of how important the support of suitable writers was to the Nazis. ${ }^{34}$

Further unwanted members were excluded by applying the spirit of the new Gesetz zur Wiederherstellung des Berufsbeamtentums, which stated that non-Aryan and politically oppositional Beamte could no longer remain in the employment of the state. While this did not apply directly to members of the Academy, who were not Beamte, the spirit of the law was adopted in order to expel Leonhard Frank, Ludwig Fulda, Georg Kaiser, Bernhard Kellermann, Alfred Mombert, Rudolf Pannwitz, René Schickele, Fritz von Unruh, Jakob Wassermann and Franz Werfel. ${ }^{35}$

Of the 3I members of the Section at the end of 1932, therefore, Is had now resigned or were expelled. The first phase of Gleichschaltung was completed extraordinarily swiftly, under pressure from the Prussian Ministry of Culture, but with significant co-operation from members of the Section itself. The second phase now began: the rebuilding of the Section with writers who would further the national cause. During the following months, after three rounds of elections, 24 were selected to join (or rejoin) the Section. Among them were many völkisch-nationalists, including Werner Beumelberg, Hans Friedrich Blunck, Hans Grimm, Hanns Johst, Erwin Guido Kolbenheyer, Heinrich Lersch, Agnes Miegel, Börries von Münchhausen, Wilhelm Schäfer, Emil Strauß and Will Vesper. Hans Carossa and Ernst Jünger declined invitations to become members. ${ }^{36}$ Johst was elected as the President of the Section, with Blunck as his deputy and

34 Ricarda Huch's several letters of resignation are reproduced in Wulf (ed.), Literatur und Dichtung im Dritten Reich, pp. 26-27.

35 The correspondence surrounding the resignation and expulsion of these members is reproduced in Brenner (ed.), Ende einer bürgerlichen Kunst-Institution, pp. 58-70.

36 For a full list of members of the Academy at this point see the press release of the Amtlicher Preußischer Pressedienst 9. Juni 1933: 'Tagung der Deutschen Akademie der Dichtung', in Brenner, Ende einer bürgerlichen Kunst-Institution, pp. 86-87. 
Beumelburg as secretary. ${ }^{37}$ A new senate for the Section was also named, comprising Johst, Grimm, Schäfer, Kolbenheyer, Münchhausen, Strauß, Miegel, Blunck and Beumelburg.

\section{A Literature Academy for Germany}

Like Kolbenheyer, Hans Grimm commented on the events in the Academy in his post-war account of the Third Reich, Warum - Woher - Aber Wobin ?38 Reflecting on the re-constitution of the Literature Section, he pointed to the peer selection process to distance those involved in the Academy from the Nazi government and to emphasise its credentials as an independent representative body for 'German' literature. This strategy to claim the legacy of the Academy's historic prestige was adopted by several völkischnationalists after 1945. It was important for their efforts to re-establish their credibility as serious writers in post-war Germany and strongly influenced their accounts of the organisation in the Third Reich.

In 1933, however, it could not be taken for granted that the newly elected writers would accept the invitation to join the Academy. Kolbenheyer was not alone in hesitating. Even writers who were ideologically acceptable to the Nazis were determined to retain the position and autonomy of the Academy, and with it their own influence over the literary sphere. On ıoth May Münchhausen wrote to Grimm, emphasising his willingness to co-operate, but also expressing concerns regarding Rust and the Nazi government. His comment that 'they hold attitude to be more important than artistic accomplishment' highlighted his elitist, even aristocratic vision for the Academy. Echoing völkisch-nationalist objections to the inclusion of Schriftsteller during the Weimar Republic, he was concerned to ensure that membership should not be devalued through the inclusion of

37 Brenner (ed.), Ende einer bürgerlichen Kunst-Institution, p. 21.

38 Grimm, Warum - Woher-Aber Wohin?. 
'dilettante' writers. ${ }^{39}$ In contrast to the Nazi authorities, Münchhausen was not politically dogmatic. He described an academy of thirty members of the German Volk that would work together even if they represented different Weltansschauungen. This was reminiscent of Thomas Mann's original conviction that the Academy should represent the entire spectrum of German literature. Münchhausen's definition of German literature was, however, narrower than Mann's; for Münchhausen race was decisive. ${ }^{40}$

Münchhausen made it clear in his response to Rust's invitation to join the Academy that his main concern was to ensure that the writers therein were worthy of membership, and he believed two of the new members, in particular, to be unworthy: Johst and Beumelburg. Grimm, for one, agreed. Münchhausen also found common ground with his völkischnationalist colleagues over his concern about the space for independent action that would be conferred on the reconstituted Academy. In a letter to the Prussian Minister for Culture in May 1933, he noted that the newspapers had reported that Rust had 'appointed' the new members as the Curator of the Academy. Münchhausen therefore demanded to know whether and to what extent Rust's opinion would count on Academy matters in the future. ${ }^{41}$

During preliminary discussions with Kolbenheyer and other völkischnationalists in the weeks leading up to the constitutional meeting on 7 th June, Rust sought to ensure that he presented the writers with an appealing vision of the Academy's future, and one that appeared to correspond with their ambitions. Following their meeting in Halle in May ${ }^{1933,}{ }^{42}$ Kolbenheyer started work on a plan for the future Academy, as the

Münchhausen to Grimm, I0.5.1933 DLA - A: Grimm, Münchhausen to Grimm, 1927-1945. See also Stephan Malinowski, Vom König zum Führer: Zum Verhältnis von Adel und Nationalsozialismus. Dokumentation einer Veranstaltung am 9. Juli 2004 im Studienzentrum Karl-Marx-Haus in Trier (Trier: Akademie Verlag, 2003).

40 Münchhausen to Grimm, 10.5.1933, DLA - A: Grimm, Münchhausen to Grimm, 1927-I945.

4I Münchhausen to Rust, I0.5.1933, DLA - A: Grimm, Münchhausen to Grimm, 1927-1945.

42 See p. I62. 
Minister had requested. In his autobiography he wrote that he carried his draft programme with him around the cities in which he was lecturing during the week that followed - Rostock, Stralsund, Greifswald, Lübeck, Kiel, Bremen and Bremerhaven - before arriving in Berlin the next weekend for a second meeting with Rust.

This second meeting did not go as Kolbenheyer had hoped; from the moment of his arrival it was clear that things had not developed positively in the week since their initial conversation. Also present this time were Stapel, Schäfer, Stehr, Strauß, Münchhausen, Blunck and Vesper, and Kolbenheyer learned that Hanns Johst and Walter von Molo had both had conversations with Rust during the previous week. Rust delivered an hour-long speech, after which he was visibly pleased with the impression he had apparently made on the assembled writers. According to Kolbenheyer's post-war account, he had, however, only succeeded in dampening their enthusiasm. There was a significant pause before Stehr, the oldest, mumbled that Rust's plans were acceptable. Kolbenheyer nodded his assent. Stapel then summed up the results of Rust's lengthy presentation: the writers would be provided with complete freedom to establish the Academy. Rust confirmed that this was his intention. All that was left, Kolbenheyer concluded, was to decide the date of the constitutional assembly for the new Academy. He did not present his draft programme for the Academy on this occasion.

The business was followed by a cold buffet. In spite of the critical tone of his account, written in the 1950s when Kolbenheyer was seeking to distance his name from association with the Nazis, he was unable to resist noting that the invitation to lunch was a particular honour, being the first reception hosted by the Prussian Ministry of Culture under Rust. Overall, Kolbenheyer nonetheless suggested, this first encounter with the Nazi government was discouraging. He described Rust as a man who had been elevated to a difficult position from his previous occupation as a middle school teacher. He had not been given time to come to terms with the responsibilities of his office. During the meal, Kolbenheyer and Stapel talked to Rust's wife. Kolbenheyer described her as bürgerlich, like her husband, and reluctant to talk about cultural topics. Nonetheless, she was clearly trying to assess the two writers' political views. Rust's adjutant, Zierold, was apparently engaged in similar observation of the other 
guests. Writing after 1945, Kolbenheyer suggests that Frau Rust's verdict was unlikely to have been complimentary. ${ }^{43}$

Predictably perhaps, Kolbenheyer's account of the meeting and subsequent events in the Academy presents its author as a reluctant actor in the organisation, and a consistent critic of the Nazis. At the same time it seeks to suggest that the political scenery was not solely negative; involvement in the Nazi regime, it is implied, did not mean acceptance of or culpability for the negative aspects of the twelve years of National Socialist rule. While claiming to have had a premonition of what was to come, Kolbenheyer concluded that he had been drawn in and now had to see the journey to the end. ${ }^{44}$

Addressing twenty-two of the section's now twenty-eight members at the start of the constitutional meeting held on 7 th and 8th June 1933 in Berlin, Rust, as Prussian Minister of Culture, responded to the newly constituted section positively and sought to allay concerns like those previously expressed by Münchhausen and Kolbenheyer. He stated that the encroachment into the autonomy of the Academy had been necessary in order to bring about something new, but it would not be repeated. He therefore formally returned the Academy's autonomy to its members. Pre-empting the expected transformation of the Prussian Ministry of Culture into a German Ministry of Culture, which never came to fruition, Rust went on to declare that the Prussian Academy of Arts would become a German Academy, responsible as the representative of German literature to the German Volk. In recognition of this, he renamed the 'Sektion für Dichtkunst' the 'Deutsche Akademie der Dichtung. He thus appeared to fulfil the hopes of its völkisch-nationalist members, who had campaigned for this vision since its foundation in $1926 .{ }^{45}$

While Rust formally returned the Academy's autonomy, he did not provide either a legal basis or the institutional space that would have allowed

43 Kolbenheyer, Sebastian Karst, vol. III, pp. 167-169.

44 Ibid. p. 169.

45 Minutes of the Constitutional Meeting of the Literature Section in the Prussian Academy of Arts held in Berlin on 7 th June 1933 in Brenner (ed.), Ende einer bürgerlichen Kunst-Institution, pp. 75-76. 
the Academy to exercise its independence. He ensured that the Academy remained subordinate to him as Prussian Minister of Culture by asserting the need for co-operation with his Ministry and by claiming a continued role for the Nazi state. Sticking to familiar völkisch rhetoric, which emphasised the geistig over more practical legal questions, he avoided addressing questions of the Academy's legal basis and formal competencies. ${ }^{46}$

The Academy's weakness was also apparent in Blunck's suggestion that the members assembled on 7 th June issue a declaration that 'The actions of the Minister regarding the appointment of new members to the Prussian Academy of Arts are retroactively approved. ${ }^{37}$ In accepting this, the members attempted to assert their autonomy, but they were not in a position to reject these changes, to which many of them owed their membership of the Academy in the first place.

A second declaration, also proposed by Blunck and accepted by the members present, made the creation of a German Literature Academy one of the foundations for the Section's future work. This, Blunck suggested, should accord with the model suggested by Kolbenheyer, who proposed a German Academy that would include the ministers of culture of all the Länder as a curatorial body with the Prussian Minister as its chair. ${ }^{48}$ Thus Kolbenheyer hoped to solve the problem of the Literature Academy's dual allegiance to Prussia and to Germany as a whole. Will Vesper pointed out that the question of the Academy was linked to the bigger question of a Reich Ministry of Culture. It was desirable, he argued, that the Prussian Ministry of Culture should be allowed to develop into such an institution. It was, therefore, not the intention of the Literature Section to distance itself from the Prussian Ministry. The assembled members agreed to both proposals. There was also apparent agreement that the new work of the Academy should not be based on the existing constitution. While the Literature Section would remain part of the Prussian Academy of Arts as it had been before - Benn pointed out that a formal dissolution of the

46 Ibid., p. 77.

47 Ibid., p. 79.

48 Ibid., p. 79. 
old section had purposely not been declared - it would develop a new constitution on which its future would be built. ${ }^{49}$

The legal status of the new Literature Academy continued to cause considerable confusion and much debate in the days, months and years that followed. As President of the Prussian Academy of Arts, Schillings consistently sought to maintain the cohesion of its three sections. On Ioth June 1933 he wrote to Ministerialrat Dr. von Staa, the legal and administrative advisor to the Prussian Academy, asking what the legal consequences of the decision to declare the Literature Section of the Prussian Academy of Arts a German Academy of Literature were likely to be. He enquired about the significance of the term reichszuständig (responsible to the Reich), which had been adopted by the Section. ${ }^{50}$ Von Staa's response of I 5 th June declared unequivocally that the decision to change the Section's name to the German Academy of Literature had no immediate legal implications. Likewise the term reichszuständig had little practical meaning as long as the Academy was dependent financially on the Prussian Academy of Arts and therefore the Prussian budget. That being the case, the term could only be interpreted as a statement that all the Volksstämme were represented through their writers in the Literature Section. The decision of the Academy to become a German Academy of Literature could therefore be viewed only as a programmatic declaration. ${ }^{51}$

The meeting of 7 th and 8 th June also highlighted the significant legacy of the Academy's history in the Weimar Republic. In particular, the return of Kolbenheyer, Schäfer and Strauß to the Academy appeared, at least to themselves, to provide an opportunity to reassert their position under more favourable political and cultural circumstances and they brought with them earlier ambitions. These were centred around their desire to make the German Academy of Literature a reality. They found support and sympathy for their position from both the surviving members and those elected to

Ibid., pp. 78-79.

50 Max von Schillings to Ministerialrat Dr. von Staa, Ioth June 1933, in Brenner (ed.), Ende einer bürgerlichen Kunst-Institution, p. 89.

5I Dr. von Staa to von Schillings, Isth June 1933, in Brenner (ed.), Ende einer bürgerlichen Kunst-Institution, pp. 89-90. 
the Academy for the first time. Remembering Paul Ernst, who had died on I3th May 1933, shortly after being called to join the Section, Schillings read from a letter from Ernst's widow: 'In the days of his last illness, the deceased spoke of the difficult task facing the Academy. He was convinced that it had to be a spiritual conscience for the entire German Volk. ${ }^{52}$ The impact of this idea was underlined by Grimm in his reflection on the Academy after 1945, when he repeated this assertion as the guiding principle for the actions of the völkisch-nationalist bloc. ${ }^{53} \mathrm{Hermann}$ Stehr also spoke positively, asserting that the intention to become a German Academy was unreserved and uncontested. For him, the members of the Section now already represented the German Academy; the problem facing them was to make this official.

On 7 th June, Kolbenheyer also finally presented his proposal for a new constitution for a German Academy of Literature. His reminiscences emphasised the continuity with his work in the Academy during the Weimar Republic. ${ }^{54}$ Both the contents of Kolbenheyer's programme and his tenacity in presenting it to the assembled members displayed his deep-seated concern that the new Academy should not suffer from the impotence he felt had plagued the old one, but instead should be effective in representing the pinnacle of German literature, at home and abroad. ${ }^{55}$ Like Münch hausen, he was critical of the mixture of artistic abilities represented among its new members in $1933 .{ }^{56}$ At the centre of his plan was the confirmation of the position and responsibilities of the Senate and the idea of the Academy as the mediator between German literature and the nation. ${ }^{57} \mathrm{He}$ also expressed

52 Minutes of the Constitutional Meeting of the Literature Section in the Prussian Academy of Arts, 7 th June 1933 in Brenner (ed.), Ende einer bürgerlichen KunstInstitution, p. 75 .

53 Grimm, Warum - Woher - Aber Wohin?, p. I62.

54 Kolbenheyer, Sebastian Karst, vol. III, p. 174.

55 Minutes of the Constitutional Meeting of the Literature Section in the Prussian Academy of Arts, 7th June 1933 in Brenner (ed.), Ende einer bürgerlichen Kunst-Institution, pp. 80-83.

56 Kolbenheyer, Sebastian Karst, vol. III, p. 174.

57 Minutes of the Constitutional Meeting of the Literature Section in the Prussian Academy of Arts, 7th June 1933 in Brenner (ed.), Ende einer bürgerlichen KunstInstitution, pp. 80-83. 
concern at the unclear legal basis of the Academy, pointing out that its authority was limited not only by Rust, but by its legal and institutional associations. While it defined itself as a German institution, it retained its previous legal status as part of the Prussian Academy of Arts. As a result, it faced the problem of finding a place within the institutional apparatus of the Third Reich and at the same time its position within the Prussian Academy was undermined. While it remained financially dependent on its parent institution, its remit stretched beyond the Prussian Academy's bounds. ${ }^{58}$

Kolbenheyer's vision for the Academy was, as he observed himself, actually realised more effectively six months later in the form of the Reichsschrifttumskammer under Goebbels. Kolbenheyer criticised the party political nature of that organisation and suggests that Hanns Johst was aware from the start of the direction things were taking behind the scenes in the government ministries. It was quickly clear to Kolbenheyer, according to his post-war account, 'that I [...] was not actually faced by an assembly that had any inclination to engage with the idea of an independent academy of writers. Fundamentally, all that was desired was an institution that would satisfy the vanities [of its members]. ${ }^{159}$

The election of Johst as President of the Literature Academy was evidence of the government's determination to keep that body under its control. Nonetheless, Kolbenheyer and his secessionist colleagues from the old Academy still hoped to rescue the situation. The organisation had no statute once it was accepted that that of the old Prussian Academy of Arts was not valid for a German Academy of Literature. Moreover, Rust had promised the writers that they would have the power to shape the new institution themselves. Thus Kolbenheyer invited Schäfer and Strauß to join him to form a statute commission, along with Johst and Beumelburg, who were included in order to avoid contrivances against the commission's work. ${ }^{60}$

58 Press release of the Amtlicher Preußischer Pressedienst, 9th June 1933: 'Tagung der Deutschen Akademie der Dichtung' in Brenner (ed.), Ende einer bürgerlichen KunstInstitution, pp. 86-87.

59 Kolbenheyer, Sebastian Karst, vol. III, p. 174.

60 Ibid., pp. 174-175. 
After the Second World War, Kolbenheyer described the times in which the new Academy was created as a period of change in which German life was to be transformed into a new reality. The revolution was to touch every corner of German existence. He suggested that he was aware that the uniformity these changes demanded would naturally act against the establishment of an autonomous Literature Academy. It was only possible to understand Rust's promise of freedom, therefore, under the precondition that the institution would 'naturally' conform to the general basis of the new Germany. Nonetheless, defending himself and his colleagues, he stated that unquestioning conformity was likely to contradict the fundamental position of several important members. In taking on the work of providing the Academy with a new constitution, Kolbenheyer therefore wanted to present his colleagues with a statute they could accept, placing the decision-making powers of the Academy in the hands of the Senate. Thus, Johst as President, his deputy and the secretary would be contained as the executive organs of the Senate. Such a plan meant breaking with the Führerprinzip that was increasingly becoming the guiding principle of political organisation in Germany. The discussions over the new statute lasted three months, after which it was unanimously accepted by the members of the Academy. Officially, therefore, by the end of 1933 it provided the legitimate regulatory framework for the Academy. ${ }^{61}$

\section{Disillusionment}

There are a number of similarities between the post-war accounts of the German Literature Academy written by Kolbenheyer and Grimm: both begin the relevant section with a description of the lecture tours they undertook in the first half of 1933 ; both emphasise the non-Nazi nature 
of their vision for the Academy; both present themselves as motivated by a feeling of obligation.

Grimm's account begins with comments on the experience of a lecture tour in Upper Silesia. He talks of his experiences of the bravery and national stoicism of the Germans in Upper Silesia, cut off from Germany after the First World War. He also speaks of his concern for the problems they were facing in 1933 , emphasising in particular their vulnerability to Polish encroachments, both physically and economically, and the inability of the German Reich after the Versailles Treaty to provide sufficient protection to these members of the German Volk. Grimm's reflections on the situation in the region underline his view that radical political change was needed in Germany in $1933 .{ }^{62}$

Similarly, according to Kolbenheyer, the Revolution of 1933 placed the 'geistiger Führer' under increased pressure, presenting him [völkischnationalists always assumed that German leaders were male] with tasks that no political party could prescribe: the geistiger Führer could only be responsible to the Volk if the reactionary character of German life was to give way to action based on clarity of mind and purpose. Thus, German cultural leaders had to act according to their consciences. According to Kolbenheyer's philosophy biological predeterminism governed the emergence of cultural leaders. Thus, their consciences could not be wrong. ${ }^{63}$

The process of Gleichschaltung, out of which the German Literature Academy emerged, by no means settled the form the Academy would take in the years that followed. Among the senators two broad blocs quickly emerged. While their edges were blurred, they can be divided crudely between those writers bent on furthering their political careers and those concerned with völkisch-nationalist writing as Germany's truest and purest contribution to the literary arts. The former were often split further by professional jealousies and competition, and the latter by competing convictions regarding the role of literature and writers in German society. These personal differences only manifested themselves gradually, however,

62 Grimm, Warum - Woher - Aber Wohin? p. I57.

63 Kolbenheyer, 'Die nationale Revolution', p. 436. 
among writers who, already acquainted in many cases, had hitherto seen themselves as part of the same völkisch-nationalist struggle. Therefore, while dissatisfaction was evident from the start, and some of those who had been part of the völkisch-nationalist bloc in the Academy during the Weimar Republic viewed the project pessimistically, the central actors in this phase of the Academy's history initially placed hope in the common ground they saw binding them together.

Before the German Literature Academy had time to find its feet, however, the foundation of the Reichsschrifttumskammer in November 1933 dealt it a definitive external blow. It followed only months after the Academy's reconstitution, unleashing new uncertainties among its members, who had, as we have seen, expected the creation of a Reich Ministry of Culture, led by Rust. This would have provided the Academy with a comfortable institutional home as it too expanded to become the German Academy of Literature. Instead they were faced with a new government institution regulating the literary sphere in Germany under Goebbels in his capacity as President of the RKK and Minister of Propaganda. Within this framework there was no obvious place or function for the Literature Academy. While he did not immediately give up hope for the Academy, Schäfer painted a pessimistic picture of its position in a letter to Grimm in December 1933:

Our Academy was called by the state to be the highest authority in German literature; and the state has put the chair of the highest authority outside the door to its Chamber of Culture. Furthermore, the chair remains standing where we were invited to sit by Rust. With the Reich Chamber of Culture, the Reich Ministry of Culture has been proclaimed by Goebbels instead of Rust; we have been ushered to the wrong chair. ${ }^{64}$

Grimm, on the other hand, was more optimistic. Having accepted an invitation from Goebbels to join the Präsidialrat of the RSK, he defended his decision to Emil Strauß by asserting that the two organisations were functionally separate and could therefore co-exist in harmony. Like Schäfer and Strauß, he saw the role of the Academy to be on a higher plane than that of

64 Schäfer to Grimm, 20.12.1933, DLA - A: Grimm, Schäfer to Grimm, I9II-I935. 
the RSK. Its job was to be the autonomous protector of German literature from corruption and dilettantism, independent of government interference. Its task was to uphold the independence and quality of German literature for the Volk. It should not be a political institution and its competencies did not include the day-to-day administration of the literature industry. That would be left to the RSK. ${ }^{65}$

Grimm's optimism demonstrated the degree to which his belief in the good intentions of the new government at this stage clouded his judgement of their Literaturpolitik. The foundation of the RSK nonetheless showed clearly for the first time the discrepancy between the government's ideas regarding the position and role of literature in German society and that of a large group of völkisch writers now in the Academy. As long as the state believed that the Academy was dependent on it for its survival, Schäfer argued to Grimm, the relationship between state and Academy was false. It would only be put right when the state realised it needed the Academy for its own survival. ${ }^{66}$ Schäfer linked the political survival of the Third Reich with the survival of the völkisch spirit. The goal of politics was to bring about and maintain the spiritual health of the people, from which its physical and economic health were inseparable. To that end, Schäfer and the other völkisch writers showed themselves willing to lend their support to the Nazis only as long as the latter appeared to be achieving this goal.

Ideologically, Grimm's role in the RSK did not fundamentally separate his position on the Academy from that of Schäfer and Strauß. Like Schäfer, Grimm believed that only when the state recognised the need for literature on the part of the Volk would it sign a 'concordat' with 'us', meaning the writers, as its priests. He also agreed, continuing with the religious analogy, that the state would never sign a concordat with individual priests, but only with a church. Therefore, he argued, the Academy had to become a

65 Grimm to Strauß, 21.12.1933, DLA - A: Grimm, Grimm to Binding, 1933-1934, in answer to Strauß to Grimm, I0.12.1933, DLA - A: Grimm, Grimm to Binding, 1933-1934.

Schäfer to Grimm, 20.12.1933, DLA - A: Grimm, Schäfer to Grimm, I911-I935. 
'church'. The state would be ready for such a concordat only in the moment the 'church' existed, for the men governing the state would only interact with opponents who really stood before them: 'Once the Academy church exists, and it can only be created by us, things will immediately be different. They will listen very carefully to the church, and will be only too happy to reach a concordat. ${ }^{36}$ In December 1933, however, Grimm agreed with Schäfer that the Academy was still only a shadow in the eyes of the state and the public.

In spite of the optimistic manner in which the new Deutsche Akademie der Dichtung had approached the new regime, therefore, the months following its initial Gleichschaltung did little more than highlight its lack of purpose. In February 1934, Blunck, now President of the Reichschrifttumskammer (RSK), could point to the nominal transformation of the Prussian section into a German Academy of Literature as its only achievement in the previous twelve months. He went on to suggest that the development of the RSK was of fundamental importance to the Academy, as the former institution would provide representation not only for literary works, but the complete literary profession, from the authors to the booksellers and publishers. At the same time he tendered his resignation as Vice-President of the Academy on the grounds that his responsibilities in the RSK were taking up too much of his time. Blunck thus demonstrated his awareness that the real power in the literary sphere lay in the RSK. ${ }^{68}$ In the course of the next two years his judgement was confirmed as the gap between the aspirations of the Academy's members and the freedom they were allowed by the Nazis irreparably widened. Binding was chosen as his successor as vice-President with the support of the völkisch-nationalist faction that was developing in its ranks. ${ }^{69}$

67 Grimm to Strauß, 21.12.1933, DLA - A: Grimm, Grimm to Binding, 1933-1934. Compare with Schäfer to Grimm, 20.12.1933, DLA - A: Grimm, Schäfer to Grimm, I9II-1935.

68 Blunck, confidential report on Preußische Akademie der Künste and Reichsschrifttumskammer, II. Hornung (February), I934, B.Arch.NS8-ıо .

69 Grimm to Binding, 4.3.1934, DLA - A: Grimm, Grimm to Binding, 1933-1934. 


\section{The 'Munich Consensus'}

As the weakness of the Academy became apparent, six writers (Hans Grimm, Rudolf G. Binding, Erwin Guido Kolbenheyer, Wilhelm Schäfer, Emil Strauß and Börries von Münch hausen) increasingly displayed the symptoms associated by scholars with 'inner emigration. They referred to themselves as the 'Munich Consensus' or Münchner, denoting the informal but close nature of their association, which arose from a series of meetings held in Munich beginning in 1934. Their partial retreat from public life towards the end of the r930s has led historians, including Hildegard Brenner and Jan-Peter Barbian, to conclude that the Academy was increasingly insignificant in the Third Reich. ${ }^{70}$ On the other hand an unexpectedly advanced degree of intellectual opposition to the policies of the Nazi regime can also be seen among these same writers, despite the fact that they have typically been held to have represented the Third Reich in the literary sphere, both by their contemporaries and by later commentators. This opposition never amounted to outright resistance however; they were not alienated by the Nazi ideology or programme, but by the popular character of the Nazi movement and the failure of its leaders to recognise them above the masses. As the self-appointed literary judges in Germany, their antagonism towards the regime also possessed a moralising character as they sought to prevent German literature from degenerating into a political tool.

The formation of a group like the Munich Consensus within the literary structures of the Third Reich was made possible by the Academy's marginal position in the institutional landscape of the regime. Having allowed the Academy little influence, the Nazis seem to have paid the private associations of its members little attention. As long as they did not appear to be contaminating the wider public with ideas that conflicted with the ideology of the regime they could be considered safely contained in the Academy. From the government's point of view, moreover, their

70 Brenner, Ende einer bürgerlichen Kunst-Institution, Introduction; Barbian, Literaturpolitik, pp. 7I-79. 
presence in the Academy was a sufficient public endorsement of the regime by the nation's leading völkisch-nationalist writers. Paradoxically, it was the Academy itself that allowed their opposition to grow by providing a space in which they could discuss and exchange ideas. Even after the Academy had finally descended into political oblivion, these networks did not die out, but instead found new, less formal outlets for their expression. This was in part due to the role the Academy played in their development in the four years immediately following the Nazi Machtergreifung.

By the time the members of the 'Munich Consensus' were called to join the Academy, they were all in advanced middle age, if not elderly. With their most productive years of work already behind them, they were set in their ways and opinionated. Well established as the writers of the German right, they represented the völkisch literary tradition in the Third Reich. They were elitist and independent, refusing to bow without protest to the dictates of the Nazi government or to the demands of colleagues in the Academy. They believed they belonged to the organisation through 'God's grace' rather than earthly appointment. ${ }^{71}$ Although their approaches to the issues they faced and their reactions to specific events often differed, the concerns of the members of the 'Munich Consensus' for the Academy and their belief in the role of German literature and the responsibility of German writers to the Volk provided them with a common foundation. They were bound together by their determination to create their version of a völkisch-nationalist state, which conformed to the völkisch model developed from the end of the nineteenth century. Finally, their associations from the pre-1933 era meant that their relationships were not based wholly in the Academy context. As a result their correspondence indicates a degree of trust that allowed sometimes surprisingly candid interactions. ${ }^{72}$

In addition to their common vision of the importance of völkisch literature for the future of Germany, the second major factor holding the

7I Grimm to Schäfer, 25.3.1934, DLA - A: Grimm, Grimm to Binding, 1933-1934.

72 See, for example, Kolbenheyer to Grimm, II.9.1933, DLA - A: Grimm, Kolbenheyer to Grimm, I918-1938. Also undated letter from 1933 from Grimm to Kolbenheyer in DLA: Nachlaß Grimm, Grimm to Kolbenheyer, 1933-1959. 
Munich Consensus together was a feeling of dissatisfaction. The Munich Consensus grew out of and was an expression of the increasing antipathy of a group of leading völkisch-nationalist writers towards the Nazi regime. As early as July 1933, Grimm wrote to Binding: 'I feel too tormented by the times I myself so longed for. But exactly because I longed for them I also feel responsible for their dreadfulness, for their tortuous, useless dreadfulness. ${ }^{173}$ In the same letter, he described his disappointment in the Academy after the constitutional meetings of 7 th and 8th June, expressing his dissatisfaction at the way in which competencies had been defined and offices distributed before the Academy was in possession of sufficient power to act. ${ }^{74}$ Any encouragement he gained from further meetings in October 1933, which indicated an improvement in the situation, was short-lived. In spite of Grimm's initial welcome for the RSK, it was not long before its foundation had more or less crushed the optimism of the six writers, casting its shadow over the Academy. ${ }^{75}$ Nonetheless, their sense of responsibility not only for the shortcomings of the nationalist state but also towards the German Volk, to whom the Academy was accountable, drove them on. ${ }^{76}$ What began as a casual alliance in Academy meetings gradually became a recognisable bloc that increasingly stood apart from the more pragmatic politics of National Socialism, which left its members disillusioned and bitter.

Mittenzwei suggests that the 'Munich Consensus' was formed out of a 'Kreis um Münchhausen', or Münchhausen Circle, in the Academy. He places particular emphasis on the role of Münchhausen not only in the Academy, but also with regard to the relative influence of the writers in question on the literary sphere in the Third Reich as a whole. ${ }^{77}$ Münchhausen was indeed a significant figure in the völkisch-nationalist

Grimm to Binding, 5.7.1933, DLA - A: Grimm, Grimm to Binding, 1933-1934. Ibid.

Grimm to Strauß, 21.12.1933, DLA - A: Grimm, Grimm to Binding, 1933-1934. Further expressions of the dissatisfaction of the Münchner writers with the regime were evident, for example in Kolbenheyer to Grimm, 26.4.1934, DLA - A: Grimm, Kolbenheyer to Grimm, 1918-1938.

77 Mittenzwei, Der Untergang einer Akademie, pp. 322-323. 
literary networks of the I920s and early I930s. His family connections, legal training and diplomatic manner enabled him to maintain contacts with many important literary and political figures. His völkisch-nationalist worldview, particularly the racist views he cultivated in the second half of his life, drew on a long family history and aristocratic upbringing which distinguished him from his colleagues in the Munich Consensus. His worldview was influenced by the attempt to reconcile the milieu from which he came with the world in which he lived. By 1933 he had moved far from the Bohemian circles in Berlin in which he moved in the first decade of the twentieth century. There, he had counted a number of Jews among his close friends. During the Third Reich, he took pains to distance himself from Juda, the anthology of ballads with Jewish themes he had published in 1900 and dedicated to the artist Ephraim Moses Lilien, who provided the illustrations. ${ }^{78}$ His increasingly conservative point of view and retreat from the city to his family estate at Windischleuba after the First World War were accompanied by the cultivation of an anti-Semitism that made him susceptible to National Socialism. Nonetheless, he particularly objected to the mass character of that movement. ${ }^{79}$ As we have seen, his aristocratic views also shaped his attitude to the Academy.

Münchhausen's literary renown was based on his success as one of the revivers of the German ballad in the first decade of the twentieth century. His prominence as a poet had, however, already faded by 1920 when modernist forms of literary expression, particularly expressionism, overtook his nostalgic style. ${ }^{80}$ While he remained active in völkisch-nationalist circles during the Weimar Republic and Third Reich, on the literary front both Hans Grimm and Erwin Guido Kolbenheyer were more significant after 1918. While Kolbenheyer was the recipient of the largest number of literary prizes of any writer during the Third Reich, ${ }^{81}$ Hans Grimm's identification

78 Börries von Münchhausen, Juda: Gesänge (Berlin: Fleischel, 1900); Mittenzwei, Der Untergang einer Akademie, pp. 161-162, 373-374.

79 For Mittenzwei's summary of Münchhausen's early ideological development see Der Untergang einer Akademie, pp. 157-165.

80 Sarkowicz and Mentzer, Literatur in Nazi-Deutschland, p. 288.

8I Ibid., pp. 243-244. 
as a political writer even before 1933 made his public support for the Nazis a significant prize for Goebbels. ${ }^{82}$ As a result, Grimm was rewarded in 1933 with his appointment to the Präsidialrat of the RSK. Münchhausen was, like Grimm, invited to join the Literature Academy, but he received little further recognition from the Nazi leadership.

Grimm's best-selling novel Volk ohne Raum was among the most famous völkisch-nationalist works to emerge in the Weimar Republic. ${ }^{83}$ Its ca.1350 pages engaged directly with Germany's ills and its success even surpassed that of Kolbenheyer's Paracelsus-Trilogie, a work that also gained recognition for its author following its appearance in three volumes in 1917 , I92I and 1925 respectively. Finally, while Grimm's publicly critical views of the Nazi regime, coupled with his continuous activity and the success of his Lippoldsberger Dichtertreffen between 1934 and 1939 caused him to fall from grace with the Nazi rulers, in particular Goebbels, they also meant that he retained a greater degree of independence than Münchhausen during the Third Reich. In particular, the Lippoldsberger Dichtertreffen not only remained independent of Nazi influences, unlike Münchhausen's Wartburg Dichtertage, but also attracted widespread public attention. ${ }^{84} \mathrm{Grimm}$ cannot therefore be written off as either a 'Don Quichote' or 'Querulant' among völkisch-nationalists, as Mittenzwei suggests; ${ }^{85}$ the impact of his activities meant that he was a greater force to be reckoned with after 1933 than Münchhausen.

With regard to the other members of the Munich Consensus, Münchhausen was more actively engaged in the political sphere than either Schäfer or Strauß, both of whom were older than he was. He also compromised his position with regard to the Nazis to a greater degree than his colleagues. While Strauß was the only member of the Munich Consensus who belonged to the NSDAP, this was little more than a sign of his initial enthusiasm for the Nazis in the early 1930s. He was not active in the Party.

82 See chapter two, pp. I55-157. Münchhausen is not, moreover, mentioned in Goebbels' diaries.

83 Mittenzwei, Der Untergang einer Akademie, pp. I9I-I95.

84 See Chapter 4.

85 Mittenzwei, Der Untergang einer Akademie. p. 377. 
In comparison, Münchhausen worked hard, although not always successfully, to cultivate his acquaintances in the government, and appears to have been more open to the possibilities offered by the regime. His faith in Hitler remained strong up to $1945 .{ }^{86}$ In the final weeks of the war, he took his own life, rather than experience Germany's defeat.

Schäfer produced little new work after 1933, but he continued to lecture to audiences across Germany. Sarckowicz and Mentzer quote a speech he gave at the Großdeutsches Dichtertreffen in Weimar in 1942 as evidence of his consistent support for the NSDAP. It is, however, important not to rush to this conclusion. The outbreak of the Second World War had provided him with the opportunity to reconcile himself with the regime by allowing him to concentrate on a familiar subject, namely war. In his speech, Krieg und Dichtung Schäfer drew on themes of war, literature and the German Volk that he had already addressed in Die dreizehn Bücher der deutschen Seele in $1922 .{ }^{87}$ In discussions over the Academy, however, Schäfer was among the first to express doubts about its situation. Alongside Grimm and Kolbenheyer his was among the loudest critical voices in the group.

Finally, the absence of Nazi representation at Binding's funeral in 1938 should not be viewed as a sign of him lacking impact in Germany in the years before his death. Binding was consistently referred to with respect in newspapers and literary journals for his honourable character, and his work enjoyed steady success throughout the period.$^{88}$ Like Grimm and Kolbenheyer, Binding maintained a worldview independent of that propagated by the Nazis. Mittenzwei argues that he was the outsider in the Munich Consensus, who never succeeded in gaining the absolute trust of his colleagues. ${ }^{89}$ If the contacts of the writers outside the Academy context are examined, however, a different picture emerges. In particular the correspondence of Grimm and Binding is evidence of the honest and

87 Wilhelm Schäfer, Krieg und Dichtung (Weimar: Gesellschaft der Bibliophilen, 1944); see also Sarckowicz and Mentzer, Literatur in Nazi-Deutschland, p. 303 and the discussion of Die dreizehn Bücher der deutschen Seele in this volume, pp. 81-83. Sarkowicz and Mentzer, Literatur in Nazi-Deutschland, pp. 99-100.

89 Mittenzwei, Der Untergang einer Akademie, p. 327. 
open communication between the two men and a personal friendship that extended into their private lives. ${ }^{90}$

The Munich Consensus understood itself as an informal alliance of like-minded equals. Nonetheless, considering the impact of the individual members of the 'Munich Consensus' on the Literature Academy, in practice Hans Grimm, not Münchhausen, proved the most influential figure, in so far as the nature of their cooperation allowed or required anyone to adopt a leadership role. ${ }^{11} \mathrm{He}$ turned his dissatisfaction with the regime into action more effectively than many, providing the Munich Consensus with much of its momentum. Alongside Grimm, Binding played an important role as Blunck's successor as Vice-President of the Academy, seeking to shape that institution according to völkisch-nationalist principles. More generally, the question of the position of the Academy in the Third Reich led to general friction between the Munich Consensus and the Nazi rulers. In this respect, however, Münchhausen was the least independent of the regime, and the least affected. In spite of his contacts with a number of figures on the second rung of the government ladder, men like Schulte-Strathaus and Paul Schultze-Naumburg, his influence in völkisch-nationalist circles, and on the wider public, waned. ${ }^{92}$

The members of the Munich Consensus shared an ongoing sense of crisis that was never resolved in the Third Reich. Instead, it was further

90 For example, in a letter on 4.7.1937 Grimm thanked Binding for the hospitality the latter showed Grimm's son, Wernt, who stayed with Binding in connection with a Hitler Youth trip to Bavaria, DLA - A: Grimm, Grimm to Binding, 1936-1937.

9I Börries von Münchhausen's Nachlaß is spread over six locations: The Goethe-Schiller Archive, Weimar; the Thüringer Universitäts- und Landesbibliothek, Jena; the Staatsbibliothek Berlin; the Deutsches Literaturarchiv, Marbach am Neckar; the Thüringisches Staatsarchiv, Altenburg; the Staats- und Universitätsbibliothek Göttingen. The holdings in Weimar and Altenburg are concerned with his estates and the Marbach collection is restricted to a limited amount of correspondence and some manuscripts. Likewise, the university library in Göttingen possesses only a small number of letters from Münchhausen. An examination of the family correspondence in the Staatsbibliothek in Berlin and his correspondence with Hans Grimm in Marbach, has contributed to the conclusions presented here, alongside Mittenzwei's account, which is based on research in the Münchhausen archive in Jena. See Chapter 4. 
exacerbated by personal differences in the Academy, as the Münchner increasingly defined themselves against the political ambitions of Johst and Blunck. In particular, dissatisfaction with Johst's leadership added grist to their mill. Initially, during the first year of the reconstituted Academy's life, they sought to deal with the differences of its members by differentiating between the personal and the professional. Münchhausen therefore complained of Johst's inclusion in the Academy on the grounds that he had not proved his worth as a writer. Nonetheless, he still rated him highly as a person and was willing to concede that he had demonstrated literary potential. ${ }^{93}$ Grimm too was critical of Johst's style of leadership as President of the Literature Academy, but he nonetheless wrote to Binding on 23rd April 1934: 'I too feel myself personally bound to Johst.'

In the course of 1934 , however, relations deteriorated. In a Rundschreiben circulated among the senators of the Literature Academy on I2 th January 1934, Johst took the opportunity to reprimand those members of the Senate who had suggested that the Academy 'is hanging in the air' or that it was questionable 'whether the Academy still exists at all'. He demanded a more constructive attitude and a united front among its members. $\mathrm{He}$ was determined there should be no doubt that in the future such divisions would not be tolerated. The president, his deputy and the secretary required absolute co-operation in building up the Academy from all its members. They should therefore refrain from pushing for rushed decisions and voicing criticism that endangered the Academy. ${ }^{95}$

Münchhausen to Grimm, I0.5.1933, DLA - A: Grimm, Münchhausen to Grimm, 1927-1945.

94 Grimm to Binding, 13.4.1934, DLA - A: Grimm, Grimm to Binding, 1933-1934.

95 Extracts of the Rundschreiben from Johst of I2.I.1934 were included in a letter from Grimm to Binding of 23.4.1934, DLA - A: Grimm, Grimm to Binding, 1933-1934. At the time Johst wrote the Rundschreiben, Binding had not yet been appointed as his deputy and was still the only member of the Munich Consensus not on the Senate. In order to keep him up to date with Academy affairs, the other Münchner regularly informed him of developments, a further sign of the significant strength in the cooperation of the six men. In particular Grimm adopted this task, reflecting the friendship that already existed between the two men. 
Instead of achieving the desired end, Johst's demands elicited an angry response from the Münchner. Schäfer wrote informally to Grimm for reassurance: 'I am writing this letter to you personally, without keeping a copy for myself, because I want nothing more than a human word from you: namely, whether you still believe in the possibility of maintaining more than just a fiction of a German Literature Academy. I can almost no longer do so [...]. ${ }^{96}$ Grimm's response to Schäfer, written the following day, demonstrated a more hopeful attitude. He admitted that he had not seen a copy of Johst's Rundschreiben, but, having just returned from Berlin, he assured Schäfer of his continued belief in the role and importance of the Academy: 'At the meeting of the [Reich] Chamber [of Literature] the Academy was mentioned several times, and was mentioned with respect as a sort of highest authority.' A campaign by a group of young writers against the LangenMüller-Verlag, which published the works of both Grimm and Schäfer, and against older writers and academicians, he argued, showed that the need for the Academy to uphold the standards of German literature was greater than ever. In order for the Academy to meet this need, however, greater communication and co-operation was required between its members. ${ }^{97}$

Less than two months later, however, Grimm too found occasion to criticise Johst, who, without consulting the other senators, had allowed Blunck to rejoin the Senate after his resignation as Vice-President. Grimm described his behaviour as the exercise of the Kommandoprinzip, which he argued was unacceptable in an Academy of equals. ${ }^{98}$ In response to these perceived grievances, Grimm intensified his demands for the formation of a clear programme for the German Literature Academy. Only when it could clearly present its position, he argued, would it be taken seriously by the government. ${ }^{99}$ To this end, on 25 th February 1934 he suggested a private meeting of those members of the Academy whose views were closest to his own in order to form a common position and enable them to

96 Schäfer to Grimm, 24.I.1934, DLA - A: Grimm, Schäfer to Grimm, I9II-I935.

97 Grimm to Schäfer, 25.1.1934, DLA - A: Grimm, Grimm to Schäfer, 1928-1950.

98 Grimm to Schäfer, 25.3.1934, DLA - A: Grimm, Grimm to Binding, 1933-1934; Grimm to Binding, 4.3. 1934, DLA - A: Grimm, Grimm to Binding, 1933-1934. Grimm to Strauß, 21.12.1933, DLA - A: Grimm, Grimm to Binding, 1933-1934. 
present a united front in Academy meetings. ${ }^{100} \mathrm{~A}$ week later Grimm again emphasised the importance of co-operative action in a letter to Binding, in which he went as far as to demand that they be prepared to resign their seats in the Senate should they fail to arrive at a satisfactory arrangement for the Literature Academy. ${ }^{101}$

Grimm was not alone in promoting the joint action of those who believed as he did, and thus the foundation of the Munich Consensus was laid. It was the result of a real agreement among its six members to build on the similarities rather than emphasise the differences in their visions for Germany and German literature. They thus entered into combat against the threat posed by those whose ambitions were not focused on the best interests of the German Geist and the German Volk. The Munich Consensus met for the first time on 29th March 1934 in the Regina Palace Hotel in Munich. At the meeting, which lasted, according to Münchhausen's minutes, from ten o'clock in the morning until nine-thirty at night, a number of issues were brought to the table, concerns which had developed since the reconstitution of the Academy and which would continue to dominate their discussions in the years that followed. These included their dissatisfaction with Johst's leadership, Kolbenheyer's unratified constitution, as well as the position and autonomy of the Academy in the institutional framework of the Third Reich and in the public eye. ${ }^{102}$

The Munich Consensus continued to hold Johst responsible for the failing Academy. On 5 th July 1934 Binding wrote to his five Munich colleagues to lend support to the suggestion initiated by Kolbenheyer and Grimm that the Münchner should meet for a second time. He argued that the meeting should take place immediately; swift action was necessary if they were to pull the Academy out of its frozen state. Johst, he argued, was incapable of protecting their interests; he lacked the courage and sharpness

I00 Grimm to Schäfer, 25.2.1934, DLA - A: Grimm, Grimm to Binding, 1933-1934. As became the common practice among the Münchner, Grimm also sent copies of this correspondence to Binding, Strauß, Münchhausen and Kolbenheyer.

IoI Grimm to Binding, 4.3.1934, DLA - A: Grimm, Grimm to Binding, I933-1934.

IO2 Mittenzwei, Der Untergang einer Akademie, pp.321-332; for details of the meeting, see pp. 327-328. 
required to bring the necessary weight to the questions of the Academy and was a liability to its future. ${ }^{103}$

Binding's reservations concerning Johst's leadership continued after the latter's appointment as President of the RSK in 1935. While Binding identified this as an opportunity to bring about an improvement in relations between the Academy and the RSK, he was not hopeful that this would be the outcome. ${ }^{104}$ In general, by the end of 1935 the Munich Consensus had lost faith in Johst's motivation to find a cure for the Academy's ills. While they rated him more highly than Blunck, there was little chance that he would use his appointment as President of the RSK to bring about a substantial improvement in the Academy's position. As Blunck's case had shown, the Academy was of no use to Johst's political ambitions once he was in control of the RSK. ${ }^{105}$

Relations between the Münchner and Johst, however bad they became, nonetheless began on a basis of respect for his work, contrasting significantly with their attitude towards Blunck. In a letter of sth January 1935 Grimm wrote to Binding, congratulating him on the sale of 15,000 copies of his new book between 2 Ist November 1934 and Christmas. In comparison, he wrote of Blunck's latest effort: 'I have also received the unmatched "Blunckification" of the Nibelungenlied. I have not yet sent my thanks for it; I am uncertain how to do so.' ${ }^{106}$ Binding was also critical of Blunck's work, asserting that he was a provincial writer, the sort promoted by the Nazis to reach out to the German middle classes on their own level. ${ }^{107}$ His letter highlights a further discrepancy between the Münchner and the regime. Contrasting themselves to Blunck, they saw themselves as German writers whose literature represented the spirit of the German Volk not only in Germany but also to the world.

IO3 Binding to Munich Consensus, 5.7.1934, DLA - A: Grimm, Binding to Grimm, 1933-1934.

I04 Binding to Grimm, 21.11.1935, DLA - A: Grimm, Binding to Grimm, 1935-1936.

I05 Grimm to Binding, 22.11.1935, DLA - A: Grimm, Grimm to Binding, I935.

I06 Grimm to Binding, 5.1.1935, DLA - A: Grimm, Grimm to Binding, 1935, with reference to Blunck, Das Nibelungenlied: mit Bildern aus der hundeshagenschen Handschrift (Leipzig: Bibliographisches Institut, 1934).

107 Binding to Grimm, I0.5.1935, DLA - A: Grimm, Binding to Grimm, 1935-1936. 
The character of the Munich Consensus was informed to a significant extent by the memory of the earlier alliance of Kolbenheyer, Strauß and Schäfer in the Academy before 1933. After its Gleichschaltung these men re-engaged in the Academy with the assumption that they would work together. In spite of their doubts about their position, they understood the period as one of on-going revolution and, for as long as their long-term aspirations remained focused on the Nazi regime, they maintained the hope that these weaknesses could be remedied. With hindsight, there was something quixotic about the meeting in March 1934, and subsequent meetings at which the writers attempted to form a group that could influence events positively from a völkisch standpoint. They acted in the belief that they had some power over the future of the Literature Academy. In fact, as the final outcome showed, they did not. The rhetoric of the völkisch-nationalist ideology nonetheless provided them with the rationale for continued action. As Grimm wrote to Binding on 4th March 1934, they were compelled to act because "The "Führerprinzip" grants the active everything, the passive nothing. I have not yet known it to be different. ${ }^{108}$ It allowed them, too, to hold onto the belief that Academy members were equal. Grimm therefore declared that if they insisted on their position, Johst would have to change the style of his leadership. The job of the President of the Academy, he said, was to act as the liaison officer between the Academy and the state. ${ }^{109}$

\section{'Standesvertretung'}

The question of leadership was also a dominant theme in a lecture by Kolbenheyer that was banned by the authorities in Leipzig and Dresden in early 1934, with the intention that the ban should be valid across the

Io8 Grimm to Binding, 4.3.1934, DLA - A: Grimm, Grimm to Binding, 1933-1934. I09 Ibid. 
German Reich. ${ }^{110}$ By the time the ban came into force, Kolbenheyer had already delivered the lecture in several German towns. Its publication under the title Der Lebensstand der geistig Schaffenden und das neue Deutschland was, moreover, unaffected. ${ }^{111}$ As a result, the ban was greeted by Kolbenheyer with indignation and by his Munich Consensus colleagues with incomprehension. Grimm noted to Schäfer that the content of the lecture appeared to be no different from thoughts voiced by Goebbels around the same period. ${ }^{112}$ This case therefore provides evidence of the way in which the members of the Munich Consensus interpreted the Nazi programme and an example of the ideas that underpinned their approach to the German Literature Academy.

Responding to an enquiry from his publisher in 1934, Kolbenheyer described the events surrounding the ban. According to his account, he had already delivered the lecture to great acclaim in nine towns when the leader of the student organisation at the University of Leipzig handed him a letter asking him to cancel his planned appearance at that institution, the university authorities fearing it would provoke unrest. Kolbenheyer pointed out that the speech had not previously caused disruption. Only in Munich and Jena had he encountered criticism, and this was laid aside during the public discussion that followed the formal lecture. He was later told by a journalist at the Völkischer Beobachter that the opponents he had encountered in Munich had taken their complaints to Minister Schemm, in charge of Culture and Education in Bavaria, who was then instrumental in pursuing the ban. ${ }^{13}$ Kolbenheyer's private notes suggest,

IIo Grimm to Schäfer, II.2.1934, DLA - A: Grimm, Grimm to Schäfer, 1928-1950.

III Erwin Guido Kolbenheyer, Der Lebensstand der geistig Schaffenden und das neue Deutschland (Munich: Langen-Müller, 1934).

I12 Grimm to Schäfer, II.2.1934, DLA - A: Grimm, Grimm to Schäfer, 1928-I950. Grimm also wrote a letter to the Secretary of the Academy, Werner Beumelburg, in which he defended Kolbenheyer's speech, also in the name of Münchhausen: Grimm to Schriftführer der Deutschen Akademie der Dichtung, I8.2.1934, DLA - A: Grimm, Kolbenheyer - Erklärungen zu einem Vortragsverbot, 1934.

II3 E.G. Kolbenheyer 'Ueber Anfrage des Albert Langen / Georg Müller Verlages [...]', DLA - A: Grimm, Kolbenheyer - Erklärungen zu einem Vortragsverbot, 1934. 
however, that Schemm himself attended the lecture in Munich, took part in the discussion, applauded vigorously and had even reported to a third person that he found it good.

It therefore remained unclear to Kolbenheyer where the objections to his speech in the Saxon cities had come from. ${ }^{114}$ The lecture appears to have aroused a suspicion that Kolbenheyer had accused Hitler of being insufficiently intellectual. Kolbenheyer countered this idea in his statement for his publisher: far from insulting Hitler, he had emphasised his gifts as a politician. He had suggested that Hitler's great revolutionary deeds were of a political nature, not intellectual, ${ }^{115}$ and asserted that he was the victim of a misunderstanding; none of the Saxon authorities responsible had actually heard the speech or had first-hand knowledge of its content.

In his lecture, Kolbenheyer sought to solve the problems he identified in Germany by developing the idea of society based on the concept of the Stand or estate. He explained the division of society into estates in biological terms typical of the pseudo-scientific, social-Darwinist ideals that pervaded German intellectual activity, including the literary arts, in the Third Reich. There were, according to Kolbenheyer, four estates: the peasantry ('Bauerntum'), the workers ('Arbeitertum'), the administrators and executors ('Verwaltungs- und Verkehrsstand') and finally the spiritually creative ('der Stand der geistig Schaffenden'). ${ }^{116}$ An individual's place and function in society was inherited. One of the problems with democratic thought, he argued, was its failure to recognise this. Its emphasis on the individual equality of all people suggested a biological equality, which in turn led to class struggle. ${ }^{117}$ 'Biological socialism', as Kolbenheyer called his theory, on the other hand differentiated between functional groups built up genetically over generations as organs of the body of the Volk. It was through the co-operation of these biologically defined Lebensstände

II 4 'Notizen über das Verbot des Vortrages: "Der Lebensstand der geistig Schaffenden und das neue Deutschland”', Solln, den 24.I.34, signed by Kolbenheyer, DLA - A: Grimm, Kolbenheyer - Erklärungen zu einem Vortragsverbot, 1934.

II E.G. Kolbenheyer 'Ueber Anfrage des Albert Langen / Georg Müller Verlages [...].'

II 6 Kolbenheyer, Der Lebensstand, p. I4.

II7 Ibid., pp. IO-I5. 
that society could function as an organic whole. ${ }^{118}$ Therefore, individuals had no right to choose their place in society, only the right and duty to fulfil their biologically determined task through their Lebensstand. This, he argued, was nationalism in its highest and most enlightened form. ${ }^{119}$

Kolbenheyer went on to argue that the time had come for the spiritually creative to recognise and fulfil their particular purpose within this social structure. Here he warned of mixing Geistigkeit with Intellektualismus, the latter being an evil of the republican age while the former was vital, particularly in this critical moment in the development of the Volk:

The spiritual creators are a vital element in the Volk. We must therefore speak of an estate of the spiritually creative in the fullest biological meaning of the word. - The estate of German bearers of the Geist has to be normatively maintained and perpetuated on its natural path through the recognition of developments in the life of the nation in all areas of the cultural and civilised sphere. ${ }^{120}$

Should the German Volk lose the ability to provide cultural leadership for the white race, Kolbenheyer continued, it would sink to a level at which it was vulnerable to the onslaught of its enemies. It is possible to infer that these included the usual targets of völkisch-nationalism, including the Jews, Republicans, Bolshevists, and Freemasons.

Having established the importance of the Stand der geistig Schaffenden, Kolbenheyer asked who should function as the Führer of the estate. It was time, he said, that a differentiation was made between Führertum and Kommando. The latter was an allotted task, making its holder responsible for leadership within the framework of an organisation. It did not, therefore, require leadership characteristics, just knowledge and decisiveness in order to maintain the organisation in its function. The Kommandant'does not create the organisation, he moves it and maintains it in appropriate readiness.' By contrast the Führer created the organisation, which provided him with a tool to use in creative acts. While a Kommandant could be

II 8 Ibid., p. II.

II9 Ibid., p. II.

I20 Ibid., p. I4. 
trained and allocated his role, the qualities of a Führer could not be learnt, but were innate to his being. These qualities would be apparent to his followers through his achievements, which would earn him his position. ${ }^{121}$

When applied to the Academy, the role of the Kommandant was exercised by the President, in this case Johst, who was ultimately responsible for the organisation's smooth operation. On the other hand, Kolbenheyer claimed for himself and his colleagues the same rights as those on which the Nazis based their rule. The members of the Academy did not owe their position to any authority, but to their lifetime achievements for their Volk, giving them the right not only to autonomous regulation, but also to pronounce on literary matters in the whole Reich. Kolbenheyer and his colleagues were therefore to be represented as the Stand der geistig Schaffenden in the Academy. In their eyes it would thus fulfil its responsibility to the German Volk emphasised by Rust in his speech on 7 th June $1933 .{ }^{122}$ By enabling the estate to carry out its duty in the organic whole that made up the Volk, the Academy would contribute to the overall wellbeing of the latter. These were also the principles that formed the basis of Kolbenheyer's vision for the Academy outlined in his draft constitution. Such a view of the Volksgemeinschaft was, however, dangerous to the Nazis as it negated the power of the government to decide on intellectual or artistic matters.

The idea that writers formed an estate in German society and that the Academy should act as the representative body of this estate was common ground in the rhetoric of Nazi politics. It was, therefore, not unreasonable for the Münchner to think in these terms also. In his letter of resignation as Vice-President of the Academy, Blunck referred to the 'ständische Neuordnung' (reordering according to estate) of Germany, which in the cultural sphere, he suggested, was carried out through the foundation of the RKK and its subordinate chambers. Within this reorganisation, he declared, the members of the Academy pledged their loyalty to the Führer. He went on to say that the 'ständische Neuordnung' brought with it both dangers and advantages for German literature. The greatest advantage 
was that in the future police intervention to regulate the estate, while remaining a characteristic of the western democracies, would give way to self-regulation, requiring self-observation and the protection of their own honour and values. The supervision of literature would be the job of the RSK, with the expert advice of the Academy. Blunck therefore ascribed to the Academy an advisory role in the regulation of German literature. ${ }^{123}$

The Münchner viewed the situation differently. Grimm, for example, differentiated between the Stand and the Büro, the former being represented by the Academy, while the latter was manifested in the RSK. ${ }^{124}$ Binding commented that this differentiation was so self-evident it was difficult to understand how the Büro could see itself as the Stand. Implicit here was a criticism of Blunck and the RSK, which he felt had failed to take proper notice of these differences. ${ }^{125}$ As far as the Munich Consensus was concerned, moreover, the need for an independent Literature Academy went beyond the protection of individual writers' interests. Writing to Schäfer in January 1934 , Grimm quoted a letter from a young historian, whose identity remained undisclosed, but who had been a member of the NSDAP for several years. His letter was interpreted by Grimm as an appeal to those, like the Münchner, who sought not rank and position but to uphold the integrity of German literature: 'To maintain a priesthood of the arts or science in this age of mass propaganda and against the stampede of triumphant superficial education of elementary school teachers and NCOs is very difficult. It must be attempted, even if we perish in the attempt. ${ }^{126}$ The Literature Academy therefore had a role in protecting Germany from the evils of 'democracy', understood by the Munich Consensus as the influence of the masses rather than parliamentary institutions and political representation.

The paradox of a totalitarian, nationalist government whose dependence on the assent of the masses, however willingly or unwillingly given, led to the establishment of an all-pervasive propaganda apparatus presented

I23 Blunck, II. Hornung 1934, B.Arch. NS8 - IOI.

I24 Grimm to Blunck, 23.4.1935, B.Arch. R56V-I87.

I25 Binding to Grimm, 2.12.1934, DLA - A: Grimm, Binding to Grimm, 1933-1934.

I26 Grimm to Schäfer, 25.I.1934, DLA - A: Grimm, Grimm to Schäfer, I928-1950. 
certain dangers in the minds of the völkisch-nationalist writers. While they emphasised the Volk as the foundation of society, they did not believe in the self-determination of the people. Instead, they promoted a divinely ordained social structure to be determined and governed by an elite called to this task. As writers, the members of the Munich Consensus believed they belonged to this elite and were therefore not bound by the same authority that governed the masses. Instead, they stood outside and above the rest of society. They were the protectors of the spirit and integrity of the Volk, enshrined in German literature, in the face not only of the uneducated masses, but also of the propaganda measures needed to control them. While none of them denied the need for such measures, they sought to prevent the subordination of their own work to these ends.

While, to the rest of the Academy, the Münchner presented a united front based on a fundamental belief in their position in German society, among themselves the ban of Kolbenheyer's speech unleashed new doubts regarding the practical responsibility of the new Literature Academy for representing its members in the state. While they unanimously approved of the speech's message, they were divided over the appropriate response to the ban. Grimm was swift to voice his opinion that the Senate of the Academy should declare its support for Kolbenheyer; ${ }^{127}$ Münchhausen agreed. ${ }^{128}$ Schäfer, Strauß and Binding, on the other hand, adopted the opposite stance. Insisting that making the ban a formal matter for the Academy would be dangerous, Binding defined it as a local instance against which they were powerless. ${ }^{129}$ In contrast to Grimm, he viewed the ban as a minor discomfort of the völkisch revolution. Grimm, on the other hand, saw it as a more fundamental attack on the principles of the 'Munich Consensus', summing up his relationship with the revolution, which would remain consistent throughout the Third Reich: 'I am in favour of the Revoluton, but I am not one of those people who can take part passively,

I27 Grimm to Schäfer, II.2.1934, DLA - A: Grimm, Grimm to Schäfer, I928-I950.

I28 Grimm to Schäfer, 16.2.1934, DLA - A: Grimm, Grimm to Schäfer, 1928-1950. See also Grimm to Schäfer, 25.2.1934, DLA - A: Grimm, Grimm to Binding, 1933-1934. Binding to Grimm, I.3.1934, DLA - A: Grimm, Binding to Grimm, 1933-1934. 
but do so actively with pleasure. ${ }^{130}$ Typically for the history of the Academy in the Third Reich, while its members spent their energy discussing how to respond to the ban, in the end it was lifted before they reached any decisions. ${ }^{131}$ Nonetheless, the discussions themselves provide an example of the efforts of the Munich Consensus to define their role as the representatives of German writers and the manner in which they exchanged their ideas within the framework of the Academy.

As far as Kolbenheyer himself was concerned, the ban of his speech confirmed the negative manner in which he was viewed by the Nazi leadership $^{132}$ and was a sign of Nazi attitudes towards the völkisch-nationalist Academy concept, a connection that Kolbenheyer made in his post-war account of the period. ${ }^{133}$ After the Second World War, the ban of his lecture became a central element in his defence against accusations of collaboration with the Nazi regime. He presented himself as a fighter for intellectual freedom in an oppressive cultural environment. Alongside the large majority of 'geistig people', Kolbenheyer argued, he had been convinced that the Nazi Party was the only organisation that would be able to relieve the German Volk of its economic and political problems. At the same time, he argued that even in the first months of the 'revolutionary government' it was already clear that German intellectual life was threatened by the political radicalism of the government. This view was, he suggested, by no means limited to the writers and intellectuals who had been exiled during the Third Reich; the majority of German intellectuals were concerned for German intellectual life. The only exceptions were those who used the upheaval for personal gain.

Writing after 1945 , he therefore also used the ban as an opportunity to attack those writers who had fled the Nazis. The apparent domination

I30 Grimm to Binding, 4.3.1934, DLA - A: Grimm, Grimm to Binding, I933-I934. Emphasis in original.

I3I Ibid.

I32 Kolbenheyer referred to the suspicion with which he was viewed in government circles in a letter to Münchhausen, 26.2.1934, DLA - A: Grimm, Kolbenheyer to Grimm, 1918-1938.

I33 Kolbenheyer, Sebastian Karst, vol. III, pp. 177-178. 
of German intellectual life by that group during the I950s was a common grievance among völkisch-nationalists, who felt that they were victims both under the Nazis and in the post-war period. The difference between those who stayed behind and those who emigrated during the 1930s, Kolbenheyer argued, was that the latter had fled in fear for their personal safety and the profits they would be able to make for their work; the former, on the other hand, were concerned only for the wellbeing of the Volk. ${ }^{134}$

\section{The End of the Struggle for Institutional Recognition}

While the Munich Consensus asserted the autonomous nature of the Literature Academy, in practice it could not exist without some institutional backing. As part of the Prussian Academy of Arts, at the time of its Gleichschaltung it was clearly subordinate to Rust as Prussian Minister of Culture. The foundation of the RKK under Goebbels, however, complicated the situation. As 1934 dawned the Münchner became increasingly impatient for a decision that would resolve the Academy's lack of institutional definition, which was holding up the ratification of their constitution at the ministerial level and therefore also the start of what they hoped would be their real work. The continued lack of institutional security was therefore a constant theme in their communications in 1933 and 1934. In December 1933, Strauß asserted the authority of the Academy in this matter: 'We have a constitution, the Senate has accepted it, according to the power of our autonomy it is therefore binding for us - whether the curator has signed it or not - until it is repealed. ${ }^{135}$ Nonetheless, as Schäfer made clear to Grimm on 2oth December $1933,{ }^{136}$ without Rust's

134 Ibid., p. 178 .

I35 Strauß to Grimm, I0.12.1933, DLA - A: Grimm, Grimm to Binding, 1933-1934.

I36 Schäfer to Grimm, 20.12.1933, DLA - A: Grimm, Schäfer to Grimm, I91I-I935. Strauß's plan was to ensure that the Academy came under the direct jurisdiction of Hitler, rather than any specific ministry. 
formal ratification of the constitution, the Academy remained impotent, as the years that followed were to prove. In a letter to Münchhausen on 23rd April 1934, Schäfer added that the situation of völkisch writers in Germany was no better under the Nazis than it had been in the Weimar Republic. ${ }^{137}$

On I2th January 1934, Johst reported that Rust had agreed in theory to the foundation of an Academy of German Arts out of the three existing sections of the Prussian Academy of Arts. An official statement from the Minister on Kolbenheyer's draft constitution was expected soon. In the meantime, Johst instructed, the work of the Academy should continue as if the constitution were already in force. ${ }^{138} \mathrm{~A}$ letter from Rust of 16 th April 1934 to Binding also noted the impatience of the Munich Consensus for a quick solution to the problem of the Academy's situation. Placing the issue in the wider context of the changes occurring in the Reich as a whole, the socalled Reichsreform, Rust asked for patience and promised an answer within weeks. ${ }^{139}$ It nonetheless became increasingly evident that Kolbenheyer's constitution was not going to be ratified by Rust, for whom, as Schäfer noted to Grimm, the Academy was no longer useful in the fight for influence against Goebbels. The foundation of the RSK removed the need for the Academy:

They will place us on a stool in the corner, just as Johst already speaks of us six Münchener as a group of old-fashioned men hungry for recognition. It seems to me to be unworthy to hold off this decision any longer. Would it not be better if we issued a declaration, in which we explicitly expressed our personal readiness to serve the state, but to abandon this fiction of an academy, which is no longer even mocked by the people, only viewed with pity ${ }^{140}$

Schäfer therefore concluded: 'We don't fit into the system with our autonomy. The state can neither use nor develop us; it is adequately served by the R.Schr.Kr. [RSK].'.141

I37 Mittenzwei, Der Untergang einer Akademie, p. 345.

I38 Extracts from the Rundschreiben from Johst of I2.I.1934 were enclosed in a letter from Grimm to Binding of 23.4.1934, DLA - A: Grimm, Grimm to Binding, 1933-1934.

I39 Rust to Binding, 16.4.1934, DLA - A: Grimm, Binding to Grimm, 1933-1934.

I40 Schäfer to Grimm, 28.8.1934, DLA - A: Grimm, Schäfer to Grimm, I91I-I935.

I4I Ibid. 
Like Schäfer, Kolbenheyer's patience was also limited. In February 1934, he expressed his frustration, declaring that the Academy's position was untenable. In Johst, he argued, the Academy had a President who was 'a young writer whose achievements up to now can be taken, in the best case, as a sign of promise, but who possesses - as I see it more sense for adventure sports than for the literary arts. ${ }^{142}$ He therefore called for the question of leadership to be thrown open to the Senate. He also recognised the government's attempts to break down the networks of völkisch-nationalist writers in the Academy. Writing to Grimm on 26th April 1934, he asserted the need for unity in the Munich Consensus against the methods of Rust's ministry. ${ }^{143}$ By October 1934 his patience reached an end. Declaring his intention to withdraw from the constitutional committee and to resign his seat in the Senate, he protested against the Nazi authorities' continued neglect of the constitution. At the same time he also hoped to force a confidence vote on the Academy leadership, informing Grimm that he would on no account take part in any more meetings chaired by Johst. ${ }^{144}$ Following his resignation, ${ }^{145}$ his place in the Senate was nonetheless kept open for him by his colleagues, the majority of whom were members of the Munich Consensus and reluctant to see what influence they had in the Academy lessened by the departure of one of their number. ${ }^{146}$

As long as the Academy existed in an institutional no-man's-land between the increasingly redundant Prussian Ministry of Culture and Goebbels' Propaganda Ministry it would remain powerless. It appears

I42 Kolbenheyer to Schäfer, 24.2.1934, DLA - A: Grimm, Kolbenheyer to Grimm, I918-1938.

I43 Kolbenheyer to Grimm, 26.4.1934, DLA - A: Grimm, Kolbenheyer to Grimm, I918-1938.

I44 Kolbenheyer to Grimm, I2.10.1934, DLA - A: Grimm, Kolbenheyer to Grimm, I918-1938.

I45 Kolbenheyer to Münchner, I7.10.1934, DLA - A: Grimm, Kolbenheyer to Grimm, I918-1938.

I46 Grimm to Kolbenheyer, I6.I0.1934, DLA - A: Grimm, Grimm to Kolbenheyer, 1933-1959. 
that the question of situating it in the institutional landscape of the Third Reich was barely discussed by the government with its members. Instead the Academy became a pawn in the struggle between Goebbels, Rosenberg, Rust, and finally Göring for domination over the cultural sphere.

At the same time, the members of the Munich Consensus privately sought to arrive at their own solution. Their preferred option, although far from perfect, was to be placed directly under the authority of Hitler himself. Strauß formulated a plan to present the Academy's function as the 'Curator of the National Spirit' that he hoped would provide them with the key to Hitler's patronage. He was supported to this end by Schäfer, who wrote to Grimm on 27th February 1934: 'According to my "optimism" we would have been able to rescue our existence if we had found a key direct to $H$. with the plan of our curatorship. ${ }^{147}$ Grimm's response to the plan was neutral. If the Academy were placed directly under Hitler, he argued to Binding, it would actually end up subject to a delegate, who would be in a position to dictate the limits of their competencies and existence. Should they protest, they would not be protesting for the Academy, but against the Führer's delegate, making them 'in the best case irritating and odd, in the worst and more likely case however we then appear to be rebels, who must be removed. This is the danger we are facing. ${ }^{148}$ To Schäfer he also expressed his concern that the situation could quickly go seriously wrong if they did not clarify exactly what they meant by their autonomy. ${ }^{149}$

The other options, however, were still less appealing. Always the pessimist, Schäfer raised the dismal option of ending up under Rosenberg, writing to Grimm on 27 th February 1934:

I expect that it will be the Reichsstelle under which the Academy (not only our section) will be subordinated. What that means is only too clear to me [...]; we would be anything other than appointed 'by God's grace' under Staatssekretär R.; Asiatic,

I47 Schäfer to Grimm, 27.2.1934, DLA - A: Grimm, Schäfer to Grimm, I911-1935.

I48 Grimm to Binding, 4.3.1934, DLA - A: Grimm, Grimm to Binding, 1933-1934.

I49 Grimm to Schäfer, 25.2.1934, DLA - A: Grimm, Grimm to Binding, 1933-1934. 
Estonian air will blow away our German dreams. All we will have of the Academy will be that we are protected by our silence, in which all intellectuals will be included. ${ }^{150}$

This outcome would indeed have been welcomed by Rosenberg, who had enthusiastically promoted Johst, a long-standing member of the KfdK, as the president of the Literature Academy in the hope that through him he would be able to expand his own sphere of influence. Nonetheless, it does not appear to have been an option that was ever seriously considered by those in power. Likewise, the option of coming under the jurisdiction of Rudolf Hess, which was also briefly raised by Schäfer in the same letter, did not materialise as a serious possibility.

The Academy came close to being subordinated to Goebbels and the Propaganda Ministry, an outcome hinted at by Grimm on 27 th June I934 when writing to Binding to inform him that the fate of the Academy had appeared to be decided at a meeting with Rust the previous week. ${ }^{151}$ Contrary to the vision of an Academy that stood for German literature not as propaganda but as art, Grimm argued that placing it under Goebbels would be a clear sign of how little the Nazi government valued their literary endeavours. German literature was to serve the propaganda requirements of the Nazi Party, either as an endorsement of Nazism, or simply as entertainment designed to keep the population happy, a role that film and theatre were likewise expected to fulfil. The nation's leaders were not interested in the eternal truths the völkisch-nationalist writers claimed to preach, but in the benefits their works could bring to the National Socialist state. In the end, the question of the institutional place of the Academy was only settled in 1937, when Hermann Göring was appointed Protektor der Preußischen Akademie der Künste, by which time the Literature Section was functionally crippled.

The main effect of Göring's appointment was to bring to a head the tension that existed between Rust and Goebbels. It occurred at Rust's initiative. After he had been named Minister für Wissenschaft, Erziehung und Volksbildung in April 1934, Rust continued to defend his position as

I50 Schäfer to Grimm, 27.2.1934, DLA - A: Grimm, Schäfer to Grimm, I91I-1935.

I5I Grimm to Binding, 27.6.1934, DLA - A: Grimm, Grimm to Binding, I933-1934. 
curator of the Academy from Goebbels' ambitions. The fact that, since the establishment of the RSK, the Academy had been of little use to him as a weapon against Goebbels in the scramble for power and influence in the government meant that he lost interest in its concerns until 1937 when it seemed likely that it would fall into Goebbels' hands. To prevent this addition to Goebbels' propaganda empire, Rust arranged for it to be offered to Göring. ${ }^{152}$ Goebbels' enraged diary entries promised that Hitler would intervene to dismiss Rust and force Göring to dissolve the Academy. ${ }^{153}$ Hitler delayed his decision, however, providing Göring with an opportunity to initiate the 'cleansing' of the Sections for Fine Arts and Music.

The Literature Academy remained largely unchanged by these measures, unlike the other two sections of the Prussian Academy of Arts, which had not gone through the same thorough Gleichschaltung process in 1933. Göring's appointment provoked little reaction from the Munich Consensus, whose hopes for the Academy had by now diminished to nothing: Grimm was more concerned with his private initiatives, Kolbenheyer had given up work on his constitution, the Academy no longer featured in Schäfer's letters to his colleagues. ${ }^{154}$ Instead the Literature Academy was more severely affected by the death of Binding in August 1938, which left it without a Vice-President in Berlin and the Munich Consensus with one fewer influential member. Neither was able to replace him before the outbreak of the Second World War, which served only to formalise the inactivity. Not vital to the war effort, the government and the Academy's members themselves now formally accepted what was already fact; the question of the status and function of the Academy was postponed until the war was over. ${ }^{155}$

I52 Mittenzwei, Der Untergang einer Akademie, pp. $385-387$

I53 Fröhlich (ed.), Die Tagebücher von Joseph Goebbels, part I, vol. 3: 16.7.1937, pp. 203-204; 29.7.1937, p. 216; 4.8.1937, pp. 224-225; 5.8.1937, p. 226; 7.8.1937, p. 229; 10.8.1937, p. 231; 11.8.1937, p. 232; 13.8.1937, p. 234.

154 Mittenzwei, Der Untergang einer Akademie, p. 394.

I5s Ibid., pp. 408-409, 440-44I. 


\section{Inner Emigration}

The disengagement of the Münchner from the immediate concerns of the Academy was not caused by its subordination to Göring, but was evident long before 1937. By the end of 1934, not yet two years after the reconstitution of the Literature Academy, a changed attitude among the members of the Munich Consensus was already discernable. Reflecting to an extent the tendencies of so-called 'inner emigration' among writers and intellectuals in the Third Reich, they became less concerned with the immediate communication of their values to the Volk. Instead they put their energy into becoming the guardians of those values for the future. They began to retreat from direct ideological engagement with the regime in favour of a concentration on activities based in the private sphere, postponing action in order finally to bring about the völkisch-nationalist revolution when the climate became friendlier.

On 28th October 1934, Schäfer declared that, while there could still be no talk of a real German Academy of Literature, to resign would only play into the hands of those who wanted to get rid of them. Institutionally, he suggested, they were strongest as a section of the Prussian Academy of Arts, where they were protected by Rust. He also suggested that Prussia's power was growing in the Reich, and therefore counselled against distancing themselves from this last power base. Instead they should use their position in the Prussian Academy of Arts to achieve as much as possible. Outwardly therefore, they should accept their weak position. Among themselves, however, Schäfer proposed they form an Academy consisting of the six Münchner and Beumelburg, with the addition of Stehr and perhaps also Hauptmann. Johst and Blunck would not be included. Schäfer's suggestion was radical. Finding themselves unable to fit their ideological beliefs into the institutional framework of the state, they should reject formal institutional definition: 'As this Academy we will do absolutely nothing externally. Internally, however, we will prepare ourselves for the true task. ${ }^{156}$

I56 Schäfer to Grimm, 28.10.1934, DLA - A: Grimm, Schäfer to Grimm, I91 I-I935. 
This true task he outlined borrowing the words of Paul Ernst: 'We must know that the first step to higher humanity is that we mercilessly fight against our spiritual cowardliness. ${ }^{157}$ Their association would therefore be based on the shared understanding of the purpose of German writers and the need to preserve the German spirit for the future. To this end, he asserted the importance of regular contact between the group, suggesting that they meet every quarter in the Academy in Berlin. ${ }^{158}$

Kolbenheyer likewise wrote to Grimm on 2nd May 1935, announcing that as he had laid down his seat as a Senator of the Academy, he no longer considered himself a member of the Munich Consensus, which, he argued, had been formed for the Academy. He expressed his overall concern about the state of German literature: 'Gradually I am beginning to worry about our art. We, who have maintained standards and promoted many literary trends, appear to receive only every possible proof of contempt and our complete superfluity. ${ }^{159}$ In responding four days later Grimm encouraged Kolbenheyer to maintain his co-operation with the Munich Consensus. He made it clear that the Munich Consensus had a task that went beyond the Academy, adding his voice to that of Schäfer the previous October:

The Munich circle absolutely must outlive the Academy. A chance for collective action of those truly called must remain. I therefore ask that you withdraw your declaration that you no longer belong to the circle. If your predictions come to pass, I would anyway like to suggest that we six resign. I would like to suggest further that we create some sort of fraternity out of about fifteen men, who would then have more weight than the Senate due to the names that belong to it. The fraternity should be no more than a friendly union. ${ }^{160}$

By 1935, therefore, the Munich Consensus had developed beyond the context of the Academy. Its members were not bound to each other through their

I57 Ibid.

I5 8 Ibid.

I59 Kolbenheyer to Grimm, 2.5.1935, DLA - A: Grimm, Kolbenheyer to Grimm, I918-1938.

I60 Grimm to Kolbenheyer, 6.5.1935, DLA - A: Grimm, Grimm to Kolbenheyer, 1933-1959. 
institutional allegiances, but because they represented 'German literature'. Acting as commentators within the system they placed themselves above the narrow world of government politics, working solely for the cause of the German Geist.

Meanwhile, the Academy had almost completely stagnated. One or two dying gasps were evident among its membership, but none amounted to anything other than a reassertion of its incapacity. In response to a letter from Rust, in which the Minister lamented the lack of activity in the Academy, Binding proposed to Grimm that the two of them cooperate on two lectures, to be delivered on consecutive days in early 1936. These were intended to improve the public perception of the Academy and to increase understanding of its purpose in the RSK and the Propaganda Ministry. The first, 'Vom Recht der Dichtung,, would be presented by Binding and deal factually with the fundamental elements of an Academy. The second, 'Vom nordischen Wesen und der nordischen Berufung,' would be given by Grimm, presenting the importance of German literature in an international context. Binding further suggested that they work with Johst on this project; the Academy's President, he argued, would not fail to recognise its importance. It is likely that he wanted to create an opportunity to make the Münchner view of the Academy and its raison d'etre clear to the President and to force his engagement for their purposes. ${ }^{161}$

Grimm's response to Binding was unenthusiastic. He suggested that the Academy would never find favour in the leading offices of the Reich because it could never be active in the way they wanted. As the Third Reich progressed, the völkisch-nationalist writers in the Academy increasingly understood their task in broad terms of representing and protecting German literature, and thereby the German Geist, for future generations. The fact that the Prussian Academy of Arts, in which the Literature Academy still had its home, had already existed for 200 years made this long-term perspective historically justifiable. Grimm therefore told Binding that he recognised the general necessity of which the he spoke, but did not feel that the necessity was immediately applicable. More 
personally Grimm also declared that he could not consider undertaking the lectures as he needed to concentrate on writing his next book. ${ }^{162}$ Finally he suggested that his appearance on behalf of the Academy would not necessarily find a positive reaction in the government, a reference to his already controversial position with Goebbels in particular. Having been relieved of his position on the Präsidialrat of the RSK on the occasion of his sixtieth birthday on 22nd March 1935, ostensibly due to his age, but in fact the result his uncompromising and critical attitude to the RSK and the government, Grimm's relationship with Goebbels did not improve in the years to come.

Grimm's disenchantment continued into 1936. On I4th March of that year he received a letter from the Academy requesting him to sign yet another declaration, this time a public assurance of the loyalty of German writers to the Fübrer, to be published in conjunction with the Reichstag elections of 29 th March: 'In this historical hour it is the self-evident duty of the German writer to pledge himself without reservation to Adolf Hitler. The 29th March will prove to the world that intellectual Germany stands unflinchingly for the Führer, the Volk and the Party. ${ }^{\text {'63 }}$ Grimm's response was in many ways more extreme than might have been expected. Not least, he felt the declaration was a mistake from the point of view of foreign policy. Furthermore, while he declared himself prepared to publicly support Hitler in any action opposing the Versailles Treaty, he went on:

With regard to the Party, I cannot declare that I stand unflinchingly for the Party. I don't belong to the Party. I wish that National Socialism should be achieved by a Volk united in mind and conscience. I am therefore unable to comprehend a distinction between Party members and other Germans. I also think that an avowal by the Academy to the Party would be inappropriate. The Literature Academy would thereby end up in the wrong place, namely in the avowed service of propaganda, and would lose the power to gain support for Germany, which it now has in spite of its latency. ${ }^{164}$

I62 Grimm to Binding, 22.II.1935, DLA - A: Grimm, Grimm to Binding, I935.

I63 Quoted by Grimm in a letter to the 'Schriftführer der Akademie der Dichtung' (Beumelburg) on I5(?).3.1936, DLA - A: Grimm, Grimm to Akademie, 1936.

164 Ibid. 
The attitude Grimm expressed in this letter was not new. What was new was such a clear and open expression of his scepticism regarding the Nazi Party. His willingness to oppose it openly was not, however, necessarily a sign of courage, or of clear-sightedness regarding the dangers the Party posed for Germany. Grimm's view point was firmly embedded in his belief that he, and the other Münchner, constituted an elite that was not answerable to the government, but to the German Volk. As such he claimed a right to speak out in opposition to the regime.

Grimm had sought to institutionalise this position in the Literature Academy. His discovery that his name had been added to the declaration in spite of his refusal to sign it led him to consider resignation from the Academy. In a conversation with Binding, he learned that the project had been the work of Beumelburg and Johst, with the cooperation of Hinkel of the RSK, who had no formal relationship with the Academy. This represented the direct involvement of the RSK in the internal affairs of the Academy, a further sign to Grimm of its weakness. As a result, Grimm informed his Munich colleagues of his intention to resign. ${ }^{165}$ Both Binding and Schäfer recommended restraint. ${ }^{166}$ Schäfer also expressed surprise at seeing his own name included among those endorsing the declaration in the newspapers. Nonetheless, his letter to Grimm suggests confusion and bewilderment rather than anger. ${ }^{167}$

Grimm did not resign, but by the middle of 1936 the Munich Consensus had largely run out of ideas and energy. The question of the institutional home of the Academy remained unresolved, and its constitution unratified. Thus the politicians were victorious over the writers. Grimm's protest had little impact. ${ }^{168}$ While he did not resign, he refused to attend any

I65 Grimm to Munich Consensus, 3.4.1936, DLA - A: Grimm, Grimm to Akademie, 1936; also in Grimm to Binding, 1936-1937.

166 Binding to Grimm, 26.3.1936, DLA - A: Grimm, Binding to Grimm, 1935-1936.

I67 Schäfer to Grimm, 6.4.1936, DLA - A: Grimm, Schäfer to Grimm, 1936-1948.

I68 He also protested against the failure of his colleagues to support a proposed Academy declaration drafted by Kolbenheyer and himself. For the lengthy and inconclusive discussions on this declaration see: Kolbenheyer and Grimm, draft declaration of the Senate of the German Literature Academy, enclosed with Grimm to Binding, 
more meetings of the Academy while Johst and Beumelburg remained in office. ${ }^{169}$ By the end of 1936 , his Munich colleagues were equally dispirited and increasingly their interest turned from the Academy to other matters.

\section{Conclusion}

The Munich Consensus should not be dismissed as a failure out of hand. It presented the Nazi government with a problem. Having already lost many prominent writers to exile, to exclude men like Grimm, Kolbenheyer, Binding, Schäfer, Strauß and Münchhausen would have been to exclude a significant proportion of the most prominent writers remaining in Germany. For German readers, moreover, their ideology, in so far as it was expressed in their writing, was indistinguishable from National Socialism. Therefore, as long as there was no one else to replace them, they were safe in the Academy. At the same time, by allowing the Academy to exist with the constant promise of further development, but never allowing that development to happen, the Nazis successfully contained the dissenting voices of these writers.

23.5.1935, DLA - A: Grimm, Grimm to Binding, 1935; Grimm to Munich Consensus, 23.5.1935, DLA - A: Grimm, Grimm to Academy, 1935; Kolbenheyer to Grimm, 7.5.1935, DLA - A: Grimm, Kolbenheyer to Grimm, 1918-1938; Binding to Grimm, 27.5.1935, DLA - A: Grimm, Binding to Grimm 1935-1936; Strauß to Grimm, 28.5.1935, DLA - A: Grimm, Strauß to Grimm, 1933-1956; Grimm to Binding, 29.5.1935, DLA - A: Grimm, Grimm to Binding, I935; Schäfer to Grimm, 3.5.1935, DLA - A: Grimm, Schäfer to Grimm, I911-1935; Grimm to Schäfer, 6.5.1935, DLA - A: Grimm, Grimm to Schäfer, 1928-1950; Schäfer to Grimm, 26.5.1935, DLA - A: Grimm, Schäfer to Grimm, I9II-1935; Grimm to Beumelburg, 6.7.1935, DLA - A: Grimm, Grimm to Academy, 1935; Grimm to Binding, 11.7.1935, DLA - A: Grimm, Grimm to Binding, 1935; Grimm to Beumelburg, 19.9.1935, DLA - A: Grimm, Grimm to Academy, 1935.

169 Grimm to Binding, 9.4.1937, DLA - A: Grimm, Grimm to Binding, 1936-1937. 
In many ways the Munich Consensus became an Academy within the Academy. Only through their unofficial association did they make any progress towards achieving the independent and autonomous body they hoped to build. Without any real power in their struggle against the lack of interest in the Academy among Nazi politicians, their shared frustrations did much to cement their cooperation. In the end they were unable to carry out their plans for German literature without recognition from the government, but they did succeed in keeping an independent network alive, providing its members with a basis from which they sought other ways to achieve their goals. For this reason, it is not in the end appropriate to describe them as following a course of inner emigration. The Munich Consensus did not altogether remove itself from the political playing field. Their völkisch-nationalist creed made them feel responsible for the German Volk and demanded action from them. Their extra-academic activities will be examined in the following chapter. 



\section{Beyond the Literature Academy}

The völkisch-nationalist writers examined in this book defended the independence of 'German' writers, and sought to protect the German Geist from the tyranny of party politics. A self-professed elite, they viewed their role in German society as a calling. This determined their attitude towards the German Literature Academy. It also directed their actions in other spheres. Despite initial support for the regime, the significant group of völkischnationalist writers considered in the previous chapter demonstrated that they were not primarily concerned with winning Nazi favour or endorsing National Socialism for its own sake. A longer tradition of nationalist writing and thought provided them with an agenda in the Third Reich.

The German Literature Academy provided one focus for the energies of some of the most prominent völkisch-nationalist writers in the first years of the Third Reich. It was, however, not the only arena in which they sought to achieve their goals in the 1930s. While the production of original new work was relatively low they remained extremely active, as Ernst von Salomon pointed out in Der Fragebogen. ${ }^{1}$ Right-wing literary networks were more fluid than the history of the Literature Academy alone suggests. Add their frequent correspondence to regular meetings at literary events and a picture emerges of a more dynamic literary sphere during the Third Reich than the institutional history might at first suggest.

These writers also found ways to communicate their own vision and their dissatisfaction with the Nazi regime to a wider public. Völkisch ideology

I Ernst von Salomon, Der Fragebogen (Hamburg: Rowohlt, I95I; edition consulted 1993), pp. 189-190. See also Dietrich Strothmann, Nationalsozialistische Literaturpolitik: Ein Beitrag zur Publistik im Dritten Reich (2nd edn, Bonn: Bouvier, I963), p. 91. 
emphasised the importance of deeds over words, encouraging writers to reach beyond their immediate circles. Two ways in which they achieved this in the Third Reich, the journal Das innere Reich and Hans Grimm's Lippoldsberger Dichtertreffen, are examined in this chapter. Attention will also be given to the history of the Langen-Müller Verlag, one of the most prominent völkisch-nationalist publishing houses in Germany in the 1930s, and publisher of Das innere Reich. The struggle of its director, Gustav Pezold, and several authors, including Grimm, Schäfer, Kolbenheyer and Strauß, to maintain its independence in the face of the Nazi Party's own publishing house, the Eher Verlag, ended in failure. Nonetheless, it strengthened the ties between völkisch-nationalist intellectuals and demonstrated the extent to which some were willing to stand against the government, providing several with alibis for the post-war period.

\section{Das innere Reich}

Nazi literary censorship made inroads into journalistic and academic literary criticism. Nonetheless, in spite of increasingly stringent attempts to establish an all-encompassing system of literary control, between 1933 and 1936 it was unclear to many critics what constituted Nazi literature. In addition to a lack of public enthusiasm for many works that were branded 'National Socialist', many literary journals run or endorsed by the Party press organisations produced conflicting reviews of the same works. ${ }^{2}$ This undermined the Party's claim to represent a unified and clear ideological structure. Goebbels prohibited artistic criticism altogether in 1936, a result of increasing complaints about the state of art and literary criticism, both from inside and outside the Nazi Party. It was replaced by 'National Socialist A History of German Literary Criticism, I730-1980 (Lincoln: University of Nebraska Press, 1988), p. 368. 
contemplation of art,' executed by officially authorised commentators over the age of thirty, thus ensuring a mature approach. ${ }^{3}$ It was pointed out that 'criticism' should now be unnecessary given that all published works had to be approved by the Party machinery. Organs that were caught breaching Party guidelines were subject to strict warnings. ${ }^{4}$ The tight controls imposed on the art review process were intended to ensure that the internal tensions and conflicting ideological interpretations within the Nazi Party did not make themselves apparent to the general public. ${ }^{5}$

Literary criticism was also affected by the nature of the books that were published: as controls over publishing tightened, the scope of available new literature became narrower. By the time Hanns Johst became president of the RSK on 3rd October 1935 the positions in the administration of literary life had been filled laregly by followers of the Nazi Party. In theory only works that made it past the Party's censorship machinery were made available to the public; the fact that they had been declared suitable for publication by the Nazi Party made them immune to outside criticism. Increasingly, criticism of published literature came to equal criticism of the Nazi Party itself. ${ }^{6}$

The foundation of the new cultural journal Das innere Reich in 1934 was among the most significant developments in the völkisch-nationalist literary landscape following the Nazi Machtergreifung. Gustav Pezold first conceived the idea of establishing a conservative journal in the LangenMüller Verlag in 1932. ${ }^{7}$ Its editors, Paul Alverdes and Benno von Mechow, were selected in that year. The title, suggested by von Mechow, was also decided before the Nazis came to power. ${ }^{8}$ Like the members of the Munich Consensus, with several of whom they were in close contact, Alverdes and

3 Ibid., p. 369 .

4 See, for example, note on the Kulturpolitische Pressekonferenz, B.Arch.R56V-48.

5 Zimmermann, 'Literary Criticism', p. 370; see also Joseph Goebbels' diary entry for 29th November 1929 in Fröhlich (ed.), Die Tagebücher von Joseph Goebbels, part I, vol. 2, p. 739.

6 Zimmermann 'Literary Criticism', p. 36r.

7 Lokatis, Die Hanseatische Verlagsanstalt, p. 103.

8 Mallmann, 'Das innere Reich', p. 48. 
von Mechow greeted the Third Reich with enthusiasm. Like the Munich Consensus, however, their relationship with the regime deteriorated and after 1945 they and their colleagues took pains to emphasise their opposition to the Nazis. ${ }^{9}$

Curt Hohoff, who was a member of the journal's staff from 1935, later praised it as an 'attempt at an intelligent journal in an anti-intellectual regime. ${ }^{30}$ In his romanticised memoirs of his youth in Munich in the $1930 \mathrm{~s}$ he described his arrival in Munich as a student in $1934 .{ }^{11}$ His mother had dispatched him with an introduction to Hans Severing, the proprietor of a bookshop in the Maximilianstraße. Hohoff described the shop as a place for serious literature, the presence of Langen-Müller publications, including Das innere Reich, alongside those of Insel, Rowohlt, S. Fischer, the Deutsche Verlagsanstalt and the Hanseatische Verlagsanstalt, confirming this fact. ${ }^{12}$ Subsequent attempts to place Das innere Reich in the cultural and political landscape of the Third Reich have not, however, resulted in a clear picture of its position. While Harry Pross placed it alongside the Hitler Youth organ, Wille und Macht, as an organ of the regime, ${ }^{13}$ Klaus Günther described it as a well-meaning, but feeble compromise by authors who were concerned to reconcile their cultural and intellectual concerns under the repressive rule of the fascist state. ${ }^{14}$ Hans Mayer, on the other hand, saw it as a secret gathering point for writers against the regime. ${ }^{15}$ Ernst Loewy and Horst Denkler have also added their voices to the debate, both attempting to reconcile the conflicting interpretations of the journal p. I9 quoted in Mallmann, Das Innere Reich, p. 3.

Io Quoted in Denkler, 'Janusköpfig', p. 382.

II Curt Hohoff, Unter den Fischen: Erinnerungen an Männer, Mädchen und Bücher, 1934-1939 (Wiesbaden \& München: Limes Verlag, 1982)

I2 Ibid., pp. I3-I5

I3 Harry Pross, Literatur und Politik: Geschichte und Programme der politisch-literarischen Zeitschriften im deutschen Sprachgebiet seit I 870 (Freiburg im Breisgau: Walter, 1963), p. 125 .

I4 Denkler, 'Janusköpfig,' p. 382.

I5 Ibid. p. 382 . 
in literary historiography. ${ }^{16}$ Loewy describes it as 'more representative of the "conservative" than the radical forces within German literature in the Reich. ${ }^{17}$ On the other hand, he continues: 'Admittedly, there were also no signs of opposition to the Third Reich in it; forced into line like all the remaining journals, it represented the spirit of the time to a "more demanding" public. ${ }^{18}$

The journal catered for educated Germans who found the banal aspects of National Socialism unattractive. It reflected, in particular, the position of völkisch-nationalist literature in the Third Reich. The creators of the latter understood themselves as responding to a higher intellectual calling, beyond that of the mass National Socialist movement. Both Alverdes and von Mechow moved in the völkisch-nationalist literary circles in the I930s. They shared common bonds forged not only by their journal, published by one of the last independent völkisch-nationalist publishing houses, but also by wartime experiences and associations and their contacts with Grimm, Binding and others. They understood their cultural role in terms similar to those presented by the Munich Consensus. Indeed, not only is there considerable evidence that members of the Munich Consensus regularly read the journal, but they also formed a significant section of its core contributors. ${ }^{19}$

By aligning Das innere Reiche with the Munich Consensus, it is also possible to address the attempts of those who sought to defend the journal after I945 as an organ of inner emigration. The previous chapter demonstrated that while the Munich Consensus displayed some of the symptoms of inner emigration, the völkisch ideology that motivated its members also demanded

Loewy, Literatur unterm Hakenkreuz, p. 331; Denkler, 'Janusköpfig,' pp. 382-405

Loewy, Literatur unterm Hakenkreuz, p. 33I.

Ibid. p. 33 I.

See for example: Binding to Grimm, 4.3.1936, DLA - A: Grimm, Binding to Grimm, 1935-1936; Binding to Grimm, 6.3.1936, DLA - A Grimm, Binding to Grimm, 1935-1936; Binding to Grimm, 6.4.1937, DLA: Nachlaß Grimm, Binding to Grimm, 1937-1938; Schäfer to Grimm, 16.9.1934, DLA - A: Grimm, Schäfer to Grimm, I911-1935; Schäfer to Grimm, 26.5.1938, DLA - A: Grimm, Schäfer to Grimm, 1936-1948; Grimm to Strauß. 23.2.1938, DLA - A: Grimm, Grimm to Strauß, 1933-1956. 
that they take active responsibility for promoting their goals in Germany. Therefore, while they increasingly withdrew from direct engagement in politics, they were unable to retreat altogether. Instead they sought other outlets to achieve their aims. Das innere Reich thus became an organ of a more traditional form of völkisch thought than National Socialism. It should be viewed in the context of the activities of völkisch-nationalist writers, who were increasingly disillusioned by the Nazi regime, but rarely in direct opposition to it. They focused increasingly on the preservation and cultivation of the German Geist for the future. Instead of engaging directly in the politics of the present the journal became part of this longer struggle.

The second significant völkisch-nationalist element that characterised Das innere Reich was the experience of the First World War and Germany's defeat in 1918. This is recognised by Denkler, who identifies the War as the underlying factor in the self-definition of the journal. ${ }^{20}$ The War certainly influenced its two editors, both of whom drew on their experiences in the trenches in their own work, and it also provided the prime source of inspiration for many of its contributors. ${ }^{21}$ However, though the unifying element in the journal was not to be found in its reaction to the Nazi regime, but in its reaction to the First World War, this cannot be separated from adherence to the völkisch-nationalist vision of a new Germany. Introducing the first edition of Das innere Reich, Alverdes and von Mechow made it clear that for them the First World War represented the beginning of the national

20 Denkler, 'Janusköpfig,' pp. 386.

21 Paul Alverdes, Die Nördlichen (Berlin: Weiße Ritter Verlag, 1922); Die Pfeiferstube (Frankfurt am Main: Rütten \& Loening, 1929); Reinhold oder die Verwandelten (Munich: Langen-Müller, 193I); Die Freiwilligen (Munich: Langen-Müller, 1934); Das Winterlager (Munich: Langen-Müller, 1935); Eine Infanterie Division bricht durch (Munich: Langen-Müller, 1943). For a summary of Alverdes' career see: Sarkowicz \& Mentzer, Literatur in Nazi-Deutschland, pp. 69-70; Ingeborg Schuldt-Britting, SanktAnna-Platz Io: Erinnerungen an Georg Britting und seinen Münchener Freundeskreis (Munich: Buchendorfer, 1999), pp. 182-184. Karl Benno von Mechow's work reflected his background as a farmer, as well as his wartime experiences. For example: Das ländliche Jahr (Munich: Langen-Müller, 1930); Vorsommer (München: LangenMüller, 1934); Leben und Zeit aus dem Land Österreich: ein Erinnerungsbuch (Freiburg im Breisgau: Herder, 1938). 
revolution, which, after the struggle of the Weimar years, would finally end in victory for the National Socialist regime. ${ }^{22}$ The Nazis were, therefore, important to the extent they contributed to bringing about the Germany for which völkisch-nationalist writers had been fighting for decades.

True to its völkisch-nationalist pedigree, moreover, the journal also picked up on the themes that had occupied völkisch-nationalists throughout the Weimar Republic, defining itself against liberalism and republicanism and championing the most prominent völkisch-nationalist writers of the period. In the same edition, Alverdes addressed these issues in an article on new books, concentrating in particular on Grimm's Lüderitzland, ${ }^{23}$ which he praised for its sparse but expressive language and masterful narrative that described the simple, innocent person, the small man, the man on the street. ${ }^{24}$ In approaching Grimm's work more generally, Alverdes described the lack of appreciation it had found among republican literary figures before 1933 , adding that the reviews in his new journal would seek to right the mistakes of the past. He asserted Grimm's place among the modern Dichter, his writing reflecting his faith in the völkisch-nationalist themes he addressed. ${ }^{25}$ Alverdes' understanding of Dichtung transcended its political usefulness. For him, as for other völkisch-nationalists, Dichtung was identifiable in its representation of the fundamental nature of the Volk from which it came. ${ }^{26}$ At pains to avoid defining it as an organ of artistic criticism in the face of increasing restrictions in this sphere from Goebbels, the editors of Das innere Reich presented it in the role of commentator. Their reluctance to issue any more formal programmatic statements for the journal, Denkler suggests, reflected the concern of Alverdes and von Mechow to mask their own ambivalent feelings towards the regime. ${ }^{27}$

Paul Alverdes and Karl Benno von Mechow, Editorial to first issue of Das innere Reich (I. Jahrgang, I. Halbjahresband 1934), pp. I-4.

23 Grimm, Lüderitzland: Sieben Begebenheiten (Munich: Langen-Müller, 1934).

24 Paul Alverdes 'Zu neuen Büchern', Inneres Reich (Jahrgang, I. I. Halbjahr), pp. 4064I5, quotation, p. 4I2.

25 Ibid. p. 4I2.

26 Paul Alverdes 'Zu neuen Büchern', Inneres Reich (Jahrgang, I. I. Halbjahr), p. 408.

Denkler, 'Janusköpfig', p. 385. 
Alongside its editors, a wide variety of authors contributed to the journal. Most of them represented conservative or völkisch-nationalist thinking, but their attitudes towards National Socialism and the Nazi regime varied. ${ }^{28}$ In 1971, Alverdes asserted that the main concern of the editors was the quality of the writing, regardless of the political stance of contributors. The only outside pressure to which the editors responded, he claimed, was that of the LMV to publish house authors like Blunck, Schäfer and Kolbenheyer. ${ }^{29}$ While Alverdes' memory was undoubtedly selective after 1945, and his eagerness to present his activities during the Third Reich in an innocent light probably caused him to downplay the degree to which the journal courted the favour of the regime, the majority of contributors were nonetheless brought to the journal through the networks of völkisch-nationalist writers. The result was a wide variety of literary forms in its pages, including dramas and radio-plays, novels and poetry, as well as academic essays and a review section that discussed books, exhibitions and cultural events. Thematically, the journal presented political commentaries alongside fiction and artistic and literary reviews. Overall, the impression it gives is one of commentary on German life, reflecting the intrinsic and inseparable relationship of politics, culture and art in the völkisch ideology.

Rudolf Binding played an important role in the formation of the opinions of both Alverdes and von Mechow, and contributed significantly to the creation of a close network of völkisch-nationalist writers based in Munich that had a significant influence on the nature of Das innere Reich. Following his divorce and subsequent move to a house on the Starnberger See outside Munich in 1935, he gathered around him a group of writers residing in the area. After 1945 they became known as the Starnberger Kreis, which in its embryonic years included Binding, Alverdes and von Mechow, as well as the expressionist Georg Britting, Ludwig Friedrich Barthel, Heinrich Zillich pp. 78-86.

29 Letter from Paul Alverdes to Marian Mallmann, 31.5.1971, quoted by Mallmann in Das Innere Reich, p. 7I. 
and Edwin Erich Dwinger. Gatherings frequently began with a meal in the late morning and went on into the night, the literary guests congregating to enjoy Binding's hospitality and conversation. ${ }^{30}$ Among them Barthel, Dwinger and Zillich all upheld the ideals of National Socialism, both generally and in the pages of Das innere Reich, while others adopted a more ambiguous stance towards the regime. ${ }^{31}$ Binding himself was frequently described by his friends and in the press at this time as tall, slender and of knightly character as befitted a former cavalry officer. Like his younger guests, his writing career, which had begun with a collection of legends in 1909, when he was 40, was strongly influenced by his experiences in the First World War. ${ }^{32}$ During the Weimar Republic works of poetry and novellas followed, as well as an autobiographical work, Erlebtes Leben, first published in $1928 .{ }^{33}$ In the Third Reich he continued to publish, although less prolifically, up to his death in $1938 .{ }^{34}$

Binding also brought other writers to the journal, including Hans Grimm, whose annual Lippoldsberger Dichtertreffen, attended over the years by a large group of nationalist writers, served further to unite völkischnationalist writers independently of Party events. Among those who attended Grimm's meetings, alongside Binding and Alverdes, Joachim von der Goltz, Hermann Claudius, Erwin Guido Kolbenheyer, Werner Beumelburg, Friedrich Bischoff and Rudolf Alexander Schröder all contributed at some stage to Das innere Reich. Further contributors to the journal included Agnes Miegel, Wilhelm Schäfer and, posthumously, Paul

30 Binding to Wiechert, 26.2.1936 in Ludwig Friedrich Barthel (ed.), Rudolf G. Binding: Die Briefe (Hamburg: Dulk, 1957), p. 315; Binding to Barthel, 6.4.1937 in Barthel (ed.), RudolfG. Binding, p. 353; Binding to Barthel, 26.9.1937 in Barthel (ed.), Rudolf G. Binding, p. 378; Binding to Alverdes, 24.I1.1937 in Barthel (ed.), Rudolf G. Binding, p. 390; Schuldt-Britting, Sankt-Anna-Platz 10, pp. I87-188.

3I Mallmann, Das Innere Reich, p. 75 .

32 Schuldt-Britting, Sankt-Anna-Platz Io, pp. 78-79.

33 Rudolf G. Binding, Erlebtes Leben (Frankfurt am Main: Rütten \& Loening, 1928).

34 As well as numerous volumes of poetry, short stories and legends, after 191 8 Binding was also influenced by the theme of war, for example in works like: Aus dem Kriege (Frankfurt a/M: Rütten \& Loening, 1925); Deutsche Jugend vor den Toten des Krieges (Frankfurt a/M: Rütten \& Loening, 1933). 
Ernst. The latter, who was highly rated by the editors, had originally been a social-democrat. From the mid-1890s, however, his short novels and dramas dealt with the theme of duty, Heimat and loyalty to a Führer. His death in 1933 enabled both the editors and the Nazis to interpret his works according to their own ends, without any opposition from their creator. ${ }^{35}$

In the early years of the journal, some writers also appeared in its pages who later voiced opposition to the regime. Ernst Wiechert is among the best known among them. His work was not at odds with the Nazi ideology, but he openly protested against the Nazis and stood up for Martin Niemöller and Eduard Spranger during their incarceration in concentration camps. He later wrote about his own experiences as a prisoner in Buchenwald in Der Totenwald. ${ }^{36}$ As evidence of the journal's non-Nazi stance, after the Second World War, Hohoff also cited numerous bans on the journal, including one in 1943, which allegedly brought its production to an end. In fact this did not occur and the journal was finally closed down by the LMV itself following its October number in 1944. Moreover, while the journal did conflict with several Nazi organs in its early years, during its lifetime it was only banned once. ${ }^{37}$

In August 1936 an article by Rudolf Thiel was published to mark the I5oth anniversary of the death of Frederick the Great. ${ }^{38}$ It began: 'He is the most questionable figure in our history. It has come so far that we no longer really know why he is called "Great", the article went on to question the idealisation of the Prussian king in Nazi Germany. Greatness, according to Thiel's thesis, did not rest on personal characteristics. Instead, Frederick's greatness lay in his belonging and service to his Volk, and his Machiavellian ability to recognise the different and sometimes conflicting moral demands made by his private and public lives. His greatness therefore

36 Ernst Wiechert, Der Totenwald (Berlin: Aufbau Verlag, 1946). Mallmann discusses a range of further examples in Mallmann, Das Innere Reich, pp. 86-92.

37

38 Rudolf Thiel, 'Friedrich der Große: Charakterstudien zu einer Biographie. Zur 150. Wiederkehr seines Todestages am 17. August', Das innere Reich, 1936, Year 3, vol. 2, pp. 543-573. 
lay in the cultivation of his personal nature, whilst carrying out the tasks required to rule Prussia, to which he was born. He represented the ultimate synthesis of the individual with the Volk. Only in subordination to the Volk could the individual achieve his or her fullest potential, the völkisch identity being the foremost characteristic of every human being. ${ }^{39}$

Adverse reaction to this essay was delayed until 8th October 1936 when an article appeared in the SS journal, Das schwarze Korps, entitled 'Und das nennt sich "Inneres Reich"'. The following day Goebbels ordered a ban on Das innere Reich, which appeared in the press on IIth October. Alverdes, who was in Berlin for a meeting of writers who had been at the front during the First World War, was ordered to an interview with Goebbels. ${ }^{40}$ According to the Schriftleitergesetz of 1933 , in such cases not only the author, but also the editor and even the director of the publishing house were responsible. The ban therefore threatened Alverdes and Pezold with arrest by the Gestapo. The author Thiel suffered nothing, being not only a member of the NSDAP, but also an 'alter Kämpfer'. Von Mechow also remained unaffected, largely due to the mental illness from which he was known to suffer, which increasingly limited his influence over the journal.

As a former submarine captain in the war, Pezold turned to his contacts in the navy to vouch for his honour and that of his firm. He also activated his völkisch-nationalist networks in his defence, appealing to the son-in-law of the writer Ina Seidel, Ernst Schulte-Strathaus, who worked for the department of culture in the office of the Führer's deputy, Rudolf Hess. Hess had assisted the publishing house in the past. Four days after meeting Schulte-Strathaus, on roth October 1936, Pezold sent letters to Rudolf Hess, as well as Himmler, and to SA-Obergruppenführer Dietrich von Jagow, outlining the position of the publishing house and appealing against the ban on Das innere Reich. Adopting a stance of aggrieved honour, he assured Himmler that he had always upheld the interests of his Volk. Outlining very clearly the injustices done by the Schwarze Korps, Pezold continued with a defence of the völkisch credentials he had brought with 
him to the LMV. ${ }^{41}$ He also suggested that the SS organ had damaged the LMV's reputation as the leading publisher of serious nationalist literature both at home and, especially, abroad, before concluding:

I know how both the open and the hidden enemies of Germany, and especially those the 'Schwarze Korps' wishes to hit, are now laughing up their sleeves, and for the first time I can do nothing to spoil their fun, for I have naturally forbidden all my staff from resisting the decree of the state in defence of the publishing house, and I myself am doing nothing else. For I stand for this state, even when it treats me and my work in the worst possible way - namely takes its honour. ${ }^{42}$

Hans Grimm also wrote to the Foreign Minister, Ribbentrop, while Binding drafted a letter to Goebbels, turning the ban into an attack on all those writers who contributed to the journal; a dangerously large number for Goebbels to alienate. He also suggested that this was an attack on those who fought at the front in the First World War, finally suggesting that Goebbels should place more faith in a publication under his own jurisdiction than in one that was governed by Himmler, one of his rivals in the government. In the end Binding's letter remained unsent. Overall, however, the writers' responses demonstrate the loyalty of those völkisch-nationalist writers closest to Das innere Reich, for whom it was a mouthpiece in an increasingly restrictive regime. ${ }^{43}$ The efforts of Pezold and his allies had the desired effect, moreover, and, probably due to the engagement of Rudolf Hess, the ban was lifted on 23 rd October $1936{ }^{44}$

From its inception, the history of Das innere Reich mirrored the problems of völkisch writers: While, at first, belief in the new beginning heralded by the Nazi 'Revolution' was strong, this never amounted to more than a negative creed, focused on wiping away the evils plaguing Germany. Little that was constructive or new was produced in the literary sphere to take the place of the undesirable writers and works that were removed. As a result,

4I Pezold to Himmler, I4.IO.1936, DLA: Langen-Müller Verlag / Pezold.

42 Ibid.

43 Draft of an undated letter from Binding to Goebbels, October 1936 in Barthels (ed.), Rudolf G. Binding, pp. 340-342.

44 'Erklärung', Das Innere Reich, 1936, Year 3, vol. 3, p. 921. 
the journal and its contributors quickly begin to sound stale. With Das innere Reich, Alverdes and von Mechow, supported in the background by Pezold, sought to create an organ that would represent völkisch thought positively in the Third Reich, and contribute to the ongoing struggle for a volkisch state. To this end, they were willing to work with the Nazis. Inevitably, however, the nature of the journal changed, reflecting the relationships of völkisch-nationalist thinkers with the regime. These, as has already been demonstrated, went from enthusiasm, through tension and outward defeat, to renewed vigour for the German war effort after 1939. Likewise, the enthusiastically proclaimed goals of the journal's editors in 1934 were gradually reined in by pressure from the very state they hoped would enable their achievement. As a result of the ban in 1936 and Pezold's problems and dismissal in the course of 1937 , the articles increasingly demonstrated a retreat towards the aesthetic over the ideological. ${ }^{45}$

The withdrawal of Das innere Reich from the ideological and political spheres was only reversed by developments in Germany's foreign policy in the late i930s. Following the Anschluß of Austria on I2th March, Alverdes looked back in an editorial on the shared past of Austria and Germany. He discussed the Austro-Prussian War, a symbol of unsatisfactory division, but at the same time fundamental in the struggle to define the Germany. He suggested that the camaraderie of the First World War, in which they had fought side-by-side, had been instrumental in bringing the AustrianGermans closer to their brethren in the German Reich. Hitler's Anschluß, he argued brought an end to this chapter of history, finally settling the account:

A new generation, finally certain of its past and even more so of its future, is prepared to live for the Reich and the Reich of all Germans. The day before yesterday it still seemed to be an unachievable dream. One single man has made it reality through his deeds and, after centuries, has reunited brothers with brothers. Now he is calling brothers to bear witness before the whole world. For each other: that is for the National Socialist Reich of all Germans he has created. No German can refuse him this witness! ${ }^{46}$

45 Denkler, 'Janusköpfig', p. 386.

46 Paul Alverdes, “'Brüder”: Zum Tag der Volksabstimmung am ı. April ı938', Das Innere Reich, April 1938 (Jahrgang 5, I. Halbjahr, 1938/39), pp. 100-103. Quotation, p. I03. 
The following month, in May 1938 an entire edition of the journal was devoted to Austria's 'homecoming' to the Reich. It included poetry from Josef Weinheber, Gertrud Fusenegger and Paul Anton Keller, as well as articles by Heinrich Ritter von Srbik and Bruno Brehm, among others. Srbik's article recalled Austria's past, asserting her German nature and stating that she returned to the Reich 'as a limb of the German Volk that has recognised its greater national duty, always fulfilled it loyally and in far posts has protected and valuably extended Germany's soil and inheritance. ${ }^{37}$ Brehm also emphasized the glorious reunification of two parts of one body that had been artificially separated for so long. ${ }^{48}$

Germany's foreign policy from the late I930s therefore provided many of the völkisch-nationalist writers examined in this book with the common cause with the Nazi regime that they had failed to find in the government's Kulturpolitik. Hitler's expansionist policies were easily justified by writers whose ideological foundations were at least partially based on Germany's colonial ambitions in the late nineteenth and early twentieth centuries. The foreign successes of the Nazi government overturned the wrongs of the Versailles Treaty, which, in völkisch eyes, had protected the British monopoly on imperial power. In an 'Antwort auf einen Brief aus England' regarding the annexation of Austria and the Sudetenland, Alverdes explained that Germany was at last breaking down the walls erected in Paris in 1918 that had been suffocating her ever since. The expansion of the Reich into Austria and Czechoslovakia was no less than the reunification of regions and peoples that had naturally belonged together for thousands of years; it was a necessary act of survival. And, Alverdes continued, 'that is one of the reasons for the not only enthusiastic, but at the same time very

47 Heinrich Ritter von Srbik, 'Stirb und werde', Das innere Reich: Sonderheft zur Heimkehr Deutsch-Österreichs ins Reich (May 1938), pp II8-II9; quotation, p. II9.

48 Bruno Brehm, 'Ein Brief aus Wien', Das innere Reich: Sonderheft zur Heimkehr Deutsch-Österreichs ins Reich (May 1938), p. I21. He similarly greeted the annexation of the Sudetenland later the same year: Bruno Brehm, 'Tage der Heimkehr', Das Innere Reich: Zeitschrift für Dichtung, Kunst und deutsches Leben, November 1938 (Jahrgang 5, 2.Halbjahr), pp. 845-858. 
serious and deep support of the German Volk for this act of statesmanship of its Führer.' ${ }^{\prime 9}$

Alverdes reacted similarly to the outbreak of war. His editorial for November 1939 presented an encounter between the author, a veteran of World War One, with a young German, off to join his battalion. The young man in the article represents the voice of the new generation. His understanding of the British, echoing Grimm's work, is juxtaposed with the lack of British understanding of Germany and the Germans. ${ }^{50}$ There was, according to Alverdes' account, inherent hypocrisy in English war policy: on the one hand, the English had conquered the world through might; on the other, they sought to prevent a similar expansion of Germany. Germany had entered the war reluctantly and her soldiers fought without hate, but with an understanding of the urgency to free their land and their Volk from the bonds that had been imposed on them from outside. The war was necessary for Germany's survival because, in the words of Alverdes' young soldier, 'We must now finally gain air to breath for ourselves. ${ }^{\text {.1 } 1}$ In contrast to the generation that fought the First World War, according to Alverdes the young man went to join the battle with a sober heart. $\mathrm{He}$ sought not glory but to rescue his Volk. This was the struggle that would end in absolute victory or in Germany's final destruction. ${ }^{52}$

During the Second World War, Das innere Reich continued to appear monthly until April 1942, when, due to the growing shortage of paper, its output was halved. A year later it became a quarterly publication. Its average length also decreased from 140 pages to 60 pages. ${ }^{53}$ Until it was discontinued altogether in 1944 , it continued to provide its editors and

49 Paul Alverdes, 'Antwort auf einen Brief aus England', Das innere Reich, April 1939 (Jahrgang 6, I. Halbjahr, 1939/1940), pp. 2-7; quotation, p. 3.

so Hans Grimm, 'Englische Begegnung: Entwurf eines Vorwortes', Das innere Reich, Jahrgang 3 , Band 4, 1937, pp. 1197-1207.

5I Paul Alverdes, 'Tagebuch in dieser Zeit: I. Der Reisegefährte, 29th September '39,' Das innere Reich, November 1939 (Jahrgang 6, 2. Halbjahr), pp. 799-805; quotation, p. 800 .

52 Ibid.pp. 803-804

53 Mallmann, Das innere Reich, pp. 66-67. 
contributors with a vehicle with which they could express their support for the German war effort, their faith in German greatness and, towards the end, their consoling belief in the German character and the importance of German art and literature.

\section{The Gleichschaltung of the Publishing Industry}

The history of Das innere Reich was inevitably affected by developments in the LMV as the r930s progressed. The measures established to control German literature in the Third Reich also had a significant impact on the publishing industry. Alongside the direct censorship of authors, which limited the freedom of publishers to control literary output, the government adopted measures aimed directly at the publishing industry. Nonetheless, continuity in publishing was important for the regime's image at home and abroad, and economic considerations meant that the Nazis were concerned to avoid damaging the recovery that gradually gained momentum in the I930s. As a result, the exclusion of Jews from German publishing, as well as the direct control exercised by the Nazi Party over the publishing industry in general, was initially approached cautiously. It was not until 1938 that the most significant Jewish publishing houses had all been closed or taken over by the Eher Verlag, or a Party organization. ${ }^{54}$

The first Nazi encroachments on publishing houses were directed at improving the position of authors in relation to publishers. On the 9th February 1934 an official declaration stated that no manuscript submitted to a publisher for consideration should be held for longer than four weeks without the author receiving notification of a decision or at least provisional decision. ${ }^{55}$ The aim of the RSK and the Department of Literature

54 Barbian, Literaturpolitik, pp. 245-254,

55 E.g. June 1935: Anordnung für Einzelvertreter des Reisebuchhandels; February 1937: Normalvertrag zwischen Verlagsbuchhandlungen und Verlagsvertretern. See Barbian, Literaturpolitk, p. 572. 
was to systematise and 'officialise' the relationship between publishers and writers. The decision-making authority of the RSK over the activities of the leading members of staff in publishing firms became one of the major tools used by the literary bureaucracy of the Nazi regime to steer the production of literature. On the whole, however, the Nazis did not officially exercise preventive censorship; it was not necessary for publishers to present every new book published for approval before its appearance. Instead publishers were held accountable for the publications they produced and could be penalised in the event that they were responsible for the appearance of works deemed unsuitable by the regime. ${ }^{56}$ As the years passed the controls became tighter. Between 1934 and 1937 five Beratungstellen were established to carry out Nazi policy concerning publishing, particularly the 'Aryanisation' of publishing houses through the exclusion not only of Jewish employees, but also works written by Jewish authors and those deemed politically unsuitable. ${ }^{57}$ All five were closely connected to the RSK until early 1937, when their supervision was transferred to the Department of Literature in the Propaganda Ministry, where they were combined in a single department, the Beratungsstelle Verlag. ${ }^{58}$ They nonetheless continued in their function of advising the RSK on the censorship of specific works and mediating between government institutions and publishers. ${ }^{59}$

56 Ibid.

57 The first of these, established in April 1934, was the Beobachtungsstelle für den Reisebuchhandel, which required the registration of all new and re-released travel books as well as any price changes. It was followed by the Anordnung zur Förderung guter Unterhaltungsliteratur in July 1935; the Beratungsstelle für astrologisches und verwandtes Schriftum; the Beratungsstelle für Fachverleger in der RSK, and the Beratungsstelle für das Adreß-und Anzeigenbuchverlags-Gewerbe.

58 Barbian, Literaturpolitik, pp. 569-570.

59 For examples of individual decisions see the letters from the Beratungsstelle Verlag to the RSK asking for the inclusion of Leo Reissinger, Die Handschrift verschweigt nichts (Stuttgart, 1937), 14.7.1937, and Franz Weschke, Beiträge zur Handschriftenbeurteilung (Leipzig, 1937) I5.7.1937 in the lists of 'schädlichen und unerwünschten Schrifttums', B.Arch.R56V(50-05)FB, No. 7. The reasons given in both cases were that the works were 'dilenttantisch', un-scientific and badly-written and would thus lead the layreader astray. See also the correspondence between the Beratungsstelle Verlag 
The National Socialist government was not concerned only with subduing liberal and Jewish publishing houses. It also wanted to control nationalist, right-wing publishing. In 1934, therefore, it established the Parteiamtliche Prüfungskommission zum Schutze des Nationalsozialistischen Schrifttums (PPK). As its name suggests, this was to control literature published with the label 'National Socialist'. ${ }^{\text {'0 }}$ The establishment of the PPK caused considerable consternation among publishers. While on the surface it appeared to be no more than an agency to protect the interpretation of National Socialism, it actually represented the establishment of a monopoly whereby manuscripts of works of a national-socialist nature would be offered first to the central party publishing house, the Eher Verlag. The Eher Verlag therefore became, as Friedrich Oldenbourg, a member of the board of the RSK and the head of the Börsenverein der deutschen Buchbändler, warned Hess, nothing less than the state publisher of political works, given that works which did not conform to National Socialism were prohibited altogether. ${ }^{61}$

At the same time, the Nazi Eher Verlag was also consolidated through the Nazi takeover of private publishing houses. The cases of the Jewishowned Ullstein publishing empire was one of the most notable. ${ }^{62}$ It was, however, only one of seven significant firms, including a number of newspaper producers, bought by the Party and directly administered by the Eher Verlag. In addition Eher gained control of a large proportion of the local press through the Standartes Verlag und Druckerei and the Herold Verlag. These organisations acted as a front for the Party's publishing house,

and the Verlagsbuchhandlung W. Grunow, Leipzig, in 1937, regarding numerous 'Unterhaltungsromane', B.Arch.R56V(50-05)FB, No. 6.

60 Decree issued by Rudolf Hess as the representative of the Führer on I6th April 1934, establishing the 'Parteiamtlichen Prüfungskommission zum Schutze des nationalsozialistischen Schrifttums', in Michaelis and Schraepler (eds), Ursachen und Folgen, vol. IX, pp. 507-508.

6I Barbian, Literaturpolitik, p. Io6.

62 Modris Eksteins, The Limits of Reason: The German Democratic Press and the Collapse of Weimar Democracy (Oxford: Oxford University Press, 1975). pp. 295-301; Oron. J. Hale, The Captive Press in the Third Reich (Princeton: Princeton University Press, I982), p. 106. 
preventing public knowledge of the coercive methods used to take over and run a total of IIs small publishing firms in Germany, and, through the Europa Verlag, 27 German newspapers established in occupied territories. ${ }^{63}$ The full extent of the Eher Verlag was not, therefore, immediately obvious to all, and those publishers it bought out were not always aware how powerful it was becoming. At its height it controlled, either directly, or indirectly through intermediary organisations, one third of the German press and large sections of the book publishing business. ${ }^{64}$

The Nazi rulers also sought to capitalise on right wing cultural movements already in existence during their rise to power. This was both necessary for maintaining the illusion of continuity in the book trade, and ensuring that the volkisch-nationalist writers whose works they published continued to cooperate with the regime. Many of these writers, however, were increasingly disinclined to publish with the Eher Verlag, and determined to maintain at least the appearance of independence from the NSDAP. They hoped the Langen-Müller Verlag and its sister firm, the Hanseatische Verlagsanstalt, and one or two further influential conservative and völkisch publishing houses that had no direct allegiance to National Socialism, would provide homes for their work in the regime. Among the most significant firms were the Munich based J.F. Lehmanns Verlag, and the Eugen Diederichs Verlag of Jena. Both were well-established publishers of right wing intellectual works before World War One. In the interwar period they sought to promote the role of the intelligentsia in an ideal German society, seeking to find the recipe for a conflict-free socio-economic order based on völkisch-nationalist principles to replace the Weimar Republic. Lehmann flirted with National Socialism in $1923 / 24$, but was only finally converted in 1929. In 1931, he placed himself and his firm at the disposal of the Party. ${ }^{65}$ After 1933 , the J.F. Lehmann Verlag and its proprietor were honoured by the Nazis for their work for the movement and the role they

63 Hale, The Captive Press, p. 325.

64 S. Noller and H. von Kotze (eds), Facsimile Querschnitt durch den Völkischen Beobachter (1967), pp. 4-6; see also Hale, The Captive Press, pp. 15-16.

65 Quoted by Stark, Entrepreneurs of Ideology, p. 223; see also Lehmann (ed.), Verleger J.F. Lehmann, pp. 78-79. 
played in helping the Nazis to power. Nevertheless, with the Nazis in power, the political role of the publishing house became increasingly obsolete and it returned to its original function, the publication of works of medicine, 'racial science', and technical and military affairs. The company did, however, continue to thrive in the Third Reich. It opened a new branch office in Berlin in $1938 / 39$ and was the recipient of an award to honour its 'exceptional achievements as a model enterprise. ${ }^{66}$

While Lehmann bridged the gap between the völkisch-nationalists and the Nazi movement, other völkisch-nationalist publishers had greater trouble, including the Eugen Diederichs Verlag and the Langen-Müller Verlag. ${ }^{67}$ Eugen Diederichs died in 1930 and was never forced to confront the realities of the Third Reich. His sons, Peter and Niels soon realised that the Nazis were not going to deliver the social revolution they hoped for. On inheriting the firm they gave the editors of the company's journal, Die Tat, complete independence in its management. In the early 1930 s it became a leading right-wing voice against the Nazis. Following the bookburning of May 1933, right-wing publishing houses, like those on the left, were subjects for the Gleichschaltung of the book trade. It quickly became clear that the Nazis were intent on eradicating criticism in all its forms. The Nazi acquisition of power therefore meant the end of the independent role of the völkisch-nationalist publishers. Since his death left him unable to threaten the Nazi system, Eugen Diederichs himself was the subject of praise for his vision of an 'organic society' based on the German Volk. His sons nevertheless steered a safe course during the Third Reich, publishing volumes of poetry, fiction, travelogues, works on religion and folklore, and 'classic' German authors like Luther, Herder, Goethe or Jahn. ${ }^{68}$ Under pressure from the Nazi government, Die Tat was closed down in $1935 .^{69}$

66 Stark, Entrepreneurs of Ideology, pp. 228-229.

67 On the fate of the LMV see below, pp. 237-245.

68 The inclusion of Peter Diederich's name on the list of participants at the Großdeutsches Dichtertreffen in 1942, alongside many other völkisch-nationalists and Nazi officials, is one example of his ongoing activity in the literary sphere during the Third Reich, B.Arch.R56V-I2.

69 Stark, Entrepreneurs of Ideology, pp. 232-234; Kurt Sontheimer, 'Der Tatkreis', Vierteljahreshefte für Zeitgeschichte, Jahrgang 7, Heft 3 (1959), pp. 229-260; Florian 


\section{The Langen-Müller Verlag}

Of all the independent nationalist firms, however, perhaps the most significant in the I930s was the Langen-Müller Verlag, which, like the Literature Academy, was instrumental in cementing the ties between völkisch-nationalist writers in the Third Reich. Of the fourteen writers called to join the reconstituted Literature Academy in 1933, it was responsible for the publication of all or some of the works of nine. Moreover, alongside Hanns Johst, Hans Grimm, Erwin Guido Kolbenheyer, Wilhelm Schäfer, Emil Strauß, Paul Ernst, Hans Friedrich Blunck, Friedrich Griese and Joseph Magnus Wehner, numerous prominent names in wider völkisch-nationalist and conservative literary circles published their works through the LMV. ${ }^{70}$ Paul Alverdes, Konrad Beste, Hermann Claudius, Richard Euringer, Knut Hamsun, Karl Benno von Mechow, Selma Lagerlöf, Heinz Steguweit, Josef Magnus Wehner and Ernst Wiechert all helped make the publishing house the leading 'Dichterverlag' of the Third Reich. ${ }^{71}$ The LMV enabled its authors to claim the right to belong to an organic intellectual elite as the interpreters and mediators of the Volksseele. As a result it became a refuge for völkisch-nationalist authors who sought to preserve the integrity of German literature from the demands of a party programme. The introduction to the firm's 1933 prospectus was explicit; the publishing house, it declared, was not concerned with the promotion of Party writers. ${ }^{72}$

Before 1933 the LMV already counted among the leading right-wing publishing houses in Germany, and the early years of the Third Reich saw its continued success. Initially the ownership of the house by the DHV remained unchanged. However, when Hermann Miltzow, already a member of the NSDAP, replaced Hans Bechly as director of the DHV, the LMV

Triebel, Der Eugen Diederichs Verlag, 1930-1949: Ein Unternehmen zwischen Kultur und Kalkül (Munich: C.H. Beck, 2004), pp. 298-299.

70 Barbian, Literaturpolitik, p. 77; Brenner, Ende einer bürgerlichen Kunst-Institution, pp. 13-14; Meyer, Die Verlagsfusion Langen-Müller, pp. 207-209.

7 I Lokatis, 'Hanseatische Verlagsanstalt', p. 4.

72 Meyer, Die Verlagsfusion, p. 216. 
was brought under nominal Nazi direction. In 1934, along with all trade union organisations, the DHV was incorporated into Robert Ley's Deutsche Arbeitsfront (DAF), which took over control of its publishing enterprises. In addition to its own 'Verlag der Deutschen Arbeitsfront', it now owned the Hanseatische Verlagsanstalt and the LMV. Meyer notes that as a result of this change a considerable number of the most prominent authors in Germany at this time published their works in a publishing house that was directly owned by the Nazi Party. As far as the LMV was concerned, however, there is little evidence that the DAF involved itself in the literary details of its business, reserving its concern largely for its economic viability. ${ }^{73}$ For a time, therefore, Pezold was largely left to his own devices by his new masters.

The LMV's identity as a völkisch rather than Nazi publishing house nonetheless made it vulnerable to the Nazis who viewed it as competition to their own literary concerns. ${ }^{74}$ Pezold was quick to recognise this situation and went to considerable lengths to cultivate contacts with those in influential positions. He made the most of his good relations with the Brown House in Munich in his efforts to safeguard the LMV's independence. He was also aided by the fact that a number of the most prominent authors published by the LMV were members of the NSDAP or Rosenberg's Kampfbund für deutsche Kultur, among them Johst, Schäfer, Kolbenheyer and Strauß. He turned to Johst, for example, with a generous royalty payment and requested that he organise meetings for him with important men in Berlin. Initially, these efforts were successful, and in April 1934 he was able to boast of a collection of powerful connections, including Dr. Wismann; Rust; the secretary of the KfdK, Dr. Urban; the director of the Reichsstelle zur Förderung des Deutschen Schrifttums, Habemeyer; and finally the Führer's deputy, Rudolf Hess. ${ }^{75}$

Pezold wanted to establish a sphere of influence for the LMV in the new regime. ${ }^{76}$ The autonomy of the firm was also vital to the ambitions

Mallmann, Das Innere Reich, p. 45.

74 Stark, Entrepreneurs of Ideology, p. 230.

75 Meyer, Die Verlagsfusion, p. 209.

76 Lokatis, 'Hanseatische Verlagsanstalt', pp. I02-103; Meyer, Die Verlagsfusion, p. 208. 
of its most prominent völkisch-nationalist writers, as Grimm pointed out to Kolbenheyer on 2nd August 1934. Emphasising the importance of the independence of German writers and publishers for the reputation of German literature abroad, he made it clear that he was prepared to take advantage of the terms of his contract with the LMV should the publishing house come under the direct control of the Nazi Party. In such a case, he assured Kolbenheyer that he would terminate his association with it and move his works to one of the dwindling number of independent publishing houses. ${ }^{77}$ Grimm encouraged Kolbenheyer to do the same, pointing out that the latter's contract with the publishing house was similar to his own. In the case of such an eventuality, Grimm clung to the belief in joint action that also underpinned the co-operation of the Munich Consensus, although he made it clear that he would act alone if necessary.

The LMV's reputation for independence rested to no small extent on the way in which the firm presented itself, over which Pezold exercised considerable influence. ${ }^{78}$ Rather than favouring ownership by a Nazi organisation, Pezold tolerated it as unavoidable. Defending himself and the LMV after 1945, he wrote: 'The Langen-Müller Verlag was, in spite of the fact that from the beginning of the Third Reich it was owned by a party organisation, never a "Nazi publisher" in terms of ethos. ${ }^{\text {'79 }}$ Pezold's reference to the ethos of the firm is the key to the LMV's understanding of itself in the Third Reich. It reflected its völkisch-nationalist roots, which emphasised the decisiveness of the German Geist over all else. After 1933, Pezold put his energies into achieving the LMV's goals, set out in the early I930s, regardless of the ambiguous proprietary situation. The image of the LMV at home and abroad as guardian of serious German literature was, moreover, recognised and even encouraged by the authorities. The VicePresident of the RSK and member of the board of directors of the LMV,

77 Grimm to Kolbenheyer, 2.8.1934, DLA - A: Grimm, Grimm to Kolbenheyer, 1933-1959.

78 Lokatis, 'Hanseatische Verlagsanstalt', p. 102.

79 Gustav Pezold, 'Über den Verlag Langen-Müller u. seinen Autor Erwin Guido Kolbenheyer', DLA - A: Alverdes, Gustav Pezold, versch. Also quoted in Meyer, Die Verlagsfusion, p. 217. 
Wilhelm Baur, for example, declared at a board meeting in 1938 : 'We want to create a global publisher with a high reputation beyond Germany's borders. ${ }^{80}$ By this stage the publishing house was finally under full Nazi control and Pezold had been dismissed the previous year. Nonetheless, the image of the firm as a publisher of good German literature, with a strong reputation abroad as well as in Germany, was one the directors wished to preserve.

Cracks began to appear in Pezold's control of the LMV by the midI930s. In 1935, Werner Bergengruen, Konrad Beste, Hans Friedrich Blunck, Richard Euringer, Heinz Steguweit, Ludwig Tügel, Josef Magnus Wehner and Wolf Justin Hartmann all transferred their allegiance from the LMV to the Hanseatische Verlagsanstalt, which was by now securely under the Party's influence. ${ }^{81}$ Pezold's dismissal in 1937 finally came after twelve months of wrangling with the DAF over the position of the LMV. On Ioth December 1937 he wrote to Hans Grimm, ${ }^{82}$ reporting on a series of meetings that had taken place in Berlin. Pezold had been summoned to appear before the board of directors of the LMV, dominated by the DAF, the following Wednesday; his instincts told him that the situation was coming to a head. ${ }^{83}$ Ten days later, in a second letter to Grimm, he explained further that the board had hitherto been hesitant to act due to concern regarding the nature of the contracts between the LMV and some of its most prominent authors, most notably Grimm and Kolbenheyer. By the end of 1937, sure of support from the RSK, which, Pezold assumed, would simply declare such contracts invalid, it nonetheless dismissed the managing director of the LMV; Pezold was finally removed from his post in January $1938 .{ }^{84}$

$80 \quad$ Ibid. p. 217.

8I In comparison to the LMV, the HAVA's programme took a very different course after 1933, carving out a niche for itself by publishing in particular political and historical works in line with the Nazi ideology, for Nazi institutions, and by members of the NSDAP. See Lokatis, 'Hanseatische Verlagsanstalt'.

82 Grimm to Kolbenheyer, 2.8.1934, DLA - A: Grimm, Grimm to Kolbenheyer, 1933-1959.

83 Pezold to Grimm, 10.12.1937, DLA: Pezold to Grimm, 1937-1938.

84 Pezold to Grimm, 20.12.1937, DLA: Pezold to Grimm, 1937-1938. 
Pezold was replaced as the managing director of the LMV by Walter Fischer, not yet a member of the NSDAP but already trusted by the Nazidominated board. Following Pezold's dismissal only Reinhold Geheeb and Korfiz Holm remained of the Langen-Müller stalwarts, supervising the firm's literary concerns until their deaths in 1939 and 1942 respectively. In 1943 the firm was taken over by the Knorr \& Hirth Verlag, thereby becoming part of the Eher empire. The LMV was closed by the Allies in 1945, along with all Nazi Party enterprises. After the war, it was eventually granted a license by the American occupation authorities, but it was only re-established under its old name in 1952 after the license requirement had been revoked. And Pezold's ambitions to regain control did not come to fruition.

After 1945, Pezold suggested that his dismissal was the result of ideological considerations that made him unacceptable to the Nazi leadership. ${ }^{85}$ It is likely, however, that it had more to do with his determination to retain control over the LMV and maintain its independence as a völkisch-nationalist concern, which certainly did not endear him to the firm's Nazi owners. This was manifested in his refusal to write a report on his activities for the board of directors, which he felt had been imposed on his publishing house against his wishes. He also resisted the appointment by that body of Benno Ziegler, the director of the Hanseatische Verlaganstalt, as co-director of the LMV. Ziegler, he told Grimm in December 1937, was under pressure to take up a position on the board of the LMV. This, he was told, would be a mere formality, necessary due to Pezold's ill health. According to Pezold, however, Ziegler had seen through the game and refused. Pezold also objected to the appointment of an additional commercial director for the LMV. ${ }^{86}$

In addition, the attitude of leading writers like Grimm and Kolbenheyer towards the regime is likely to have influenced the decision to dismiss Petzold. Among the most prominent authors of the LMV, reactions to Pezold's dismissal were overwhelmingly negative. For many, Pezold was the heart of the LMV, but his departure was also a sign of a larger problem

85 Meyer, Die Verlagsfusion, p. 218.

86 Pezold to Grimm, I0.12.1937, DLA: Pezold to Grimm, 1937-1938. 
in German literature. Kolbenheyer summed the situation up in a letter to Grimm on 19th January 1938 , in which he presented a pessimistic, but ultimately accurate assessment of the situation. He demonstrated little hope for Pezold's reinstatement as director of the publishing house, even after the ongoing appeals to the highest authorities in the DAF. He then went on to examine how much freedom Grimm, Schäfer, Strauß and he himself possessed. Schäfer and Strauß, he concluded, were bound, like the majority of the house's authors, to stay with the publishing house. As far as he himself was concerned, his contract allowed him to withdraw his work if certain conditions outlined in the contract were not met. By this time, Kolbenheyer had developed a personal dislike of Pezold and his reluctance to leave the publishing house was predictable. ${ }^{87}$ That left only Grimm with the freedom to choose. ${ }^{88}$

Grimm responded to Kolbenheyer by explaining that the decision whether to stay or leave the LMV, so long threatened, in the end depended less on Pezold's dismissal than on his already very apparent displeasure with the overall direction in which the LMV was developing:

Things won't be improved just by returning P. to his office, as long as the present board of directors continues to exist and the [business of the] greatest national publishing house is disrupted by the personal whims of wholly lightweight and incapable people. It therefore depends on whether, first of all, a more worthy situation can be found for the entire firm. [...] The men on the board of directors do not comprehend and are also incapable of comprehending that this publishing house must remain untouched simply for reasons of foreign policy. The publishing house will, however,

87 In a letter to Kolbenheyer on 29.1.1937, Grimm exhorted Kolbenheyer not to let his personal dislike of Pezold get in the way of his actions regarding the publishing house: 'I am naturally aware that you yourself are not particularly fond of Herr Pezold. I would nonetheless like to ask you not to let that lead you to make a mistake. For, even if initially the officious men only look to Pezold in isolation, that is only in order that, eventually, they will be better able to get at individual authors [...].' Grimm to Kolbenheyer, 29.I.1938, DLA - A: Grimm, Grimm to Kolbenheyer, 1933-1939. See also Gustav Pezold, 'Über den Verlag Langen-Müller u. seinen Autor Erwin Guido Kolbenheyer', DLA - A: Alverdes, Gustav Pezold, versch.

88 Kolbenheyer to Grimm, 19.1.1938, DLA - A: Grimm, Kolbenheyer to Grimm, I918-1938. 
not remain untouched as long as it is subordinated to the A.F. [Arbeitsfront] or is otherwise used as a commercial object and sold off to another publishing house, the name of which I do not want to mention here. ${ }^{89}$

Grimm concluded by explaining to Kolbenheyer that at the time of writing, he was only waiting to see whether the publishing house could be rescued. To that end, he informed Pezold in a letter on Isth May 1938, he did not hold back from writing to the head of the DAF, Robert Ley, to communicate his concerns. He would, he told Pezold, wait fourteen days for Ley's answer. Pezold's response to Grimm demonstrated his own continued loyalty to the firm he had done so much to shape, and his concern for its future, even after his dismissal. On I8th May 1938 he wrote: 'With regard to the publishing house, the conversations in Berlin resulted in one clear impression [...], namely that it is seen as a non-independent organisation that can be commanded at will. ${ }^{90}$ Both Pezold and Grimm were reluctant to view the unsatisfactory situation as final, no matter how hopeless it looked. While positive change appeared increasingly unlikely, Pezold nonetheless sought to encourage Grimm to stay with the LMV. As far as the former director was concerned, Grimm's departure would be the final nail in the firm's coffin: 'The Langen-Müller Verlag will then lose its crown and will no longer be able to be what it was. ${ }^{91} \mathrm{He}$ also pointed out that by leaving, Grimm would relinquish any part he might be able to play in future developments.

Grimm did not remain with the LMV. In February 1938, he wrote to Schäfer, informing him that he had given notice of his departure and again asserting that he was only waiting to see whether the firm could be rescued. He would not, he declared, remain with a publishing house that was not completely independent. ${ }^{92}$ In August he transferred his work to the Bertelsmann Verlag, which was still privately owned. He told Schäfer

89 Grimm to Kolbenheyer, 23.I.1938, DLA - A: Grimm, Grimm to Kolbenheyer 1933-1959.

90 Pezold to Grimm, 18.5.1938, DLA: Pezold to Grimm, 1937-1938.

9 I Ibid.

92 Grimm to Schäfer, 6.2.1938, DLA - A: Grimm, Grimm to Schäfer, 1928-1950. 
that this was necessary for political reasons; his future work, he said, would concentrate to a significant degree on foreign affairs, in particular GermanEnglish relations. As a result, he felt it was necessary that he publish only with a firm that was viewed, both in Germany and abroad, as politically neutral. The Bertelsmann Verlag had been courting Grimm since the early I930s and he was therefore able to negotiate excellent terms for his contract. While his biggest project during the Third Reich, Heynade und England, was never completed, he did achieve success with the publication of the Englische Rede: Wie ich den Engländer sehe, brought out by Bertelsmann in October $1938 .{ }^{93}$ Moreover, the continued appearance of Volk ohne Raum under the Bertelsmann imprint in no way damaged its popularity; by 1944 over half a million copies of the single-volume Volksausgabe had been sold. ${ }^{94}$

Due to the outbreak of the Second World War a year later, it is difficult to assess whether changing publishers made a significant difference to Grimm's long-term fortunes in the Third Reich. By 1943, due to severe paper shortages, little could be published that did not directly contribute to the war-effort. During the war, the Bertelsmann Verlag focused almost exclusively on producing volumes of stories and tales of adventure, largely destined for the front. These Feldausgaben of previously published works were uncontroversial with the Nazi rulers and produced in huge quantities, some reaching two digit editions and print runs of 300,000 or more. ${ }^{95}$

It is also difficult to assess the effect of the changes in the LMV on those who stayed. While it is noticeable that by the end of 1938 many völkischnationalist writers were withdrawing from the public sphere, the war altered their political frame of reference, providing them with a common cause with the Nazis to which they could devote themselves with renewed

93 Friedländer et al., Bertelsmann im Dritten Reich, pp. 377-382.

94 The single-volume edition of Volk ohne Raum published by Bertelsmann in 1944 covered numbers 486,000 to 505,000 .

95 For example, copies 71,000 to 100,000 of the Feldausgabe of Herbert Volck, Die Wölfe, were printed in 1942 , being copies 272,000 to 301,000 of the total editions of this work. Likewise the edition 10 6,000 to 135,000 of the Feldausgabe of P.C. Ettighoffer's Nacht über Sibirien, published in 194I, was numbers 331,000 to 360,000 of the total editions. 
vigour. The history of the LMV up to the outbreak of the war nonetheless represents a significant chapter in the history of völkisch-nationalism in Germany in the I930s, illustrating not only the conflicting agendas of the Nazi government and some völkisch-nationalist writers, but also the efforts of the latter to maintain institutions through which they could disseminate their point of view. That this was possible for the first five years of the Third Reich was due to a lack of good writers in the Party's own ranks. As a result, the Nazis were forced to promote those völkisch-nationalist writers whose work could be used to promote Nazi ideology. As the case of Hans Grimm demonstrates, this did not make them into 'NS-Dichter'. Their relationship with the regime was more complex, a situation also reflected in the history of Grimm's Lippoldsberger Dichtertage in the r930s.

\section{'Es soll keine Freude mehr geben ausser der konzessionierten': ${ }^{96}$ Hans Grimm and the 'Lippoldsberger Dichtertreffen' ${ }^{97}$}

Even before 1933 Hans Grimm's political engagement and contacts in the Nazi Party combined with the success of his novel Volk obne Raum gave him prominence in right-wing literary circles. In the course of the r 930 s he became one of the most outspoken representatives of völkisch-nationalist literature, attracting the attention of both the German public and several of the highest-ranking government officials with his opinions. Above all,

96 Börries Freiherr von Münchhausen, Wartburg Tagebuch 1936, DLA: Nachlaß Grimm, Münchhausen to Grimm.

97 An earlier version of this section was published in Guy Tourlamain, "'In Defence of the Volk": Hans Grimm's Lippoldsberger Dichtertage and völkisch Continuity in Germany before and after the Second World War', Oxford German Studies, vol. 39, No. 3 (2010) pp. 229-249 (www.maneyonline.com/ogs). I would like to thank the editors, Jim Reed and Nigel Palmer, and Maney Publishing for permission to reuse this material. 
however, the annual Dichtertreffen held at his home in Lippoldsberg an der Weser damaged his relations with the Nazi hierarchy. Ernst von Salomon devoted several pages of Der Fragebogen to a description of Hans Grimm and the Dichtertreffen that took place between 1934 and 1939. According to Salomon Grimm was a 'Dichter mit Landhaus', Salomon's categorisation of those völkisch-nationalist writers who lived in the country and devoted their literary energies to the eternal values of the Blut-und-Boden literature they espoused. They spoke, he said, of the soil, the smell of the earth, and the people most closely connected to the land. ${ }^{98}$

In May 1939, Goebbels demanded a report on the existing Dichterkreise, or writers' circles, in Germany. His request showed his concern at the number of independent and often informal groups operating in the German literary sphere. The results of the enquiries undertaken by the staff of the Propaganda Ministry identified nine functioning groups. ${ }^{99}$ Membership lists showed moreover that some writers were involved in more than one group; Hans Friedrich Blunck, for example, was a member of at least three. ${ }^{100}$ Of the nine groups, however, only two were of real political significance: the Wartburg-Treffen, the brainchild of Börries Freiherr von Münchhausen, which was eventually subsumed into the Nazi Party's own Woche des deutschen Buches in Weimar, and Grimm's Lippoldsberger Dichtertreffen. While the two were initially motivated by similar concerns, they were very different in organisation, form and impact, reflecting the different characters and priorities of their originators. While Münch hausen's meetings increasingly took on a semi-official nature in the course of the 1930s, Grimm's more independent initiative had a greater impact in Germany.

98 Salomon, Der Fragebogen, pp. 192-193. This work was based on Salomon's answers to an allied questionnaire and is an attempt to explain the German position regarding the Nazis after 1945 .

99 Report for Johst, RSK Berlin, 26.8.1936, B.Arch.R56V-I2; see also memorandum from Bischoff to Ihde, in the RSK, 'Zusammenstellung der jetzt bestehenden Dichterkreise,' 27.7.1938, B.Arch.R56V-77; Wulf Segebrecht (ed.), Der Bamberger Dichterkreis, 1936-1945: Eine Austellung in der Staatsbibliothek Bamberg (Bamberg: Lang, 1987).

Io० Internal memorandum to Ihde in RSK, I0.9.1938, Betrifft: Dichterische Gemeinschaften, Kreise, Veranstaltungen etc. im Reich', B.Arch.R56V-77; See also Mittenzwei, Der Untergang einer Akademie, p. 427. 
Münchhausen began to develop the idea of the Wartburg as the seat of a German Writers Academy in the early I930s. In doing so, he took a stand against the Literature Section of the Prussian Academy of Arts following the resignation of Kolbenheyer, Schäfer and Strauß in January 1931. In establishing the Wartburg Circle, he relied on support from prominent Nazis. In Burg Saaleck, the home of the conservative architect Paul Schultze-Naumburg, he regularly met not only with the architect himself, but also Hans Severus Ziegler, Wilhelm Frick, Richard Walter Darré and Baldur von Schirach. With Frick's help he was able to overcome initial resistance from the Wartburg Foundation, which was responsible for the site itself. As Thuringian Minister of State in 1930-1931, Frick briefly served on the Foundation's governing board and championed Münchhausen's suggestion that the Wartburg Foundation should support an annual meeting of writers and establish a literature prize. The first recipients of the Wartburg Prize were Hermann Stehr, Erwin Guido Kolbenheyer and Paul Ernst. ${ }^{101}$

In addition to the prize, worth 2,000 RM, Münch hausen introduced the idea of Wartburg Roses, designed as badges of honour in recognition of services to German literature. He desired the establishment of an elite order of Knights of the Rose, limited in number and representing the essence of German literary life. His efforts did not meet with unequivocal approval from his völkisch-nationalist colleagues. Wilhelm Schäfer, for example, wrote to Hans von der Gabelentz, the Burg Hauptmann at the Wartburg, expressing scorn for the Roses and distancing himself from the initiative. ${ }^{102}$ The first Wartburgdichtertagung was held on 29th and 30th May 1932. Among those invited were Hans Grimm, Hanns Johst, Hans Friedrich Blunck, Will Vesper, Erwin Guido Kolbenheyer, Paul Ernst, Hermann Stehr, Agnes Miegel and Heinrich Lilienfein. Grimm and Johst turned the invitation down, the latter expressing sincere regret. ${ }^{103}$

The Wartburg was important to Münchhausen as a place where the literary elite could be protected from the influences of the cities and aesthetic modernism. Despite financial pressures, he succeeded in staging

IOI Mittenzwei, Der Untergang einer Akademie, pp. 175-178.

IO2 Ibid. pp. 175-176.

IO3 Ibid. p. 178 . 
a successful meeting in 1933, at which Wartburg Roses were awarded to Hermann Stehr, Erwin Guido Kolbenheyer, Paul Ernst, Heinrich Lilienfein and Münchhausen himself. ${ }^{104}$ In 1934 no meeting was held, but in 1935,1936 and 1937 they followed annually. The Wartburg was thus prepared to take up the reins should the Literature Academy in Berlin run out of steam, an inevitable outcome in Münchhausen's eyes. ${ }^{105}$ Münchhausen nonetheless faced limitations in establishing the Wartburgdichtertage that Hans Grimm did not experience with the Lippoldsberger Dichtertreffen. Not the least of these was his dependence on outside organisations to achieve his goals. The Wartburg Foundation demonstrated reluctance to limit itself to the role of financial provider, while Münch hausen was determined to decide himself who should be invited to attend the meetings, and who should be admitted to the Rosenritterschaft. He also had to contend with the Nazi authorities in Thuringia and Berlin. In order to keep their involvement to a minimum he went to great lengths to cultivate his contacts among highranking Nazis, not least Rudolf Hess and his adjutant Schulte-Strathaus. The latter was the son-in-law of his friend Ina Seidel. ${ }^{106}$

The Rosenritterschaft remained very close to Münchhausen's heart throughout the history of the Wartburg meetings. It was therefore with significant regret that he was forced in 1938 to accept the end of its short life. The other Rosenritter, however, had consistently displayed less enthusiasm for the project. ${ }^{107}$ The deathblow came from Goebbels and the propaganda office in Thuringia. In May 1938 the Mayor of Eisenach and chairman of the Wartburg Foundation, Janson, was informed that the Propaganda Minister had decided that the Wartburgdichtertage were to be replaced by a 'Deutscher Dichtertag auf der Wartburg' as part of the 'Woche des deutschen Buches 1938' in Weimar. In the end, plans to invite two hundred writers to the Wartburg were changed and the event was held in Weimar.

I04 Münchhausen to Grimm, I.I2.1933, DLA - A: Grimm, Münchhausen to Grimm, 1927-1945; Mittenzwei, Der Untergang einer Akademie, pp. 176-177.

Io5 Mittenzwei, Der Untergang einer Akademie, pp. 409-4IO.

I06 Ibid. p. 4IO.

107 Ibid. p. 424. 
The days of the Rosenritter and the Wartburgdichtertage had passed. ${ }^{108}$ More generally, many völkisch-nationalist writers were increasingly retreating from the public sphere, disillusioned with the course the Third Reich was taking. Hans Grimm's Lippoldsberger Dichtertreffen, on the other hand, came to occupy an increasingly important place in the völkisch literary calendar in the 1930s, and made a significant contribution to keeping völkisch literary networks alive. Held annually between 1934 and 1939, these events were originally conceived as an opportunity to bring like-minded writers of the older and younger generations together. In the first instance, the writers invited to take part were bound by their common experience of the First World War, whether like Binding and Grimm they had volunteered in early middle age, or, like Alverdes and von Mechow, they had gone to the front straight from school. The Lippoldsberger Dichtertreffen not only forged acquaintanceships and nurtured the networks of writers in private; they raised awareness and enthusiasm for their literature in public. The initiative differed from Münchhausen's Wartburgdichtertage in several fundamental ways. As well as combining informal, private interaction between writers with public musical and literary events, the profile of participants was more diverse in Lippoldsberg. One of Grimm's intentions from the outset was to enable young nationalist writers to mix with their older, established colleagues. Another major strength of Grimm's Lippoldsberger Dichtertreffen was their more organic, less contrived development in comparison with the Wartburgdichtertage.

The idea for the meetings went back to 1930, and was given further impetus by a suggestion made by Münchhausen at one of the meetings of the Literature Academy in October 1933, to which Grimm responded positively, writing to Binding on 3rst October 1933: 'Münch hausen's suggestion of a day for young writers makes excellent sense to me. ${ }^{109}$ When this event did not occur under the auspices of the Academy, Grimm decided to make it happen himself. He was further motivated by his attempts to bring the Munich Consensus together in early 1934 to discuss

IO8 Ibid., pp. 42I-425.

I09 Grimm to Binding, 31.10.1933, DLA - A: Grimm, Grimm to Binding, I933-I934. 
the problems of the Literature Academy. The form the Dichtertreffen would take began to emerge as he tried to organise a meeting between Binding, Kolbenheyer, Schäfer, Strauß and himself. Suggesting a date in March 1934, he offered his home in Lippoldsberg as a venue, adding in a letter to Schäfer that he would be in a position to use a house in the village owned by the nearby University of Göttingen to accommodate his guests. They could then conduct relaxed discussions over several days, during which the guests would have complete freedom to come and go as they pleased. ${ }^{110}$ While this meeting did not take place as Grimm suggested, he nonetheless adopted this plan for the writers who attended his Dichtertreffen. With the use of the university's house, he was able to build on the success of the first, small meeting in 1934, and to invite more writers in subsequent years.

From their inception the Lippoldsberger Dichtertreffen were politically as well as artistically motivated. They developed out of Grimm's desire for völkisch-nationalist writers to develop and maintain contact in the Third Reich. Outside the realm of Nazi influence, most meetings lasted five days. From the second year, 1935, the Sunday became a day for the public. Thousands came to hear the musical and literary performances, mingle with the writers, buy their books and enjoy the idyllic surroundings of Lippoldsberg. In addition, one or two evening readings were staged each year for military units stationed in the vicinity of Lippoldsberg. ${ }^{111}$ Grimm's view of the army as representing something intrinsically 'German', the foundation for the defence of the Fatherland, reflected the way in which völkisch-nationalists accepted military actions as necessary for the fulfilment of the German national cause. This was also evident in their positive responses to the 'Anschluß' with Austria, the annexation of the Sudetenland and the outbreak of the Second World War. ${ }^{112}$

IIo Grimm to Schäfer, 25.3.1934, DLA - A: Grimm, Grimm to Binding, I933-1934.

III Grimm to Pezold, I4th July 1938, DLA - A: Grimm, Grimm to Pezold, 1938-1946.

II This should not be taken to mean that Grimm, for example, was pleased at the outbreak of the Second World War - see, for example letter to Pezold, 25th March 1939 in which he states his worries regarding Germany's relationship with Britain, but there was no doubt once war had been declared where his loyalties lay. See Grimm 
With the exception of the public Sundays and the evenings orgainised for the troops, the remaining days of the Lippoldsberger Dichtertreffen were free for writers to relax and talk, Grimm's hospitality guided by his desire to facilitate social and professional interaction and candid discussions on all subjects, particularly literature and politics. He also hosted several formal evening meals at which the guests were brought together as one group. ${ }^{113}$

Although the meetings lasted much longer, the annual Sunday festivities inevitably did most to influence the way in which the Lippoldsberger Dichtertreffen were viewed by the public. Their development occurred largely due to demand from outside. As part of the first meeting in 1934, Grimm had organised an evening of readings by the writers in attendance for local units of the Reichswehr. A great success, in subsequent years this evening was repeated and the numbers invited increased. Nonetheless, this did not address the growing interest of the wider public in what was going on in Lippoldsberg. This demand was met by the Sunday events, including a morning concert by the Akademischer Orchester-Vereinigung Göttingen $(\mathrm{AOV})$ in the church that adjoined Grimm's home. The involvement of the orchestra was not the result of Grimm's initiative, but of the orchestra's chairman, Studienrat Willi Rehkopf. ${ }^{114}$ The musical contributions intentionally focused on German composers of the past, Rehkopf's concept of concerts that would revive Germany's musical heritage fitting in well with Grimm's völkisch-nationalist ideology and his goals for the meetings. In a review of the 1935 meeting by Dr. Max Maass in the Hannoverscher Kurier on 2 nd July 1935 it was reported that the music selected that first year was by the seventeenth-century German composer Heinrich Schütz. According to Maass, the church was full beyond its capacity with listeners sitting on the steps and the altar, and many being forced to stand. He continued:

In the villages the audiences are much more receptive, for they have a more natural comprehension. Such concerts are like devotions, they are not only to be enjoyed,

to Pezold, 25.03.1939, DLA - A: Grimm, Grimm to Pezold, 1938-1946. See also discussion of German foreign policy in Inneres Reich, Chapter 4, pp. 229-232.

II3 Salomon to Grimm, 24.7.1934, DLA - A: Grimm, Salomon to Grimm, 1934-1952.

II4 Gerd Koch, '1936: Dichtertreffen bei Hans Grimm in Lippoldsberg', pp. 337-349. 
but they shape and form, they thereby fulfil the highest meaning of art. And that was also bestowed on us at Lippoldsberg, because the surroundings had a simplifying effect on the city-dweller used to concert halls, and made him [or her] noticeably more receptive. $^{115}$

Press reports of the meetings in Lippoldsberg mainly focused on the day for the public. A special train, chartered by the orchestra, brought the musicians and public, about 500 people, from Göttingen as far as Bodenfelde, whence it was a half-hour walk along the river to Lippoldsberg. ${ }^{116}$ The Göttinger Tageblatt described the walk from Bodenfelde along the Weser, 'the current of Lower Saxony', as following the 'path of the fate' of pilgrims of earlier centuries to Lippoldsberg. The stone gateway of Grimm's home ceremoniously welcomed them to the old convent. ${ }^{117}$ While the orchestra was responsible for organising transportation, it was not the only organisation that went to lengths to get people to the events. For example, the Bücherstube Seifert in Hameln an der Weser organised two buses to transport the citizens of that town to Lippoldsberg in $1936 .{ }^{118}$ Journalists' estimates of the number of participants for 1935 vary between I,000 and 2,000, most of them coming from Göttingen, Hanover, Kassel and the neighbouring towns and villages, but also quite a few from further afield in Germany. They gathered in the courtyard of the former convent to listen to German music and German writers.

As the backdrop to Volk obne Raum, the location of the Lippoldsberger Dichtertreffen in the Weser Valley added to its symbolic significance. The public enjoyed the atmosphere in the surroundings in which Grimm's hero, Cornelius Friebott, grew up, whilst listening to prominent and popular writers read from their work. Over a lunch of pea soup provided by the

II Max Maass, 'Dichtertreffen bei Hans Grimm: Besuch in Lippoldsberg an der Weser', Hannoverschen Kurier, Nr.302, Jahrgang 1935, 2nd July 1935, DLA - A: Grimm, Dichtertage - Zeitungsberichte 1935-1936.

II6 Max Maass estimated that 500 visitors arrived by train in 'Dichtertreffen bei Hans Grimm: Besuch in Lippoldsberg an der Weser.'

II7 Jürgen Schüddekopf, 'Das Lippoldsberger Dichtertreffen', Göttinger Tageblatt, 2.7.1935, DLA - A: Grimm, Dichtertage - Zeitungsberichte, 1935-1936.

I1 8 Koch, '1936: Dichtertreffen bei Hans Grimm', p. 342. 
army, and tea and cake on sale for $40 \mathrm{Pf}$. in the afternoon, people could mingle more informally with the same writers. Bookstalls were set up to sell the works of the authors present, and others, allowing an opportunity for book signings and more general advertisement of their works. ${ }^{119}$

While the concert provided the focal point of the morning, the afternoon was devoted to literary pursuits with readings from selected writers and musical interludes provided by the musicians from Göttingen. In 1935, Rudolf Binding read his short story, Sankt Georgs Stellvertreter to great acclaim. ${ }^{120}$ The Göttinger Tageblatt reported:

The elements of Binding's narrative art underpinned the presentation: the wellbred economy of words, which nonetheless achieve the highest expressiveness, the unbreakable closeness of form [...], and the manful, knightly poise of the horseman. One can say nothing better about these evening hours than that Binding succeeded in welding the thousand-headed crowd of listeners, who listened in breathless silence, into a great community of listeners. A community formed from all social classes, from members of the Reichswehr, the SA, and school pupils, from students and agricultural labourers. ${ }^{121}$

The writers were part of the romance of the literature, something that was emphasised during these events, in accordance with völkisch ideology. The writer was not just an artist, but the mediator of the Volksseele and as such part of the spiritual drama of the literature. The readings gave the listeners, frequently referred to as 'readers' by reporters, an active role in the literary sphere, allowing them to participate in the same drama. Crossing class boundaries, they represented the Volksgemeinschaft, bound together in the moment by the literature of the Volk, read by the priests of the Volksseele.

In 1935, the first meeting in which the AOV was involved, the Lippoldsberg meetings were still a novelty. They nonetheless attracted the attention not only of the regional newspapers in Lower Saxony, but the press across Germany. Even the Völkischer Beobachter carried a short notice

I19 Schüddekopf, 'Das Lippoldsberger Dichtertreffen.'

I20 Rudolf Binding, 'Sankt Georgs Stellvertreter' in Legenden der Zeit (Frankfurt a/M: Rütten \& Loening, 1909), pp. 6I-I23.

I2I In Schüddekopf, 'Das Lippoldsberger Dichtertreffen.' 
of the event. It emphasized the musical aspects over the literary, which was presented as an informal, almost chance congregation of a number of writers, whose presence in Lippoldsberg happened to coincide with the concert. ${ }^{122}$ Illustrated journals like Germania also reported on the meeting in 1935 . Here Grimm was congratulated on his efforts, 'to pull art once again out of the racially foreign, solitary sphere of pure aesthetics and to root it once more in the Volk, from which in the end it comes, because only he who comes from the community of his Volk [... can be a true artist. ${ }^{123}$ The Frankfurter Zeitung, one of the more independent, liberal newspapers to survive in the Third Reich, also reported on the event, emphasizing the inter-class nature of those in attendance, and congratulating Binding on holding their attention. ${ }^{124}$

In many ways the meetings in the two following years, 1936 and 1937 , represented the heyday of the Lippoldsberger Dichtertreffen. Of these, 1936 was probably the most significant. While Hans Grimm's relationship with the Nazi state had already deteriorated - he was no longer a member of the governing board of the RSK, he was disillusioned with the progress of the Literature Academy, and problems for the Langen-Müller publishing house were looming on the horizon ${ }^{125}$ - the meetings at Lippoldsberg had not yet become a target for Goebbels. Instead, as the Deutsche Allgemeine Zeitung reported, the meeting's main purpose in 1936 appeared to lie in the justification, consolidation and development of the event. ${ }^{126}$ In 1936 the number of writers who attended increased. Alongside the veterans of the year before - Paul Alverdes, Rudolf G. Binding, Bruno Brehm and Moritz

I22 Völkischer Beobachter (Süddeutsche Ausgabe), No. 185, 3.7.1935, DLA - A: Grimm, Dichtertage - Zeitungsberichte 1935-1936.

I23 Germania, I935: undated newspaper cutting, DLA - A: Grimm, Dichtertage Zeitungsberichte, 1935-1936.

I24 Frankfurter Zeitung, 1935: undated newspaper cutting, DLA - A: Grimm, Dichtertage - Zeitungsberichte, 1935-1936.

I25 See below, pp. 297-307.

I26 Jürgen Schüddekopf, 'Lesestunde auf dem Klosterhof. Dichtertreffen bei Hans Grimm' in Deutsche Allgemeine Zeitung, 1.7.1936, DLA - A: Grimm, Dichtertage Zeitungsberichte, 1935-1936. 
Jahn - Friedrich Bischoff, Walter Julius Bloem, Hermann Claudius, Edwin Erich Dwinger, Georg Grabenhorst, Börries von Münchhausen, Uwe Lars Nobbe and Rudolf Alexander Schröder all accepted Grimm's invitation. Noticeably, among previous participants who were not present in 1936 were Ernst von Salomon and Joachim von der Goltz. In neither case, however, was absence an expression of disaffection; both were kept away by mundane concerns. The public Sunday followed the same pattern as in the previous year. Once again, the orchestra from Göttingen performed music from the seventeenth century, with a programme of works by Schein and Heinrich Schütz, both, it was emphasised, German composers. ${ }^{127}$

In 1936 , the literature was definitely in the foreground. In contrast to 1935, this time Grimm asked five writers to read from their work, providing the public not only with a more varied programme, but also giving them the chance to experience a larger number of well-known authors in person. The afternoon session therefore began with a ballad by Münchhausen, the 'Totspieler'. This was followed by two poems from Hermann Claudius, the 'Lumpenlegende' and his most famous piece, 'Wenn wir schreiten.' After a testimony to their friendship delivered by Grimm, Claudius ended with a final poem, 'Volk!' Rudolf Alexander Schröder also read a war poem, followed by a Christmas legend, before Friedrich Bischoff contributed three poems from his new volume, Schlesischer Psalter. To round the afternoon off, Binding took to the stage as he had a year before, this time reciting three poems on landscapes. He concluded the proceedings with one more work, 'Marsch der Jugend', described as a 'call to arms addressed to the German youth.' 28

In reflecting on the significance of the Lippoldsberger Dichtertreffen, commentators increasingly suggested that it represented the beginnings of a new German Dichterkreis. Such a suggestion was dangerous. The idea

I27 Börries von Münchhausen, 'Lippoldsberger Dichtertage', Deutscher Zukunft, Sunday 19th July 1936, p. 7, DLA - A: Grimm, Dichtertage - Zeitungsberichte, 1936-1936.

I28 Schüddekopf, 'Lesestunde auf dem Klosterhof. Dichtertreffen bei Hans Grimm.'; G.W. Pfeiffer, 'Lippoldsberger Fahrten. Erfurcht vor dem Ewigen und heiße Liebe zu unserer Heimat', Göttinger Nachrichten, No. 149, 29.6.1936, DLA - A: Grimm, Dichtertage - Zeitungsberichte, 1935-1936. 
of a new literary movement coming into being around Hans Grimm was potentially threatening to the Nazis' demand that cultural movements in the Third Reich be centred on the Party and the National Socialist movement. The Lippoldsberg meetings were increasingly perceived as a challenge by leading Nazis in the late 1930s, not least Goebbels. Rumours began to grow that Grimm was sowing the seeds of sedition among his guests.

The idea of a new literary movement did not come from Grimm himself, who, possibly learning from his disappointment with the Literature Academy, preferred to keep proceedings and relationships on a non-institutional level. Instead it was propagated in the press. On 30 th June 1936 , for example, the Göttinger Nachrichten ran an article entitled 'Dichtung aus nationaler Verantwortlichkeit. Ein neuer deutscher Dichterkreis um Hans Grimm, dem Lippoldsberger Rufer.' ${ }^{129}$ Dichterkreise, the article asserted, were characteristic in the history of German literature, particularly in moments of change. The article does not, however, comment on whether the circles were themselves agents of change, or a response to it. Instead it continues by suggesting that never before had a group of writers come together to form such a complete circle, stating: 'Here now, with the "Lippoldsberger Dichterkreis" it appears to us that streams of power flow together from different directions towards an ideal focal point: Literature out of national responsibility, literature out of the new ethos formed by the experience of war, literature which combines both: the great task and the great legacy. ${ }^{130}$ While the connection between landscape and tribe, the article goes on, had brought writers together in the various individual regions, and the large Nazi cultural events notwithstanding, nowhere in Germany did any single group or event represent the coming together of the German Geist more than in Lippoldsberg. As Germany became increasingly united under the Nazis, therefore, literature too was uniting across Germany. Grimm was given full credit for bringing the group together. ${ }^{131}$

I29 G.W. Pfeiffer, 'Dichtung aus nationaler Verantwortlichkeit. Ein neuer deutscher Dichterkreis um Hans Grimm, dem Lippoldsberger Rufer', Göttinger Nachrichten, 30.6.1936, DLA - A: Grimm, Dichtertage - Zeitungsberichte 1935-1936.

130 Ibid.

I3I Ibid. 
Such reports were unlikely to be welcomed by the Nazi hierarchy. Grimm's meetings attracted a greater and more enthusiastic public than officially organised cultural events. The involvement of the army, as well as local SS and $\mathrm{HJ}$ groups made it difficult to reject the Lippoldsberg events as being against the regime, and yet the Nazis had no control over them.

At the Wartburg Dichtertage in 1936, Blunck raised the subject of an article by Münchhausen about Lippoldsberg that appeared in Deutsche Zukunft on 19th July 1936 and was fiercely criticised in the Nazi Party controlled Wille und Macht on Ist August 1936. ${ }^{132}$ Blunck suggested that Lippoldsberg was a breeding ground for sedition against the Reich. Other Rosenritter agreed that this was certainly how the public viewed it. ${ }^{133}$ This was not the case. As the press reports showed, in general the public image of the Lippoldsberger Dichtertreffen was extremely positive right up to 1939. In no way were they perceived as counter to the spirit of the regime. The only negative coverage was in Nazi owned organs, reflecting the negative views held by the Party hierarchy. This was due to their inability to control either the attendance or the programme - Blunck for one never received an invitation from Grimm, which is unsurprising given the relationship of the two men in the I930s - and also possibly partly due to the fact that domination over the cultural sphere was already hotly contested and Grimm's success only made the arena more competitive for men like Rosenberg and Goebbels.

Addressing the matter, Münchhausen's diary recorded its author's public defence of the Lippoldsberger Dichtertreffen. The extract he sent to Grimm in January 1937 suggests he had enjoyed the event:

I answered that there could be no such talk. After all, large numbers of S.A. and S.S. men, army officers and non-commissioned officers, professors and students

I32 Börries von Münchhausen, 'Lippoldsberger Dichtertage,' p. 7, DLA - A: Grimm, Dichtertage - Zeitungsberichte, 1936-1936; 'Andenklich der Lippoldsberger Tagung', Wille und Macht, I.8.1936, DLA - A: Grimm, Dichtertage - Zeitungsberichte, 1935-1936.

I33 Excerpt from Münchhausen's Wartburg Tagebuch, sent to Grimm in a letter on 20.1.1937, DLA - A: Grimm, Münchhausen to Grimm. 
from Göttingen were all among the audience; among the writers, for example, was the Austrian party representative Nobbe and furthermore three English professors of literature, - all of these were in themselves clear evidence that no one among the participants would have been able to come onto such misguided thoughts. But apparently the organisation of public lectures by writers outside the N.S. Kulturgemeinde counts as insurgency [...]. There shall no longer be any joy other than that which has been officially sanctioned. ${ }^{134}$

Münchhausen continued by stating that as a result of the criticisms sparked off by Blunck's comment, he would not attend the Lippoldsberger Dichtertreffen again, wondering somewhat ironically how long association with Hans Grimm had been considered a crime. While he underlined his fundamental and solid support for Hitler's government, which, he said, had done more good in three years than any previous German government, he did also express in the diary his intention to withdraw from the Wartburg project. At sixty he felt too old to deal with criticism and he suggested that Blunck's comments had marred his otherwise very happy memories of the time he had spent at Lippoldsberg. While Blunck held back from outright criticism of Grimm, Münchhausen, whose loyalty was always stronger than his good judgement, was torn between his two friends. ${ }^{135}$

The discussion at the Wartburg mirrored a growing suspicion in party circles of the Lippoldsberger Dichtertreffen. Grimm did not react directly to Münch hausen's letter. He did, however, decide that contrary to his original plans he would hold a meeting in Lippoldsberg in 1937. This was partly a response to growing criticism and partly a response to several negative experiences whilst on a lecture tour in London, which convinced him of the need for such an event. ${ }^{136}$ The last was also the reason for the larger number of foreign professors and intellectuals invited in 1937. Therefore, alongside a long list of German writers - Alverdes, Binding, Bischoff, Brehm, Carossa, Claudius, Dwinger, Fechter, Grabenhorst, Heinz, Jahn, v. Mechow, Schröder, Winnig, Zillich - he invited Professor Heusler from

134 Ibid.

I35 Ibid.

I36 Grimm to Salomon, 16.2.1937, DLA: Nachlaß Grimm, Grimm to Salomon, 19341958; Grimm to Binding, 24.2.1937, DLA - A: Grimm, Grimm to Binding, 1936-1937. 
New York, Professor Bennett from Cambridge, Professor Fiedler from Oxford and Professor Gabetti from Rome, all of them specialists in German studies in their home countries. ${ }^{137}$

The English writer Edmund Blunden was also present. In an article he contributed to German Life and Letters, he described the experience, comparing it to the Glyndebourne opera. Blunden's description of the event captures its informal atmosphere, characterised by the status of the writers as Grimm's guests. He also showed appreciation for the conservative approach to literature adopted by the völkisch-nationalist writers he met:

It was the naturalness of the German feeling for rhyme and metre, for pure ballad verse - the firmness of the popular tradition, uniting the poetic Germany of Uhland's day with that of 1937 . The experiments in unfamiliar form and rhythm which modern times have seen in Germany have not, I gather, affected this general capacity for being made happy with simple stanzas and symmetrical versification. ${ }^{138}$

This was exactly the response Grimm was looking for. By inviting visitors from abroad to join his guests in Lippoldsberg, he addressed one of his biggest concerns: the reputation of German literature abroad. Here he was in a good position to build not only on his own experiences in Britain and Africa, and his work in the Foreign Ministry during the First World War, but also his extensive network of contacts around the world. Well aware of the fact that many of Germany's most prominent and gifted writers had gone into exile since 1933, often publicly denouncing the Nazi regime, Grimm had long championed the cause of German literature abroad. During the I930s he undertook several lecture tours to Britain, America, and even Brazil. ${ }^{139}$ Through these trips and the international visitors to Lippoldsberg, he probably achieved more than Blunck in this area, despite the fact that this

I37 Undated article in Literatur (1937), DLA: Nachlaß Grimm, Dichtertage Zeitungsberichte, 1937 .

138 Edmund Blunden, 'The Klosterhaus Readings 1937', German Life and Letters, vol. 2, no. I (1937), pp. 33-38, DLA - A: Grimm, Dichtertreffen - Zeitungsberichte, 1937.

139 Grimm to Salomon, 22.11.1936, DLA - A: Grimm, Grimm to Salomon, 1934-1958; Grimm to President of the Deutsche Akademie, München, 8th January 1937, DLA A: Grimm. 
became the latter's particular concern following his dismissal as President of the RSK in 1935 .

In spite of its continued success with the public and the writers who participated, by 1938 Grimm was under pressure from various corners regarding the Lippoldsberger Dichtertreffen. The authorities were clear in their antipathy towards the events. ${ }^{140}$ In addition, in his own life changes were occurring that meant that he was gradually pulling away from public activity. Disillusioned with the Literature Academy and the situation regarding the Langen-Müller Verlag, he increasingly devoted his energy to his writing. His novel on German-British relations, Heynade und England, had been in the pipeline for most of the r930s, but neglected due to Grimm's public and political activities. By the beginning of 1938 he had also decided to move away from Lippoldsberg. His correspondence details various journeys undertaken to East Prussia and parts of Austria to look at estates he might buy. ${ }^{141}$ While the plan was never fulfilled on account of the outbreak of war in 1939, it was the subject of a number of the newspaper commentaries on the Lippoldsberger Dichtertreffen in 1938. As Grimm read extracts from Volk obne Raum to the gathered public, the Kölnische Volkszeitung discussed the collective sorrow at the thought that he would leave the landscape that had been so central to his work, and that he had made familiar to readers far beyond the region. ${ }^{142}$

The meeting in 1938 was best remembered, however, as the last public appearance of Rudolf Binding, who died only weeks after the event. Further poignancy was added by the fact that Grimm had requested his guests this year to read something autobiographical at the meeting, in response to which Binding selected the passage from his autobiography, Erlebtes Leben, in which he described the death of his father. ${ }^{143}$ Binding's sudden

I40 Memorandum from Bischoff to Ihde in the RSK, 27.7.1938, B.Arch.R56V-77; Letter from Hanns Johst's secretary, R.Hauff, to Frl. Schneider in RSK, 2.7.1938, B.Arch $\mathrm{R}_{5} 6 \mathrm{~V}-77$.

I4I Grimm to Binding, 6.4.1938, DLA - A: Grimm, Grimm to Binding, 1938.

I42 'Das Dichtertreffen bei Hans Grimm', Kölnische Volkszeitung, No. I83, 7.7.1938, p. 4, DLA - A: Grimm, Dichtertage - Zeitungsberichte, 1938-1939.

I43 Rudolf Binding, Erlebtes Leben, pp. 276-293. 
death following a routine operation provided an opportunity to invest his performance with symbolic significance in the press that further added to the interest in the event as a whole. ${ }^{144}$ Even as Grimm was distancing himself from his creation, the public was more than ever determined to maintain this annual event. ${ }^{145}$

Given Grimm's own decision to withdraw from the Lippoldsberger Dichtertreffen, the fact that they survived, albeit in rather curtailed form, until 1939 and were only really stopped by the outbreak of the Second World War, owed much to the opposition of the Nazi leadership itself. Goebbels' determination to close the event down served to fan the flames of Grimm's determination to keep it going. By 1938, the authorities were clear in their antipathy towards the Lippoldsberger Dichtertage. ${ }^{146}$ On 5 th August 1938, Goebbels noted in his diary: 'The writer Hans Grimm is staging a writers' meeting with a somewhat negative tendency. I will now examine this meeting rather more closely. I will not tolerate a confessional front among the writers. ${ }^{147}$

Following attempts to evade a personal meeting, giving bad health and work commitments as his reasons, Grimm was finally forced to attend an interview with Goebbels on 2nd December $1938 .{ }^{148}$ The conversation between the writer and the Minister for Propaganda lasted two hours, during which the latter listed Grimm's sins. In addition to the Lippoldsberger Dichtertreffen, Grimm was also criticised for his refusal to attend Party events and conferences, and for the letter he had written to Wilhelm Frick

I44 For example: 'Bindings Abschied - Eine Erinnerung', Hannoversches Kurier, Friday IIth November 1938, DLA - A: Grimm, Dichtertage - Zeitungsberichte, I938-I939.

I45 'Das Dichtertreffen bei Hans Grimm', Kölnische Volkszeitung, No. 183, 7.7.1938, p. 4, DLA - A: Grimm, Dichtertage - Zeitungsberichte, 1938-1939.

I46 Memorandum from Bischoff to Ihde in the RSK, 27.7.1938, B.Arch.R56V-77; Letter from Hanns Johst's secretary, R.Hauff, to Frl. Schneider in RSK, 2.7.1938, B.Arch R56V-77.

I47 Fröhlich (ed.), Die Tagebücher von Joseph Goebbels, part I., vol. 3, 5.8.1938, p. 500.

I48 Letter from Grimm's secretary to Reichsministerium für Volksaufklärung und Propaganda, June 1938; two letters from Grimm's secretary to Herrn Jaensch, Reichsministerium für Volksauflärung und Propaganda, I6th 17th November 1938; two letters from Grimm to Goebbels, 2oth November 1938, all in DLA - A: Grimm - Grimm to Deutschland, Deutsches Reich, Reichsministerium für Volksaufklärung und Propaganda, 1931-1939. 
on 4th April 1936. ${ }^{149}$ Here he had criticised the way an openly oppositional resident of Lippoldsberg had been treated by various Party institutions and functionaries after he voted against the re-militarisation of the Rhineland in a plebiscite in March 1936. Referring to the fate of Ernst Wiechert, Goebbels then threatened Grimm with imprisonment: 'Dr. Grimm, I send people to concentration camps for four months. If I send them there a second time, they never come out. ${ }^{150}$ Grimm responded by distancing himself from the comparison with Wiechert and reminded Goebbels that he was openly in favour of National Socialism, but that he remained consciously outside the Party. While the interview ended with further threats from Goebbels, Grimm remained unrepentant. ${ }^{151}$ He still refused to participate in the Weimarer Dichtertage. The refusal of the organiser of Germany's most spontaneously popular annual literary event to support the government's official equivalent was bound to send a negative message to the German public. Only the outbreak of the Second World War allowed the rift between him and the Propaganda Minister to be at least partially repaired. His activities during the War were focused largely on his German-English novel. Grimm viewed this as an essential contribution to the national cause, providing insight into the longstanding difficulties in the relationship between the two nations. He believed the War to be a result of the mistaken view among the British that Germany's desire to join the ranks of great powers from the late nineteenth century was a threat, a perspective that was also fundamental to his response to the post-war years. ${ }^{152}$

I49 Fröhlich (ed.), Die Tagebücher von Joseph Goebbels, Part I., Volume 3, 20.II.1938, pp. 54I-542; see discussion of Grimm's correspondence with Frick, Chapter 2, pp. $153-156$.

I50 Hans Grimm, minutes of meeting with Joseph Goebbels on ist December 1938, written from memory during the night of Ist - 2nd December 1938 and witnessed by the lawyer Dr. Pondorf, DLA - A: Grimm - Gedächtnisprotokoll der Unterredung mit Joseph Goebbels am 2.12.1938; see also Barbian, Literaturpolitik, p. 407.

I5I Grimm, minutes of meeting with Joseph Goebbels on ist December 1938; see also Barbian, Literaturpolitik, pp. 406-409.

I52 See, for example, Grimm to Hadamovsky at RMVP, 24.I.I940, DLA - A: Grimm, Grimm to Deutschland, Deutsches Reich, Reichsministerium für Volksaufklärung 
The final Lippoldsberger Dichtertreffen held during the Third Reich, in July 1939, was organised not by Grimm, but by the Göttinger Akademische Orchester-Vereinigung. All the same, Grimm was not only present, but as usual the meeting was held at his home. In many ways, therefore, it was quite a dangerous undertaking. In addition to Grimm, Rudolf Alexander Schröder, Moritz Jahn, August Winnig and Hermann Claudius were also present. In newspaper reports, however, this last meeting was mainly characterised by the gap left by Binding. ${ }^{153}$ It is difficult to ascertain from Grimm's correspondence exactly what his own thoughts on this meeting were. With the death of Binding, one his closest professional confidants had gone. Following the dismissal of Gustav Pezold from the Langen-Müller Verlag, ${ }^{154}$ he was no longer on speaking terms with Kolbenheyer, and the two men only resumed their correspondence in 1946 when circumstances in Germany had changed and the old guard among völkisch-nationalist writers felt the need to hold together. ${ }^{155}$

By 1939, the old Munich alliance had also largely dissolved. Having given up on the Literature Academy, its members, all of whom were either in or rapidly approaching old age, had largely turned inwards towards their work and individual projects. Grimm too, it is true, was increasingly concerned with his work on German-British relations. His endeavours were only interrupted by the outbreak of the Second World War, which claimed his attention and saw a renewal of his popularity with the Nazi leadership. The latter welcomed the anti-English standpoint of his novel, Heynade und England, and encouraged him to work for its swift completion. In the end he did not achieve this, but nonetheless, in 1940 Goebbels' offices also

und Propaganda, 1940-1944. This correspondence also contains discussion of a possible English translation of Volk ohne Raum, which Grimm also viewed as necessary for the national cause.

I53 'Der 6. Lippoldsberger Dichtertag. Gedenkstunde für R.G. Binding' in Deutsche Allgemeine Zeitung, No. 315/16, 5.7.1939, DLA - A: Grimm, Dichtertage Zeitungsberichte, 1938-1939.

I54 See below, pp. 300-306.

I55 Grimm to Kolbenheyer, I2.9.1946, DLA - A: Grimm, Grimm to Kolbenheyer, 1933-1959. 
promoted an American translation of Volk ohne Raum, with which it was hoped to counter the negative effect of anti-Nazi statements and publications by German writers in exile. ${ }^{156}$ The Second World War also claimed the attention of his erstwhile colleagues in the Munich Consensus, giving them a clear focus for their nationalism. They became involved in the war effort, although as elderly men there were by this stage significant limits to the active work they could carry out.

Like many projects in which Grimm and his völkisch-nationalist colleagues were involved, the Lippoldsberger Dichtertreffen eventually ground to a halt in the Third Reich, only to be resumed again by Grimm after the War. Nonetheless, their impact was widespread and significant, probably doing more to spread the völkisch message in the r930s than any other single initiative. Moreover, while outside influences were allowed on the public days, in the form of contributions from various groups from the region, lending the occasions a co-operative character, Grimm took great care to ensure that the private time at Lippoldsberg each year remained free of outside and official influences. His greatest achievement with the Lippoldsberger Dichtertreffen was ensuring that they remained entirely free of interference from the Nazi government.

The public days played their part in this. In involving the nearby University of Göttingen, as well as SA, SS and Reichswehr units stationed in the vicinity, and in allowing the public to come and enjoy a day of music, literature and relaxation in the idyllic surroundings of Lippoldsberg, and finally by encouraging newspaper coverage of the events, Grimm gained a degree of protection against Goebbels' attempts to end the meetings. The latter was unable to force Grimm to give them up without damaging his own public image. Paradoxically, Grimm's credentials not only as a loyal German nationalist, but also as a supporter and contributor to the regime, were partly gained thanks to Goebbels' own efforts to publicise Grimm's support for the Nazis' endeavours in the early 1930s. In the public eye, he represented much of what the Third Reich meant to many ordinary Germans. 


\section{The Lippoldsberger Dichtertage and the Survival of Völkisch-Nationalism after 1945}

The unpopularity of the Lippoldsberger Dichtertage with the Nazi government was highlighted by Grimm after the war, partly to distance himself from association with the Nazi regime. He revived the meetings in August 1949. The first post-war meeting, presented to the public as a dörfliche Goethefeier, marked the 2ooth anniversary of Goethe's birth. Its success and the popularity of the event thereafter is an example of the extent to which völkisch-nationalist writers were able to continue their careers after 1945, shedding light on the nature of their post-war work and their position in the political and cultural spheres of West Germany in the I950s. The large number of newspaper articles that appeared across Germany, and even abroad, show widespread public awareness of the events. They were not, however, uncontroversial. The press responded with widely varying opinions, a contrast with the almost universally favourable reports of the I930s. Nonetheless, this probably reflected increased freedom of the press as much as changed public consciousness; indeed thousands of people continued to turn up each year to hear Grimm's literary guests read from their works.

Grimm insisted on the continuity between the Lippoldsberger Dichtertage in the 1950s and those of the 1930s, putting a gloss on the idea that the event had been born as a result of his concern to maintain the independence of German literature in the Third Reich. ${ }^{157}$ He supported his position with reference to the problems he had experienced with Goebbels in the late 1930 and an emphasis on his refusal to join the NSDAP.

On the other hand, he had always defined himself as a political writer and in the course of the 1950s the Lippoldsberger Dichtertage increasingly emphasised political rather than literary independence. Whereas Grimm

I57 Die Lippoldsberger Dichtertage, pamphlet published by the Klosterhaus-Verlag, Lippoldsberg for the Dichtertag 1960, DLA - A: Grimm, Lippoldsberger Dichtertage. Zugehörige Materialien, 1960-198I. 
had previously fought to ensure that 'German' literature was elevated above Nazi propaganda, now he was concerned with the maintenance of the 'German' spirit in the chaotic and uncertain climate of the post-war years. He sought to counter the perceived dominance of a new political and cultural elite supported by the occupying powers. This elite was composed in large degree of those returning from exile and victims of Nazi racial and political persecution. The former were unpopular for having left while others had stayed and suffered the hardships of war; the latter represented living reminders of Nazi atrocities many preferred to forget. ${ }^{158}$ As far as Grimm was concerned, a third influential category was represented by those who had been involved in the resistance during the Third Reich. Their efforts were seen by many to have not only undermined the regime, but the nation, contributing to Germany's defeat and amounting to treason, an outright betrayal of the German Fatherland. ${ }^{159}$

In spite of his ambivalence towards the Nazi regime Grimm considered the downfall of the Third Reich a retrograde development in German history, exacerbated by the 'distorted' worldview that determined the actions of the Western Allies after May 1945. While he rejected the label 'National Socialist', he made it clear in a letter to the widow of the Nazi Foreign Minister, Joachim von Ribbentrop, in February 195 I that his intention was to defend the politics of Hitler's regime. ${ }^{160}$ The conditions in Germany after the Second World War lent new urgency to his völkisch crusade, evident also in his writing after 1945: his efforts to complete the epic novel he had been working on since the I930s were superseded by his desire to

I58 Detlef Garbe, "Äußerliche Abkehr, Erinnerungsverweigerung und "Vergangenheitsbewältigung”: Der Umgang mit dem Nationalsozialismus in der frühen Bundesrepublik' in Axel Schildt and Arnold Sywottek (eds), Modernisierung im Wiederaufbau: Die westdeutsche Gesellschaft der soer Jahre (Bonn: Dietz, 1993), pp. 698-699.

I59 This is particularly clear, for example, in Grimm's correspondence with Annelies von Ribbentrop throughout the r950s - DLA - A: Grimm, Grimm to Annelies von Ribbentrop, 1950-I959; DLA - A: Grimm, Annelies von Ribbentrop to Grimm, 1950-1959.

I60 Grimm to Annelies von Ribbentrop, I2. Februar 1951, DLA - A: Grimm, Grimm to Annelies von Ribbentrop, 1950-1959. 
address the problems he identified in domestic and international affairs. His post-war political analyses, particularly the Erzbischofschrift (1950) and Warum - Woher - Aber Wohin? (1954), both of which gained considerable attention, represented Grimm's response to the recent past. ${ }^{161}$

As Detlef Garbe has observed, the efforts to confront the Nazi past in the immediate post-war period were not carried out with broad popular support, but instead antagonised many Germans. ${ }^{162}$ The Lippoldsberger Dichtertage provided visitors with an opportunity to take refuge from the uncomfortable demands of the post-Nazi present, while they helped the writers involved reaffirm their ideological position, drawing on völkisch ideas to make sense of Germany's defeat and the post-war political and cultural developments encouraged by the allies and the new Federal government. The events allowed the reestablishment of a live relationship between völkisch writers and representatives of the German Volk. The meetings provided not only a context in which völkisch writers could communicate their ideas, but also a context for collective endorsement of their political position, presented as an alternative to both the new West German parliamentary democracy and the socialism of the GDR.

Alongside several well-known, popular names and veterans of the Dichtertage of the 1930s, a number of new figures appeared behind the lectern in Lippoldsberg after the War. In 1949, Grimm was joined by his old friend, the poet Hermann Claudius, as well as Will Vesper, a new face at the Lippoldsberger Dichtertage, but a prominent figure in the literary sphere of the Third Reich, not least as the editor of Die Neue Literatur. ${ }^{163}$ In the years that followed, readings from Heimat poets like Moritz Jahn were complemented by the reminiscences of military men, for example

16I Grimm, Hans, Die Erzbischofschrift: Antwort eines Deutschen (Göttingen, 1950); Warum - Woher - Aber wohin? Vor, unter und nach der geschichtlichen Erscheinung Hitler (Lippoldsberg, 1954).

I62 Detlef Garbe, 'Äußerliche Abkehr', pp. 698-699.

I63 Gisela Berglund, Der Kampf um den Leser im Dritten Reich: Die Literaturpolitik der 'Neuen Literatur' (Will Vesper) und der 'Nationalsozialistischen Monatshefte' (Worms: Heintz, 1980); Sarkowicz and Mentzer, Literatur in Nazi-Deutschland., pp. 340-342. 
Hans-Ulrich Rudel, and political commentaries delivered by nationalist publicists like Heinz Mahnke. Particularly prominent on the programme each year were eulogies to Germany's lost territories delivered by the likes of the Sudeten-German Vertriebene Wilhelm Pleyer and Hans Venatier, or the East Prussian Renate von Fischer, to say nothing of the poems of Ursel Peter, dedicated to those who had sacrificed their homes or even their lives for Germany. ${ }^{164}$

Grimm's skill lay in his ability to join the individual writers together in the name of the German cause for which he had spent his life fighting, and to link this cause to the challenges large sectors of the population faced in the immediate post-war years. The Dichtertage helped Grimm and his colleagues gain new currency in the post-war political and cultural climate by linking their ideological programme to the immediate experiences of the audience.

Grimm's concerns in these years were clear in his Dörfliche Goetherede in 1949: Germany's position in the world and the ongoing suffering experienced by her population as a result of the war and defeat at the hands of the Allies. These included not only the treatment of Germany after the War, but also the conditions of those expelled from the former Eastern territories. The material destruction of the German homeland was manifold, caused by the loss of large territories and the bombing raids on her cities. Furthermore, the Germans were no longer the free masters of what was left of their country; they had been subjected to deliberate 'Seelentotschlag' by the propaganda of foreign opinion-makers. Thus, far from accepting the idea of 'collective guilt', as far as Grimm was concerned the Germans had become the scapegoats of history, prevented over centuries from unfolding their full potential by jealous neighbours determined to limit their development. The contributions made by the German Volk to humankind, evident in Goethe's works, had been forgotten. Rejecting the political structures established after 1945 in both East and West Germany, Grimm's

I64 Full lists of participants are available, DLA - A: Grimm / Lippoldsberger Dichtertage, Konv. Teilnehmerlisten 1934-1939 / 1958-1959; see also Die Lippoldsberger Dichtertage, pamphlet published by the Klosterhaus-Verlag, Lippoldsberg for the Dichtertag 1960, DLA - A: Grimm / Lippoldsberger Dichtertage, Zugehörige Materialien, 1960-I98I. 
concern for the future of the German Volk was reflected in his emphasis on the importance of German youth, and his call for the unification of Europe along völkisch lines. This would preserve European civilisation in the face of foreign threats coming from the USA and the USSR, creating a third superpower. ${ }^{165}$

Establishing what would become a common feature of future meetings, in 1949 Grimm also included a 'greeting' to those who had died or suffered in the previous ten years, calling on his listeners to bow their heads to those who had gone un-thanked for the sacrifices they had made for Germany. The formal remembrance of dead fellows became a core element of the meetings held in the decades that followed. Grimm himself joined their ranks in 1959, after which a ceremony at his grave was conducted each year. In addition, the 'sacrifices' of those who had lost their homes through Vertreibung or the wartime destruction of German cities were also remembered. In this way, the individual experiences of Germans during and after the War were united in a collective spirit of sacrifice for the Volk. ${ }^{166}$

While the content of the events laid bare the political position of the writers involved, Grimm consciously sought to limit undue public controversy, particularly in the early i950s. He therefore sought a balance between the true representation of the völkisch ideology that was fundamental to his understanding of literature, as well as to the character of the Lippoldsberger Dichtertage, and his desire to avoid controversy. In 1950 and 195I Grimm stuck to readings from his South African tales, avoiding overt political provocation, although for many the colonial and racist agenda of these stories would have been clear. A more explicit politial agenda was, however, evident in 1952 with Karl Kaltwasser's lecture 'Vom Amt des Dichters im Volk.' ${ }^{167}$ This question of the writer's

I65 Hans Grimm, 'Eine dörfliche Goethe-Rede' in Erkenntnisse und Bekenntnisse (Göttingen: Göttinger Verlags-Anstalt, 1955), pp. 38-52.

I66 Die Lippoldsberger Dichtertage, pamphlet published by the Klosterhaus-Verlag, Lippoldsberg for the Dichtertag 1960, DLA - A: Grimm - Lippoldsberger Dichtertage. Zugehörige Materialien, 1960-198I.

I67 'Vom Amt des Dichters im Volk. Dichter lasen in Lippoldsberg', Göttinger Tageblatt, I2.8.1952 in DLA - A: Grimm, Dichtertage, Zeitungsberichte, I95I-I952. 
role in society, which had long occupied völkisch-nationalist intellectuals, was picked up again at the Lippoldsberger Dichtertage in subsequent years. Grimm introduced the proceedings in 1953 by emphasising that the writers had come together as a result of their concern with more than finding solutions to literary problems; they were gathered because of their common sense of obligation to the German whole. ${ }^{168}$ At this meeting, the young Heinz Mahnke presented a perspective from the younger generation of nationalists who had grown up and been educated in the Third Reich. Having fought in the Second World War, they were, Mahnke insisted, determined to protect and nurture German consciousness in literature and poetry. Mahnke had been a volunteer in the Waffen SS under the Nazis and after the War became a member of the Sozialistische Reichspartei (SRP), banned in the Federal Republic in 1952. He later functioned as a nationalist publicist and joined the right-wing Nationaldemokratische Partei Deutschlands (NPD). On I4th July 1953, the Fulda-Bote, the Beraer Zeitung and the Rotenburger Tageblatt, as well as the Hessische Nachrichten, all carried a syndicated article praising his presentation in Lippoldsberg. ${ }^{169}$ In 1954, Grimm followed up the theme of the previous year with a lecture, 'Die Aufgabe und Verantwortung des Dichters in unserer Zeit', which he also delivered on several lecture tours in Germany in the course of this year. ${ }^{170}$

While Grimm publicly played down the political nature of the Lippoldsberg meetings, in private he was quite clear that the opposite was the case. His emphasis on the German writer rooted in the Volk had its genesis in völkisch-nationalism as a political ideology in which authority and legitimacy were not established on institutional foundations

I68 'Auch Jugend kam zu Hans Grimm. Dichtertreffen in Lippoldsberg fand ein starkes Echo', Kasseler Post, undated clipping from 1953, DLA - A: Grimm, Dichtertage, Zeitungsberichte, 1953-1954.

I69 'Im Klosterhaus zu Lippoldsberg', Hessische Nachriften, Fulda-Bote, Beraer Zeitung, Rotenburger Tageblatt, I 4.7.1953, DLA - A: Grimm, DIchtertage, Zeitungsberichte, 1953-1954.

I70 The following year it was published in his collection of essays, Erkenntnisse und Bekenntnisse (Göttingen, 1955). 
or constitutional systems, but came directly from the $V o l k .{ }^{171}$ In this spirit, the meetings sought to spread a message of fundamental social renewal along nationalist lines. His position was shared by the writers who attended the post-war Dichtertage. Nonetheless, association with Grimm was not always perceived as advantageous and a letter in 1954 shows that he was conscious of the precarious nature of his situation. On 8th February, he asked the writer Wilhelm Pleyer whether he would be prepared in theory to attend a meeting, noting that: 'some authors are marked by coming here. Such agitation, fully without purpose or sense, was already underway before the "Erzbischofschrift", where emigrants targeted a few well-known names. After the "Erzbischofschrift" those members of society with dirt on their shoes joined the attack. ${ }^{172}$ The friendly, mutually supportive correspondence between the two writers up to Grimm's death in 1959, as well as Pleyer's regular attendance at the Dichtertage each year from 1958 show that he had no reservations about association with Grimm. Similarly, Wilhelm Pleyer's fellow expellee from Czechoslovakia, Hans Venatier, displayed no qualms about attending, in spite of the fact that he was twice required to justify his presence before committees of the government in RhinelandPalatinate in the second half of the 1950s. ${ }^{173}$

In spite of his desire to avoid criticism in 1956, by the end of the decade Grimm's sense of urgency after ten years of perceived degeneration in West Germany meant he was prepared to be more provocative. As the Lippoldsberger Dichtertag became increasingly political in the post-war years, Grimm also relinquished his old demand that the writers present should represent the zenith of German literary achievement. Instead a 'national' attitude that expressed their dedication to the German Volk became the only qualification for participation.

I7I See, for example, Hans Grimm to Hans Venatier, 22.6.1956, DLA - A: Grimm, Grimm to Venatier, 1932-1958.

I72 Hans Grimm to Wilhelm Pleyer, 8.2.1954, DLA - A: Pleyer - Grimm to Pleyer, 1947-1959.

173 Hans Grimm to Hans Venatier, 22.6.1956; 4.7.1956, DLA - A: Grimm, Grimm to Venatier, 1932-1958; Hans Venatier to Hans Grimm, 8.7.1956 in DLA - A: Grimm, Venatier to Grimm, 1932-1958. 
The changing nature of the Dichtertage was already reflected in some reviews of the event in $195 \mathrm{I}$. The Deister-und Weserzeitung was compelled to admit that, while Grimm, still a respected figure, could not be blamed for Germany's problems, he appeared to have lost his sense of diplomacy and the wisdom and fairness for which he had always been esteemed. ${ }^{174}$ It praised his engagement for all those who were suffering 'nur weil sie Deutsche sind', noting that many fell into this category, not least in connection with the Nuremberg trials. The journalist felt, however, that it was not appropriate, for Grimm to describe the inmates of Spandau prison ${ }^{175}$ as martyrs of the German Volk in his welcome address, and to follow this with a rendition of the Andreas-Hofer-Lied by the Lippoldsberg choral society. This served to destroy the distance that should be established between older German history and the shameful legacy of the twelve-year Nazi regime. Anyone who, like Grimm, was prepared to excuse the 'agonising' practices of this regime as 'unavoidable cruelty' and part of a 'process of purification' was clearly unaware of his own actions in the new post-war context. ${ }^{176}$

Nonetheless, the same article went on to comment positively on the readings of Hermann Claudius and Moritz Jahn, both described as 'masters of self-recitation', as well as Georg Grabenhorst's 'boys' tale 'Ruhig Blut, Old Shatterhand!'. August Hinrichs' readings from his Swinskomödie and a 'charming' low German poem were also praised. Little was said, on the other hand, about Hans Grimm's own story of the 'singende Werker', and humorous suggestions of ways to avoid war from Will Vesper were lost on the journalist. Most significantly, perhaps, Renate von Fischer's three verses about the 'catastrophe of East Prussia' undeniably represented, according to the newspaper, true, deep-felt experience, had little to do with poetry. This served to strengthen 'erst recht unsere Befürchtung, daß in Lippoldsberg

174 Deister-und Weserzeitung - Heimatzeitung für das mittlere Wesergebiet und die angrenzenden Landesteile, I6th July I95I, p. 2.

175 Grimm is referring here to the seven former Nazi leaders serving sentences in Spandau: Baldur von Schirach, Karl Dönitz, Konstantin Freiherr von Neurath, Erich Raeder, Albert Speer, Walther Frank, Rudof Hess.

${ }_{17} 6$ Deister-und Weserzeitung - Heimatzeitung für das mittlere Wesergebiet und die angrenzenden Landesteile, I6th July I95I, p. 2. 
zunehmend immer mehr Wert auf Gesinnungen, und weniger Gewicht auf die dichterischen Fähigkeiten gelegt werde. ${ }^{177}$

In 1953 a similarly mixed tone was evident in the centrist Hessische Nachrichten, which discussed the meeting in terms reminiscent of the idyllic descriptions of the events of many of the pre-war commentaries, often written by the same journalists who later reviewed the post-war meetings: 'The midday sun pushed its way over the high gables into the courtyard, a mild wind played with the vines on the timbers of the fine old convent walls and with the grey hair of writers in front of a thousand-headed [... audience. ${ }^{178}$ Nonetheless, the article expressed a clear sense of disappointment, suggesting that the readings in 1953 had not been of the same literary quality as those at the pre-war meetings. Similarly, the following year the Hannoversche Allgemeine Zeitung threw a 'besorgter Blick nach Lippoldsberg. It complimented Moritz Jahn and praised Hans Grimm's speech on 'Die Aufgabe und Verantwortung des Dichters in unserer Zeit', but expressed doubts about the ability of the other readers present to live up to Grimm's vision: 'The magnificent, eternally true has, in Grimm's opinion, long been said. The masters of the past all lived, as he stated, in a formed [...] time. Today, in an unformed time, it is the task of the writers to highlight the current confusion using artistic methods and to break through false tattle - always conscious of their responsibility for a united Europe. ${ }^{179}$ The situation in Lippoldsberg reflected the problems in Germany's post-war cultural life, the article concluded, suggesting a continued desire for leadership of the kind to which Germans were accustomed under Hitler. None had yet emerged who were able to redefine the inner existence of the nation, which was still divided nine years after the War and lacking clear political direction from above. Serious concern, the journalist maintained, was reflected in the faces of at least some of those who had

177 Ibid., p. 2

178 Hessische Nachrichten, I4.7.53, DLA - A: Grimm, Dichtertage, Zeitungsberichte, 1953-1954.

179 Dr. Rudolf Lange, 'Besorgter Blick nach Lippoldsberg', Hannoversche Allgemeine Zeitung, undated clipping from 1954, DLA - A: Grimm, Dichtertage, Zeitungsberichte, 1953-1954. 
gathered in the cloister courtyard, among whom were a number who would have remembered the days before the War when 'great' writers such as Rudolf G. Binding, Börries von Münchhausen, Hans Carossa and Rudolf Alexander Schröder had stood at the lectern. ${ }^{180}$

On the other hand, there were also a large number of purely positive reports of the meetings, suggesting that for many they continued to represent something on the level of a village fete or cultural festival. Reporting the visit of 'Warburger Literaturfreunde' to the Dichtertag in I95I, the Freie Presse in Bielefeld, for example, adopted an unreflective attitude towards the events, enjoying the Low German theme of the meeting that year. ${ }^{181}$ In 1952, the Kasseler Post also reported very positively on the Dichtertag: 'The thousand guests heartily thanked the men who had taken them out of their everyday lives for three hours. ${ }^{182}$ Similarly, the Göttinger Tageblatt, which had followed the events closely in the I930s, presented an uncritical commentary on the proceedings of that year. ${ }^{183}$

The enthusiasm for the Lippoldsberger Dichtertage in local and regional newspapers, in particular, suggests that their appeal reached beyond the circles of the extreme right. Estimates of the size of the public that attended the Goethe celebrations in 1949 varied in the press, but most newspapers spoke in terms of thousands, with 4000 a frequently cited figure. ${ }^{184}$ Moreover, the Dichtertage continued to attract large audiences throughout the r950s. Writing to Prof. Heuser at Columbia University in 1953, Grimm reported

I80 Ibid. A similar concern is also expressed in a report by the Freie NachrichtenBüro on the Lippoldsberger Dichtertag, 23.7.1955, DLA - A: Grimm, Dichtertage, Zeitungsberichte, 1955-1956.

I8I Freie Presse, Nr. 164, Dienstag, 17. Juli 1951.

182 Kasseler Post, I1.08.1952.

I83 'Vom Amt des Dichters im Volk - Dichterlesen in Lippoldsberg', Göttinger Tageblatt, Dienstag, I2. August 1952.

I84 See among others 'Eine dörfliche Goethe-Feier bei Hans Grimm' in the rightwing Deutsche Volkszeitung, undated clipping, 1949; 'Dörfliche Goethefeier', Weser Nachrichten, I6.8 1949; 'Dörfliche Goethefeier bei Hans Grimm', Niedersächsische Landbote, 28.8.1949: All in DLA - A: Grimm, Dichtertage, Zeitungsberichte, I949-1950. 
that 2,600 people had been present for the readings; in a later letter, he reported again that over 2,000 people had turned up in $1957 .{ }^{185}$

As far as it is possible to judge, photographs of the events in the r950s support Grimm's estimates, showing the public packed into the convent yard each year. ${ }^{186}$ And the presence of large crowds is also generally supported by the newspaper and magazine reports, although here the exact figures vary. There are a number of possible reasons for this. In a number of cases it is possible to assume that the figures cited also reflected the political weight given to the meetings. A paradox is evident in the responses of left-wing and liberal commentators in particular. Some played down the size of the meetings, presumably seeking to downplay the continued significance of Grimm and his völkisch colleagues. Others built up the ongoing threat of the right by emphasising a high number of visitors. A left-wing schoolteacher from Göttingen who criticised the event in the student magazine Impuls suggested that 5,000 people had been present in 1949, expressing concern that the Lippoldsberger Dichtertage were attracting large numbers of youth in particular. Towards the other end of the spectrum, the Kasseler Zeitung suggested an attendance of $1,500 .{ }^{187}$ In general, right-wing and local newspapers were more matter of fact about the numbers than their left-wing counterparts. Their tendency to cite figures that corresponded to those of the pre-war years perhaps indicates a search for comforting continuity with the past in uncertain times.

An antagonistic article in Politik und Wirtschaft (1954) suggested that a large number of the listeners came from the circles of the right-wing DRP,

I85 Grimm to Heuser, II.I2.1953 and I2.II.1957, DLA - A: Grimm, Grimm to Heuser 1935-1959.

I86 A large collection of photographs of the event can be found with Grimm's papers, DLA - A: Grimm, Bildkonvolut Hans Grimm. See also Tourlamain, 'In Defence of the Volk'.

I87 H. Heick, 'Nun spinnen sie wieder ...' in Impuls - Göttinger Schülerzeitschrift, Jahrgang I, Heft 7, Oktober / November 1949, p. I00, DLA - A: Grimm / Lippoldsberger Dichtertage: Konv - Zeitungsberichte Dichtertag 1949 u. 1950; Kasseler Zeitung, 17.8.1949, DLA - A: Grimm / Lippoldsberger Dichtertage: Konv - Zeitungsberichte Dichtertag 1949 u. 1950. 
for which Grimm had stood as a candidate in the Bundestag election the previous year. Alongside the later leader of the DRP, Adolf von Thadden, the newspaper identified further representatives of right-wing groups and publications, including Arthur Ehrhardt from the journal Nation Europa, Bruno Fricke of the Deutsche National-Zeitung and Dieter Vollmer of Der $W e g .{ }^{188}$ The accusation that Grimm's meetings played host to former Nazis and neo-Nazis also appeared in other publications in the course of the 1950s. In 1955, Wolfgang Wirsig contributed a piece to the Hannoversche Presse, in which he described the visit to Lippoldsberg of the members of the Hanover branch of the 'Deutsches Kulturwerk europäischen Geistes', a right-wing organisation established in Munich by the writer Herbert Böhme. Similarly, in 1957 the Neue Presse contrasted the earlier meetings with those of the later 1950s, suggesting that the latter were now attended by 'einige Herren mit Breeches und Wickelgamaschen. Frauen mit der deutschen Sendung im Blick. Knotenfrisur überwiegt. Man ist unter sich. ${ }^{189}$ In addition, the presence of a youth group dressed in a uniform of black shirts, with knives in leather cases and emblems on their breasts was noted.

Nonetheless, the crowds appear to have been mixed, as Holle Grimm (Grimm's daughter) suggested in a letter to Hans Venatier in 1954: 'Perhaps you are asking who you will have before you as listeners. I would respond by saying, a cross-section of society, of the entire Volk, politically people who feel themselves to be absolutely German.' ${ }^{190}$ Overall, it would seem that the reasons for attendance varied, with an increasingly right-wing political agenda becoming evident over the course of the decade. Nonetheless, there were still some listeners with less overt political intentions. While, as Holle Grimm's comments suggest, Hans Grimm and his associates viewed the presence of substantial crowds as an endorsement of their own 'German' position, it is likely that many visitors simply enjoyed the day out on the banks of the Weser, as they had during the 1930s. The appeal of the events,

I88 Politik und Wirtschaft, 23.7.1954.

I89 'Legendäres aus Lippoldsberg', Neuen Presse, 16.7.1957, DLA - A: Grimm, Dichtertage, Zeitungsberichte, 1957.1958.

I90 Holle Grimm to Hans Venatier, 22.4.1954, DLA - A: Grimm, Grimm to Venatier, 1932-1958. 
beyond immediate entertainment, could be found in their familiarity, which provided reassurance that not everything in Germany had been bad before 1945. Continuity was not only evident, but also part of the appeal of the Lippoldsberger Dichtertage after the War. The desire for familiar literature also allowed völkisch-nationalist writers to revive their careers after 1945. Their position with regard to the changed circumstances in West Germany in the post-war era is examined in the following chapter. 



\section{Völkisch-Nationalism in the Post-War Era}

In 1962, Walter Laqueur noted the tendency of German intellectuals in the 1950 s to consign the nationalist writers of the Third Reich to oblivion in their determination to reject the Nazi regime itself. He contested this dismissive assumption and commented: 'Some of them are apparently more widely printed and, presumably, read than even the better-known contemporary writers of the "democratic-liberal" camps. True enough, their books are not widely discussed, and they certainly are of no interest to the literary avant-garde, but they have their faithful public, a fact that is usually ignored by the literary critics.' ${ }^{1}$ Following the Second World War, writers who had been prominent in the Third Reich, particularly those who had occupied leading positions in political and cultural institutions, were subject to the Allies' denazification and re-education programmes. A demand for their works nonetheless continued to exist and by 1950 their books were widely available again as publishers sought to satisfy the desire of the German public for familiar literature. ${ }^{2}$ Hans Sarkowicz estimates that only one-sixth of the recipients of literary prizes, honours and awards under the supervision of Goebbels and the Reich Chamber of Literature between 1933 and 1945 published nothing at all after the War. ${ }^{3}$ Similarly, Gregor Streim has demonstrated the popularity in the 1950s of accounts of post-war imprisonment in Allied internment camps. He places these in

I Quoted by Stefan Busch, 'Und gestern, da hörte uns Deutschland': NS Autoren in der Bundesrepublik. Kontinuität und Diskontinuität bei Friedrich Griese, Werner Beumelburg, Eberhard Wolfgang Möller und Kurt Ziesel (Würzburg: Königshausen \& Neumann, 1998), p. 9.

2 Ibid., p. I7. See also Sarkowicz, 'Die literarischen Apologeten des Dritten Reiches', pp. $436-437$.

3 Hans Sarkowicz, 'Die literarischen Apologeten', p. 436. 
the context of post-war perceptions of German victimhood, which, while not exclusive to the far right, also came to play a significant role in völkisch analyses of Germany's recent past. ${ }^{4}$

The careers of writers like Hans Grimm and his fellow Münchner demonstrate a line of continuity from the Kaiserreich, through the Weimar Republic and Nazi Germany, into the early years of the Federal Republic. This chapter will examine their position after the Second World War. After I 945 the surviving members of the Munich Consensus presented their campaign for autonomy and control over their own institutions in the Third Reich as evidence that they had not been implicated in the crimes of the Nazi regime. Their ambiguous attitude towards the Third Reich is central to understanding their position after the Second World War. In the West German political context of the I950s they also claimed to have been forced into a new inner emigration.' They denied a share in responsibility for the Nazi crimes and rejected ideas of collective guilt, emphasising instead that their role in the political developments of the preceding decades was based in an older nationalist tradition that had roots in the search for a German national identity in the nineteenth century. They were not products of National Socialism, which in their eyes had betrayed its initial promise by its distortion of healthy German aspirations. ${ }^{6}$ For them, the Nazi regime had never been an end in itself. They thus remained blind after 1945 to the full implications of the crimes of the Nazi era and saw little reason why the failure of National Socialism should cause them to abandon their crusade for a völkisch political and social order. Indeed, picking up on widespread

Gregor Streim, 'Germans in the Lager. Reports and Narratives about Imprisonment in Post-War Allied Internment Camps', in Helmut Schmitz (ed.), A Nation of Victims? Representations of German Wartime Suffering from 1945 to the Present (Amsterdam: Rodopi, 2008), pp. 3I-49.

Grimm, Die Erzbischofschrift, p. 126. See also reports on the comments of Grimm and, in particular, Vesper to reporters at the Lippoldsberger Dichtertage in 1950: E.g. 'Der Leser spricht - Begegnung mit Grimm und Kolbenheyer', Westfälische Zeitung, 19.7.1950; 'Armes Lippoldsberg', Süddeutsche Zeitung, 25.07.1950; handwritten copy of an article with the title 'Wie wir hören', Aufbau, 8.09.1950, DLA - A: Grimm, Dichtertage - Zeitungsberichte, 1949-1950. 
resentment at the treatment of Germans in the immediate post-war period, and their suffering in the midst of the material and psychological destruction the Second World War left behind, they continued to demand equality for Germany on the world stage and understanding for the long-term causes that had led to the Third Reich (as they understood them).

At the same time, after 1945 völkisch writers were forced to fight for their territory in a contested cultural sphere. In doing so, many dogmatically clung to old certainties in the face of social and political change at home and the ideological polarisation of the global order. While political adversity fuelled their determination in old age to avert what they viewed as dangerous and unhealthy trends in post-war Germany, they cannot be written off simply as relics of a previous era. Experience had taught men and women of this generation that political systems could disappear as quickly as they came. There was no reason to suppose in 1950 that the new West German order would be permanent, particularly given the absence of a formal peace treaty, the temporary nature of the Basic Law and taking into account the division of Germany and perceived threat of socialism coming from the East.

In addition, their belief in a national community along the lines of the now discredited Volksgemeinschaft meant that they felt obliged to place their experience of the past at the service of the German people. While they failed to restore völkisch ideas as the guiding principles for social and political organisation, they actively sought to shape the new Germany and found a considerable audience for their efforts. Investigating the role of völkisch literature in the context of the post-war transformation of Germany, this chapter highlights some of the tensions and contradictions of the period. While the publishing success of völkisch works between 1945 and 1960 points to the existence of a substantial readership for their works, they found themselves increasingly excluded from formal political discourse. But this process of exclusion in the cultural and literary spheres occurred over time and reflected Germany's gradual transformation into a liberal-democratic state with a social-market system. ${ }^{7}$

7 Everhard Holtmann, 'Flüchtlinge in den soer Jahren: Aspekte ihrer gesellschaftlichen und politischen Integration', in Schildt and Sywottek (eds), Modernisierung im 


\section{Questioning Collective Guilt}

Since Germany's reunification in 1990 , commentators on the memory of the Third Reich have displayed renewed interest in the character of the FRG in the I950s. The results have produced an increasingly nuanced understanding of West German responses to the Nazi past in that decade. The apparent failure or refusal of Germans to acknowledge German culpability for the Nazis' crimes now appear as responses to a complex set of circumstances informed by both domestic and international politics after the War, alongside social and cultural issues arising from the destruction of war, defeat and the movement of peoples, against the background of exposure to the full extent of the evils of Hitler's regime. The result has been the emergence of a critical understanding of the way in which public and private memories have developed since 1945 . This also takes into account the demand of the generation that came of age in the 1960 s that their parents and grandparents acknowledge German responsibility for the Nazi past, which has led to the normalisation of a discourse of guilt in the final decades of the twentieth century that was less widely accepted in the decade after the War. ${ }^{8}$ Commenting on the Walser-Bubis debate, unleashed by Martin

Wiederaufbau, pp. 349-36r. See also Anthony J. Nicholls, The Bonn Republic: West German Democracy, 1945-199o (Basingstoke: Macmillan, 1997), p. II; Christoph Hendrik Müller, West Germans against the West: Anti-Americanism in Media and Public Opinion in the Federal Republic of Germany, 1949-1968 (Basingstoke: Macmillan, 2010), p. 26.

8 The discussions on this subject have not been limited to the academic sphere, but have also been evident in public discourse. Following the Historikerstreit of the I980s, a new wave of debate occurred in the wake of Martin Walser's controversial acceptance speech in Frankfurt on being awarded the Friedenspreis der deutschen Buchhandel in 1998 . The question of public vs. private memory raised by Walser, as well as debates concerning Germany's 'normalisation' as a nation have been accompanied by a number of significant academic studies on the subject: See, for example, Norbert Frei, Vergangenheitspolitik: Die Anfänge der Bundesrepublik und die NS-Vergangenheit (Munich: Beck, 1997); Norbert Frei, 1945 und Wir: Das Dritte Reich im Bewußtsein der Deutschen (Munich: Beck, 2005); Aleida Assmann and Ute 
Walser's speech on receiving the Friedenspreis des Deutschen Buchbandels in 1998, Aleida Assmann notes the way, over time, mainstream German historical consciousness has come to endorse the perspective of the Nazis' victims. 'This consensus has loosened a little since Assmann was writing in 1999; Walser's debate with the Holocaust survivor Bubis was a symptom of, rather than a catalyst for, the re-emergence of multiple, often contradictory memories of the Nazi era over the last decade. Walser highlighted a divergence between official, public memory and the private memory of individuals. As his generation, the last eye-witnesses, moved towards old age, he appealed for the validity of private memory, informed by the conscience of individuals, in the face of what he viewed as the 'politically

Frevert, Geschichtsvergessenheit; Geschichtsversessenheit: Vom Umgang mit deutschen Vergangenheiten nach 1945 (Stuttgart: Deutsches Verlags-Anstalt, 1999); Aleida Assmann, Geschichte im Gedächtnis: Von der individuellen Erfahrung zur öffentlichen Inszenierung (Munich: Beck, 2007). In addition, discussions of German victimhood during and directly after the Second World War have increasingly become part of mainstream political culture in Germany in the last two decades. Jörg Friedrich's Der Brand: Deutschland im Bombenkrieg, I940-1945 (Munich: Propylöen, 2002) drew attention to the carpet bombing of German cities. Further works, including Randall Hansen's Fire and Fury: the Allied Bombing of Germany 1942-1945 (Toronto: Doubleday, 2008) have adopted a critical position on Allied strategy. While the memory of German expulsions from Central and Eastern Europe in 1945/46 has been kept alive by various organisations representing the interests of various expellee groups, the dissolution of the Bundesministerium für Vertriebene, Flüchtlinge und Kriegsgeschädigte in 1969 removed the issue to a large extent from daily political discourse. While the extra-parliamentary Bund der Vertriebenen sought to keep the issue alive, refusing to recognise Germany's eastern boundaries, it has only been in recent years that the debate over the establishment of a Centre for Expulsions in Berlin has brought it to the surface of wider German political and cultural consciousness once more. A number of works have emerged in recent years that engage directly with the discussion of German victimhood and its memory. These include but are not restricted to: Bill Niven (ed.), Germans as Victims: Remembering the Past in Contemporary Germany (Basingstoke: Macmillan, 2006); Helmut Schmitz (ed.), A Nation of Victims? Representations of Wartime Suffering from 1945 to the Present (Amsterdam: Rodopi, 2008). Assmann and Frevert, Geschichtsvergessenheit; Geschichtsversessenheit, pp. 22-23. 
correct' manner of remembering the Holocaust that had developed in Germany over the previous half century. ${ }^{10}$

Widespread acceptance of a public discourse of German guilt was gradual, the product of an 'ongoing process of critical dialogue (Auseinandersetzung) between the present and the past. ${ }^{\text {'11 }}$ As Assmann points out, this Auseinandersetzung with the Nazi past began immediately following the Second World War. Nonetheless, in the immediate postwar decades, moral requirements to engage with the crimes committed in Germany's name competed with the long-term legacy of resentment left by the war guilt clause of the Versailles Treaty and the need to deal with defeat in a second European war in the space of thirty years, to say nothing of the basic requirements of survival in the initial post-war years. In addition, twelve years of Nazi ideological education, communicated through the regime's propaganda initiatives, inevitably shaped attitudes to the idea of 'collective guilt'. As a result, as the völkisch contributions to the discussion of German guilt also help demonstrate, responses to the recent past were mixed, in spite of the efforts of the victorious powers to re-educate the German population.

I 945 cannot be viewed as zero hour in German culture, even if the idea of Stunde Null held currency for some contemporaries. ${ }^{12}$ Nonetheless, 1945 was a historical watershed and for the German people the future looked unclear as the Allied powers divided the country into four zones of military occupation. Thus began what Norbert Frei has labelled the first phase of dealing with the Nazi past, characterised by the only moderately successful

Io 'Erfahrungen beim Verfassen einer Sonntagsrede', acceptance speech by Martin Walser on receiving the Friedenspreis des Deutschen Buchhandels in the Paulskirche, Frankfurt a/M, II.IO.1998. See also: Gregor Streim, 'Germans in the Lager. Reports and Narratives about Imprisonment in Post-War Allied Internment Camps' in Schmitz (ed.), A Nation of Victims?, pp. 31-32.

II Aleida Assmann, 'Gedächtnisgeschichte' in Assmann and Frevert, Geschichtsvergessenheit; Geschichtsversessenheit., pp. 30-3I.

I2 See, for example, Stephen Brockmann, German Literary Culture at the Zero Hour (Rochester, NY: Camden House, 2004). 
denazification and re-education policies directed by the Allied occupiers. ${ }^{13}$ Nonetheless Frei points out

that it is inadequate to view this phase of Säuberungspolitik solely in the simplified terms of failed denazification, as was long common in the historiography. For, between I945 and 1949 'Persilscheine' were not the only things issued; war criminals were also severely punished, NS-functionaries were interned, in some cases for many years, and so-called Mitläufer were held accountable in ways that had considerable impact. ${ }^{14}$

It was against this background that the surviving members of the Munich Consensus, Grimm, Kolbenheyer, and to a lesser extent Strauß and Schäfer, operated after 1945. Far from encouraging silence with regard to the Nazi past, their strategies to shift the blame for the crimes committed under Nazi rule and loud expressions of resentment at perceived Allied accusations of collective guilt, to say nothing of their anger over the 'denazification' and 're-education' measures, were also discourses on the Nazi past. Both political and popular culture in Germany underwent a substantial shift in the course of the 1950s. This shift is also reflected in the position of Hans Grimm and his colleagues in relation to German political and cultural discourses.

Underpinning their defence of völkisch thought was a determined rejection of the so-called Kollektivschuldthese. Frei has identified this as the second phase of addressing the Nazi past, characterised by the Vergangenheitspolitik of the first decade of the FRG. ${ }^{15}$ This being the case, Grimm and his colleagues were not out of tune with a large proportion of their compatriots. Successive amnesty laws allowed the re-integration of former officials of the Nazi regime and encouraged the suppression of memories of the Nazi past, ostensibly in the service of social cohesion. Adenauer's government thus adopted a largely pragmatic stance in order to establish the West German state. At the same time, the new order formally accepted its Nazi inheritance, for example in the Basic Law and

13 Frei, 1945 und Wir, p. 28.

I4 Ibid.

I5 Ibid., pp. 30-34;also Norbert Frei, Vergangenheitspolitik. 
West German compensation to the Jews in the form of support for the new state of Israel. The combined outcome of these two positions was the inculcation of a widespread 'Schlußstrich' mentality in the public at large, as it became both expedient and acceptable to bury the past in favour of a concentration on Germany's future. ${ }^{16}$

Frei suggests that the Kollektivschuldthese was a German construction that proved useful to legitimise the Vergangenheitspolitik of the i950s. He points out that historians have not uncovered any documentary evidence of an officially articulated principle on behalf of the Allied occupiers. ${ }^{17}$ Similarly, Helmut Dubiel has shown that the idea of 'collective guilt' is repeatedly referred to in Bundestag debates of the I950s. His conclusions support Frei's suggestion that it was manifested most strongly in German efforts to refute the idea. ${ }^{18}$ All the same, there can be little doubt about the message communicated by the victorious Allies to the German people, even before the end of the Second World War. Indeed, the arguments presented by Frei and Dubiel draw on examples of defensive reactions that serve to highlight the extent to which the idea became ingrained in German consciousness in response to Allied efforts to confront the German people with the crimes of the Nazi regime.

The Morgenthau Plan, first proposed in 1944, called for the dismantling of the German state and German industry following her defeat. While it was reflected in the official United States policy in occupied Germany between 1945 and 1947 , it was not implemented on the ground. ${ }^{19}$ All the

Frei, 1945 und Wir, pp. 31-32. Fritz Stern, Dreams and Delusions: National Socialism in the Drama of the German Past (New York: Yale University Press, 1989), p. 16.

I7 Frei, I945 und Wir, p. I45.

I8 Helmut Dubiel, Niemand ist frei von der Geschichte: Die nationalsozialistische Herrschaft in den Debatten des Deutschen Bundestages (Munich: Hanser, 1999), p. 71; also quoted by Assmann in Assmann and Frevert, Geschichtsvergessenheit; Geschichtsversessenheit, pp. II6-II7. See also Wolfgang Benz, 'Etappen bundesdeutscher Geschichte am Leitfaden unerledigter deutscher Vergangenheit' in Brigitte Rauschenbach (ed.), Erinnern, Wiederholen, Durcharbeiten (Berlin: Aufbau, I992), p. I20.

I9 Directive to Commander-in-Chief of United States Forces of Occupation Regarding the Military Government of Germany of April 1945 (Joint Chiefs of Staff Directive I067), especially $\$$ I6. See also: Michaela Hoenicke Moore, Know your Enemy: The 
same it did much to damage the faith of many Germans in the intentions of the American occupiers in particular. In the minds of far-right commentators it was linked with the Allies' early occupation policies, when economic activity in Germany, with the exception of agricultural production, was more or less suppressed..$^{20}$ These years were also years of hunger for the German population, criticised not only on the right, but also by left-wing commentators. The latter included the British publisher and publicist Victor Gollancz, whose treatise criticising conditions in the British occupation zone in 1946, Our Threatened Values, also received an enthusiastic reception in Germany, not least from Hans Grimm and his völkisch colleagues. ${ }^{21}$ Criticisms of Allied policy by men like Gollancz only served to endorse the resentment of the far right. The Morgenthau Plan, suggests Christoph Müller, became 'a myth with often anti-Semitic overtones' with roots in Nazi propaganda, which continued to raise passions throughout the $1950{ }^{22}{ }^{22}$ It provided an early focus for völkisch convictions that the occupation powers were intent on the destruction of the German nation, as, it was believed, they had been since its emergence as world power after $187 \mathrm{I}^{23}$

Assmann has also pointed out that the forced visits of German citizens to concentration camps in 1945, as well as the posters, photographs and film footage of the camps and their victims to which the population was exposed after the War served to fix in German minds not a sense of responsibility, but resentment at Allied propaganda. The result, she suggests, was a psychological gap between perceptions of the Nazis' crimes and the

American Debate on Nazism, I933-I945 (Cambridge: Cambridge University Press, 20Iо), chapters Io and II.

20 Kolbenheyer, Sebastian Karst, vol. I, p. 40I; Grimm, Warum - Woher - Aber Wohin?, pp. 381, 489-491.

2I Victor Gollancz, Our Threatened Values (London: Gollancz, I946). See for example Grimm to Gollancz, 4.4.1947, DLA - A: Grimm, Grimm to Victor Gollancz, 1947. Also: Grimm to Miegel, 31.I.47, 25.2.1947 and 29.4.1947, DLA - A: Grimm, Grimm to Agnes Miegel, 1933-1959.

22 Müller, West Germans against the West, p. I5; pp. 44-54.

23 Grimm, Die Erzbischofschrift, pp. 15-96. 
personal memories of individuals. ${ }^{24}$ This argument is supported by an examination of völkisch writers like Hans Grimm. The need to repudiate the Kollektivschuldthese became paramount if they were going to separate their own ideological position, and belief in the German Volk, from the legacy of National Socialism. In their response to the idea of 'collective guilt' they not only denied knowledge of, let alone involvement in the actions of the Nazis, but also presented a relativised view of National Socialism that generally allowed that the fate of the Jews was horrible but exaggerated, and weighed it against the suffering of Germans.

A prominent example was Grimm's first substantial post-war work: the Erzbischofschrift, delivered a basis for völkisch thought in the decade that followed. It was published in 1950 as an extended version of his response to a radio address by the Archbishop of Canterbury, Geoffrey Fisher, to the German people, broadcast in November 1945. The Archbishop's address was subsequently reprinted in a German translation in several licensed newspapers in the British occupation zone. ${ }^{25}$ In 1947 Grimm managed to send his 80 -page response to Lambeth Palace in spite of restrictions on parcels Germans could send abroad. ${ }^{26}$

In considering the Erzbischofschrift as an early example of the post-I945 völkisch programme, it is important to note that the book was aimed at rebutting the accusation of collective guilt. In examining the text, it is also necessary to consider not only its content, but also the strategies Grimm adopted in presenting his argument. His use of quotations is striking. In order to provide legitimacy for his positions, he frequently quoted at length, and often out of context, in place of providing his own concluding statements. In doing so, he sought to demonstrate that his conclusions were shared by other, respectable thinkers. The tone of the text is also typical of völkisch publications in this period; it communicates a sense of patient reasonableness in the face of obvious stupidity in the responses of

\footnotetext{
24 Assmann and Frevert, Geschichtsvergessenheit; Geschichtsversessenheit, p. I25.

25 Grimm, Die Erzbischofschrift, p. 9.

26 Grimm to Archbishop Fischer, 7.5.1946, DLA - A: Grimm, Grimm to Canterbury, Erzbischof, 1946-1950.
} 
the occupying powers and, later, German authorities to the grievances of the German people.

Grimm's arguments may appear stubbornly blind to the realities of Germany's history and her situation in the late 1940s and early 1950s, but there is little doubt that he genuinely subscribed to the views he put forward. It is evident in his correspondence with a wide range of men and women from various places and many different walks of life that, while he may have combined arrogance with an inability to understand the full implications of the legacy of the Nazi regime, he was not deliberately duplicitous. Indeed, it was a matter of honour to Grimm to represent his truth, even if it was unpopular. And he was encouraged by his communications with friends and colleagues, both in Germany and abroad. He received praise and support from a number of quarters for articulating what many Germans felt. ${ }^{27}$ The Erzbischofschrift also sold well, providing Grimm with much-needed income after the loss of much of his wealth as a result of the currency reform in $1948 .^{28}$

Grimm's work after 1945 introduced little that was new to his völkisch worldview. Instead, he applied this ideological position to the new historical circumstances in which he found himself forced to live. The survival of volkisch thinking lay in large part in the malleability of the ideology, which allowed its adherents to apply it anew as Germany's circumstances changed and developed. This was also true after the Second World War. The material destruction of Germany as a result of the War combined with the ongoing antagonism against the Germans perceived to be inherent in the Allied occupation policies were not seen to challenge but to endorse the völkisch worldview.

In the Erzbischofschrift, Grimm suggested that National Socialism had begun as an idealistic, healthy response to Germany's problems in the

27 For example Kolbenheyer to Grimm, 4.5.1950 and Ir.9.1950, DLA - A: Grimm, Kolbenheyer to Grimm, 1946-1959; A. von Ribbentrop to Grimm, I4.II.1950, 21.7.1951, DLA - A: Grimm, Annelies von Ribbentrop to Grimm, 1950-1951; Miegel to Grimm, I.3.1947, DLA - A: Grimm, Miegel to Grimm, 1933-1959.

28 Grimm to A. von Ribbentrop, 13.12.1950, DLA - A: Grimm, Grimm to Annelies von Ribbentrop, 1950-1954. 
early 1930s. Only later, he argued, did Hitler's increasingly unstable mental health corrupt the original idealism of the movement. ${ }^{29}$ By contrast, in 1954 he published Warum - Woher - Aber Wohin?, in which he emphasised a positive view of the Nazi leader throughout and the negative role played by Nazi functionaries who put personal ambitions and factional rivalries before the good of the German people. ${ }^{30}$ Either way, the idea that Nazi ideology had been subject to distortion and corruption in the later years of the regime remained fundamental to his defence. An important part of Grimm's response to the idea of collective guilt was to separate enthusiasm for the völkisch characteristics of early National Socialism from the later actions of the regime's leading figures: the crimes committed during the War, which included those against the European Jews, no longer represented the 'pure', 'healthy' National Socialism that had originally been endorsed by the German population. ${ }^{31}$

Grimm also insisted that responsibility for the long-term causes of the 'German catastrophe' lay with the Allies. Moreover, failure to acknowledge the role played by the desire for revenge on the part of the enemies of the Nazi regime, both at home and abroad and including but not restricted to the Jewish survivors of the regime, led to the establishment of the new and dangerous post-war order. With the division of Germany, Europe was opened up to the advance of Bolshevism in the East. Grimm argued in Warum - Woher - Aber Wohin? that Hitler had been among the first to recognise this threat to European civilisation and suggested that Second World War had been a struggle to allay it. The Western Allies should have joined Germany in the anti-Bolshevist cause, rather than opposing Hitler.

29 Grimm, Die Erzbischofschrift, pp. 29-34, 89, 92, 95-96.

30 Grimm, Warum - Woher - Aber Wohin?, pp. 204-221. Grimm also expressed this view particularly strongly in his correspondence with Annelies von Ribbentrop in these years. See, for example, Grimm an A.v.Ribbentrop, I3.II.1950; 20.03.1951; II.IO.1952; 26.12.1953; 6.08.1954, DLA - A: Grimm, Grimm an Annelies von Ribbentrop, 1950-1954. Also Grimm an A.v.Ribbentrop 20.12.1957, DLA - A: Grimm, Grimm to Annelies von Ribbentrop, 1955-1959.

3I Grimm also presented this view to Victor Gollancz in his letter of April 1947, DLA - A: Grimm, Grimm to Gollancz, 4.4.1947. 
Their mistaken antagonism towards the Nazi regime had resulted in the establishment of two German states in 1949. By preventing the development of the German nation to its full potential and allowing the Soviets to make deep incursions into Central Europe, the western powers were responsible for aiding rather than hindering Europe's downfall. ${ }^{32}$

\section{Re-establishing Völkisch Networks}

The position of völkisch-nationalist writers after the Second World War reflected the experiences of large sections of the wider German population. In particular, as far as the Allies' 'denazification' and re-education programmes were concerned, Germans' experiences were determined not only by the occupation zone in which they found themselves living, but also the arbitrary nature of the 'denazification' procedures themselves. Some, including Kolbenheyer, Johst and Blunck, were severely affected by the process, both materially and psychologically. Others were left almost completely untouched. Both Grimm and Agnes Miegel emerged unscathed from the process in the American and British zones respectively.

The limited success of 'denazification' and re-education was evident in the subsequent careers of these writers. Far from changing their ideas or political views, 'denazification' served to confirm for them and their supporters that the Germans were subject to determined strategies to undermine the Volk through malignant propaganda and reprisals. A negative outcome, while proving costly financially, did not necessarily mean the end of a literary career. Blunck, pronounced a 'Mitläufer' by the 'denazification' commission in Kiel in 1949, continued to publish his Heimat tales in the

32 Grimm, Warum - Woher-Aber Wohin?, pp. 338-353. This is also a running theme in Grimm's Erzbischofschrift. See also Hans Grimm, 'Mein Europäisches Bekenntnis' in Erkenntnisse und Bekenntnisse, pp. 9-37. 
I950s. ${ }^{33}$ Kolbenheyer was the recipient of the Sudetendeutscher Kulturpreis in 1958 , the same year in which the final volume of his autobiographical novel Sebastian Karst appeared.

Grimm had a smooth ride through 'denazification'. Resuming contact with Kolbenheyer in 1946, he commented that 'I did not suffer unduly under the occupation, even though the mistaken view circulated that "Volk ohne Raum" was a National Socialist work written for propaganda purposes!' ${ }^{34}$ His repeated testimonies in the years that followed, written in his own interest and in support of others, state that he emerged in category five as 'unbelastet', emphasising that he had not been a member of the NSDAP and that his relationship with the regime had become increasingly ambivalent in the course of the 1930 s. $^{35}$ All the same, the apparent lack of concern regarding Grimm remains surprising given his involvement in the Literature Academy and particularly his position on the Präsidialrat of the RSK between 1933 and 1935. According to the Gesetz zur Befreiung von Nationalsozialismus und Militarismus (Liberation Law) passed in the American zone on 5th March 1946, Hauptschuldige unless proven otherwise included: 'Reichskulturkammer - all presidents, vice-presidents and executive directors. All members of the Reichkulturrat, the Reichkultursenat and presidential councils (Präsidialräte). ${ }^{36}$

No copy of a completed 'denazification' questionnaire or formal notification of Grimm's clearance has so far come to light in his papers. ${ }^{37}$ Nonetheless, every German in the American zone over the age of 18 was required to complete a questionnaire, leading to a total of $13,199,778$

33 Sarkowicz and Mentzer, Literatur in Nazi-Deutschland, pp. I03-IO4.

34 Grimm to Kolbenheyer, I2.9.1946, DLA - A: Grimm, Grimm to Kolbenheyer, 1933-1959.

35 Manfred Franke offers further discussion of the nature of these testimonies in, Grimm ohne Glocken: Ambivalenzen in politischen Denken und Handeln des Schriftstellers Hans Grimm (Cologne: S.H. Verlag, 2009), pp. I5I-I68.

36 Quoted by Düsterberg, Hanns Johst, p. 33 I.

37 I am grateful to the staff of the Deutsches Literaturarchiv, Marbach, in particular Frau Dieke, for conducting repeated searches in Grimm's papers in order to ascertain whether he kept any records of the 'denazification' process. None have come to light. 
responses to the I3I questions. Of these 3,445,062 appeared before tribunals (Spruchkammer). ${ }^{38}$ While the absence of formal documentation in his otherwise full archive is notable, Grimm does mention having filled in the questionnaire in a letter to Miegel and there is enough evidence to conclude that for him the process ended in complete clearance. ${ }^{39}$ In 1946 , he provided a testimony for Ernst von Salomon, who was incarcerated by the Americans immediately after the war on suspicion, according to Grimm, of militarism on account of his earlier writing. ${ }^{40}$ Von Salomon was released in November of that year. In the years that followed, Grimm wrote further affidavits on behalf of several colleagues, including Miegel and Edwin Erich Dwinger, both of whom had been members of the NSDAP. ${ }^{41}$

While, officially, Grimm was not viewed as having been implicated in the Nazi regime, in the course of the decade that followed, his activities were increasingly associated with the far right, including surviving elements of the Nazi camp. In addition to the attention drawn by the Lippoldsberger Dichtertage, this was not least the result of his post-war writing, as well as lectures to right-wing groups and organisations. Grimm identified in public with the experiences of those of his colleagues whose passage through 'denazification' was less comfortable than his own. He also took up the cause of the former Nazis imprisoned in Landsberg and Spandau. ${ }^{42}$ In doing so, he became an apologist for those who had been representatives of the Nazi

38 Düsterberg, Hanns Johst, pp. 33I-332; see also Peter Reichel, Vergangenheitsbewältigung in Deutschland: Die Auseinandersetzung mit NS-Diktatur in Politik und Justiz (Munich: Beck, 2007), pp. 30-4I.

39 Franke also reports that Grimm was categorised as 'unbelastet' (category 5). Nonetheless, Franke also relies on Grimm's own reports and the fact that he provided so-called 'Persilscheine' for others as evidence. He provides no reference to any formal documentation of Grimm's 'denazification'. See Franke, Grimm ohne Glocken, p. I5I. See also Grimm to Miegel, 25.02.1947, DLA - A: Grimm, Grimm to Miegel, 1933-1959.

40 Grimm to Heuser, I5.II.1946, DLA - A: Grimm / Amerika: Grimm to Heuser, 1935-1959.

4I See DLA - A: Grimm, Entlastungsschreiben.

42 Grimm to Ilse Hess, 30.12.1947, 26.11.1946, 20.12.1949, DLA - A: Grimm, Grimm to Ilse Hess, 1936-1952; Grimm to Rudolf Hess, 19.12.1947, DLA - A: Grimm, Grimm 
regime. The establishment of his own publishing house, the KlosterhausVerlag, in I95I assured not only continued publication for his own works, but also allowed him to assist other likeminded writers to present their views in print.

'Denazification', in Grimm's view, was based on the misconception that supporters of the Nazis' original attempt to reform the life of the German Volk in the early years of the movement had been at fault from the start. Grimm thus distanced himself and those völkisch colleagues who shared his initial enthusiasm for the movement in the early 1930 f from the accusation that they helped prepare the way for what went wrong later on. He added, repeatedly, that the alternative had been Marxism. For Grimm, greater distinction was needed between former Nazis, honourable Germans and those who sought to exploit the post-war situation for their own ends. While he acknowledged that there had been victims of the regime, he nonetheless suggested that the prisoners of the camps had been mixed; some, at least had been justly incarcerated. He warned against the influence of these people after 1945, alongside those who had been exiled from the Third Reich, at the expense of 'the clean Germans, who stand by their country, and their language and culture, and who have been forced into silence. ${ }^{33}$

Grimm also argued that 'denazification' had wrongly focused on the destructive anti-Semitism that had developed later on in the Nazi regime. In short, he concluded, the fact that true National Socialism had had a positive impact on community life in many places had been forgotten or deliberately ignored. ${ }^{44} \mathrm{His}$ analysis displayed his own anti-Semitism, as he argued against the dangerous identification of Jews as victims, noting the power survivors and their 'co-religionists' had in post-War Germany. Grimm sought to create a distinction between the murderous anti-Semitism of a few in the final years of the Nazi regime and a more reasonable, indeed appropriate, anti-Semitism rooted, he believed, in the desire to defend the

to Rudolf Hess, 19.12.1947. See also Grimm to A.v. Ribbentrop, 9.3.1951, 9.6.1951, 5.9.1952, DLA - A: Grimm, Grimm to Annelies von Ribbentrop, 1950-1954.

43 Grimm to Heuser, I2.061947, DLA - A: Grimm, Grimm to Heuser, 1935-1959.

44 Grimm, Die Erzbischofschrift, pp. 122-123. 
German Volk from the negative intentions of Eastern European Jews. He acknowledged that the killings in the concentration camps had been wrong, but insisted that the numbers had been exaggerated. He also argued that the crimes of the Nazis were an extreme expression of a reasonable, more moderate caution that the German people had displayed towards Jews who threatened Germany's wellbeing. ${ }^{45}$

Grimm believed this distorted view of the German situation was plainly manifested in German cultural, particularly literary life, not least in an ongoing propaganda struggle on the part of Bolsheviks, alongside those with a sometimes legitimate but more often illegitimate desire for revenge, to suppress real German literature. The latter was represented by the likes of Strauß, Schäfer, Kolbenheyer, Claudius, Carossa, Vesper, and himself, as well as Weinheber, Miegel and Ina Seidel. ${ }^{46}$ Their forced silence, he warned, was not helping America's cause; against this background, he suggested to Prof. Heuser in New York, the German view of the USA was growing increasingly negative as a result of measures imposed by the occupation authorities. He suggested that reasonable Germans had previously hoped that the Americans would have some sympathy for the Germans' situation; now, however, the Americans had shown themselves to be influenced by the Jews. And while he suggested that most Germans would concede that the Jews had a legitimate grievance, he argued that the desire for revenge was an unsuitable basis on which to make judgements or build a new order. ${ }^{47}$

Grimm took up the challenge that he felt the denazification process posed to the German Volk by engaging directly with the interests of colleagues whose situations were less fortunate than his own. In doing so, he further established himself in his self-appointed role as a völkisch activist and commentator in the post-war era, as well as a coordinator of völkisch networks and activities. 'Denazification' was one factor of several that contributed to creating uncertainty, both materially and intellectually, in

45 Grimm, Warum - Woher-Aber Wohin?, pp. 185-189.

46 Grimm to Heuser, 4.0I.1947, DLA - A: Grimm / Amerika: Grimm to Heuser, 1935-1959.

47 Grimm to Heuser, 12.06.1947, DLA - A: Grimm / Amerika: Grimm to Heuser, 1935-1959. 
the lives of völkisch-nationalists. Grimm's correspondence in the immediate post-war years reflects this. Gradually re-establishing contact with old friends and colleagues, and in some cases establishing it for the first time, the letters are full of enquiries and shared information not only concerning the situation of the correspondents themselves, but also mutual acquaintances, and above all shared concerns about the future of the 'German' cause. They provide an insight into the efforts of these writers to engage with and make sense of the new situation they faced after 1945, many of them like Grimm confronting uncertain times in old age.

A number of significant figures abroad became regular, friendly and supportive correspondents. In some cases, moreover, the initiative for the resumption of communication came not from Grimm, but from old friends like Prof. Heuser in New York, who had attended the Lippoldsberger Dichtertage in 1937 and wrote to Grimm on 17 th April 1946 enquiring after his wellbeing and that of his family. ${ }^{48}$ Among British friends, Edmund Blunden and the lawyer, Dennis Thompson, were among those with whom Grimm resumed contact in the year following the end of hostilities. All three were also among those who provided care packages to the Klosterhaus in Lippoldsberg in the immediate post-war years. They responded to Grimm on his own terms as a representative of German conservative traditions, rightly true to his nation and people. ${ }^{49}$

In his first post-war letter to Blunden, Grimm rehearsed again the events in Lippoldsberg in the final days of the War. While little damage had been done, three shells had fallen in his garden and three in the Klosterhaus. There were no casualties, but the explosions caused Grimm significant hearing loss. His deafness stayed with him for the rest of his life. He also

48 Heuser to Grimm, 17.04.1946, DLA - A: Grimm / Amerika: Grimm, Heuser to Grimm, 1935-1949.

49 The reception of care packages was a prominent theme of Grimm's correspondence with friends abroad in the early post-war years, demonstrating, among other things, the complications involved in the re-establishment of postal services with Germany after the War. See, for example, Grimm to Heuser, 24.06.1946, 6.08.1946, 4.09.1946, 4.10.1946, I5.11.1946, I6.12.1946. 4.01.1947, 31.03.1947, 14.04.1947, DLA A: Grimm / Amerika: Grimm an Heuser, 1935-1959. 
reported that Dennis Thompson had passed through Lippoldsberg in the autumn of 1945 , spending a night at the Klosterhaus. Thompson was Grimm's first international guest after the War. ${ }^{50}$ These contacts proved important for Grimm, who rarely left Lippoldsberg in the post-war years. They not only provided him with an English-speaking audience for his analysis of Germany's situation, but also reconnected him in a practical manner with current affairs by providing him with access to and in some cases even regular subscriptions to English-language publications. Grimm enjoyed a subscription to the weekly edition of The Times from the end of 1947 through to 1954 thanks to Dennis Thompson. ${ }^{51}$ Heuser also kept him supplied with newspaper articles and magazines in the late 1940s, ensuring, for example, that he regularly received the World Report. ${ }^{52}$ Grimm thus remained reasonably well informed not only of what was going on in the world, but also of the opinions in the press of Germany's erstwhile enemies.

Grimm emphasised the importance of access to the foreign press also in the light of the doubts he entertained regarding the licensed press in Germany. In Grimm's eyes, the latter was aimed at indoctrinating the German people with an ideology that was, at best, misguided and more often than not a deliberate effort to undermine the German people. Given that his own convictions often ran counter to the positions he encountered in these publications, he was more than ever convinced of the need to provide his contacts abroad with information on the 'true' situation. The traffic in publications was not, therefore, one way: Grimm also ensured that Heuser and Blunden, among others, received copies of articles and recommendations for books that would provide them with insight into Germany's situation. ${ }^{53}$ In June 1947, Grimm wrote to Heuser, suggesting that

so Grimm to Blunden, undated letter in 1946, DLA - A: Grimm, Grimm to Blunden, 1939-1949.

5I Thompson to Grimm, I7.12.1947; Thompson to Grimm, 2.04.1954, DLA - A: Grimm, Thompson to Grimm, 1936-1958.

52 Grimm to Heuser, 24.08.1947, DLA - A: Grimm / Amerika: Grimm to Heuser, 1935-1959.

53 For example, Grimm to Heuser, I4.08.1947, DLA - A: Grimm / Amerika: Grimm to Heuser, 1935-1959. 
the problems in Germany were the result of initiatives of a small number of left-leaning men and women, both Germans and representatives of the Allied occupiers, to distort attitudes towards Germany's recent past in order to profit from the present. The licensing system for the press and publishing houses was little more than a propaganda initiative designed to present the Germans with a one-sided view of their situation and thus bend them to the ill-begotten goals of this group. The majority of honest German commentators were deliberately silenced with no publications available to represent their positions. The possible partial exceptions, as far as Grimm was concerned, were Die Zeit and Die Welt, and his positive inclinations towards these newspapers also subsided in the years to come. ${ }^{54}$

Grimm received regular visitors in Lippoldsberg in these years, including colleagues, friends, and passers-by. His availability to travellers remained a priority throughout the rest of his life. It was part of the responsibility he assumed in his self-appointed role as a spokesman for the German people. And the impressions he gained of life in Germany from his visitors informed his reports to correspondents abroad. Thus, he wrote to Heuser on 4 th September 1946:

There have been many visits. And the visitors want answers, which I am unable to provide. It saddens me continually to see these young people in dyed uniforms, only some of whom have families and homes and whose prospects are so miserable and who, furthermore, have been forced again and again to take the blame. I am astonished by the composure with which these things have been borne. ${ }^{55}$

Grimm's accounts of the real life stories of his visitors emphasised German suffering, both material and psychological, at the hands of the Allied occupiers and, later, Adenauer's government. As he became more and more convinced that Bolshevism was gaining the upper hand in Germany, it became increasingly necessary in his eyes that men in England and America gain an insight into conditions in Germany, as he understood them. These

54 Grimm to Agnes Miegel, 25.02.1947, DLA - A: Grimm, Grimm to Miegel, 1933-1959.

55 Grimm to Heuser, 4.09.1946, DLA - A: Grimm / Amerika: Grimm to Heuser, 1935-1959. 
were caused by the misguided government of the occupation authorities on the one hand and left-leaning Germans working under the label of democracy on the other. The latter represented, according to Grimm's estimate, about one fifth of the overall population, and three quarters of these were politically misguided. ${ }^{56}$

In 1947 Grimm also began gathering information from colleagues to send to Heuser. Responding to Grimm's request for news he could pass on, ${ }^{57}$ on 9 th November 1947 , Kolbenheyer described the situation in his home in Sölln directly after the War, in which American personnel were billeted.$^{58} \mathrm{He}$ expressed optimism regarding the outcome of his 'denazification', which continued to hang over him until its final, negative resolution towards the end of $1948 .{ }^{59}$ In a second letter, however, written the same month, Kolbenheyer articulated a sense of victimhood. He claimed that no one had formally accused him of anything and expressed incomprehension at a process which placed the responsibility on the Germans to prove their innocence. ${ }^{60}$

By the end of 1947, the process was well underway, although almost another year would pass before Kolbenheyer appeared before a tribunal. He was unable to view himself as a criminal, having never broken a law or been directly involved in the Nazis' crimes during the War. He viewed the process as agitation against him with its origins in the press. His conviction that the attacks amounted to an organised campaign against what he stood for in the German Volk echoed Grimm's accusation that Germany's cultural life and the public sphere were dominated by individuals seeking revenge

56 Grimm to Heuser, I5.II.1946, DLA - A: Grimm / Amerika: Grimm to Heuser, 1935-1959.

57 Grimm to Kolbenheyer, 3.11.1947, DLA - A: Grimm, Grimm to Kolbenheyer, 1933-1959.

58 Kolbenheyer and his wife had been forced to leave their house in Sölln altogether in 1946 .

59 Kolbenheyer to Grimm, 9.II.1947, DLA - A: Grimm, Kolbenheyer to Grimm, 1946-1959.

60 Kolbenheyer to Grimm, 27.11.2947, DLA - A: Kolbenheyer to Grimm, 1946-1959 in response to Grimm to Kolbenheyer, I5.II.1947, DLA - A: Grimm, Grimm to Kolbenheyer, 1933-1959. 
for their suffering under the Nazis. This view only served to strengthen Kolbenheyer's belief in the rightness of his völkisch worldview:

Denunciations were easy on German soil against anyone whose name appeared on a 'black list,' even where they were false, unmerited and laughable. With such actions of revenge personal victims are needed. I have the distinction (I use the word in all seriousness) of belonging to these victims. [...] Abroad, the necessary maturity is still lacking for a reasonable response to the propaganda of hate and revenge and for recognition that this second war was a very clever action in favour of a mercantile global imperialism. ${ }^{61}$

Kolbenheyer claimed that he was targeted because of his poem 'Der Führer'. The poem, he explained to Grimm, concerned Hitler's emotions as, in tears, he thanked heaven for his acceptance as a volunteer in the German army in 1914; the poem was not, Kolbenheyer claimed, an endorsement of later Nazi actions. Kolbenheyer continued in the same defensive tone:

I never accepted an office in the Nazi period, turned down a call to a university professorship, refused official invitations (Weimar) in spite of repeated urgent requests for my attendance (a Ministerial Director once sought me out specially). And I also know that the high officials viewed me with suspicion. Naturally I never had direct relationships with these men. In short, I know as little as anyone else what they can be holding against me. ${ }^{62}$

Given his long-standing contacts with a number of leading Nazis, not least his engagement with Rust over the reconstitution of the Literature Section of the Prussian Academy of Arts in 1933, Kolbenheyer's version of his recent past was somewhat disingenuous. His avoidance of the NSDAP's annual literary festival in Weimar was almost certainly not an ideological protest, but the result of his general dislike of such events, a sentiment he explained to Grimm in 195I when declining his invitation to the Lippoldsberger

6I Kolbenheyer to Grimm, 27.11.1947, DLA - A: Grimm, Kolbenheyer to Grimm, 1946-1959.

62 Kolbenheyer to Grimm, 27.11.1947, DLA - A: Grimm, Kolbenheyer to Grimm, 1946-1959. 
Dichtertag. ${ }^{63}$ With regard to his academic ambitions, in 1944 Kolbenheyer was offered the honorary direction of the newly created Paracelsus Institute in Villach. By this point in the War, this project existed in little more than name, and never became reality. ${ }^{64}$

The private exchange of letters with colleagues allowed Kolbenheyer and Grimm to articulate their personal versions of their history; in the articulation they were able to create a reality that underpinned their postwar positions that became the accepted truth in völkisch circles. In 1946, Grimm noted that he had not expected to resume contact with Kolbenheyer following their disagreement over the fate of Pezold and the Langen-Müller Verlag in 1938 . He observed, however, that the seriousness of the times made it imperative that old animosities should be forgotten and representatives of German literature, among whom Grimm rated Kolbenheyer one of the most important, should stand together. At stake was more than individual personalities; at stake was the soul of the German Volk, represented by its greatest contemporary writers. ${ }^{65}$

Through the Befreiungsgesetz, those subject to 'denazification' were judged by Germans in a civilian court (Spruchkammer). The judges consisted of confirmed anti-Nazis, in particular members of the reinstated political parties, especially Social Democrats and Communists, and German Jews who had been victims of Nazi anti-Semitism. While many Germans initially welcomed the changes enacted by this law in 1946 , most notably the transfer of partial responsibility for post-war judicial proceedings into the hands of the Germans themselves, for völkisch-nationalists the hearings were further evidence of the hunger of victims for vengeance. They were also seen as the betrayal of Germany by Germans, a continuation of the treason of the resistance, most notably those involved in the attempt to assassinate Hitler on 20 th July $1944 \cdot{ }^{66}$

63 Kolbenheyer to Grimm, 4.5.1950, DLA - A: Grimm, Kolbenheyer to Grimm, 1946-1959.

64 See discussion of the awards accorded to Kolbenheyer on pp. 133, 136-140.

65 Grimm to Kolbenheyer, I2.9.1946, DLA - A: Grimm, Grimm to Kolbenheyer, 1933-1959.

66 Grimm, Warum - Woher-Aber Wohin? pp. 485-506. 
These views were evident in their commentaries on Kolbenheyer's experiences. Unlike Grimm, Kolbenheyer had been a member of the NSDAP, having joined in 1938 following the German annexation of the Sudetenland. He appeared before Spruchkammer VI, situated in Thalkirchnerstraße in Munich, on 22nd and 27th October 1948, not long before 'denazification' trials were abandoned in the American sector. The chairman of the chamber, Wetzel, was described by Grimm in a letter to Heuser as a Czech Jew, who, following a period in one of the concentration camps, had subsequently run 'some sort of information office against the rest of us in London. ${ }^{67}$ An account of the trial was published in Der Weg-Monatshefte zur Kulturpflege und zum Ausbau, a journal published in Buenos Aires that provided one of the first organs for völkisch-nationalist writing in the years immediately after the War. Here it was suggested that Wetzel, supported by the public prosecutor, von Moßner, launched an offensive against Kolbenheyer that was 'unwürdig und haßerfüllt', irresponsibly motivated by prejudice and 'unclouded by any factual knowledge. ${ }^{68}$ The same article also launched an attack on those writers, among them Alfred Döblin, Erich Kästner, Werner Bergengruen, Alfred Kerr, Heinrich Mann and Arnold Weiß-Rüthel, who provided statements in support of the case against Kolbenheyer. The comments made in the magazine are not only an example of the widespread consternation among Kolbenheyer's colleagues and friends regarding the case, but also their general opposition to the influence after 1945 of writers who had been exiled or suffered under the Nazis. ${ }^{69}$

The Spruchkammer verdict sentenced Kolbenheyer to I 80 days labour over two years. In addition, half his wealth was confiscated, set at a sum of DM 287,000, and he was placed in Group Two, Aktivisten, the second highest category of Nazi criminal. It also placed a five-year ban on his professional activity, preventing the publication of any of his works until

67 Grimm to Heuser, 8.II.1948, DLA - A: Grimm / Amerika: Grimm to Heuser, 1935-1959

68 Eberhard Fritsch, 'Der Prozess Kolbenheyer' in Der Weg-Monatshefte zur Kulturpflege und zum Ausbau, 3. Jahrgang, Juli 1949, 7. Heft (Buenos Aires: Dürer-Verlag), p. 490. Ibid. 
1953. In spite of the widespread consensus that 'denazification' had failed to achieve the Allies' goal, namely the elimination of 'militarism and Nazism', and the removal of 'all Nazi and military influences from public institutions and the cultural and economic life of the German people, ${ }^{70}$ for Kolbenheyer the repercussions of the process were significant. ${ }^{71}$ In his final statement before the court, he protested his uncompromised honour. He said that he had submitted himself to the 'denazification' process as a German citizen obliged to follow the existing laws, in spite of his doubts about their validity. During the trial, he declared, he had been the subject of invective and conjecture. His attackers had used the proceedings as an opportunity to discredit his life's work. His concluding words emphasised his belief in the wider historical significance of his case:

Those standing in judgement should bear in mind that the court is not operating in this case solely within the sphere of political justice, but above all in an intellectual, historical forum, which also has resonance beyond the German nation, in an intellectual, historical court therefore, that has international significance. I am convinced that the judgement that is pronounced will not be forgotten quickly. ${ }^{72}$

These words were circulated to Kolbenheyer's sympathisers by Otto Zierlik, another Sudeten-German and one of his most loyal supporters in these years.

Kolbenheyer was right to believe that history would remember the verdict passed by the court. Although it was reduced on appeal, placing him in group three - 'Mitläufer' - his trial and the initial verdict fundamentally informed Kolbenheyer's relationship with the post-war German order. The outcome of his 'denazification' gained him considerable public sympathy. In the right-wing and nationalist press he was praised for emerging with

70 Quoted in Reichel, Vergangenheitsbewältigung, p. 30.

7I Copy of Kolbenheyer's summing up reproduced by Otto Zerlik and sent to friends and enquirers, including Kolbenheyer's publisher, the Langen-Müller Verlag in Munich. In sending it, Zierlik emphasised the private nature of the document; it was not, he emphasised, for public distribution. DLA: Otto Zierlik to Albert Langen - Georg Müller Verlag München, 1948-I949.

72 Ibid. 
his principles uncompromised. Significantly, however, as well as articles in right-wing organs like $\mathrm{Der} \mathrm{Weg}^{73}{ }^{73}$ several mainstream German newspapers also condemned the proceedings both at the time and long afterwards. On the occasion of Kolbenheyer's death in 1962 , the trial was referred to, for example, in the national daily newspaper Die Welt as a 'tragi-comedy'; the Mannheimer Morgen described it as a 'farce' as late as $1978 .{ }^{74}$ In addition, the Kolbenheyer Society was established in $195 \mathrm{I}$ by his supporters in response to the negative outcome of the author's denazification trial. Its aims were twofold: to promote his work and to provide him with moral and material support as he faced the five-year ban on pursuing his profession and the financial problems this caused him. ${ }^{75}$

As he did with Kolbenheyer, Grimm also established regular correspondence with Agnes Miegel in the years immediately after the War. Previously known to each other principally through their positions as Senators of the Literature Academy in the 1930s, after the War their friendship was fuelled by a period of intensive letter writing in the late 1940 s. Grimm sought to provide assistance for the 'wohl grösste lebende Dichterin', as he referred to Miegel in a letter of 3 Ist January $1947,{ }^{76}$ his second to her following her forced flight from her home in Königsberg, East Prussia, in 1945. Crossing the Baltic Sea, she and her companion, Elise Schmidt, were interned in a Danish camp on an island in Jutland. Eventually the two women were released to Apelern in the British occupation zone. They were provided with a room in a castle belonging to the Münchhausen family, relations of Miegel's old friend Börries von Münchhausen, who had committed suicide in the final weeks of the War.

Fritsch, 'Der Prozess Kolbenheyer'.

'Seine Zeit machte ihn gefährlich: Zum Tode Erwin Guido Kolbenheyers' Die Welt, 16.4.1962; 'Prophet der deutschen Innerlichkeit' Mannheimer Morgen 31.12.1978/I.I.1979.

75 Pamphlet circulated by the Kolbenheyer Gesellschaft dated July I956; Newsletter of the Kolbenheyer Gesellschaft, June 1962; also 'Zum Thema Literatur und Monopol' Frankfurter Allgemeine Zeitung, 17.7.1957. All in DLA - Erwin Guido Kolbenheyer: Wirkungsgeschichte.

6 Grimm to Miegel, 31.01.1947, DLA - A: Grimm, Grimm to Miegel, 1933-1959. 
Grimm's correspondence with Miegel further demonstrates the role he increasingly played after 1945 as a source of advice and a coordinator of the networks vital for providing likeminded individuals on the right with information and support as they sought to negotiate the new political climate after the War. They were helped by the fact that the 'cleansing' of the German bureaucracy after 1945 was only partial, allowing a number of old friends and colleagues to retain positions of responsibility, giving their völkisch literary acquaintances access to officialdom.

In February 1947, Miegel expressed her growing uncertainty regarding the 'denazification' process in the British zone. ${ }^{77}$ Grimm responded to Miegel's questions by passing them on to Ministerialrat Zierold, who had previously been in charge of the Prussian Academy of Arts in the Prussian Ministry of Culture. Advising Miegel to wait and see how events developed, Grimm's letter also highlighted the differences between the zones of occupation, which further added to the impression that the 'denazification' process was arbitrary and unfair. ${ }^{78}$ Writing this letter, Grimm was already more pessimistic than he had been a few weeks earlier about the potential reception of Miegel's work, although his faith in her position among the most important German literary figures remained undiminished. ${ }^{79} \mathrm{He}$ was convinced, for example, that the editors of Die Zeit and Die Welt would have accepted her work if they had been left to their own devices. As it was, Grimm could only assume they were operating under pressure from the British occupation authorities. ${ }^{80}$

Zierold responded to the enquiry regarding 'denazification' with a recommendation to lie low. Miegel told Grimm that she intended to follow his advice, showing little urgency to start publishing again. ${ }^{81}$ Miegel's case was not dissimilar to that of Kolbenheyer, although the difference in their genders had a bearing on their experience of the Nazi ideology. But even

77 Miegel to Grimm, 21.02.1947, DLA - A: Grimm, Miegel to Grimm, 1933-1959.

78 Grimm to Miegel, 25.02.1947, DLA - A: Grimm, Grimm to Miegel, 1933-1959.

79 See for comparison, Grimm to Miegel, 31.01.1947, DLA - A: Grimm, Grimm to Miegel, 1933-1959.

80 Grimm to Miegel, 25.02.1947, DLA - A: Grimm, Grimm to Miegel, 1933-1959.

8I Miegel to Grimm, 28.3.1947, DLA - A: Miegel to Grimm, 1933-1959. 
here, Miegel's life was not typical of German women of her generation, not least because she enjoyed the privileges that success and renown as a poet brought. This meant that she had access to membership of a number of male-dominated literary institutions, including the Literature Academy. Like Kolbenheyer, she came from the territorial fringes of the German Reich in Eastern Europe, although East Prussia, while cut off after the First World War by the Polish Corridor, was part of Germany in Miegel's lifetime up to 1945. And like Kolbenheyer she had made a name for herself already in the first decade of the twentieth century. In Miegel's case, she had been one of the leading proponents of the revival of the German ballad, alongside Münch hausen. She was eventually cleared of involvement in the Nazi regime in 1949, although she had joined the NSDAP in 1940. Not unlike Kolbenheyer's emotions at the annexation of the Sudetenland, this had been in gratitude for the reconnection of her East Prussian homeland with the rest of the Germany following the German invasion of Poland. ${ }^{82}$

In Königsberg Miegel had been involved particularly in the activities of the BdM. Her post-war correspondence with Grimm suggests a naive attitude towards her involvement with the Nazis and reinforced Grimm's faith in the existence of a healthy, pure National Socialism. According to Miegel, the sense of community and service to the Volk survived to the end of the war among the Germans in East Prussia. ${ }^{83}$ Her repeated accounts demonstrate how little the 'denazification' process touched her personal experience of the Nazi period:

[...] I was not involved in 'Party work'. I did, however, stand close to the dear young people in the BdM, the Arbeitsdienst and the Landjahr, as well as those women, so courageous to the very end and always helpful, in the Frauenschaft and the NSO. In particular, in our border region in the East, I met with so much human competence, so many pure, healthy and enthusiastic hearts, so many willing workers and helpers - literally until death, and so much composure in the face of the bodily and spiritual need of the downfall - that I can only think of these people with loyalty and love, yes with admiration. The survivors among them now have to wrestle so hard to be

82 Sarkowicz and Mentzer, Literatur in Nazi-Deutschland, p. $28 \mathrm{r}$.

83 Miegel to Grimm, 21.02.1947, DLA - A: Grimm - Miegel to Grimm, 1933-1959. 
allowed to serve the land that had the greatest meaning for them in the world, the land that they believed they were serving with all their hearts. ${ }^{84}$

Miegel's attitudes towards the Third Reich were therefore based on her own experiences, rather than the public discourse disseminated by the Allies. Her response to post-war Germany was, unsurprisingly, also bound up with the experience of expulsion from Königsberg, her personal suffering binding her to that of her Volk. This suffering was not only ignored by the victorious powers, but exacerbated by the worry caused by 'denazification' and controls over the publishing industry that threatened her livelihood. ${ }^{85}$

The overall failure of the 'denazification' process had far-reaching consequences for the relationship of völkisch-nationalist and right-wing thinkers with the post-war structures in Germany. They did not understand the process as it has been seen by subsequent historians like Fritz Stern, who suggested that active memory of the Nazi past was pragmatically suppressed in West Germany in the post-war era in favour of social and cultural peace that allowed social cohesion and the development of democracy at home and rehabilitation abroad. ${ }^{86}$ While there is truth in Stern's analysis, memory of the immediate past remained very much alive, often in unofficial forms that were not imposed from outside; indeed, as the German population sought to recover materially and psychologically from the experience of the War, engagement with what had gone wrong was unavoidable. Far from forgetting, völkisch-nationalists were determined that the memory of what had gone before needed to be remembered correctly. They emphasised 'denazification' and 're-education' as Allied propaganda. In the long run, some of them argued, this would be detrimental not only to Germany, but to Europe and the 'white race' as a whole.

Paradoxically, at the same time the quiet subsidence of the 'denazification' process noted by Stern provided völkisch-nationalists with their opportunity for integration into West German literary life. It created a situation in which those on the far right could be absorbed into

84 Miegel to Grimm, 3.08.1947, DLA - A: Grimm - Miegel to Grimm, 1933-1959.

85 Miegel to Grimm, 8.04.1947, DLA - A: Grimm - Miegel to Grimm, 1933-1959.

86 Fritz Stern, Dreams and Delusions., p. 16. 
the new Federal Republic. Moreover, their efforts to negotiate 'denazification' strengthened their networks, laying the foundation for ongoing cooperation throughout the I950s. Völkisch-nationalists, however, failed to recognise the advantages the situation brought them, the short-term disadvantages of 'denazification' instead fuelled their wider grievances at Germany's situation. These also focused, for example, on the destruction of German cities and the expulsion of Germans from territories in Eastern Europe in 1945 and 1946.

\section{Re-education}

Alongside 'denazification', initiatives introduced to re-educate the German population after the War contributed to the frustrations of völkisch writers during the years of military government. The principles that governed the re-organisation of German cultural life under the victorious powers were agreed at Potsdam in the summer of 1945 and were aimed at the removal of National Socialist and militarist tendencies in German life, viewed by the Allies as the root of German aggression in the modern period. 'Re-education' was, therefore, the result of the prevailing understanding and, at times, prejudices regarding Germany. A study commissioned by the US Military Government, for example, explained the rationale behind the 're-education' measures, highlighting the danger that German culture was liable to create an atmosphere of aggression. ${ }^{87}$

As a result measures were taken to control cultural production in all four occupation zones. Initially, these included a complete ban on publishing, which was gradually eased through a system of licensed publishing houses, newspapers and magazines. Until the middle of 1947 ,

87 Hansjörg Gehring, Amerikanische Literaturpolitik in Deutschland, 1945-1953: Ein Aspekt des Re-Education-Programms (Stuttgart: Deutsche Verlags-Anstalt, 1976), p. 17. 
the four powers cooperated closely in this process. All the same, the wide scope of the 're-education' process meant that it was by its very nature difficult to manage, aiming at the transformation of the moral, cultural and political values prevailing in Germany. ${ }^{88}$ While the nationalist historian Caspar Schrenck-Notzing was among the first to refer to 're-education' measures as 'brainwashing' (Charakterwäsche), Ernst Fraenkel described the process as 'salutary coercion, intended to help the German people in their attempt to restore their connection to a common cultural inheritance indicated by the words Jerusalem, Athens and Rome, which had been broken by their relapse into barbarism during the years $1933-1945 .{ }^{89}$ Fraenkel's comments highlight an area of misunderstanding between the policy makers of the occupation authorities and völkisch commentators: the language of babarity and civilisation was open to multiple interpretations. For völkisch writers, the civilisations of ancient Rome and Greece were the products of the 'white' race. While few returned overtly to Alfred Rosenberg's interpretation of western civilisation as an Aryan accomplishment, Grimm and Kolbenheyer emphasised Germany's central role in protecting 'white' civilisation, which facilitated the idea of united Europe based on racial principles. ${ }^{90}$

Völkisch-nationalists compared 're-education' with the censorship and propaganda they had known between 1933 and 1945; frequently the measures were viewed as more restrictive than anything that had operated under the Nazis. Not only was the remaining German cultural production after

88 Harold Zink, American Military Government in Germany (New York: Macmillan, 1947), p. I47; Gehring, Amerikanische Literaturpolitik, p. I8.

89 Caspar Schrenck-Notzing, Charakterwäsche: Die amerikanische Besatzung in Deutschland und ibre Folgen (Stuttgart: Seewald, 1965), 176-178; cited in theintroduction to Karl-Ernst Bungenstab, Umerziehung zur Demokratie? Re-education-Politik im Bildungswesen der US-Zone 1945-1949 (Düsseldorf: Bertelsmann, 1970), p. II; on the 'Americanisation' of West Germany, see among others: Arnold Bergstraesser, Zum Problem der sog. Amerikanisierung Deutschlands, Jahrbuch für Amerikastudium, 176-178, 8 (1963), I8 and 21. All cited by Gehring, Amerikanische Literaturpolitik, p. 19.

90 Grimm, Warum - Woher - Aber Wohin?, pp. 21I-213; Kolenheyer, Sebastian Karst, vol. I, pp. 187-194. This reasoning also reflected the arguments used by Kolbenheyer in the 1920 s. See Chapter 2. 
the War suspended and restarted gradually under the control of the occupation authorities, but völkisch commentators saw a discrepancy between the restrictive measures adopted by the latter and the Allies' message of democracy and free speech. ${ }^{91}$

'Re-education' measures affected literary life in various ways. The identification and removal of literature felt to contain militarist, racist or National Socialist content from libraries and bookshops was seen by some to point to a continuation, with a new focus, of Nazi strategies. Licenses were granted to publishers and booksellers who had been cleared in the 'denazification' process and appeared committed to democratisation. Centralised distribution of paper resources also continued after the War, further limiting what could be published. In the Western zones this came to an end with the currency reform in 1948. Similarly, a centralised system was established to administer the copyright for German translations of books and plays in the canons of the victorious nations, selected because they were felt to promote suitable attitudes in the German population. Cultural centres run by the occupying powers were established, notably the American Houses in cities across the American zone, as well as new libraries containing works deemed suitable for Germany's democratic future. Arrangements were also made to ensure the free exchange of 'information and democratic ideas', as well as actors and artists, between the four zones. In addition, German initiatives were encouraged that sought a renewal of German culture along democratic lines. Thus, for example the Deutscher Kulturbund was established in East Berlin in August 1945 and the Kulturliga in Munich the following December. A number of magazines and journals were allowed, including Der Ruf, a project led by Alfred Andersch and Hans Werner Richter from August 1946 until its prohibition, in its original form, as a result of its 'nihilist' tendencies in 1947. Thereafter, Andersch and Richter were central to the formation of the influential, unofficial Gruppe 47, which sought a new German literature. ${ }^{92}$

91 See, for example, Grimm, Warum - Woher - Aber Wohin?, p. I80.

92 Dieter Breuer, Geschichte der literarischen Zensur in Deutschland (Heidelberg: Quelle \& Meyer, 1982), pp. 239-240; Gehring, Amerikanische Literaturpolitik, p. 40 
With the onset of the Cold War, 're-education' initiatives were increasingly less of a priority in the West. ${ }^{93}$ This environment also provided völkisch-nationalists, emphasising their anti-Bolshevik credentials, with an opportunity to revive their careers. Nonetheless, in spite of the freedom they enjoyed under the Basic Law of the Federal Republic, the initial limitations on published output imposed by Allied policies fundamentally shaped the völkisch interpretation of the post-war order as a whole. They presented the Allies' policies as the reintroduction of censorship; the strategic publication of works that were felt to promote democracy, particularly in the American zone, led to accusations of propaganda.Völkisch-nationalists shared a more widespread feeling among Germans that Allied policies represented the double standards of the victors in the recent conflict: the use of undemocratic methods in defence of democracy. This has been noted by a number of subsequent scholars. Dieter Breuer observes, for example, that the initial idealism of democratic education in all four occupation zones gave way after 1947 to a more ideologically determined message of anti-Capitalism or anti-Communism in the east and west respectively, helping to undermine further the credibility of the measures introduced by the Western Allies. ${ }^{94}$

Kolbenheyer reflected on the Herculean task of the 'denazification' and 're-education' programmes in his autobiographical novel, Sebastian Karst. The fact that the criticisms he raised echoed problems that were widely recognised, namely that 'denazification' in the late I940s led to a shortage of skilled workers in some areas, served to endorse his overall point of view, and demonstrates how völkisch commentators were able to draw on widely held concerns to support their position in the early postwar era. Kolbenheyer wrote:

Idleness everywhere, in the trades, in intellectual life. Industry and businesses were paralysed, the 'cleansed' schools hardly had any teachers left, no teaching materials, no schoolrooms; in the universities only a fraction of those who were clammering to study were allowed to enrol; foreigners, however, flooded the universities. Those who had

93 Breuer, Geschichte der literarischen Zensur, p. 240.

94 Ibid., p. 239. 
belonged to the Nazi Party were excluded from all higher activities. Black, grey, white lists of authors were compiled, the libraries were also 'cleansed'. Karst belonged among the ostracised, alongside names like Sven Hedin, Ludendorff, Hamsun, Binding, Grimm, Jünger, Chamberlain. The names of these men were erased in the catalogues of the lending libraries and at least some of their works removed from the shelves. A committee of servile ignorants, or those who wanted to vent their spleen, took the decisions; the names of these dreadful individuals remained unknown. In musical life the same disgraceful situation reigned as in the literary sphere. ${ }^{95}$

Kolbenheyer's reflections, written in the course of the 1950s, suggest that the grievances of the years of military government added to more general resentments and continued to colour völkisch responses to the FRG, which came to be seen as the product of Allied policies. Thus, while the material conditions of most West Germans improved rapidly, the memory of the immediate post-war years continued to have a defining impact on völkisch responses to the transformations that occurred in Germany in the course of the 1950s. It is telling that Kolbenheyer emphasises the endorsement he gained from being targeted by policies he believed illegitimate and destructive of German culture. In his writings, German suffering was raised to the level of martyrdom in the name of the German Volk.

Grimm's perspective was similar. He described the inspection of his private library by a CIC official, who noted that Grimm possessed a large number of books that had been banned by the Nazi government. For Grimm, this was not only further proof of his independence during the regime, but also of the false understanding of the regime spread by Allied 'propaganda' after the War. He told the official that he knew nothing of banned books during the Third Reich from his own experience; no one had ever prohibited him from reading anything. By contrast, however, he went on to describe his concern at the lists of banned books drawn up by the victorious Allies, both those made public and the alleged unofficial lists of the Americans. Grimm claimed that he had gained access to the latter and found his name included on them. ${ }^{96} \mathrm{He}$ presented a similar argument in response to the lists of literature to be removed from libraries 
and booksellers drawn up by the military occupiers. Again, the efforts to shape German cultural life after the War put Allied measures on a par with those previously adopted by the Nazis and undermined any moral credibility they might claim in the eyes of Grimm and his fellow völkisch commentators. $^{97}$

While Grimm's work appeared on some early lists of books to be removed from libraries and booksellers' shelves in the Soviet zone, there is little evidence to suggest that in the long run its publication was adversely affected by censorship measures in the FRG. This suggests that the actual impact of Law No. 5 of the Allied High Commission was low. This legislation was passed on 23 rd September 1949 and remained in power until the Occupation Statute was lifted in 1952. It covered the press, radio, reporting and centres of entertainment in West Germany, prohibiting work that could be considered damaging to the reputation of the Allies or a threat to their security. It established mechanisms for the control and, if necessary, confiscation of works that contravened these terms, stipulating that a copy of every publication be made available to the relevant German or Allied officials. ${ }^{98}$ This was, however, balanced out in the long run by Article 5 of the Basic Law of the FRG, ratified on 23rd May 1949, which established freedom of opinion and the press, as well as teaching and research, and prohibited censorship. ${ }^{99}$

The appearance of their names on lists of undesirable literature in the various zones of occupation in 1946 and 1947 nonetheless served to endorse the arguments of volkisch commentators that they were the targets of a deliberate campaign being waged against them by the occupation authorities. In April 1946, the Verwaltung für Volksbildung in the Soviet occupation zone published a provisional list of 'auszusondernde Literatur'. The preamble stated that the list was intended as a guide for staff in relevant positions in fulfilling the cultural requirements of the military government, according to which 'All works with fascist or military content are

97 Ibid.

98 Breuer, Geschichte der literarischen Zensur, p. 248.

99 Ibid., p. 248. 
to be withdrawn, those that contain expressions of political expansionism, represent the National Socialist racial teachings or oppose the Allies. ${ }^{100}$ While the list contained around I5,000 titles, it was emphasised that it should not be considered an exhaustive bibliography. In particular, works that were not necessarily to be considered National Socialist or militarist in general, but which contained specific sections that might cause alarm, were to be examined at a later date, as well as those works that remained in wartime storage: 'The fact that a book does not appear on this list is by no means valid justification for the director of a library or a bookshop to allow the lending or sale of a book with negative tendencies. ${ }^{\prime 101}$ This initial list concentrated, as explained in the preamble, on works published during the Third Reich. With the exception of his 1932 speech, 'Von der bürgerlichen Ehre und bürgerlichen Notwendigkeit', which was also included, only editions of works by Grimm published between 1933 and 1945 were present on the list, including the 1944 edition of Volk obne Raum released by Bertelsmann. ${ }^{102}$ Similarly, Kolbenheyer's major works were not listed, only four published speeches, including Der Lebensstand der geistig Schaffenden und das neue Deutschland that had been banned in $1934 .{ }^{103}$

Similar lists were drawn up in all four zones. On I2th July 1946, the American newspaper, Die Neue Zeitung, reported that the American military authorities had issued a list of undesirable literature following the publication of the Soviet list. ${ }^{104}$ The principles for the selection of works were more or less the same: all works representing fascist, anti-democratic, pan-German and imperialist points of view were to be removed. The same applied to works against the United Nations or any of the occupation powers. Nonetheless, as the article pointed out, while the Soviet list

Ioo Deutsche Verwaltung für Volksbildung in der sowjetischen Besatzungszone, Liste der auszusondernde Literatur, vorläufige Ausgabe nach dem Stand vom I. April 1946 (Berlin: Zentralverlag, I946), p. 3.

IOI Deutsche Verwaltung für Volksbildung, Liste der auszusondernde Literatur, p. 4.

IO2 Ibid., pp. I46-I 47 .

I03 Ibid., p. 223; see Chapter 3.

I04 'Liste der I000' in Die Neue Zeitung, 12.07.1946, DLA - A: Grimm/ Nachkriegsverbote; Konv. Listen der unerwünschte Bücher und Berichte darüber 1946/ 47. 
included 15,000 titles that of the Americans was limited to I000. It was presented as an illustrative sample rather than exhaustive bibliography, leaving decisions regarding individual works to the discretion of booksellers and librarians. As the Neue Zeitung observed, the list did not include works by Hitler, Goebbels and Mussolini. Nonetheless, it was self-evident that these should be withdrawn from circulation. Perhaps more confusingly, it failed to provide guidance on borderline cases like Ernst Jünger and Oswald Spengler, prohibited the entire catalogues of authors like Bartels, Dwinger and Joseph Magnus Wehner, and included only specific books by Kolbenheyer, Grimm and Frenssen, among others. Friedrich Griese and Hanns Johst were both subject to a blanket prohibition in the American list, but remained largely tolerated in the East. ${ }^{105}$

The Neue Zeitung noted the American list's lack of clarity, commenting that its attempt to avoid prescription in favour of a more open approach left too many questions open. It also acknowledged the problem of such lists in a democratic system, but emphasized their necessity, highlighting the paradoxical nature of re-education:

\begin{abstract}
Anyone who fundamentally supports freedom of expression will find no joy in any index. Sadly, a large proportion of the German people is so strongly infected by the National Socialist mass psychosis that it must now also accept an intellectual paternalism. [...] It is to be wished that the time is no longer far off in which all bans in the publicistic and literary spheres will be superfluous. National Socialist agitation will come to have curiosity value as the documentation of human stupidity, and pamphlets against the 'racial enemy' will be automatically proscribed as a result of their ridiculousness. ${ }^{106}$
\end{abstract}

It was also unclear how long the lists would apply to the living writers whose names appeared on them. The article in the Neue Zeitung suggests that the American authorities assumed that the lists would eventually become redundant as the demand for the works of undesirable writers diminished as the population became more enlightened. ${ }^{107}$

I05 Ibid.

Io6 Ibid.

I07 Ibid. 
A cutting of this article can be found in Grimm's papers, alongside further press clippings on the subject. His correspondence also supports the impression that he relied to a large degree on the press, on hearsay and informal exchanges for information on the situation. In his correspondence in 1946 and 1947 in particular he sought to keep track not only of his own works, but also those of his colleagues. His first post-war exchanges with Alverdes were dominated by his efforts to discover first, where lists had appeared in the American zone, in which they both lived, and who was responsible for them, and second whether his own works were included. On 3rd May 1946, Alverdes wrote to Grimm:

More exact information about the sales ban is unavailable. That such lists exist is, however, without doubt. Nonetheless, Rütten und Loening recently informed me that they intend to launch a legal appeal through their lawyers against the ban on the Pfeiferstube. Most of RudolfG. Binding's works are also affected by this ban. You can see, therefore, that we are not dealing with a local Munich list. ${ }^{108}$

Similarly, as they sought to uncover the implications of the Allied policies for their work, Alverdes reported to Grimm that Carossa's autobiographical work, Die Geheimnisse des reifen Lebens, had been banned. He suggested the underlying reason for Carossa's problems was his involvement in the Europäische Dichterunion established by Goebbels; he noted that at the most only the small section of his autobiography that dealt with the War could be counted as in any way militarist. ${ }^{109}$ In responding, Grimm asserted, moreover, that the Dichterunion had been largely positive, the only drawback being the fact that it had been an initiative of Goebbels. ${ }^{110}$

The measures introduced to 'cleanse' the German intellect of Nazi ideology enjoyed a mixed reception in the press, from the measured support of the Neue Zeitung to opposition and frequently incomprehension. The Deutsche Rundschau considered the vocabulary used in presenting the list drawn up by the Magistrat in Berlin in cooperation with the Kammer der

I08 Alverdes to Grimm, 3.05.1946, DLA - A: Alverdes, Alverdes to Grimm, I937-195I.

I09 Alverdes to Grimm, 18.03.1946; 3.05.1946 in Alverdes to Grimm, 3.05.1946, DLA A: Alverdes, Alverdes to Grimm, 1937-195I.

in Grimm to Alverdes, 5.04.1946, DLA - A: Grimm, Grimm to Alverdes, I934-1953. 
Kunstschaffenden and the Kulturbund zur demokratischen Erneuerung Deutschlands, suggesting that 'auszusondern' was not very different from 'Verbot' or 'unerwünscht', the latter used by Goebbels' Propaganda Ministry in constructing the black lists of the Third Reich. The same article also noted that Hans Grimm, for example, had been included in this list, with nine works specifically named, among them Volk ohne Raum. The journal questioned his inclusion, alongside that of a large number of fellow writers, arguing: 'All these writers, who offer real substance, should be removed from the lists of banned works as quickly as possible. For the sake of the lists, which will come to determine the style of cultural politics in a democratic epoch!'11

The problem with the production of lists of undesirable literature mirrored more general problems that characterised 're-education' initiatives across Germany: while the lists were seen as necessary for realigning German culture towards democracy, their piecemeal publication and differences in style and emphasis laid the occupation authorities open to accusations of arbitrariness. Moreover, opinions differed regarding the relative worth and Nazi content of the works of various writers, as the commentary in the Deutsche Rundschau demonstrates. ${ }^{112}$

In practice, it was often unclear to writers and publishers where restrictions on their works were imposed, why, and by whom. Legally, it also appears to have been difficult to gain an oversight of the process. ${ }^{113}$ The responses of writers to the inclusion of their names included incredulity and resentment. In mid-1946, Grimm was informed by acquaintances that an announcement had been made by the Hamburger Rundfunk informing listeners that Volk obne Raum was among the works to be removed from Hamburg's public libraries. In a letter to the radio station's Intendant,

II I 'Auszusondernde Literatur' in Deutsche Rundschau, Heft 7, October 1946, DLA - A: Grimm / Nachkriegsverbote; Konv. Listen der unerwünschte Bücher und Berichte darüber $1946 / 47$.

II2 Ibid.

II3 See, for example, the correspondence regarding the ownership of the Rütten \& Loening Verlag in 1946, in particular Dr. jur. G. Greuner an Firma Rütten \& Loening, I5. April, I946, DLA - A: Grimm, Grimm to Alverdes, I934-1953. 
Grimm demanded to know where the ban on his work had originated. He warned that the suppression of his works would not only go down negatively in literary history, but would also ensure that an era in which Germans were allegedly searching for a new truth and new freedom would in fact appear less true and less free. ${ }^{114}$

Alongside expressions of resentment, however, a sense of defensive pride was also evident in the responses of Grimm and Kolbenheyer to the inclusion of their works on lists of literature that should be removed from circulation. Kolbenheyer noted: 'The index of banned works was not even complete, only the most obvious had been quickly included. At the same time, Karst would have had difficulty bearing it if his work had not been included in the ban. The unique cultural life of the German Volk was targeted; it was to be reduced to a level of civilisation that made it the last Volk of the [white] race - Morgenthau. ${ }^{115}$ Given their view of the measures introduced under the allied occupation as an attempt to undermine the German Volk, the desire to remove their works only served, in the eyes of the authors and their supporters, to endorse their importance for German culture. Grimm's criticisms were not aimed solely at the Allies, but also at those Germans who were prepared to enforce the post-war denazification and re-education measures. He denounced those of his compatriots who had cooperated with Germany's erstwhile enemies and thus betrayed the German people. ${ }^{116}$

The 're-education' measures presented völkisch-nationalists with the challenge in the immediate post-war years of finding licensed publishers prepared to produce their works. This further contributed to their sense of grievance at the post-war situation, but actually passed remarkably quickly, with a significant number finding outlets for their work by 1950. While Grimm was cleared in the 'denazification' process, his position under the occupation regime remained unclear. This became apparent, not least, in

II Grimm an den Intendant des Hamburger Rundfunks, 5.6.1946; copy sent to Paul Alverdes, 29.1I.1946, DLA - A: Alverdes, Grimm to Alverdes, 1946-1955.

II Kolbenheyer, Sebastian Karst, vol. I, p. 40I.

II6 Grimm to Alverdes, 27.2.1946, DLA - A: Grimm, Grimm to Alverdes, 1934-1953. 
his relationship with the Bertelsmann Verlag. Bertelsmann re-established its business relatively quickly, managing to convince the British authorities that it was untainted by association with National Socialism, although subsequent historical work has reassessed the firm's relationship with the Nazi regime, showing it in a less positive light. ${ }^{117}$ Like the 'denazification' of individuals, the licensing of publishing houses was more arbitrary in practice than official regulations suggested, and like 'denazification' it depended to a considerable extent on networks of support, having the right figurehead, and personal contacts. For Grimm, who had moved his work to Bertelsmann following his withdrawal from the LMV in 1938 , there was no reason to suppose that Bertelsmann would not continue to operate as it had in the Third Reich - a patriotic, conservative firm that profited from producing literature to support the German war effort - even if he was uncertain whether he wanted to remain involved with the firm. ${ }^{118}$

Grimm's attitude towards the firm displayed his failure to recognise the weakness of his position after the Second World War. Nonetheless, his assumption that he would continue to occupy a privileged position in the German literary landscape was also supported in the immediate postwar period by the efforts of leading members of staff, including the firm's Director, Heinrich Mohn, to cultivate Grimm alongside Vesper as a star author of the firm. Both lived relatively close to Gütersloh. Mohn wrote to Grimm as early as March 1945, stating that he hoped in the not too distant future to have my firm more or less completely operating again. ${ }^{119}$ It is also apparent from Grimm's correspondence with Pezold that Bertelsmann's staff remained in close contact with him after the War. On 27th September 1945, Grimm informed Pezold that Dessin, Bertelsmann's editor in chief, had visited him in Lippoldsberg. ${ }^{120}$ Grimm was swift to assure Pezold that he had made it clear that his favoured option was to rejoin him should he

I17 Saul Friedländer, Norbert Frei, Trutz Rendtorff, Reinhard Wittmann, Bertelsmann im Dritten Reich (Munich: Bertelsmann, 2002).

II 8 Grimm to Miegel, 31.01.1947 and 29.04.1947, DLA - A: Grimm, Grimm to Miegel, 1933-1959.

II9 Quoted in Friedländer et al., Bertelsmann im Dritten Reich, p. 516.

I20 Grimm to Pezold, 27.09.1945, DLA - A: Grimm, Grimm to Pezold, I938-I946. 
be able to revive the LMV, an ongoing subject of discussion after the War. ${ }^{121}$ Shortly after his visit to Lippoldsberg, meanwhile, Dessin was forced to the resign at Bertelsmann due to his membership of the NSDAP. He was replaced by Wolfgang Strauß, who continued to correspond with Grimm and Vesper. ${ }^{122}$

It has been suggested that Bertelsmann's efforts to court Grimm had pragmatic foundations. While too close an association with his name threatened to cause problems for the firm with the British occupation authorities, Grimm provided access to a large circle of significant conservative and nationalist authors now without a publisher, not least those who had previously published with Langen-Müller. No longer able to rely on the substantial income it had enjoyed from its war books, the possibility of acquiring the rights to works of writers who had been successful with the LMV appeared particularly appealing to Bertelsmann's managers. Many were regular visitors to Lippoldsberg. In 1946, moreover, Heinrich Mohn already sought to win Emil Strauß for the firm, telling him that he was simultaneously in contact with August Winnig and had already gained the commitment of Hermann Claudius and Rudolf Alexander Schröder. He added that he intended to contact Friedrich Bischoff, while Hans Grimm had agreed to talk to Wilhelm Schäfer, Joachim von der Goltz and Heinrich Zillich. ${ }^{123}$

Heinrich Mohn was forced to stand down as Director of Bertelsmann in April 1947 in the course of the firm's application for a licence to publish newspapers in the British military zone, although he remained active behind the scenes after he passed formal direction to his son Reinhard. ${ }^{124}$ One of Heinrich Mohn's last acts as Director was the formal termination of the firm's ties with Grimm. This does not appear to have been motivated by political

I2I See also Grimm to Pezold, I2.6.1945, 27.II.1945, I4.I2.1945, 29.12.1945, DLA - A: Grimm, Grimm to Pezold, 1938-1946; Gustav Pezold, 'Über den Verlag LangenMüller u. seinen Autor Erwin Guido Kolbenheyer', DLA - A: Alverdes, Gustav Pezold, versch.

I22 Friedländer et al., Bertelsmann im Dritten Reich, pp. 524-525.

I23 Ibid., pp. 544-545.

I24 In filling in his denazifacation questionnaire, Heinrich Mohn failed to declare his membership of the SS as a financial donor. Ibid., pp. 529-530. 
concerns, but by the personal slight Mohn felt he had received from Grimm, who had suggested that the publisher was driven by commercial rather than ideological commitments. ${ }^{125}$ From Grimm's perspective, his association with the firm had already ended in 1944 and Mohn's actions do not seem to have affected him unduly. Moreover, their correspondence remained businesslike in the years that followed, although there was no serious discussion of Bertelsmann continuing to publish Grimm's works in their subsequent letters. These focused on Grimm's purchase of the typeset manuscripts of his books. ${ }^{126}$ Also of concern to Grimm were the 7800 copies of his Englische Rede that had survived the War stored in the town hall in Gütersloh. Grimm's correspondence with the Book Section of the military government in the British occupation zone documents his efforts to gain possession of these remaining stocks in order to disseminate them to friends and acquaintances. ${ }^{127}$ In 1948 , however, there was still no decision and Grimm does not appear to have pursued the matter further. ${ }^{128}$

By 1950, Grimm's pessimistic analysis of the publishing landscape reflected his view of the situation of German literature as a whole. After several years of dissatisfied searching, and the publication of his Erzbischofschrift in 1950 by the Plesse-Verlag in Göttingen, he founded his own firm, the Klosterhaus-Verlag, in 1951. Grimm's concern to identify a suitable publishing firm was not limited to his own work. He also sought to alleviate both the material and intellectual frustrations of his friends and colleagues and intended that the Klosterhaus-Verlag should provide writers

I25 Ibid., pp. 530. See also Grimm to Miegel, 29.04.1947, DLA - A: Grimm, Grimm to Miegel, 1933-1959.

I26 Heinrich Mohn to Grimm, undated letter 1947; I3.I.1948 and 29.I.1948, DLA - A: Grimm, Heinrich Mohn to Grimm, 1947-1948.

I27 Grimm to the Book Section of the Military Government of the British Zone of Occupation, in which Gütersloh was located, I0.119147; 30.12.1947, DLA - A: Grimm - Grimm to Deutschland, Militärregierung, Book Section, Regional Staff 1947.

I28 Book section of the Military Government of the British Zone of Occupation, 6.or.1948 to Grimm, DLA - A: Grimm - Deutschland, Militärregierung, Book Section, Regional Staff, to Grimm, Hans, 1947; see also Mohn to Grimm, undated letter 1947; I3.I.1948 and 29.I.1948, DLA - A: Grimm, Heinrich Mohn to Grimm, 1947-I948. 
on the far right a practical solution to the problem of finding a publisher. ${ }^{129}$ Grimm's commitment to his völkisch colleagues reflected his sense of a duty towards 'German' literature, evident in his communications with Miegel. Early on in their post-war correspondence he raised the question of her financial situation and the question of gaining permission from the occupation authorities for the appearance of her work. He offered to put her in touch with Strauß at Bertelsmann. He continued to promote the firm as one of the few sensible options open to his colleagues. ${ }^{130}$

\section{Hans Grimm and the Extreme Right after 1945}

Völkisch writers were able to re-establish their careers quickly after the War. This was partly due to the unsystematic coordination of policies between the zones of occupation. More important, however, was the attitude of Germans themselves. As the Lippoldsberger Dichtertage in the post-war years demonstrated, members of the public did not necessarily identify Grimm and his colleagues as representatives of the regime; instead, for many, their situations mirrored the challenges that faced the whole country. ${ }^{131}$ Their works represented familiarity and continuity against a backdrop of change and uncertainty.

Völkisch books also remained on school curricula. On I6th November 1950, Annelies von Ribbentrop informed Grimm that her daughter was reading his Südafrikanische Novellen in school. It was, the widow of the former Nazi Foreign Minister suggested, a good sign. ${ }^{132}$ In 1954, she again

I29 Franke, Grimm ohne Glocken., pp. I45-I47.

I30 Grimm to Miegel, 31.01.1947, DLA - A: Grimm, Grimm to Miegel, 1933-1959.

I3I Guy Tourlamain, 'In Defence of the Volk: Hans Grimm's Lippoldsberger Dichtertage and völkisch Continuity in Germany before and after the Second World War', Oxford German Studies 39 (2010), No. 3, pp. 229-249.

I32 Annelies von Ribbentrop to Grimm, I6.II.I950, DLA - A: Grimm, Annelies von Ribbentrop to Grimm, 1950-I95I. 
noted that her son, Adolf, was reading Grimm's Im Lüderitzland. The children were required to explain Grimm's intentions in writing the story. Again she commented that the inclusion of his work in the curriculum was a 'very significant beacon of hope.' ${ }^{133}$

The Sudeten expellee, Hans Venatier, also reported to Grimm on Ioth January 1955 that his work as a teacher gave him an opportunity to shape young minds in Germany's favour:

As expected, your Hitler book [Warum - Woher - Aber Wohin?] has been hushed up once more in the press. But in the silence it is making the rounds, you can be sure of that. My Primaner are reading it and are astonished by what they find in it. And such things have further impact. I am often disheartened by the teaching profession, because it prevents me from writing. Then I find new strength in the knowledge that I can do a lot in this profession for the purification of minds. You would have had great pleasure in a lesson on the 'Gang durch den Sand'. Suddenly the young people were aware of the prophesying nature of a writer who had been presented to them elsewhere as a rigid, narrow-minded nationalist. As a result, one Primaner has requested an exam on Hans Grimm in the Abitur. In general, I see a change occurring in our young people. The paroxysm of the post-war years is diminishing, and self-confidence in their German being is beginning to grow again. ${ }^{134}$

Hans Venatier was twice required to justify his presence at Grimm's Lippoldsberger Dichtertage during hearings before committees of the government in Rhineland-Palatinate in the second half of the 1950 . In 1956 he offered to open the Dichtertag by reading his essay 'Warum ich trotzdem zum Dichtertag nach Lippoldsberg gehe.' This was written in response to the discussion at the first of these hearings, to which Venatier had been

I33 Annelies von Ribbentrop to Grimm, 26.II.1954, DLA - A: Grimm, Annelies von Ribbentrop an Hans Grimm, 1954-1957. Not everyone viewed the ongoing inclusion of Grimm's work on school curricula positively, as one commentator in a school student publication in Göttingen demonstrated: See H. Heick, 'Nun spinnen sie weiter ..., Impuls - Göttinger Schülerzeitschrift, Jahrgang I, Heft 7, Oktober / November 1949, Preis 25 Pfg, DLA - A: Grimm, Lippoldsberger Dichtertage: Konv - Zeitungsberichte Dichtertag 1949 u. 1950.

I34 Venatier to Grimm, I0.0I.1955 (mistakenly dated I954), DLA - A: Grimm: Venatier to Grimm. 
summoned as a result of a suspicion that he was propagating a neo-Nazi ideology in the classroom. ${ }^{135}$ Venatier presented the meetings as part of Grimm's effort to engage 'objectively' with the Nazi legacy and defended the honour of their shared nationalist position:

We call ourselves the Federal Republic of Germany, we have a commission 'Indivisible Germany', we hoist the national flag, but woe betide anyone [...] who identifies himself as a German, or even utters the word! Immediately, the cavillers, both abroad and at home, are on the spot, building that well-known progression of negative associations: national - nationalist - chauvinist - fascist - destroyer of the peace world conqueror - criminal. [...] Taught by the most horrendous catastrophe that has befallen us and the whole history of Christendom, we give the word national a better ring: nation, nationalist, national consciousness are the supporting walls, the bricks and mortar of Europe. ${ }^{136}$

Venatier saw the völkisch-nationalist position as the continuation of a longstanding, unblemished tradition in German nationalist thought. He shared Grimm's post-war belief in a European solution for the future based on the preservation of the individual racial characteristics of the continent's constituent nations. He viewed the crowds of visitors to Lippoldsberg each year in the 1950 s as an endorsement of the writers' political message, evidence that the German people were still hungry for the ideas they articulated. ${ }^{137}$

At the Lippoldsberger Dichtertag in 1959, his last, Grimm read Venatier's essay 'Ist das Neofaschismus?' in memory of its author, who had committed suicide the previous January. The essay had originally appeared in the journal Nation Europa in 1958 before being reprinted in several other right-wing publications shortly afterwards, attracting a ban in Austria. In response,

I35 Venatier to Grimm, 19.6.1956, DLA - A: Grimm, Venatier to Grimm, 1932-1958.

I36 Hans Venatier, 'Warum ich trotzdem zum Dichtertag nach Lippoldsberg gehe', DLA - A: Grimm, Venatier to Grimm, 1932-1958. The Kuratorium 'Unteilbares Deutschland' was founded in the FRG in 1954 , following the demonstrations of 17 th June in East Berlin. With members drawn from political, commercial and cultural life, its goal was to keep the idea of a united Germany alive. See Leo Kreuz, Das Kuratorium Unteilbares Deutschland: Aufbau, Programmatik, Wirkung (Opladen: Lesker \& Budrich, 1979).

Venatier to Grimm, 24.7.1955, DLA - A: Grimm, Venatier to Grimm, 1932-1958. 
Venatier himself had approached the Ministry for Culture and Education in Rhineland-Palatinate, appearing the second time before a committee in Mainz to explain his position. According to the numerous, dramatic farewell letters published in several right-wing organs, the meeting filled him with such despair that he decided to make a final sacrifice for Germany. While the underlying causes of his death remain unclear - it seems likely that ill health and psychological problems influenced his decision ${ }^{138}$ - he quickly became a martyr for right-wing publicists, and has remained such to the present. Certainly, Grimm presented him in this light in Lippoldsberg in 1959. ${ }^{139}$

After 1945, Grimm increasingly moved to the right-wing margins of Germany's political and cultural landscape. While he continued to emphasise the reservations he had long entertained regarding Hitler, the change in his view of the Nazi dictator evident by the early I950s mirrored his reaction to post-war German political conditions, which he viewed as detrimental to national development. Against this background, the Third Reich and Hitler, with all their problems, increasingly appeared in Grimm's commentaries in a more positive light than they had before 1945. Simultaneously, he moved closer to those who had been ardent supporters of the Nazi regime. His intensive communication with the wives of several leading Nazis, including Ilse Hess, whose husband was imprisoned in Spandau, and Annelies von Ribbentrop, the wife of the former Foreign Minister executed at Nuremburg, offers insights into his intellectual development after 1945, and his growing association with surviving Nazi circles in these years. Grimm sought to offer the two women support as they worked to resuscitate the reputations of their husbands, and in the case of Hess gain relief of his prison sentence.

I38 Among the publications that printed Venatier's farewell notes was a 'Sonderdruck' of the Nation Europa with the title 'Hans Venatier' (1959). The case was also commented on in a number of newspaper reports, including Rhein-Zeitung, Koblenz, Nr. 42, I8.2.59; Die Welt, I2.I.59; Frankfurter Allgemeine Zeitung, I2.I.59; Rhein. Merkur, 6.3.59. See DLA - Dokumentationsstelle / Zeitungsausschnittsammlung / Material aus dem Nachlaß Venatier, Hans.

I39 See for example, 'Verschwörung gegen die Zeit', Die Welt am Sonntag, 19.7.1959; 'Lesungen in Lippoldsberg' in Kasseler Post, I4.7.1959, DLA - A: Grimm, Dichtertage, Zeitungsberichte, 1959 . 
In doing so, he engaged in a project to 'correct' what he viewed as the mistakes of many commentators on the years before $1945 .{ }^{140}$

Annelies von Ribbentrop and Grimm also expressed shared outrage at the publication in 1950 of memoirs by Ernst von Weizsäcker, Staatssekretär under Joachim von Ribbentrop in the Auswärtigen Amt between 1938 and 1943, and the diplomat Erich Kordt, who had sought to warn the British government of the secret negotiations between Germany and the Soviet Union that led to the Nazi-Soviet Pact of August 1939. ${ }^{141}$ As he made clear to Ribbentrop's widow, Grimm viewed these works as evidence of a conspiracy in the civil service that had fundamentally undermined the regime and contributed to Germany's defeat, amounting to an outright betrayal of the German Fatherland. ${ }^{142}$ In opposition to these and other perceived traitors, including the conspirators involved in the bomb plot of 20 th July 1944, Grimm's völkisch honour increasingly overlapped with the residual defensiveness of former Nazis and their families.

Grimm also sought to aid both Annelies von Ribbentrop and Ilse Hess in their efforts to publish books and articles intended to revive their husbands' reputations. He was instrumental in advising Annelies von Ribbentrop throughout the process of editing the documents of her husband, which finally appeared as a book published by the Druffel-Verlag in 1954. ${ }^{143}$ The networks that developed after the war also crossed the Atlantic.

I40 On Grimm's involvement in campaigns for the release Rudolf Hess from prison, as well as his support for the wife of Wilhelm Frick, alongside Ilse Hess, see, for example, Grimm to Heuser, 24.8.1947, DLA - A: Grimm, Grimm to Heuser, 1935-1959; also Grimm to Kolbenheyer 4.9.1950, DLA - A: Grimm to Kolbenheyer, 1933-1959.

I4I Ernst von Weizsäcker, Erinnerungen (Munich: List Verlag, 1950); Erich Kordt, Nicht aus den Akten .... Die Wilhelmstrasse in Frieden und Krieg: Erlebnisse, Begegnungen und Eindrücke 1928-1945 (Stuttgart: Union, 1950).

I42 This is a recurring theme in Grimm's correspondence with Annelies von Ribbentrop throughout the i950s. See, for example, the letters sent by Grimm on ir.I0.1952, 23.I.1953, II.3.1953, 4.4.1953, DLA, A: Grimm, Grimm to Annelies von Ribbentrop, 1950-1959; Annelies von Ribbentrop to Grimm, I.3.195I, DLA, A: Grimm, Annelies von Ribbentrop to Grimm, 1950-1951.

I43 Joachim von Ribbentrop, Zwischen London und Moskau: Erinnerungen und letzte Aufzeichnungen. Aus dem Nachlass herausgegeben von Annelies von Ribbentrop (Leoni am Starnberger See, 1954). 
The magazine Der Weg, published in Buenos Aires, was particularly important for the far right and former Nazis in the early post-war years; it was through the former fighter pilot and Wehrmacht officer, Hans-Ulrich Rudel, that Annelies von Ribbentrop was able to publish in this organ in 1951. ${ }^{144}$ Ribbentrop's widow and Grimm both also worked closely with Arthur Ehrhardt, the editor of Nation Europa, another organ that provided them with access to a public in the early 1950 . ${ }^{145}$

Grimm also came into contact with members of the far right through his involvement with the Deutsche Reichspartei, for which he stood as a candidate in the Bundestag election in 1953, alongside Rudel, Adolf von Thadden and Werner Naumann. The latter had been Goebbels' Staatssekretär in the Propaganda Ministry. The DRP was concentrated in the northern states of the FRG in 1953. In the run-up to the election, it was clearly identified in the mainstream press as standing on the radical right. Its main hope lay with those who had previously voted for the Sozial Reichspartei (SRP), which had been banned the previous year. The DRP's campaign drew comment in the press, if not real enthusiasm among electors. According to Die Zeit on 27th August 1953, the Party had not made a very significant impact in Bremen during the election campaign, in spite of its ambition to win a mandate in the city-state at the expense of the SPD or DP. ${ }^{146}$ Even in Schleswig-Holstein, which enjoyed a reputation as a breeding ground for National Socialist sympathy in the early I950s, the newspaper reported that there appeared to be little enthusiasm for the Party. ${ }^{147}$ In the event, the DRP achieved only I.I per cent of the overall vote in the election and emerged without representation in the new Bundestag. It was noted that even in former SRP strongholds in Lower Saxony it was unable to match the latter's success. ${ }^{148}$ The Party nonetheless continued

I44 Annelies von Ribbentrop to Grimm, 15.7.1951, DLA - A: Grimm, Annelies von Ribbentrop to Grimm, 1950-1951.

I45 See, for example, Annelies von Ribbentrop to Hans Grimm, I.9.195I, DLA - A: Grimm, Annelies von Ribbentrop to Grimm, 1950-1951.

I46 'Aufmarsch der Parteien zur Wahl', Die Zeit, No. 35, 27.08.1953.

I 47 Ibid.

I48 'Trübsal in Hannover', Die Zeit, No. 37, 10.09.1953. 
to operate throughout the 1950 s, in spite of an abortive attempt in late 1953, supported by Chancellor Adenauer, to initiate proceedings to ban it as unconstitutional. ${ }^{149}$

Grimm's involvement with the DRP provided him with a public platform for his views. The Kasseler Post, for example, published a critique of his campaign, declaring longstanding sympathy for Grimm and appealing to him to rethink his support for the party. ${ }^{150}$ It also published Grimm's response, in which he emphasised that

I have never under any circumstances allowed myself to become the showpiece and box-office draw' of any party political propaganda. I stand behind the DRP as a fully free and independent man in my decisions. I placed myself behind this party as I saw that it offered perhaps the last chance to assist the Bundestag, currently the most visible German representation in the world, to achieve expression of a calm but secure Germanness in the public eye. Since 1945 I have increasingly seen the way all available means have been deployed in the attempt to prevent German statements and German things. ${ }^{151}$

He sought, he stated, to counter the constant assertion of German guilt for the National Socialist period, and the corresponding refusal to recognise the abuses done to Germany by opponents of National Socialism. With the Erzbischofschrift, he argued, he alone had sought to let fresh air into the discussion. According to Grimm, it had been the best-selling political book of 1950. The criticisms it met in the licensed press and commentaries on the radio were, in Grimm's view, nothing less than a continuation of the earlier betrayal of Germany. ${ }^{152}$

Grimm also commented on the case of Werner Naumann. In an obituary in 1982, Der Spiegel described him as a convinced National Socialist even after 1945, when he became a director of a German-Belgian import-export

I49 Grimm to Annelies von Ribbentrop, 13.10.1953, DLA - A: Grimm, Grimm to Annelies von Ribbentrop, 1950-1954.

I50 Herbert Schildener, 'An Hans Grimm. Und an Herrn Naumann auch', Kasseler Post, I3.8.1953.

I5 I Hans Grimm, 'Rechtfertigung der Wahlhilfe der DRP, I953', Kasseler Post, 28.08.1953.

152 Ibid. 
firm based in Düsseldorf. In January 1953 Naumann was arrested by the British occupation authorities for engaging in unconstitutional activities. While he was in custody, the DRP recruited him as a candidate for the I953 election campaign, causing an extraordinary 'denazification' process that left him, having previously remained uncategorised in the British zone, in group two and therefore unable to sit in parliament. ${ }^{153}$ His arrest and 'denazification' drew him out of political obscurity, as Konrad Adenauer noted in an election address in Munich in August $1953 .{ }^{154}$ In January 1953 , Grimm wrote to Annelies von Ribbentrop: 'The German position with regard to the so-called Naumann case has left me very upset. The things we have to put up with are completely unbelievable. I am convinced that the English foreign office has been urged on by men of Kordt's ilk, or those related to him.' ${ }^{35}$ In the Kasseler Post he pointed to the case as yet further evidence of the determination of both German and foreign authorities to silence those willing to speak out in Germany's favour. ${ }^{156}$

\section{Schleswig-Holstein}

Völkisch-nationalist writers after 1945 were motivated to work not only by a sense of obligation towards the Volk, but also by financial difficulties. The currency reform in 1948 left those living off savings and capital worse off than they had been in 1945. Prior to the currency reform, Miegel consistently assured Grimm that she was not struggling financially. On 28th March 1947 she wrote to him describing her living conditions in Apelern and contributing some reflections on the situation of the publishing industry

I53 'Werner Naumann' - obituary, Der Spiegel, No. 45, 8.11.1982, p. 272.

I54 'Aufmarsch der Parteien zur Wahl', Die Zeit, No. 34, 20.08.1953.

I55 Grimm to Annelies von Ribbentrop, 23.I.1953, DLA - A: Grimm, Grimm to Annelies von Ribbentrop, 1950-1954.

I56 Grimm, 'Rechtfertigung der Wahlhilfe der DRP, I953'. 
in relation to her work, most significantly the Diederichs Verlag, which had been partially responsible for her books before the war. Miegel continued to maintain close relations with the Diederichs family in these years, and they in turn sought to support her where possible by providing a pension drawn from the remaining assets of their firm in the West. She expected her life to resume its pre-war character, with a high demand for contributions to journals and magazines, as well as invitations to deliver readings and lectures. These were already reaching her in 1947 from admirers and colleagues, particularly from those representing Germans expelled from East Prussia and other Eastern European territories, as well as Heimat organisations in her new Lower Saxony home. ${ }^{157}$

On the eve of the currency reform, however, Miegel's optimism turned to concern. Having just moved to a small apartment in Bad Neundorf, on I8th June 1948 she described to Grimm the impact the change in currency would have on her existence and expressed concern that the new arrangements would end even the small consolations she still enjoyed following her expulsion from her homeland:

To receive letters from dear people and old friends, and to write to them all in turn - has been my greatest pleasure in the past I $3 / 4$ years. Now it will come to an end. For people without work, who must live from the pitiful remainder of their capital, post will be a luxury. Particularly when, as in our case, one has just gained a modest home of one's own. 'I took the risk' when a chance was offered to move here. Now I could live to regret it $[\ldots] .{ }^{158}$

Towards the end of 1949, Miegel sought to improve her financial situation by engaging in public readings and lecture tours. Nonetheless, while there appears to have been no shortage of an audience to hear her, her health prevented her from resuming these events on a large scale or for very long. ${ }^{159}$

Grimm, on the other hand, maintained a busy schedule of lectures and readings across Germany throughout the I950s. His appearances drew considerable audiences and attention in the press, both positive and negative.

I57 Miegel to Grimm, 28.03.1947, DLA - A: Grimm, Miegel to Grimm, 1933-1959.

I58 Miegel to Grimm, I8.06.1949, DLA - A: Grimm, Miegel to Grimm, 1933-1959.

I59 Miegel to Grimm, 8.02.1951, DLA - A: Grimm, Miegel to Grimm, 1933-1959. 
They throw light not only on his message in these years, but also on its reception in a West German public sphere that reflected the fluid nature of German national identity in the post-war years. On a number of occasions, Grimm was at the centre of controversy, not least following the cancellation of his speech 'Von der Wirklichkeit, die nach 1945 offenbar wurde' in Itzehoe on 26th October 1955. This followed a ban issued by the government of Schleswig-Holstein, ostensibly as a result of the involvement in the organisation of the event of the Vereinigung ehemaliger Internierter und Entnazifizierungsgeschädigte. As a number of newspapers were swift to note, the timing of the ban coincided with a conference of the Big Four in Geneva, at which, among other topics, German reunification was on the agenda. It came at a time in which Germany was particularly concerned to demonstrate that it had overcome National Socialism. Some commentators suggested that this influenced the decision to silence Grimm. ${ }^{160}$

The public response to the episode reflected the tensions that existed in German society in the mid-1950s. Reporting on the anticipation of both Grimm's supporters and his opponents on the eve of the planned lecture in the Itzehoer Stadttheater, the Norddeutsche Rundschau asserted that Grimm's literary significance was unquestionable. The article echoed Grimm's own version of his political biography in explaining that he had been increasingly marginalised following the Machtergreifung in 1933 , but that since 1945 his commitment to Germany had left him no peace: while the Erzbischofschrift and Warum - Woher - Aber Wohin? had been condemned in some quarters, both works had provided comfort in others. Even Grimm's opponents, the paper suggested, recognised that his work had always been inspired by his deep-seated concern for Germany. Thus, the newspaper suggested, his listeners were less concerned with literary issues and more interested in the views of an 'unerbittlicher, oft unbequemer Wahrheitssucher. ${ }^{161}$

By contrast, the Schleswig-Holsteinische Landeszeitung suggested that the majority of those who had turned up to hear Grimm in Itzehoe,

I60 'Im Scheinwerfer der Öffentlichkeit - Volk ohne Traum', Rundschau zum Sonntag, 5.II.1955.

16I Norddeutsche Rundschau, I5. October 1955, 'Unsere lokale Seite'. 
only to be turned away disappointed by the police, were members of the older generation. Their interest in his post-war political message, it was claimed, was limited; they were motivated by a desire to see the author of Volk obne Raum in person. ${ }^{162}$ Similarly, the Rundschau zum Sonntag on sth November 1955 estimated that of the five-hundred listeners who had previously provided an audience for Grimm in Kiel, four-hundred were primarily interested in Grimm's literary prominence. ${ }^{163}$ All the same, given the political nature of Grimm's most famous novel, and his prominence as a spokesman for the national right, enthusiasm for his work is difficult to separate from the völkisch worldview of previous decades. While most members of his audience probably did not identify themselves as völkisch, let alone residual Nazis, their enthusiasm to hear what Grimm had to say indicates the existence of a nostalgia for the familiar literary themes of previous decades. This perhaps also reflects unwillingness among some Germans to recognise the role of völkisch-nationalist thought in creating a climate in which the Nazis were able to gain power. While the SchleswigHolstein ban was officially directed at the event in Itzehoe as a meeting of the Vereinigung ehemaliger Internierter und Entnazifizierungsgeschädigte, a number of further groups were also involved in the organisation of Grimm's lecture. These included the Landesverband der Vertriebenen Deutschen; the Soldatenverband and the Heimkehrerverband. ${ }^{164}$ The nature of these organisations provides further insights into the questions that concerned at least some of Grimm's potential audience: 'denazification', the expulsion of Germans from territories in Eastern Europe, the challenges faced by returning prisoners of war and, more generally, former soldiers.

In general, Grimm's racial message coupled with his assessment of Germany's treatment on the international stage over decades was designed to appeal to a shared sense of German victimhood among the members

I62 'Hans Grimm erhebt Einspruch', Schleswig-Holsteinische Landeszeitung, Nr. 252, 28.10.1955, p. I.

I63 'Im Scheinwerfer der Öffentlichkeit - Volk ohne Traum', Rundschau zum Sonntag, 5.II.1955.

164 'Hans Grimm erhebt Einspruch'. 
of these organisations. The Schleswig-Holsteinische Landeszeitung and its associated newspapers addressed this question in a second article on the ban, this time an opinion piece, on 28th October. Its comments reflected the general dissatisfaction caused by the 'denazification' process, arguing that there was nothing wrong with the victims of the modern 'witch hunt' after 1945 coming together to provide each other with mutual support. ${ }^{165}$ Nonetheless, it was also noted that their activities had previously gone beyond reasonable mutual assistance in overcoming the difficulties they had encountered as a result of 'denazification', leading to a series of organised events that had included discussions of 'Siedlungsraum in the East', a theme Grimm also addressed in the banned speech. Applauding the decision to stop these events, the commentator condemned those like Grimm who still spoke of 'German Siedlungsraum in the East' or the 'healthy ideas of Hitler', pointing out that encouraging German youth to adopt the spirit of Hitler directly contradicted the ideals of those honourable men seeking to establish the new German state. ${ }^{166}$

Following the cancellation of the lecture on 26th October in Itzehoe, two further lectures were also prohibited by the state government in Schleswig-Holstein, in Eckernförde and Schleswig. Grimm voluntarily cancelled the final station on his tour in Flensburg and returned to Lippoldsberg. In all, as Grimm and his defenders pointed out, he had already delivered the speech in twenty-two cities, including Bonn, before his arrival in Itzehoe. It had, therefore, already reached a wide public. Grimm presented his case in the Reichsruf in November 1955, pointing out that in addition to attracting significant audiences to these previous events, an audio recording of the speech had, without his knowledge at the time, been made in Mannheim. Moreover, a version also appeared in a collection of Grimm's essays published by the Göttinger Verlagsanstalt the same year. ${ }^{167}$ This firm was owned by Karl Waldemar Schütz, also editor of the

I65 'Unser Kommentar - Nazis', Schleswig-Holsteinische Landeszeitung (and associated newspapers), 28.10.1955, p. 2.

I66 Ibid.

I67 Grimm, 'Von der Wirklichkeit, wie sie nach 1945 offenbar zu werden beginnt', Erkenntnisse und Bekenntnisse, pp. 175-203. 
Reichsruf and proprietor of the Plesse-Verlag that had published Grimm's Erzbischofschrift. Schütz was prominent in right-wing politics in Lower Saxony, gaining a seat for the DRP in the Landtag in 1955. He was also instrumental in ensuring Grimm's speech appeared in print and providing Grimm with an opportunity to present his case in response to the actions of the Schleswig-Holstein authorities.

Grimm acknowledged in his article in the Reichsruf that while Article 5 of the Basic Law ensured freedom of expression in the FRG, the Versammlungsgesetz of 24.7.1953 included a provision prohibiting addresses that would incite crime. Nonetheless, as far as Grimm was concerned, a ban was unjustified on these grounds, given the uneventful nature of the previous occasions on which the speech had been delivered. He viewed the involvement of the Deutsche Gewerkschaftsbund (DGB), alongside the SPD, in silencing him in Itzehoe as a sign of the influence of the trade unions over the politics of Schleswig-Holstein. He recounted that only minutes before he had delivered the same speech in Mölln, the police had asked him not to mention Hitler as it angered the trade unions. Grimm stated, however, that he felt obliged as an independent German to present the unadulterated truth regarding the German Volk and its fate for the sake of future generations. This, he said, was more important than the political games of functionaries and the gossip propagated by newspaper reporters. ${ }^{168}$ His appeal to the importance of preserving völkisch integrity for future generations was implicitly racial, corresponding with his conviction that the threats to the German Volk were not simply political in nature, but aimed at undermining its very being.

Appeals were made against the ban in the months that followed, first by the Schleswig-Holstein Landesverband of the Vereinigung ehemaliger Internierter und Entnazifizierungs-Geschädigte. This was withdrawn after the state government demanded power of attorney over the organisation on the grounds that the organisers of the banned events had not been the Landesverband, but the individual Kreisverbände. Grimm also appealed the decision, which led to the case dragging on for a further two years 
before his position was finally rejected in November 1957. The outcome of Grimm's case was reported in newspapers across Germany. ${ }^{169}$

A number of versions of Grimm's banned speech have survived, including corrected drafts among his papers and a published essay in the collection published by the Göttinger Verlagsanstalt in 1955, Erkenntnisse und Bekenntnisse. ${ }^{170}$ It is likely the latter is fairly close to the version he took with him to Schleswig-Holstein, particularly given the fact that Grimm preferred to read a prepared text on such occasions rather than speak freely. ${ }^{171} \mathrm{He}$ began with a discussion of the congress on demography held by the United Nations in Rome in September 1954. He used this as a vehicle to discuss the issue of overpopulation that increasingly preoccupied his post-war work. He suggested that the matter concerned the survival of the human race, and its most gifted members. Drawing on the theories of Thomas Malthus, he presented his position as one established long before and therefore independently of National Socialism. This strategy claimed legitimacy for his position not only as a result of the longevity of Malthus' influence, but also by emphasising that his ideas came from Britain. Implicitly, Grimm suggested that the western Allies were hypocritical in judging Germany harshly for what had taken place under the Nazis given that similar ideas had been evident in their own countries for at least a century. ${ }^{172}$

Grimm courted criticism by presenting a eugenicist position that argued the human race was degenerating biologically through the failure to rid it of hereditary diseases. Citing unattributed infant mortality rates and population forecasts for India, he argued that while the problems of

I69 See for example, Die Stuttgarter Zeitung, 25.11.57, DLA - A: Grimm, Verbot in Schleswig-Holstein.

I70 Grimm, 'Von der Wirklichkeit, wie sie nach 1945 offenbar zu werden beginnt', file containing draft manuscripts, DLA - A: Grimm, Manuskripte. See also Grimm, 'Von der Wirklichkeit, wie sie nach 1945 offenbar zu werden beginnt', Erkenntnisse und Bekenntnisse, pp. 175-203.

I7I 'Im Scheinwerfer der Öffentlichkeit - Volk ohne Traum', Rundschau zum Sonntag, 5.11.1955.

I72 Grimm, 'Von der Wirklichkeit', p. I70. Quotations from Grimm's speech are taken from the published version unless otherwise stated. 
overpopulation were going to affect the Asian world most significantly, the Europeans and Americans had failed to take into account the impact these increases would have on their own lives. Grimm also used the question of over-population to consider the drawbacks of capitalism: he pointed out that while American thinking assumed that the growing numbers of people would be provided for by expanding economic markets for ever larger quantities of basic goods, most notably foodstuffs, the population was growing most strongly in those places least able to pay for the goods needed to feed their people. At the same time, Grimm proposed that increases in the American population would strain the capacity of the USA to produce enough to feed its own people, reducing the surplus available for export. Finally, in addition, the creativity needed for the technological and scientific progress required to produce new sources of food and raw materials, found according to his racial worldview among Europeans and Americans, was threatened with degeneration as the racial health of the populations in these regions declined.

Grimm also linked the population question to the threat of Bolshevism. He returned to his old concerns regarding people and space, race and the role of Heimat. For Grimm, through the forced relocation of populations, the Soviet rulers had deliberately severed the connection of the peoples they dominated from their native lands. This had allowed them to consolidate their power, weakening the ability and determination of the people to protest against the conditions in which they were forced to exist. This was a cautionary tale for the Germans: a people severed from their Heimat will be fundamentally weakened and susceptible to negative outside influences. Germany was particularly vulnerable, divided between east and west and with a large number of displaced people as a result of the expulsions from Eastern Europe and the soldiers still returning from the Russian front. The Bolsheviks were foreign to many of the peoples they governed, their power was based on terror and the severance of people from their native lands; the Nazis, on the other hand, had emerged from the Volk and had emphasised the importance of Heimat. ${ }^{173}$ 
Grimm went on to discuss Germany's recent history. With Germany's rise as an economic power in the early years of the twentieth century, he argued that the German population had become increasingly used to a standard of living that was untenable within Germany's borders given the increase in the size of the population that accompanied this development. Thus, Germany had been weakened by her dependence on foreign powers to deliver the required levels of food and raw material imports. He provided an economic analysis of the causes of the First World War: Germany's enemies had sought to prevent her further economic development and limit the competition she presented to their own interests. The loss of the war and the shortages it caused had allowed Bolshevism to emerge within Germany's borders. ${ }^{174} \mathrm{His}$ reminder of Germany's difficulties after the First World War is likely to have aroused memories of similar or worse suffering as a result of the Second in the minds of his audience of aggrieved former Nazis and those expelled from their homes by the Red Army. In suggesting that it was under these conditions that Bolshevism first took on a concrete ideological shape, he connected his vision of the threat from the East to the wellbeing of the Germans themselves.

The most controversial aspect of his lecture was, however, the attitude he expressed towards Hitler. The way in which Grimm's view of the former dictator developed after 1945 is striking. From his non-committal and at times even critical attitude towards the Party in the 1930s, and apparent distaste regarding Hitler as a man, he came to espouse a view of the former dictator as an early Austrian-German idealist who had displayed impressive foresight regarding Germany's problems, forming the basis for his political activities in the I920s. These sought, according to Grimm, to counter the threat of Bolshevism coming from the East. In the light of the post-Second World War situation in Eastern Europe, Grimm suggested that Hitler had been ahead of his time in acting against the threat that continued to loom in the East. ${ }^{175}$

Grimm's comments reflected his position in post-war Germany, not his position during the Third Reich. He responded as much to the new

174 Ibid., pp. 179-180.

175 Ibid., p. I86. 
conditions in Germany that had seen respect for his ideological position diminish over the years, as well as a new world order characterised by the Cold War and the overarching rivalry between the two global superpowers. It should also be noted that his contacts with former Nazis, and in particular the wives of Rudolf Hess and Joachim von Ribbentrop in I950s also had a significant influence over his retrospective view of the Nazi movement. Moreover, emphasising his own change of perspective provided a strategy for distancing himself from connection with the problematic elements of the Third Reich; he presented himself as someone naturally critical who had only come round to recognise Hitler's strengths when it was almost too late. He stated that he became aware of the historical importance of Hitler only when the dead man had become the scapegoat for the evil actions of others, while at the same time politics at all levels were blind to the situation that Hitler had once sought to counter. He also suggested that since 1945 it was possible to recognise the situation in which Hitler had actually found himself, lonely and isolated in his struggle while others sought to undermine him. ${ }^{176}$

Grimm sought to turn Hitler into a prophet for the sake of future generations. Germany still faced unsolved questions that had existed long before the emergence of Hitler and National Socialism. And after 1945 they had become clearer and more threatening than even Hitler's 'traumhafte Sicht' had recognised. He presented Germany's fight during the Second World War as a struggle against Bolshevism on behalf of Western Europe. In Warum - Woher - Aber Wohin? he quoted an unnamed German-Dutch woman, who allegedly wrote in 1952 :

Now I see everything with a focus on the Soviet Union; and without a doubt, it is thanks to Hitler that Germany is still not a Soviet republic. It is so often said that Hitler should not have started [the war] against the Russians; but then the logical consequence would have been an alliance with the Soviets against the West, and I maintain that that would have been suicide for us all. ${ }^{177}$

176 Ibid., pp. 188-189.

177 Grimm, Warum - Woher - Aber Wobin, p. 382. 
In his banned speech, Grimm declared that Hitler's attempt to bring about a solution had led to huge suffering for many respectable and well-intentioned people. Nonetheless, Hitler had already recognised the dangers facing the human race thirty-five years earlier, and sought to counter the threat through the establishment of a North-Germanic Reich:

In the Reich the word Nationalism was not emphasised, but instead the words herditary health, nurture of family, achievement, racial preservation. And everything possible was to be done to maintain these values. The Reich was not intended to disrupt England in its global task in the face of increasing overpopulation, or America, or the peoples of the Mediterranean. The Reich was to be as Dutch as it was German, and as Danish, as Scandinavian and French, and the positions of highest leadership were to go to the best, those who had achieved the most. It was deliberately intended as a dam against the human failure in the advanced life of the Earth, which has meanwhile become so visible. ${ }^{178}$

Grimm believed, moreover, that Germany remained the bulwark against Bolshevism in Europe after 1945, just as Japan, and more particularly Formosa and South Korea filled this role in Asia. The threat to the future would not come, he argued, from nuclear war or the struggle for nuclear energy. The real danger to the world was unlimited population growth and the resulting competition for food and materials necessary for life. In this struggle the masses would overrun countries and states, destroying their structures and orders without considering the resulting losses to human civilisation. Grimm therefore posed the question: 'What life should be protected as healthy and of service to the world and what life should be deemed damaging from its very roots and eliminated?' He viewed this as a controversial question of conscience, and claimed that it, urgently demanded an answer. ${ }^{179}$

Grimm expressed views in Schleswig-Holstein that mirrored his lengthier post-war writing in which he sought to place Germany's post1945 history in a global context. Echoing the message of Warum - WoherAber Wobin?, which had appeared the previous year, his speech was also

178 Grimm, 'Von der Wirklichkeit', p. 195.

I79 Ibid., pp. 190-I9I. 
an appeal for a reassessment of the prevailing negative interpretation of the Nazi past. He concluded, therefore, by emphasising that the Germans were forced to live divided without a formal peace settlement and listing Germany's losses: the Oder-Neisse region was passed to Poland as compensation to the Poles for relinquishing their own eastern territories to the Soviet Union. In other 'stolen' German territories, like East Prussia, Pomerania and the Sudetenland, farmland lay uncultivated. These regions had previously guaranteed Germany's corn supplies. They had ensured an agricultural surplus which the western zone alone would never be in a position to match. Without these areas, a reunified German Reich, following an eventual peace treaty, would be forced to export more and more cheap goods in order to cover the expense of the most basic needs of the German Volk. And cheap German exports would increasingly come at the expense of Britain. Should German exports be cut off by force, Bolshevism would take hold, not as the result of war but of the deprivation and anger of a helpless German people. England, on the other hand, would need to prevent German exports. In only a matter of decades she too would be facing similar problems on an overpopulated small island. Grimm asked his listeners what was to be achieved through the condemnation of Hitler. He asked what had been achieved by punishing National Socialists, of whom, he added, ten percent were still good Germans and once again rejected the 'criminalisation' of the German people around the world and in Germany itself. ${ }^{180}$

As the solution to the problems outlined in his Schleswig-Holstein speech Grimm proposed the creation of a 'nation of Europe'. This became the goal of his post-war work, in which he engaged with an initiative that had supporters beyond Germany's borders, bringing him into contact not only with surviving far-right networks in Germany, but also those operating internationally. Grimm was also closely involved with the magazine Nation Europa, which brought him into contact with the British Fascist leader, Sir Oswald Mosley, his wife Diana, and the Union Movement established by the British fascist leader after 1945 .

I80 Ibid., pp. 198-203. 
In spite of a lack of surviving correspondence between Grimm and the Mosleys in Grimm's papers, Oswald Mosley's papers do contain one letter from Grimm, begun on 24th January 1950 and completed on 29th January 1950. It confirms receipt of a letter from Mosley of I 6 th January, apparently written in response to an earlier communication from Grimm on the roth of that month. Grimm was involved in advising Mosley on the most suitable format for a new German edition of Mosley's book The Alternative. On this issue Grimm had also apparently consulted Ellen Soeding, a minor novelist of the Nazi era, who collaborated with Grimm on the preparation of a number of texts, among them several published by the Klosterhaus Verlag. ${ }^{181}$ Grimm's letter to Mosley provides a number of insights into right-wing networks, most particularly connections between Germans and like-minded figures on the far right elsewhere in Europe. Both Grimm and Mosley took an interest in the Nation Europa in its early years. Grimm provided articles and also editorial advice to its editor Arthur Ehrhardt. ${ }^{182}$

The Nation Europa remains one of the leading organs of the German right. It was established in $195 \mathrm{I}$ and, in common with counterparts in other countries, developed a style of pan-European activity that emerged as groups in several countries looked to the European arena for the room to manoeuvre denied them at the national level. Mosley was linked to the initiative from the start. ${ }^{183}$ Müller notes that Mosley's involvement in the journal gained it added notoriety, as well as support in some circles. ${ }^{184}$

I8I See Grimm's correspondence with Ellen Soeding, DLA - A: Grimm, Grimm to Ellen Soeding, 1948-1959; DLA - A: Grimm, Ellen Soeding to Grimm, 1948-1959. Grimm also discusses their work together in letters to Annelies von Ribbentrip, e.g. I0.04.1951, 28.06.1951, I2.07.1951, 17.10.1951, 30.12.1951, DLA - A: Grimm, Grimm to Annelies von Ribbentrop, 1950-1954.

I82 See for example Grimm to Ehrhardt, 28.8.195I, DLA - A: Grimm, Grimm to Nation Europa, I95I-I957.

I83 Grimm to Kolbenheyer, 21.10.1950, DLA - A: Grimm, Grimm to Kolbenheyer, 1933-1959.

I84 Quoted in Müller, West Germans against the West, p. 48. 
The efforts of the Nation Europa to intellectualise right-wing rhetoric also had roots in the work of a number of groups and individuals after the Second World War. The initial impetus for pan-European activity came from Italy, where the neo-fascist movement, Movimento Sociale Italiano (MSI) established contact with former Nazis in West Germany, as well as fascist groups across Europe and even in South America and the Middle East. In March 1950 it was instrumental in organising a first meeting of interested parties in Rome. Alongside representatives of the MSI, the Spanish Falange, and the German Bruderschaft sent representatives. In addition, Mosley was among those present. At a second, larger conference later the same year delegates came from France, England, Spain, Italy, Denmark, Norway and Germany, as well as Belgium, Switzerland, Portugal, Albania and Romania. ${ }^{185}$

In Germany such pan-European activities provided intellectuals on the right with a context in which to distance themselves from the Nazi regime, whilst maintaining the racist and nationalist views that had underpinned it. To this end, the journal provided writers and commentators like Grimm with a forum for political commentary. In a letter to the Nation Europa on 2nd December 1954, which thanked the editors for their positive review of Warum - Woher - Aber Wohin?, Grimm discussed his view of Hitler and Germany's future. He demanded greater differentiation when judging the Third Reich:

[...] I believe this correction is necessary. It should in no way indicate that I possessed a clear view of the political figure of Hitler from the beginning. [...] But what is important is that we finally gain a clear view [...] of the reality facing humanity and the difficult task confronting future generations in Christendom, to which our children and grandchildren belong as a result of their geographical location. [...] The new conditions of life and the new laws governing human behaviour will look to the causes rather than speak of guilt. They must be found by the coming generations in the Christian world. If that does not happen, we Europeans will be lost. ${ }^{186}$

I85 Quoted in Kurt P. Tauber, Beyond Eagle and Swastika: German Nationalism since 1945 (Middletown: Wesleyan University Press, 1967), pp. 208-209.

I86 Grimm to Nation Europa, 2.12.1954, DLA: Grimm to Nation Europa, I95I-1957. 
Rewriting history, Grimm argued that Hitler's early adoption of the common European cause had been represented in areas of the Nazi institutional landscape, not least in the international SS-units. In an article entitled 'Reich Europa', Grimm wrote:

The call for a 'Nation Europe' in conjunction with the very conscious maintenance of the different Volkheiten was not so very many years ago already the creed of life and death, without emerging as such in public consciousness. It was [...] the secret light that drew French, Flemish, Dutch, Walloon, Danish, Scandinavian, Finnish, Swiss, Irish, Lithuanian, Latvian, Ukrainian, Estonian and other 'foreign' men into certain SS-formations, in spite of their other concerns and their deep love for their homelands. None of these men were looking for service of a German 'state nationalism' or some form of foreign rule, or party rule, or a fight with their own true and beloved people. Instead they were all striving for the 'Reich Europa', which was beginning to make itself apparent, and they were all striving to defend Europe from the threat from Communism and Marxism and overpopulation and, not least, biological neglect and confusing Americanism [...]. These men wanted to win 'Europe' and desired at the same time to restore the original creative powers and innate importance of their own Volkheiten, free of all political rhetoric and babble. ${ }^{187}$

Hans Grimm and his colleagues rejected the official line on the Second World War in post-war Germany, which emphasised German aggression. This official line was encouraged by the occupying powers, and generally accepted by Adenauer's government after 1949, as well as most of those leading intellectuals who had been exiled from the Third Reich. Nonetheless, the idea of German guilt was unpopular among the population, and the nationalist rejection of collective responsibility, and indeed assertion that the Germans had acted in the best interests of all of Europe in going to war against the Soviet Union, fell on fertile ground. This was also nourished by a sense of grievance at the way in which German suffering had gone unrecognised. Anti-Bolshevism among West German nationalists in the 1950 s fitted into a wider, at times even contradictory intellectual attitude that, to a degree at least, also characterised mainstream German conservatism. A general acceptance of the importance of defending freedom and the rule

I87 Grimm, 'Reich Europa' in Grimm, Erkenntnisse und Bekenntnisse, pp. 65-76; here pp. 68-69. 
of law from the totalitarian threat posed by the U.S.S.R. underpinned the efforts of the Federal Republic to fit into the new global situation brought about by the Cold War. ${ }^{188}$ This combined with a suspicion of American culture among many conservatives, who shared ideas common on the radical right in their refusal to accept the power relations of the Cold War. In this context, the idea of a united Europe as a third global force was a strategy that allowed its adherents to recognise the dangers from the East whilst asserting the ongoing importance of European culture, to which Germany had been a significant contributor, and Europe as an independent political actor in the face of perceived American domination.

\section{Conclusion}

Hans Grimm was increasingly associated with the extreme right and by the time he died in 1959 he found himself on the margins of the German political spectrum in a way that he had not done previously. He was far from alone among his völkisch colleagues, although the level of his continued activity remained higher than that of many others of his generation. This makes him of particular interest here. The process of marginalisation experienced by Grimm and his colleagues did not occur overnight; indeed positive newspaper reports suggest that völkisch writers retained the endorsement of sizable sectors of the population after 1945. Striking chords with the concerns of many Germans after the War, their efforts to distance themselves from National Socialism were juxtaposed with attempts to relativise the history of the Third Reich. Experiences of suffering rather than guilt were common in the population at large. The völkisch-nationalist message of racial and national rebirth presented the post-war population,

I88 Axel Schildt, 'Ende der Ideologien? Politisch-ideologische Strömungen in den soer Jahren', in Schildt and Sywottek (eds), Modernisierung im Wiederaufbau, pp. 627-635; here: p. 630. 
socialised under the Nazis, with a familiar cultural option. It emphasised the common national heritage of the dislocated population, and recognised the hardships the German people had experienced as a result of the War. Reacting to the official anti-Nazi rhetoric of the occupying powers, Grimm, Kolbenheyer and their colleagues consciously sought to provide a framework for a new cultural identity based on völkisch-nationalism.

At the same time they emphasised their anti-Soviet position, a sentiment shared by an overriding majority of West Germans, and nurtured an ideal of Heimat based on an implicitly racial definition of the German nation. Anti-American sentiments were also prevalent across the political and social spectrum, but, as Müller demonstrates, they were particularly evident on the right wing. ${ }^{189}$ The Allied occupiers were held responsible for Germany's situation and the suffering of her population during and after the War. The 'denazification' and 're-education' programmes, as well as alleged attempts to impose foreign, particularly American, culture on the Germans, were considered yet further continuation of a long tradition of British and American oppression of Germany. This resentment had already found expression in earlier völkisch-nationalist literature, particularly during the interwar years in response to the Versailles Treaty. It was now also linked to widespread grievances in Germany as a result of the post-war situation.

From a völkisch perspective there was little promise of a resolution for Germany's fundamental problems on the international stage. These were felt to go back several generations, representing the long-term, underlying causes of Germany's actions during the Second World War. By presenting modern German history as one of victimhood at the hands of the other European powers, these writers tuned to and shared popular resentments in the decade immediately following the Second World War, allowing them to carve out space in the West German public sphere that ensured a readership for their publications and audiences at public lectures and events. 



\section{Concluding Remarks}

On the death of Erwin Guido Kolbenheyer in 1962, Curt Hohoff wrote in the Süddeutsche Zeitung: 'Kolbenheyer's story can be explained through the combination of his origins, education, studies and the literary possibilities of his time. He was a passionately engaged writer and, as a result, he erred in numerous ways; and because he was also a passionate person, he became unmercifully enmeshed in his mistakes. ${ }^{11}$ Hohoff, who in his youth in the I930s had been active in the circles that developed around the LMV, was by this stage far from complimentary about Kolbenheyer's life and work. He was forced to wrestle with the dilemma that writers like Kolbenheyer and Grimm presented after 1945. Their ideology and literary work had responded to the ethical and political challenges facing their generation, and, as Hohoff notes about Kolbenheyer, in their responses they had drawn on the contexts from which they had come. For Hohoff, the combination of Kolbenheyer's passion and the circumstances of his time had combined to draw him towards the mistaken conclusions presented in his philosophical works. These conclusions had also found a more primitive echo in the Nazi ideology.

Kolbenheyer was the last survivor of the Munich Consensus. Grimm had died three years before in 1959, Schäfer and Strauß in 1952 and 1960 respectively. Like such contemporaries, Kolbenheyer was not a product of National Socialism. Well established before 1933 as the creator of serious literature, he had gained attention that went far beyond the right-wing margins with which he was increasingly identified after 1945. The presence of his works on the respectable bookshelves of the German Bildungsbürgertum over the previous half-century presented the writers of his many obituaries

I Curt Hohoff, 'Er hütete das "nationale Plasma” - Zum Tode von Erwin Guido Kolbenheyer', Süddeutsche Zeitung, 14.4.1962, DLA: Erwin Guido Kolbenheyer, 3: Würdigungen. 
with a considerable challenge in explaining why such a writer still needed to be taken seriously. ${ }^{2}$

This challenge remains for historians seeking to understand the writers discussed in this book. Such writers had lived through four German regimes, providing ideological continuity on the far right from the Kaiserreich of the late nineteenth century down to the FRG. In doing so, they responded to an ongoing sense of threat posed by modern life to German life and culture. The intangible general sense of this threat was projected onto the specific political and social upheavals they experienced. Their responses drew on the völkisch tradition that had informed the consciousness of the middle classes in particular during their youth. Their ideological position provided them with a point of continuity in the face of ongoing change throughout their lives. Their stubborn adherence to racial nationalism was not, however, born of reaction but of revolutionary idealism, which remained unsatisfied to the end of their lives. The failure of the Nazi regime to fulfill their ambitions for a völkisch state, in spite of its initial promise, left them after 1945 struggling to explain their roles in the creation of an ideological climate that had allowed National Socialism to gain a hold in Germany. Rather than accepting the roles they had played, they clung to völkisch-nationalist principles as the as yet unrealised answer to the challenges which Germany continued to face in the modern world.

The relationship between the writers in question and the National Socialist regime was, on the whole, one of critical support by the writers. But it also changed as the years passed. Seeking support in the late I920s and early 1930s, the Nazis courted prominent völkisch authors, encouraging them in what became after 1933 a misguided assumption that they would have a defining role in the formation of the political culture of the Nazi state. The Nazi rhetoric of revolution also provided a rationale that allowed these writers to continue to believe in the possibility of ongoing change after the Nazi seizure of power. 1933 was thus not viewed by them as the end, but only as the start of the völkisch revolution. Nonetheless, by

2 A large selection of obituaries can be found in DLA: Erwin Guido Kolbenheyer, 3: Würdigungen. 
the end of the decade, most were disillusioned with the form the regime had taken, and more particularly with their own place in it. This did little, however, to undermine their fundamental racial nationalist convictions and their adherence to the idea of a völkisch social order.

It is important to recognise the depth of conviction from which writers like Hans Grimm and Erwin Guido Kolbenheyer were acting. While often caught up in self-regard and a desire for self-aggrandisement, they were not cynical actors on Germany's literary stage, but responded to the events that influenced the course of German history during their lifetimes, out of a deep conviction that Germany had taken the wrong road following unification in $187 \mathrm{I}$. Seen from a contemporary perspective, and through the lens of the Holocaust, the solutions they proposed seem misguided at best, inhuman at worst. Such a judgement does not, however, mean that they are unworthy of further consideration. To recognise that the men and women studied in this book believed that they were working for a better society is not to endorse their worldview, but it does offer an avenue for understanding how they and many like them arrived at a position in which the Nazi regime appeared a positive step in the right direction. Their subsequent disappointment and disillusionment with the regime also provides insights into their failure to identify their own position with the crimes committed in the name of the German people during the Second World War. These men and women were in many ways typical representatives of a generation that had a fundamental impact on the course of the twentieth century. Highlighting their point of view offers a perspective on an intellectual position shared by many Germans, whose right-wing position, combined in their everyday lives with a sense of continuity in their role in the overall social scheme in Germany, allowed them to retain a perception of moral independence that distanced them from responsibility for the German catastrophe.

The völkisch vision of a society based on estates in which the role of true German writers as representatives of the German spirit and the conscience of the nation would be truly recognised provided the writers examined in this book with their moral framework. Their duty to their Volk was the overriding motivation for their actions throughout their lives. The sense of obligation they expressed also helps explain their literary endeavours; 
they believed in themselves as the guardians of German literature against the outside influences perceived to be invading German culture. They were helped to this conclusion by the myth of a German past that looked back to the idea of medieval guilds as a model on which society should be structured, and viewed the producers of literature with particular reverence. Germany in the modern world should once again be the land of Dichter and Denker. By restoring the centrality of the written word in German culture, they hoped to counter the internationalising tendencies they identified in the unprincipled and deconstructive avant-garde writing of the early twentieth century. In their eyes, modernist culture re-emerged as a dangerous influence on the character of the Federal Republic after the Second World War.

On the other hand, as time passed they increasingly understood their own efforts in a broader international context. This became particularly important after the Second World War, when they promoted völkisch principles as the basis for the reconstruction not just of Germany, but Europe as a whole. The future of the 'white race' depended, they argued, on the cooperation of the individual European Völker against the Bolshevik threat from the East and American melting-pot culture from the West. This also became fundamental to their defense of Hitler's foreign policy, which became, in völkisch rhetoric, a far-sighted attempt to preempt the problems Europeans were facing in the 1950s. In many ways, in their efforts to defend the Nazi regime after the War they came closer to wholehearted support of the regime than they had offered when the Nazis were actually in power. This was also partly the result of the process of marginalisation they experienced as the 1950s progressed. As they found themselves pushed towards the far-right margins over the course of the decade, they also found solidarity among the circles of former Nazi functionaries. In this environment, völkisch grievances were fuelled.

As the representatives of an ideology that, in theory at least, rejected reason in favour of lived experience and feeling, they were full of contradictions. This adds to the difficulties which subsequent generations of scholars and commentators have had in pinning völkisch-nationalist writers down. While their contacts with former Nazi officials increased after 1945, in the post-war years they also emphasised their earlier struggle against the 
attempts by the Nazi rulers between 1933 and 1945 to subjugate all cultural production to the service of politics and propaganda. Their resistance to the latter should not, however, be viewed as a rejection of the Nazis' racial ideology, but as the defence of German literature against the instrumentalising tendencies of the regime. Here they remained consistent throughout their lives, and against the backdrop of the rivalries that characterised the institutions of the Nazi government, the maintenance of independent völkisch networks through the Third Reich was in many ways their greatest achievement. Their correspondence and private contacts were vital, but broader frameworks also continued to function, in spite of the Nazis' attempts to undermine them. The Literature Academy provided a context that brought the Munich Consensus together, even while it was increasingly redundant in the practical government of the literary sphere. Beyond formal institutional structures, moreover, a number of publications, institutions and events continued to provide spaces for the relatively free exchange of ideas, and their dissemination to a wider public. Grimm's determination to preserve the Langen-Müller Verlag under Pezold, as well as his annual Lippoldsberger Dichtertage, suggest that they were more successful than the Nazis intended, but also demonstrate the constraints within which they were functioning. Moreover, even where the writers involved were ultimately unable to preserve the independence of the LMV, for example, their campaign provided them with a direct cause, giving an outlet for the expressions of both their vision for German literature and the frustrations they experienced as a result of the limitations imposed by the regime.

The völkisch cultural programme was always a political programme; the racial health of the German people would depend on the social structures established to order its existence. Thus völkisch politics promoted the idea that society needed to return to its natural, organic form, appealing to biological theories combined with a mysticism that suggested a metaphysical ordering of human life. True German literature made such things accessible to the German people and enabled their transmission from one generation to the next. This created a shared sense of obligation among völkisch writers; their ongoing efforts to protect and promote the spiritual interests of the German Volk even in the face of considerable opposition were motivated by their conviction that continued action was their duty. 
This also provided them after 1945 with a justification of their efforts to work with former members of the Nazi regime to complete the völkisch revolution.

This group of völkisch-nationalist writers also identified themselves against the republican forms adopted in West Germany after 1945. As a result, they were significant for the cultural debates of the time because they contested what Germany was becoming. Cultural change happens slowly and does not always map onto the political terrain. Moreover, popular identities have rarely been successfully imposed from above. Völkischnationalist writers tried to present an alternative solution for Germany to the one imposed by the occupying powers. They upheld old conceptions of German greatness and maintained the assertion of racial superiority in their demands not just for independence but also for equality on the world stage. In the light of their post-war success it can be assumed that they found a readership among a people conditioned to national rhetoric under the Nazis. Many 'normal' Germans welcomed their works, which were written by familiar names preaching a familiar ideology in the aftermath of war and national defeat. Völkisch-nationalism sought to present a political future that redeemed nationalism from the legacy of the Nazis and made it acceptable to post-war Germany. The successful articulation in West Germany of this ideology elucidates in particular the challenges which post-war Germans faced in 'confronting the past' and defining a new identity. 


\section{Select Bibliography}

\section{Published Sources}

Barthel, Ludwig Friedrich (ed.), Rudolf G. Binding: Die Briefe (Hamburg: Dulk, 1957). Baynes, Norman H. (ed.), The Speeches of Adolf Hitler, April Ig22 - August 1939: An English Translation of Representative Passages Arranged Under Subjects (New York: Howard Fertig, 1969).

Berggötz, Sven Olaf (ed.), Ernst Jünger Politische Publizistik IgIg bis 1933 (Stuttgart: Klett-Cotta, 200r).

Boberach, Heinz (ed.), Meldungen aus dem Reich, 1938-1945: Die geheime Lageberichte des Sicherheitsdienstes der SS (Herrsching: Pawlak, 1984).

Boehlich, Walter (ed.), Der Berliner Antisemitismusstreit (Frankfurt am Main: Insel, 1965). Boelcke, Willi A. (ed.), The Secret Conferences of Dr. Goebbels, October 1939 - March 1943 (London: Weidenfeld \& Nicolson, 1967).

Brenner, Hildegard, Die Kunstpolitik des Nationalsozialismus (Berlin: Rowohlt, 1963). Brenner, Hildegard, Ende einer bürgerlichen Kunst-Institution: Diepolitische Formierung der Preußischen Akademie der Künste ab 1933 (Stuttgart: DVA, 1972).

Deutsche Verwaltung für Volksbildung in der sowjetischen Besatzungszone, Liste der Auszusondernde Literatur, vorläufige Ausgabe nach dem Stand vom I. April I946 (Berlin: Zentralverlag, 1946).

Fröhlich, Elke (ed.), Die Tagebücher von Joseph Goebbels. Teil I: Aufzeichnungen. Sämtliche Fragmente, Volumes I-4 (Munich: Saur, 1987).

Fröhlich, Elke (ed.), Die Tagebücher von Joseph Goebbels, Teil II: Diktate, I94I-I945, Volumes I-Is (Munich: Saur, 1987).

Heiber, Helmut (ed.), Das Tagebuch von Joseph Goebbels, 1925/26; mit weiteren Dokumenten (Stuttgart: DVA, 1961).

Heiber, Helmut (ed.), Goebbels Reden: Band I, 1932-1939 (Düsseldorf: Droste, 197I). Hitler's Table Talk, I94I-1944, edited with an introductory essay, 'The Mind of Adolf Hitler, by H.R. Trevor-Roper (London: Weidenfeld \& Nicolson, I953).

Klöss, Erhard (ed.), Reden des Führers: Politik und Propaganda Adolf Hitlers, 1922-1945 (Munich: DTV, 1967).

Kordt, Erich, Nicht aus den Akten ... Die Wilhelmstrasse in Frieden und Krieg. Erlebnisse, Begegnungen und Eindrücke, 1928-1945 (Stuttgart: Union, 1950). 
Krieger, Karsten (ed.), Der 'Berliner Antisemitismusstreit' I879-I881: Kommentierte Quellenedition (Munich: Saur, 2003).

Lochner, Louis P. (trans. \& ed.), The Goebbels Diaries (London: H. Hamilton, 1948). Loewy, Ernst Literatur unterm Hakenkreuz: Das Dritte Reich und seine Dichtung. Eine Dokumentation (Frankfurt am Main: Hain, 1966).

Michaelis, Herbert and Schraepler, Ernst (eds), Ursachen und Folgen vom deutschen Zusammenbruch I9I8 und I945 bis zur staatlichen Neuordnung Deutschlands in der Gegenwart, vol. IX (Berlin: Wendler, 1964).

Ribbentropp, Joachim von, Zwischen London und Moskau: Erinnerungen und letzte Aufzeichnungen. Aus dem Nachlaß, herausgegeben von Annelies von Ribbentrop (Leoni am Starnberger See, 1954).

Revised statutes of the Alldeutscher Verband 28.8.1919 in Sacher, Hermann (ed.), Staatslexikon. Im Auftrag der Görres-Gesellschaft (5th revised edition, vol. I, Freiburg i.Br. 1926), pp. I26-131.

Seraphim, Hans-Günther (ed.), Das politische Tagebuch Alfred Rosenbergs (Munich: DTV, 1964).

Weizsäcker, Ernst von, Erinnerungen (Munich: List, 1950).

Wulf, Josef, Literatur und Dichtung im Dritten Reich: Eine Dokumentation (Gütersloh: Sigbert-Mohn, 1963).

Wysling, Hans (ed.), Dichter oder Schriftssteller? Der Briefwechsel zwischen Thomas Mann und Josef Ponten, I919-1930 (Bern: Francke, 1988).

\section{Official NSDAP Publications}

Amtsblatt des Thüringischen Ministeriums für Volksbildung Dreizehnter Jahrgang (Weimar, 1934).

Erckmann, Rudolf (ed.), Weimarer Reden des Großdeutschen Dichtertreffens 1938 (Hamburg: HAVA, 1939).

Erckmann, Rudolf (ed.), Die Dichtung im Kampf des Reiches: Weimarer Reden 1940 (Hamburg: HAVA, 194I).

Erckmann, Rudolf (ed.), Die Dichtung im kommenden Europa: Weimarer Reden I94I (Hamburg: HAVA, 1942).

Erckmann, Rudolf (ed.), Dichter und Krieger: Weimarer Reden 1942 (Hamburg: HAVA, 1943).

Reichsschrifttumskammer, Schriftsteller Verzeichnis (Leipzig, 1942). 
Reichsschrifttumsstelle beim Reichsministerium für Volksaufklärung und Propaganda, Vorschlagsliste für Dichterlesungen, 1938/39 (Berlin, 1938).

Reichsschrifttumsstelle beim Reichsministerium für Volksaufklärung und Propaganda, Weimarer Blätter: Festschrift zur ersten Grossdeutschen Buchwoche, 1938 (Berlin, 1939).

Werbe- und Beratungsamt für das deutsche Schrifttum beim Reichsministerium für Volksaufklärung und Propaganda, Weimarer Blätter: Festschrift zur Grossdeutschen Buchwoche, 1940 (Berlin, 194I).

Werbe- und Beratungsamt für das deutsche Schrifttum beim Reichsministerium für Volksaufklärung und Propaganda, Weimarer Blätter: Festschrift zur Kriegsbuchwoche 194I (Berlin, 1942).

\section{Contemporary Literature}

Alverdes, Paul and Benno von Mechow, Karl (eds), Das Innere Reich, Jahrgänge I-Io (Munich: LMV, 1934-1944).

Alverdes, Paul, Die Nördlichen (Berlin: Der weiße Ritter Verlag, 1922).

Alverdes, Paul, Die Pfeiferstube (Frankfurt am Main: Rütten \& Loening, 1929).

Alverdes, Paul, Reinhold oder die Verwandelten (Munich: Müller, 1931).

Alverdes, Paul, Die Freiwilligen (Munich: LMV, 1934).

Alverdes, Paul, Das Winterlager (Munich: LMV, 1935).

Alverdes, Paul, Eine Infanterie Division bricht durch (Munich: LMV, I943).

Bartels, Adolf, Die Dithmarscher: Historischer Roman in 4 Büchern (Kiel \& Leipzig: Lipsius \& Tischer, 1898).

Bartels, Adolf, Geschichte der deutschen Literatur, vol. I\&II (Leipzig: Avenarius, 1901/1902; 13th and I 4 th editions used, Braunschweig, 1934).

Bartels, Adolf, Das Weimarische Hoftheater als Nationalbühne für die deutsche Jugend: Eine Denkschrift (Weimar: Bohlau, 1905).

Bartels, Adolf, Heinrich Heine: Auch ein Denkmal (Dresden: Koch, 1906).

Bartels, Adolf, Handbuch zur Geschichte der deutschen Literatur (Leipzig: Avenarius, 1906).

Bartels, Adolf, Kinderland (Leipzig: Bürger, 1914).

Baumann, Gerhard, Jüdische und völkische Literaturwissenschaft: Ein Vergleich zwischen Eduard Engel und Adolf Bartels (Munich: Eher, 1936).

Benno von Mechow, Karl, Das ländliche Jahr (Munich: LMV, 1930). 
Benno von Mechow, Karl, Vorsommer (Munich: LMV, 1934).

Benno von Mechow, Karl, Leben und Zeit aus dem Land Österreich: ein Erinnerungsbuch (Freiburg im Breisgau: Herder, 1938).

Binding, Rudolf G., 'Sankt Georgs Stellvertreter' in Legenden der Zeit (Frankfurt am Main: Rütten \& Loening, I92I), pp. 6I-I23.

Binding, Rudolf G., Aus dem Kriege (Frankfurt am Main: Rütten \& Loening, 1925). Binding, Rudolf G., Erlebtes Leben (Frankfurt am Main: Rütten \& Loening, 1928). Binding, Rudolf G., Deutsche Jugend vor den Toten des Krieges (Frankfurt am Main: Rütten \& Loening, 1933).

Blunck, Hans Friedrich, Das Nibelungenlied: mit Bildern aus der hundeshagenschen Handschrift (Leipzig: Bibliographisches Institut, 1934).

Blunck, Hans Friedrich, Unwegsame Zeiten (Mannheim: Kessler, 1952).

Boschan, Richard, 'Die Zukunft unserer nationalen Vereine', in Deutsche Zeitung, No. 420, 20th September 1919, p. 7.

Brehm, Bruno, Apis und Este: Ein Franz Ferdinand Roman (Munich: Piper, 194I).

Bruneck, Hans Martin von, Adolf Bartels als Dichter: eine Studie (Munich: Callwey, 1907).

Chamberlain, Houston Stewart, Richard Wagner (Munich: Bruckmann, I895).

Chamberlain, Houston Stewart, Immanuel Kant: Die Persönlichkeit als Einführung in das Werk (Munich: Bruckmann, 1905).

Chamberlain, Houston Stewart, Goethe (Munich: Bruckmann, I912).

Chamberlain, Houston Stewart, Die Grundlagen des neunzehnten Jahrhunderts (Munich: Bruckmann, I899; edition used: 1935).

Claß, Heinrich (alias Daniel Frymann), Wenn ich Kaiser wär': Politische Wahrheiten und Notwendigkeiten (Leipzig: Dieterichs, 1912).

Cölln, Detlef (ed.), Adolf Bartels; der völkische Vorkämpfer und der Dichter mit einer Auswabl seiner Gedichte (Munich: Callwey, 1937).

Diederichs, Eugen, Der deutsche Buchbandel der Gegenwart in Selbstdarstellungen: Zweiter Band, Heft I: Eugen Diederichs (Leipzig: Meiner, 1927).

Engel, Eduard, Geschichte der deutschen Literatur von den Anfängen bis in die Gegenwart, vols. I \& II (Leipzig: Freytag, 1908).

Ettighoffer, Paul C., Gespenster am toten Mann (Cologne: Gilde-Verlag, 1931).

Ettighoffer, Paul C., Feldgrau schafft Dividende (Cologne: Gilde-Verlag, 1932).

Ettighoffer, Paul C., Von der Teufelsinsel zum Leben (Cologne: Gilde-Verlag, 1932).

Ettighoffer, Paul C., Verdun (Gütersloh: Bertelsmann, 1936).

Fallada, Hans, Wer einmal aus der Blechnapffrißt (Berlin: Rowohlt, 1934).

Frenssen, Gustav, Die Sandgräfin (Berlin: Bong \& C., I895).

Frenssen, Gustav, Die drei Getreuen (Berlin: Grote, I898).

Frenssen, Gustav, Jörn Uhl (Berlin: Grote, I90I). 
Frenssen, Gustav, Das Heimatsfest: Schauspiel in 5 Akten (Berlin: Grote, 1903).

Frenssen, Gustav, Hilligenlei (Berlin: Grote, 1905).

Frenssen, Gustav, Peter Moors Fahrt nach Südwest: Ein Feldzugsbericht (Berlin: Grote 1906; editions used: $1920 \& 1942)$.

Frenssen, Gustav, Sönke Erichsen: Schauspiel in drei Aufzügen (Berlin: Grote, 1912).

Frenssen, Gustav, Grübeleien (Berlin: Grote, 1920).

Frenssen, Gustav, Otto Babendiek (Berlin: Grote, 1926).

Frenssen, Gustav, Der Glaube der Nordmark (Berlin: Truckenmüller, 1936).

Frenssen, Gustav, Der Weg unseres Volkes (Berlin: Grote, 1938).

Freytag, Gustav, Soll und Haben (1855; Edition used: Munich: Droemeische Verlags. Anstalt Knaur, 1959).

Freytag, Gustav, 'Über den Antisemitismus: Eine Pfingsbetrachtung' in Neue Freie Presse (Vienna, 2Ist May I893).

Goebbels, Joseph, Michael: Ein deutsches Schicksal in Tagebuchblättern (Munich: Eher, 1929).

Goebbels, Joseph, Signale der neuen Zeit: 25 ausgewählte Reden (Munich: Eher, 1937).

Goebbels, Joseph, Kampf um Berlin (Munich: Eher, 1939).

Gollancz, Victor, Our Threatened Values (London: Gollancz, 1946).

Grimm, Hans, Die Grobbelaars: Ein Trauerspiel in vier Aufzügen (Berlin-Charlottenburg: Vita Deutsches Verlagshaus, 1907).

Grimm, Hans, Afrikafahrt-West: Ein Reisebuch und ein Einführungsbuch (Frankfurt a/M: Rütten \& Loening, 1913).

Grimm, Hans, Südafrikanische Novellen (Frankfurt a/M: Rütten \& Loening, 1913).

Grimm, Hans, Den Gang durch den Sand und andere Geschichten aus südafrikanischer Not (Munich: Langen, 1916).

Grimm, Hans, Der Ölsucher von Duala (Berlin: Ullstein, 1918).

Grimm, Hans, 'Um die Dichterakademie / Gedanken,' in Süddeutsche Monatshefte, No. 28 (1930/1931).

Grimm, Hans, Lüderitzland: Sieben Begebenheiten (Munich: Langen-Müller, 1934). Grimm, Hans, Volk ohne Raum: Ein deutsches Schicksal (First published: Munich: Langen, 1926; Edition consulted: Lippoldsberg: Klosterhaus-Verlag, 1956).

Grimm, Hans, Englische Rede: Wie ich den Engländer sehe (Gütersloh: Bertelsmann, 1938).

Grimm, Hans, Die Erzbischofschrift: Antwort eines Deutschen (Göttingen: Plesse, 1950).

Grimm, Hans, Warum - woher - aber wohin? Vor, unter und nach der geschichtlichen Erscheinung Hitler (Lippoldsberg: Klosterhaus-Verlag, 1954).

Grimm, Hans, Leben in Erwartung (Lippoldsberg: Klosterhaus-Verlag, 1972).

Grimm, Hans, Über mich selbst und über meine Arbeit (Lippoldsberg: KlosterhausVerlag, 1975). 
Grimm, Hans, Mehr nationale Würde und mehr Wabrheit (Lippoldsberg: Klosterhaus-Verlag, 1975).

Hanseatische Verlagsanstalt Aktiengesellschaft, Hamburg, Geschäftsbericht, 1934-1939 (Hamburg).

Hitler, Adolf, Mein Kampf, vols. I\&II (Munich: Eher, 1925-1926; Edition consulted: 1936).

Jacoby, Siegfried, 'Der Weg des deutschen Buches. Verlagsort München,' in Berliner Tageblatt, 6.10.1928.

Johst, Hanns, Die Stunde der Sterbenden (Leipzig: Weiße Bücher, 1914).

Johst, Hanns, Wegwärts (Munich: Delphin-Verlag, 1915).

Johst, Hanns, Der junge Mensch (Munich: Delphin-Verlag, 1916).

Johst, Hanns, Der Einsame (Munich: Delphin-Verlag, 1917).

Johst, Hanns, 'Bekenntnis zur Bühne' in Das literarische Echo, No. 25, I923, pp. 68I -683 .

Johst, Hanns, Propheten (Munich: Langen, 1923).

Johst, Hanns, 'Vom Ethos der Begrenzung' in Wissen und Gewissen (Essen: Schlingloff, i924).

Johst, Hanns, Thomas Paine (Munich: Langen, 1927).

Johst, Hanns, Schlageter (Munich: Langen-Müller, 1933).

Jünger, Ernst, Der Kampf als inneres Erlebnis (Berlin: Mittler, 1922).

Jünger, Ernst, 'Revolution und Idee' in Völkischer Beobachter, 23/24. September 1923.

[The complete is reproduced in Sven Olaf Berggötz (ed.), Ernst Jünger Politische

Publizistik I9Ig bis I933 (Stuttgart: Klett-Cotta, 200I)].

Jünger, Ernst, Das Wäldchen I2s: Eine Chronik aus den Grabenkämpfen IgI8 (Berlin:

Mittler, 1925).

Jünger, Ernst, The Sword of Steel (1929 translation of In Stablgewittern, London, 1929). Jünger, Ernst, Der Arbeiter: Herrschaft und Gestalt (Hamburg: HAVA, 1932).

Jünger, Ernst, Auf den Marmorklippen (Hamburg: HAVA, 1939).

Kolbenheyer, Erwin Guido, Amor Dei: Ein Spinoza Roman (Munich: Müller, 1908).

Kolbenheyer, Erwin Guido, Meister Joachim Pausewang (Munich: Müller, I910).

Kolbenheyer, Erwin Guido, Die Kindheit von Paracelsus (Munich: Müller, 1917).

Kolbenheyer, Erwin Guido, Das Gestirn von Paracelsus (Munich: Müller, 1921).

Kolbenheyer, Erwin Guido, Das dritte Reich des Paracelsus (Munich: Müller, 1925).

Kolbenheyer, Erwin Guido, Jagd ihn - ein Mensch (Munich: Müller, 1931).

Kolbenheyer, Erwin Guido, Der Lebensstand der geistig Schaffenden und das neue Deutschland (Munich: Langen-Müller, 1934).

Kolbenheyer, Erwin Guido, Die Baubütte: Grundzüge einer Metaphysik der Gegenwart (Revised edition, Munich: Langen-Müller, 194I). 
Kolbenheyer, Erwin Guido, Sebastian Karst: Über sein Leben und über seine Zeit, 3 Volumes (Gartenberg bei Wolfratshausen: Kolbenheyer-Gesellschaft, 1954-1957).

Klabund, Deutsche Literaturgeschichte in einer Stunde: von den ältesten Zeiten bis zur Gegenwart (Leipzig: Dürr \& Weber, 192I).

König, Eberhard, Hurrapatriotismus und Begeisterung: Eine Festtagsbetrachtung (Berlin: Schriftenverband, 1909).

Kubizek, August, Hitler, mein Jugendfreund (Graz \& Stuttgart: Stockerer, 1995).

Langbehn, Julius, Rembrandt als Erzieher (Leipzig: Hirschfeld, I890; edition used 1922).

Lagarde, Paul de, Deutsche Schriften (Göttingen: Dieterich, I878).

Lagarde, Paul de, Schriften für das deutsche Volk (Munich: Deutsche Buchgemeinschaft, 1934).

Lehmann, Melanie (ed.), Verleger J.F. Lehmann: Ein Leben im Kampffür Deutschland. Lebenslauf und Briefe (Munich: Lehmann, 1935).

Löns, Hermann, Der Wehrwolf (Jena: Diederichs, 1912).

Loose, Walter (ed.), Festgabe zum sechzigsten Geburtstag von Adolf Bartels (Leipzig: Haessel, 1922).

Lorenz, Ludwig, AdolfBartels und seine Dichtungen: eine Studie (Dresden and Leipzig: Koch, 1908).

Marr, Wilhelm, Der Sieg des Judentums über das Germanentum (Bern: Costenoble, I879).

Meyer, Hermann, Der deutsche Mensch, 2. Buch: Deutsche Volksgemeinschaft (Munich: Lehmanns, 1925).

Moeller van Bruck, Arthur, Die moderne Literatur (Berlin and Leipzig: Schuster \& Loeffler, 1902).

Moeller van den Bruck, Arthur, Die Deutschen, 8 Volumes (Minden i.W: Bruns, 1904-1910).

Moeller van den Bruck, Arthur, Die Zeitgenossen. Die Geister - die Menschen (Minden i.W: Bruns, 1906).

Möller van den Bruck, Arthur, Nationalkunst für Deutschland (Berlin: Vaterländischer Schriftenverband, 1909).

Moeller van den Bruck, Arthur, Die italienische Schönheit (Munich: Piper, 1913).

Moeller van den Bruck, Arthur, Der Preußische Stil (Munich: Piper, 1916).

Moeller van den Bruck, Arthur, Das Dritte Reich (Berlin: Ring-Verlag, 1923; edition consulted: HAVA, 1931).

Moeller van den Bruck, Arthur, Das Recht der jüngen Völker (Berlin: Der Nahen Osten, 1932).

Nadler, Josef, Literaturgeschichte der deutschen Stämme und Landschaften, 4 volumes (Regensburg: Habbel, 1912-1928). 
Remarque, Erich Maria, Im Westen nichts Neues (Berlin: Propyläen, 1929).

Rosenberg, Alfred, Der Mythos des zwanzigsten Jahrhunderts: Eine Wertung der seelisch-geistigen Gestaltenkämpfe unserer Zeit (Munich: Eher, 1930; edition consulted: Munich 1933).

Roth, Alfred (Pseudonym: Otto Armin), Die Juden im Heer (Hamburg: HAVA, 1919).

Roth, Alfred (Pseudonym: Otto Armin), Die Juden in den Kriegsgesellschaften (Hamburg: HAVA, 1920).

Salomon, Ernst von (Pseudonym: Ernst Friedrich), 'Der Soldat in Schrifttum und Film' in Deutsche Front, Year 5, Ist June edition, 1928.

Salomon, Ernst von (pseud. Ernst Friedrich), 'Stahlhelm und Rotfront' in Deutsche Front, 3 rd June edition, 1928.

Salomon, Ernst von, Die Geächteten (Berlin: Rowohlt, 1930).

Salomon, Ernst von, Die Kadetten (Berlin: Rowohlt, 1933; edition consulted: 1957).

Salomon, Ernst von, Der Fragebogen (Hamburg: Rowohlt 1951; edition consulted 1993).

Schäfer, Wilhelm, Die dreizehn Bücher der deutschen Seele (Munich: Müller, 1922).

Schäfer, Wilhelm, Der deutsche Gott (Munich: Müller, 1923).

Schäfer, Wilhelm, Mein Lebenswerk: Dankrede bei der Verleihung des Rheinischen Literaturpreises in Köln am I3. November 1937 (Munich: Langen-Müller, 1937).

Stoecker, Adolf, Die Bewegungen der Gegenwart im Lichte der christlichen Weltanschauung (Heidelberg: Winter, I88I).

Schäfer, Wilhelm, Krieg und Dichtung (Weimar: Gesellschaft der Bibliophilen, 1944).

Strauß, Wilhelm, Lebenstanz (Munich: Langen-Müller, 1940).

Treitschke, Heinrich von, Deutsche Geschichte im neunzehnten Jahrhundert, 4 volumes. (Leipzig: Hirzel, I879-1894).

Treitschke, Heinrich von, 'Unsere Aussichten', Preußische Jahrbücher 44 (1879), pp. 560-576.

Treitschke, Heinrich von, 'Noch einige Bemerkungen zur Judenfrage', Preußische Jahrbücher 45 (1880), pp. 85-95.

Voigt-Diederichs, Helene, Zwischen Lipp' und Kelchesrand (Wiesbaden: Verlag des Volksbildungsvereins, 1905).

Wiechert, Ernst, Der Dichter und die Zeit: Rede gehalten am I6. April im Auditorium Maximum der Universität München (Zurich: Artemie-Verlag, 1945).

Wiechert, Ernst, Der Totenwald (Berlin: Aufbau, 1947; edition consulted, Berlin: Ullstein, 1996).

Winkelhagen, Juan, Das Rätsel vom Skagerrak (Leipzig: Weicher, 1925).

Winnig, August, Vom Proletariat zum Arbeitertum (Hamburg: HAVA, 1930).

Zöberlein, Hans, Der Glaube an Deutschland: Ein Kriegserleben von Verdun bis zum Umsturz (Munich: Eher, 1931). 


\section{Secondary Literature}

Amman, Klaus and Berger, Albert (eds), Österreichische Literatur der dreißiger Jahre

(Vienna: Böhlau, 1985).

Anderson, Benedict, Imagined Communities: Reflections on the Origin and Spread of Nationalism (Revised edition, London: Verso, I991).

Anderson, Margaret Lavinia, Practicing Democracy: Elections and Political Culture in Imperial Germany (Princeton: Princeton University Press, 2000).

Applegate, Celia, A Nation of Provincials: The German Idea of Heimat (Berkeley: University of California Press, 1990).

Arendt, Hannah, The Origins of Totalitarianism (New York: Harcourt Brace, 1973). Assmann, Aleida and Ute Frevert, Geschichtsvergessenheit; Geschichtsversessenheit: Vom Umgang mit deutschen Vergangenheiten nach 1945 (Stuttgart: Deutsche Verlags-Anstalt, 1999).

Assmann, Aleida, Geschichte im Gedächtnis: Von der individuellen Erfahrung zur öffentlichen Inszenierung (Munich: Beck, 2007).

Ayçoberry, Pierre, The Social History of the Third Reich, 1933-1945 (New York: The New Press 1999).

Barbian, Jan-Pieter, Literaturpolitik im 'Dritten Reich': Institutionen, Betätigungsfelder (Frankfurt am Main: Buchhändler-Vereinigung, 1993).

Berglund, Gisela, Der Kampf um den Leser im Dritten Reich: Die Literaturpolitik der 'Neuen Literatur' (Will Vesper) und der 'Nationalsozialistischen Monatshefte' (Worms: Heintz, 1980).

Berman, Sheri, 'Civil Society and the Collapse of the Weimar Republic', World Politics 49 (April I997), 40I-429.

Bermann-Fischer, Gottfried, Wanderer durch ein Jabrhundert (Frankfurt am Main: Fischer, 1994).

Blackbourn, David and Eley, Geoff, The Peculiarities of German History: Bourgeois Society and Politics in Nineteenth-Century Germany (Oxford: Oxford University Press, 1984).

Blinkhorn, Martin (ed.), Fascists and Conservatives: The radical right and the establishment in twentieth-century Europe (London: Unwin Hyman, 1990).

Boa, Elizabeth and Palfreyman, Rachel, Heimat: A German Dream. Regional Loyalties and National Identity in German Culture 1890-19go (Oxford: Oxford University Press, 2000).

Bollmus, Reinhard, Das Amt Rosenberg und seine Gegner: Zum Machtkampfim nationalsozialistischen Herrschaftssystem (Stuttgart: Deutsche Verlags-Anstalt, 1970). 
Bookbinder, Paul, Weimar Germany: The Republic of the Reasonable (Manchester: Manchester University Press, 1996).

Bracher, Karl Dietrich, Die deutsche Diktatur: Entstehung, Struktur, Folgen des Nationalsozialismus (Cologne and Berlin: Kiepenhauer \& Witsch, 1969).

Bramsted, Ernest K., Goebbels and National Socialist Propaganda, I925-1945 (Ann Arbor: Michigan State University Press, 1965).

Bramwell, Anna, Blood and Soil: Richard Walther Darré and Hitler's 'Green Party' (Bourne End: Kensal, 1985).

Braunthal, Gerard, Socialist Labor and Politics in Weimar Germany: The German Federation of Trade Unions (Hamden, CT: Archon Books, 1978).

Breuer, Dieter, Geschichte der literarischen Zensur in Deutschland (Heidelberg: Quelle \& Meyer, 1982).

Breuer, Stefan, Anatomie der konservativen Revolution (Darmstadt: Wissenschaftliche Buchgesellschaft, 2nd revised edition, 1995).

Breuer, Stefan, Die Völkischen in Deutschland (Darmstadt: Wissenschaftliche Buchgesellschaft, 2008).

Brockmann, Stephen, German Literary Culture at the Zero Hour (Rochester, NY: Camden House, 2004).

Broszat, Martin, Nach Hitler: Der schwierige Umgang mit unserer Geschichte (Munich: Oldenbourg, 1987).

Burleigh, Michael, The Third Reich: A New History (London: Pan, 2000).

Busch, Stefan, 'Und gestern, da hörte uns Deutschland': NS Autoren in der Bundesrepublik. Kontinuität und Diskontinuität bei Friedrich Griese, Werner Beumelburg, Eberhard Wolfgang Möller und Kurt Ziesel (Würzburg: Königshausen \& Neumann, 1998).

Caemmerer, Christiane and Walter Delabar (eds), Dichtung im Dritten Reich: Zur Literatur in Deutschland, I933-1945 (Opladen: Westdeutscher Verlag, 1996).

Cecil, Robert, The Myth of the Master Race: Alfred Rosenberg and Nazi Ideology (London: Batsford, 1972).

Chickering, Roger, We Men who feel most German: A Cultural Study of the Pan-German League, I886-1914 (Boston: Allen \& Unwin, 1984).

Chickering, Roger, Imperial Germany and the Great War, IgI4-IgI8 (Cambridge: Cambridge University Press, 1998).

Cohn, Norman, Warrant for Genocide (London: Eyre \& Spottiswoode, 1967).

Conrady, Karl Otto, Literatur und Germanistik als Herausforderung: Skizzen und Stellungen (Frankfurt am Main: Suhrkamp, 1974).

Crystall, Andreas, Gustav Frenssen: Sein Weg vom Kulturprotestantismus zum Nationalsozialismus (Gütersloh: Gütersloher Verlagshaus, 2002). 
Dahm, Volker, 'Nationale Einheit und partikulare Vielfalt. Zur Frage der kulturpolitischen Gleichschaltung im Dritten Reich,' Viertelsjahresheft für Zeitgeschichte 43, Heft 2 (April 1995), pp. 221-265.

Darnton, Robert, 'Reading, Writing and Publishing in Eighteenth-Century France: A Case Study in the Sociology of Literature', in Felix Gilbert and Stephen Graubard (eds), Historical Studies Today (New York, 1972), pp. 238-280.

Denkler, Horst and Lämmert, Eberhard (eds), 'Das war ein Vorspiel nur ...' Berliner Colloquium zur Literaturpolitik im 'Dritten Reich'(Berlin: Akademie der Künste, 1985).

Denkler, Horst and Prümm, Karl (eds), Die deutsche Literatur im Dritten Reich: Themen - Traditionen - Wirkungen (Stuttgart: Reclam, 1976).

Dohnke, Kay and Stein, Dietrich (eds), Gustav Frenssen in seiner Zeit: Von der Massenliteratur im Kaiserreich zur Massenideologie im NS-Staat (Heide: Boyens, 1997).

Dorpalen, Andreas, Heinrich von Treitschke (New York and London: Kennikat Press, 1973).

Dubiel, Helmut, Niemand ist frei von der Geschichte: Die nationalsozialistische Herrschaft in den Debatten des Deutschen Bundestages (Munich: Hanser, 1999).

Düsterberg, Rolf, Hans Johst: 'Der Barde der SS.' Karrieren eines deutschen Dichters (Paderborn: Schöningh, 2004).

Eksteins, Modris, The Limits of Reason: The German Democratic Press and the Collapse of Weimar Democracy (Oxford: Oxford University Press, 1975).

Eley, Geoff, Reshaping the German Right: Radical Nationalism and Political Change after Bismarck (New Haven: Yale University Press, 1980).

Eley, Geoff and Ronald Grigor Suny (eds), Becoming National (Oxford: Oxford University Press, 1996).

Elias, Norbert, Studien über die Deutschen: Machtkämpfe und Habitusentwicklung im 19. und 20. Jahrbundert (Frankfurt am Main: Suhrkamp, 1989).

Elliott, C.J., 'The Kriegervereine and the Weimar Republic', Journal of Contemporary History 10, Issue I (January 1975), pp. 109-I29.

Evans, Richard, The Coming of the Third Reich (London: Penguin, 2003).

Evans, Richard and Pogge von Strandmann, Hartmut (eds), The Coming of the First World War (Oxford: Clarendon Press, 1988).

Field, Geoffrey G., Evangelist of Race: The Germanic Vision of Houston Stewart Chamberlain (New York: Columbia University Press, 198I).

Fischler, Hersch, 'Helle Zukunft - dunkle Vergangenheit. Wie der deutsche Bertelsmann-Konzern seine Geschichte systematisch schönt', Die Weltwoche, Nr. 44, 29th October 1998, p. 39.

Franke, Manfred, Grimm ohne Glocken: Ambivalenzen in politischen Denken und Handeln des Schriftstellers Hans Grimm (Cologne: S.H. Verlag, 2009). 
Frei, Norbert, Vergangenheitspolitik: Die Anfänge der Bundesrepublik und die NSVergangenheit (Munich: Beck, 1997).

Frei, Norbert, 1945 und Wir: Das Dritte Reich im Bewußtsein der Deutschen (Munich: Beck, 2005).

Friedländer, Saul, Nazi Germany and the Jews: The Years of Persecution, 1933-1939 (London: Weidenfeld \& Nicolson, 1997).

Friedländer, Saul, Frei, Norbert, Rendtorff, Trutz, and Wittmann, Reinhard, Bertelsmann im Dritten Reich (Munich: Bertelsmann, 2002).

Friedrich, Jörg, Der Brand: Deutschland im Bombenkrieg, I940-I945 (Munich: Propyläen, 2002).

Fritzsche, Peter, Reading Berlin, Igoo (Cambridge, MA: Harvard University Press, 1996). Fritzsche, Peter, Germans into Nazis (Cambridge, MA: Harvard University Press, 1998).

Fulda, Bernhard, Press and Politics in the Weimar Republic (Oxford: Oxford University Press, 2009).

Fuller, Steven Nyole, The Nazis' Literary Grandfather: Adolf Bartels and Cultural Extremism, I871-1945 (New York: Peter Lang, 1997).

Gay, Peter, Weimar Culture: The Outsider as Insider (London: Secker \& Warburg, 1968).

Gehring, Hansjörg, Amerikanische Literaturpolitik in Deutschland, 1945-1953: Ein Aspekt des Re-Education-Programms (Stuttgart: Deutsche Verlags-Anstalt, 1976).

Gellately, Robert, Backing Hitler: Consent and Coercion in Nazi Germany (Oxford: Oxford University Press, 200I).

Geyer-Ryan, Helga, 'Trivialliteratur im Dritten Reich: Beobachtungen zum Groschenroman', in Ralf Schnell (ed.), Literaturwissenschaft und Sozialwissenschaften Io: Kunst und Kultur im deutschen Faschismus (Stuttgart: Metzler, 1978), pp. 217-260.

Glaser, Hermann, Spießer Ideologie (Freiburg: Verlag Wissenschaft und Politik, 1964). Glaser, Horst Albert and Bormann, Alexander von (eds), Deutsche Literatur, eine Sozialgeschichte. Band g: Weimarer Republik - Drittes Reich: Avantgardismus, Parteilichkeit, Exil, I9I8-1945 (Reinbek: Rowohlt, 1989).

Goldhagen, Daniel Jonah, Hitler's Willing Executioners: Ordinary Germans and the Holocaust (London: Little Brown, 1996).

Goodrick-Clarke, Nicholas, The Occult Roots of Nazism: The Ariosophists of Austria and Germany, I890-1935 (Wellingborough: Aquarian Press, 1985).

Grenville, Anthony, Cockpit of Ideologies. The Literature and Political History of the Weimar Republic (Bern: Peter Lang, 1995).

Griffin, Roger (ed.), International Fascism: Theories, Causes and the New Consensus (London: Arnold, 1998). 
Gumbel, Emil J., Vom Fememord zur Reichskanzlei (Heidelberg: Lambert Schneider, 1962).

Gurion, Waldemar, 'Conservative Revolution in Germany', The Review of Politics, vol. 13, No. 3 (July i95I), p. 395.

Haffner, Sebastian, Von Bismarck zu Hitler: Ein Rückblick (Munich: Kindler, 1989).

Hale, Oron J., The Captive Press in the Third Reich (Princeton: Princeton University Press, 1964).

Hamilton, Richard F., Who Voted for Hitler? (Princeton: Princeton University Press, 1982).

Hamman, Brigitte, Hitler's Vienna: A Dictator's Apprenticeship (Oxford: Oxford University Press, 1999).

Hansen, Randall, Fire and Fury: the Allied Bombing of Germany 1942-1945 (Toronto: Doubleday 2008).

Herf, Jeffrey, Reactionary Modernism: Technology, Culture and Politics in Weimar and the Third Reich (Cambridge: Cambridge University Press, 1984).

Hermand, Jost, Kultur im Wiederaufbau: Die Bundesrepublik Deutschland, 1945-1965 (Munich: Nymphenburger, 1986).

Hermand, Jost, Der alte Traum vom neuen Reich: Völkische Utopien und Nationalsozialismus (Frankfurt am Main: Athenäum, 1988).

Hermand, Jost, Die deutschen Dichterbünde: Von den Meistersingern bis zum PENClub (Cologne: Böhlau, 1998).

Hillesheim, Jürgen and Elisabeth Michael, Lexikon nationalsozialistischer Dichter: Biographien - Analysen - Bibliographien (Würzburg: Königshausen \& Neumann, 1993).

Hobsbawm, Eric, Nations and Nationalism since 1870: Programme, Myth, Reality (Cambridge: Cambridge University Press, 1990).

Hobsbawm, Eric, Age of Extremes: The Short Twentieth Century, 19I4-IggI (London: Abacus, 1995).

Hoenicke Moore, Michaela, Know your Enemy: The American Debate on Nazism, 1933-1945 (Cambridge: Cambridge University Press, 2010).

Hohendahl, Peter (ed.), A History of German Literary Criticism, 1730-1980 (Lincoln: University of Nebraska Press, 1988).

Huder, Walter, 'Die sogenannte Reinigung. Die "Gleichschaltung" der Sektion für Dichtkunst der Preußischen Akademie der Künste 1933', Exilforschung: Ein Internationales Jahrbuch, Band 4: Dasjüdische Exil und andere Themen (1986), pp. 144-159.

Iber, Harald, Christlicher Glaube oder rassischer Mythus: Die Auseinandersetzung der Bekennenden Kirche mit Alfred Rosenbergs: 'Der Mythos des 2o. Jahrhunderts' (Frankfurt am Main: Peter Lang, 1987). 
Jens, Inge, Dichter zwischen rechts und links: Die Geschichte der Sektion für Dichtkunst an der Preußischen Akademie der Künste (Leipzig: Kiepenhauer, 1994).

Jens, Walter, Statt einer Literaturgeschichte (Pfüllingen: Neske, 1962).

Kahn-Freund, Otto, Labour Law and Politics in the Weimar Republic (Oxford: Basil Blackwell, i98I).

Kedourie, Elie, Nationalism (4th Edition: Oxford: Blackwell, 1994).

Kershaw, Ian, Popular Opinion and Political Dissent in the Third Reich: Bavaria, 1933-1945 (Oxford: Clarendon Press, 1982).

Kershaw, Ian, Hitler, 1898-1936: Hubris (London: Penguin, 1998).

Kershaw, Ian, Hitler, 1937-1945: Nemesis (London: Penguin, 2000).

Ketelsen, Uwe-Karsten, Völkisch-nationale und nationalsozialistische Literatur in Deutschland I890-1945 (Stuttgart: Metzler, 1976).

Ketelsen, Uwe-Karsten, Literatur und Drittes Reich (Schernfeld: SH-Verlag, 1992).

Klemperer, Klemens von, Germany's new Conservatism (Princeton: Princeton University Press, 1957).

Klemperer, Victor, LTI: Notizbuch eines Philologen (Leipzig: Reclam, 1975).

Koch, Gerd, '1936: Dichtertreffen bei Hans Grimm in Lippoldsberg', Zeitschrift für Germanistik (1994), No. 2, pp. 337-349.

Kocka, Jürgen, 'Asymmetrical Historical Comparison: The Case of the German Sonderweg', History and Theory 38 (1999), No. I, pp. 40-50.

Kohler, Joachim, Wagner's Hitler: The Prophet and his Disciple (Oxford: Polity, 2000).

Kohn, Hans, The Mind of Germany (London: Macmillan, 1966).

Kondylis, Panajotis, Konservatismus: Geschichtlicher Gehalt und Untergang (Stuttgart: Klett-Cotta, 1986).

König, Christoph (ed.), Internationales Germanisten Lexikon (Berlin: De Gruyter, 2003).

Kreis, Georg; Krumeich, Gerd; Ménudier, Henri; Mommsen, Hans; Sywottek Arnold (eds), Alfred Toepfer, Stifter und Kaufmann: Bausteine einer Biographie - Kritische Bestandsaufnahme (Hamburg: Christians, 2000).

Kreuz, Leo, Das Kuratorium Unteilbares Deutschland: Aufbau, Programmatik, Wirkung (Opladen: Lesker \& Budrich, 1979).

Kunisch, H. (ed.), Handbuch der deutschen Gegenwartsliteratur (Munich: Nymphenburger Verlagshandlung, 1965).

Lebzelter, Gisela C., Political Anti-Semitism in England, 1918-1939 (London: Macmillan, 1978).

Lohalm, Uwe, Völkischer Radikalismus: Die Geschichte des Deutschvölkischen Schutzund Trutz-Bundes 1919-1923 (Hamburg: Leibniz-Verlag, 1970).

Lokatis, Siegfried, 'Hanseatische Verlagsanstalt': Politisches Buch-Marketing im 'Dritten Reich'(Frankfurt am Main: Buchhändler-Vereinigung, 1992). 
Malinowski, Stephan, Vom König zum Führer: Zum Verhältnis von Adel und Nationalsozialismus. Dokumentation einer Veranstaltung am 9. Juli 2004 im Studienzentrum Karl-Marx-Haus in Trier (Berlin: Akad.-Verlag, 2003).

Mallmann, Marion, 'Das innere Reich': Analyse einer konservativen Kulturzeitschrift im Dritten Reich (Bonn: Bouvier, 1978).

Matoni, Jürgen, 'Die Juden in Gustav Freytags Werken', Oberschlesisches Jahrbuch 8 (1985), pp. 107-116.

Mergel, Thomas, 'Das Scheitern des deutschen Tory-Konservatismus. Die Umformung der DNVP zu einer rechtsradikalen Partei 1928-1932', Historische Zeitschrift 276, Heft 2 (April 2003), pp. 323-368.

Meyer, Andreas, Die Verlagsfusion Langen-Müller: Zur Buchmarkt-und Kulturpolitik des Deutschnationalen Handlungsgehilfen-Verbands in der Endphase der Weimarer Republik (Frankfurt am Main: Buchhändler-Vereinigung, 1989).

Midgley, David, Writing Weimar: Critical Realism in German Literature, 19I8-1933 (Oxford: Oxford University Press, 2000).

Milfull, John (ed.), Why Germany? National Socialist Anti-Semitism and the European Context (Oxford: Berg, 1993).

Mittenzwei, Werner, Der Untergang einer Akademie oder die Mentalität des ewigen Deutschen (Berlin: Aufbau, 1992).

Mohler, Armin, Die konservative Revolution in Deutschland, 1918-1932: Ein Handbuch (Revised edition: Darmstadt: Wiss. Buchgesellschaft, 1989).

Möller, Horst, Weimar: Die unvollendete Demokratie (Munich: dtv, 1997).

Mosse, George L., The Culture of Western Europe: The Nineteenth and Twentieth Centuries; an Introduction (London: John Murray, 1963).

Mosse, George L., The Crisis of German Ideology: Intellectual Origins of the Third Reich (New York: Schocken, 1964).

Mosse, George L., The Nationalisation of the Masses: Political Symbolism and Mass Movements in Germany from the Napoleonic Wars through the Third Reich (New York: Fertig, 1975).

Mosse, George L., Masses and Man: Nationalist and Fascist Perceptions of Reality (New York: Fertig, 1980).

Mosse, George L., Confronting History: A Memoir (Madison: University of Wisconsin Press, 2000).

Müller, Hans-Harald, Der Krieg und die Schriftsteller: Der Kriegsroman der Weimarer Republik (Stuttgart: Metzler, 1986).

Müller, Hans-Harald, 'Politics and the War Novel: the Political Conception and Reception of Novels about the First World War' in Dove, Richard and Lamb, Stephen (eds), German Writers and Politics, 1918-1939 (Basingstoke, 1992), pp. 108-109. 
Müller, Jan Werner, A Dangerous Mind: Carl Schmitt in Post-War European Thought (New Haven: Yale University Press, 2003).

Muschg, Walter, Die Zerstörung der deutschen Literatur (Bern: Francke, 1956).

Neumann, Thomas, Völkisch-nationale Hebbelrezeption: Adolf Bartels und die Weimarer Nationalfestspiele (Bielefeld: Aisthesis Verlag, 1997).

Nevin, Thomas, Ernst Jünger and Germany: Into the Abyss, 1914-1945 (London: Constable, 1997).

Nicholls, Anthony J., Weimar and the Rise of Hitler (Basingstoke: Macmillan, 1991).

Niven, Bill (ed.), Germans as Victims: Remembering the Past in Contemporary Germany (Basingstoke: Macmillan, 2006).

Noack, Paul, Ernst Jünger: Eine Biographie (Berlin: Fest, 1998).

Noakes, Jeremy, 'Leaders of the People? The Nazi Party and German Society', Journal of Contemporary History 39 (2004), no. 2, pp. I89-212.

Overy, Richard, War and the Economy in the Third Reich (Oxford: Oxford University Press, 1994).

Özkirimli, Umut, Theories of Nationalism: A Critical Introduction (Basingstoke: Macmillan, 2000).

Patch, William L., Jnr., Christian Trade Unions in the Weimar Republic, I9I8-1933: The Failure of 'Corporate Pluralism' (New Haven: Yale University Press, 1985).

Pfanner, Helmut F., Hanns Johst: Vom Expressionismus zum Nationalsozialismus (The Hague: Mouton, 1970).

Phelps, Reginald, “'Before Hitler Came”: Thule Society and Germanen Orden', The Journal of Modern History 35, Issue 3 (September 1963), pp. 245-26I.

Pitsch, Ilse, Das Theater als politisch-publizistisches Führungsmittel im Dritten Reich (Münster: D.Phil. Diss. 1952).

Pogge von Strandmann, Hartmut and Geiss, Immanuel, Die Erforderlichkeit des Unmöglichen: Deutschland am Vorabend des ersten Weltkrieges (Frankfurt/Main: Europäische Verlags-Anstalt, 1965).

Pross, Harry, Literatur und Politik: Geschichte und Programme der politisch-literarischen Zeitschriften im deutschen Sprachgebiet seit I 870 (Freiburg im Breisgau: Walter, 1963).

Pulzer, Peter, The Rise of Political Anti-Semitism in Germany and Austria (New York: Harvard University Press, 1988).

Pulzer, Peter, Jews and the German State: The Political History of a Minority, $1848-1933$ (Oxford: Blackwell, 1992).

Pulzer, Peter, Germany I870-I945: Politics, State Formation, and War (Oxford: Oxford University Press, 1997).

Puschner, Uwe, Die völkische Bewegung im wilhelminischen Kaiserreich: Sprache, Rasse, Religion (Darmstadt: Wissenschaftliche Buchgesellschaft, 200I). 
Puschner, Uwe, Schmitz, Walter and Ulbricht, Justus H. (eds), Handbuch zur 'Völkischen Bewegung' I87I-I9I8 (Munich: Saur, 1999).

Rabinbach, Anson G., 'The Aesthetics of Production in the Third Reich', The Journal of Contemporary History II, No. 4 (October 1976), pp. 43-74.

Rauschenbach, Brigitte (ed.), Erinnern, Wiederholen, Durcharbeiten (Berlin: Aufbau, 1992).

Reichel, Peter, Vergangenheitsbewältigung in Deutschland: Die Auseinandersetzung mit NS-Diktatur in Politik und Justiz (Munich: Beck, 2007).

Retallack, James, The German Right, I860-1920: Political Limits of the Authoritarian Imagination (Toronto: University of Toronto Press, 2006).

Riordan, Colin (ed.), Green Thought in German Culture: Historical and Contemporary Perspectives (Cardiff: University of Wales Press, 1997).

Ried, James, 'The Poet House of Prussia,' The Times Literary Supplement, 22nd June 1973.

Ritchie, J.M., German Literature under National Socialism (London: Croom Helm, 1983).

Rosenbaum, E., 'Die Konservative Revolution in Deutschland, 1918-1932', International Affairs 27, No. 2 (April 195I), pp. 240-24I.

Rothe, Wolfgang (ed.), Die deutsche Literatur in der Weimarer Republik (Stuttgart: Reclam, 1974).

Sarkowicz, Hans and Mentzer, Alf, Literatur in Nazi-Deutschland: Ein biografisches Lexikon (Hamburg/Wien: Europa Verlag, 2000).

Schirer, William L., The Rise and Fall of the Third Reich: A History of Nazi Germany (London: Secker \& Warburg, 1959).

Schmitz, Helmut (ed.), A Nation of Victims? Representations of Wartime Suffering from 1945 to the Present (Amsterdam: Rodopi, 2008).

Schoeps, Karl-Heinz Joachim, Literatur im Dritten Reich (Bern: Lang, 1992).

Schonauer, Franz, Deutsche Literatur im Dritten Reich: Versuch einer Darstellung in polemisch-didaktischen Absicht (Freiburg: Walter Verlag 196I).

Schroll, Heike, 'Die Bergungsstelle für wissenschaftliche Bibliotheken und Archive des Magistrats von Berlin', in Jürgen Wetzel (ed.), Berlin in Geschichte und Gegenwart: Jahrbuch des Landesarchivs Berlin 2000 (Berlin: Mann, 2000), pp. I35-I54.

Schuldt-Britting, Ingeborg, Sankt-Anna-Platz 1o: Erinnerungen an Georg Britting und seinen Münchener Freundeskreis (Munich: Buchendorfer Verlag, 1999).

Schumann, Detlev, 'Gedanken zu Hofmannsthals Begriff der "Konservativen Revolution"', PMLA 54, No. 3 (September 1939), pp. 855-899.

Schütz, William Wolfgang, Pens Under the Swastika (London: S.C.M. Press, 1946).

Schwarz, Hans-Peter, Der konservative Anarchist: Politik und Zeitkritik Ernst Jüngers (Freiburg: Rombach, 1962). 
Schrenck-Notzing, Caspar, Charakterwäsche: Die amerikanische Besatzung in Deutschland und ibre Folgen (Stuttgart: Seewald, 1965).

Segebrecht, Wulf (ed.), Der Bamberger Dichterkreis, 1936-1945: Eine Austellung in der Staatsbibliothek Bamberg (Bamberg: Lang, 1987).

Smith, Anthony D.S., Nationalism in the Twentieth Century (Oxford: M. Robertson, 1979).

Sontheimer, Kurt, Antidemokratisches Denken in der Weimarer Republik: Diepolitischen Ideen des deutschen Nationalismus zwischen I9I8 und 1933 (Munich:dtv, 1994).

Spotts, Frederic, Hitler and the Power of Aesthetics (London: Hutchison, 2002).

Stark, Gary, Entrepreneurs of Ideology: Neoconservative Publishers in Germany, I890-1933 (Chapel Hill: University of North Carolina Press, I98I).

Stern, Fritz, The Politics of Cultural Despair: A Study in the Rise of the Germanic Ideology (Berkeley: University of California Press, 1961).

Stern, Howard, 'The Organisation Consul', Journal of Modern History 35, No. I (March 1963), pp. 20-32.

Sternburg, Wilhelm von, Carl von Ossietzky: Es ist eine unheimliche Stimmung in Deutschland. Eine Biographie (Berlin: Aufbau, 1996).

Strothmann, Dietrich, Nationalsozialistische Literaturpolitik: Ein Beitrag zur Publistik im Dritten Reich (2nd Edition: Bonn: Bouvier, 1963).

Sünner, Rüdiger, Schwarze Sonne: Entfesselung und Missbrauch der Mythen in Nationalsozialismus und rechter Esoterik (Freiburg: Herder, 1999).

Taylor, Ronald, Literature and Society in Germany, I9I8-1945 (Brighton: Harvester, I980).

Tauber, Kurt P., Beyond Eagle and Swastika: German Nationalism since 1945 (Middletown: Wesleyan University Press, 1967).

Thunecke, Jörg (ed.), Leid der Worte: Panorama des literarischen Nationalsozialismus (Bonn: Bouvier, 1987).

Triebel, Florian, Der Eugen Diederichs Verlag, 1930-1949: Ein Unternehmen zwischen Kultur und Kalkül (Munich: C.H. Beck, 2004).

Ulbricht, Justus and Werner, Mieke (eds), Romantik, Revolution und Reform: Die Eugen Diederichs Verlag im Epochenkontext, 1900-1949 (Göttingen: Wallstein, 1999).

Ullrich, Völker, Die nervöse Großmacht I87I-I9I8: Aufstieg und Untergang des deutschen Kaiserreichs (Frankfurt am Main: Fischer, 1999).

Vondung, Klaus, Völkisch-nationale und nationalsozialistische Literaturtheorie (Munich: List, 1973).

Wachsmann, Nikolaus, 'Marching under the Swastika? Ernst Jünger and National Socialism, I918-33', Journal of Contemporary History 33 (October 1998), pp. 573-589.

Wagner, Hans-Ulrich, 'Volk ohne Raum: Zur Geschichte eines Schlagwortes', Sprachwissenschaft 17 (1992), Heft I, pp. 68-109. 
Waite, Robert G.L., Vanguard of Nazism: The Free Corps Movements in Postwar Germany, 1918-1923 (New York: Norton, 1952).

Waite, Robert G.L., The Psychopathic God:AdolfHitler (New York: Basic Books, 1977).

Ward, Stephen R., The War Generation: Veterans of the First World War (Port Washington: Kennikat Press, 1975).

Welch, David, The Third Reich: Politics and Propaganda (London: Routledge, 1993).

Wertheimer, Jack, “"The Unwanted Element”: East European Jews in Imperial Germany', Leo Baeck Institute Yearbook, Ig8I (New York: Secker \& Warburg, 198I).

Winkler, Heinrich August, 'Reshaping the German Right: Radical Nationalism and Political Change', The Journal of Modern History 54, No. I (March 1982), p. 170.

Winkler, Heinrich August, Weimar, 1918-1933 (Munich: Beck, 1998).

Winkler, Heinrich August, Der lange Weg nach Westen, vol. I (Munich: Beck, 2002).

Woods, Roger, The Conservative Revolution in the Weimar Republic (Basingstoke: Macmillan, 1996).

Zimmer, Oliver, Nationalism in Europe, $1890-1940$ (Basingstoke: Palgrave Macmillan, 2003).

Zimmermann, Moshe, Wilhelm Marr: The Patriarch of Anti-Semitism (Oxford: Oxford University Press, 1986). 



\section{Index}

Adenauer, Konrad (Chancellor) 285, 298, 328, 329, 343

Akademische Orchester-Vereinigung,

Göttingen 250-251, 253, 263

Albert Langen Verlag 58-59, 66 and Simplicissimus 58

Alldeutscher Verband 14, 46-53 Alldeutsche Blätter 48 and the Jews $47-48,50$

Allied occupation of Germany 268, $284-287,322,345$

Occupation Statute 313

Alverdes, Paul 58, 74, 219-220, 221-223, 224, 225, 227, 229, 230-23I, 237, 249, 254-255, 258, 316

Anacker, Heinrich 125

Andersch, Alfred 3 IO

$$
\text { Der Angriff 87-89 }
$$

'Anschluß' with Austria (1938) I53, 229-23I, 250

anti-Semitism 5, 24, 25-29, 30, 34-35, $44-45,47-48,50-51,53,54,62$, 7I, 80, 82-83, 90, 93, II3, II4, II9, I2I, I27-I28, I43-I44, I5O, I62, 170, 187, 294-295, 301, 349

Antisemitismusstreit see Preußische Jahrbücher

and literary criticism 29-34, I27-I28

Arnd, Ernst Moritz 36

Arnim, Achim von 125

'Aryanisation' of the publishing industry 234-236

Ausschuß zur Neuordnung der Berliner Stadt- und Volksbüchereien II8
Austro-Prussian War 229

Avenarius, Friedrich 30-3I

Bartels, Adolf 29-34, 35, 40, 43-44, 5I-55, IOI, I25, I26-I28, 315

Barthel, Ludwig Friedrich 224-225

Baumann, Gerhard 127

Bechly, Hans 53, 54, 237

Beethoven, Ludwig van 160

Befreiungsgesetz (1946) 301

Benn, Gottfried 166, 168, 169, 175-176

Bentler, Prof. Ernst 137

Beraer Zeitung 270

Bergengruen, Werner 302

Berliner Börsenzeitung 87

Berliner Tageblatt 64-65

Bernhard, Georg IIs

Bertelsmann Verlag 243-244,319-322

Beste, Konrad 237, 240

Bethge, Bruno I30, I33

Beumelberg, Werner 170-I71, I72, 173, I96 n, 209, 2I3, 2I 4, 225

Billinger, Richard 74

Binding, Rudolf G. 2, 19, 133, 166, I69-I70, I83, I84-I86, I89-I95, 2OI-2O3, 2O4, 206-2O8, 2II-2I2, 2I3, 2I 4, 22I, 224-225, 228, 249-250, 252, 254-255, 258, 260-26I, 263, 274, 312, 316

and Starnberger Kreis 224-225 and World War One 225, 249

Bischoff, Friedrich 225, 255, 258, 320 Bismarck, Otto von 88 Bloem, Walter Julius 255 
Blunck, Hans Friedrich 68, 106, 109, II2, I2I-I22, I25, I3I-I32, I4O, I46, I47, I50, I63, I70-I7I, I73, I74, I83, I90, I9I, I92, I94, I99-200, 209, 224, 237, 240, 245, 247, 257-258, 259, 292

and denazification $29 \mathrm{I}$

Blunden, Edmund 259, 296-297 article in German Life and

Letters 259

'Blut und Boden' 7, 35-36, I12, 245-246 Boer War 66, 69

Böhme, Herbert 276

Bolshevism, opposition to $24,86,88$, I44, 290, 295, 298, 336-340, 343, 345,350

Bonsels, Waldemar 67, I23

book burning I, II 4-II7, II 8, 236

Börsenverein der deutschen Buchhändler 234 and Börsenblatt des deutschen Buchhandels 73

Bouhler, Phillip and Parteiamtliche Prüfungskommission zum Schutz des NSSchrifttums (PPK) II4, 234

Brandenburg, Hans 136

Brecht, Bertolt 72

Brehm, Bruno I30, 230, 254-255, 258

Britting, Georg 74, 224

British Empire 69, 70, 71-72, 230, 231, 262

Bruckmann, Hugo IOI, I50-I5I

Brüning, Heinrich 6I

Buber, Martin 133

Bubis, Martin 282-283

Bülow, Chancellor Bernhard von 42, 47 Bund deutscher Mädel (BDM) I28, 257

capitalism, völkisch critique of $23,24,38$, 49, 70-72, 76, 102, 311, 335-336
Carossa, Hans 136, 170, 258, 274, 295, 316 and Europäische Dichterunion 316 censorship in the Third Reich IOO, IIO, III, II6-124, 218-219, 232-236 under the Allies' Occupation of Germany after I945 300, 309-310, 3II-318

Chamberlain, Eva IOI

Chamberlain, Houston Stewart 5, 28-29, IOI, II3, I28, I5O, 312

city versus country $34-40$

class struggle 88,90, 102, I44, 197

Claß, Heinrich (pseudonym: Frymann, Daniel) 46-48, 49, 50

Claudius, Hermann 225, 237, 255, 258, $263,267,272,295,320$

Clauß, Eugen 54

Clay, Hans 54

Cold War 3II, 338, 344

collective guilt 268, 280, 282-29I, 328

colonies 24, 66, 69-70; see also Grimm, Hans

communism, opposition to $82,88-89$, 94, II8-II9, I24, I68, 30I, 3II, 343

compensation for victims of the Nazi regime 286,340

Conservative Revolution 10-16, 76

Currency Reform (1948) 330

Csaki, Richard (Director, Deutsches Auslands-Institut) I40

Dahn, Felix 125

Darré, Walter 36, 247

Däubler, Theodor 166

Deister-und Weserzeitung 272

'Denazification' 159, 279, 285, 291-308, $331-333,345$

Dessin, Gustav 319-320

Deutschbund 48-49, 5I

Deutschbundblätter 49 
Deutsche Allgemeine Zeitung 254

Deutsche Arbeitsfront (DAF) 238, 240, 242, 243

Deutsche Christen I28-I29

Deutsche Gewerkschaftsbund (DGB) 57,334

Deutsche Nationale Zeitung 236

Deutsche Partei (DP) 327

Deutsche Reichspartei (DRP) 275-276, 327-329, 334

Deutsche Rundschau 316

Deutsche Studentenschaft IIS

Deutsche Verlagsanstalt 220

Deutsche Volkspartei (DVP) 57

Deutsche Zukunft 257

Deutscher Kulturbund 310

Deutscher Nationalpreis für Kunst und Wissenschaft 130

Deutsches Kulturwerk europäischen Geistes 276

Deutsches Volkstum 60-6I

Deutschnationale Volkspartei (DNVP) 57, 91, 97, I3I

Deutschnationaler HandlungsgehilfenVerband (DHV) 53-57, 58 , 6o-65, 237-238 and Deutsche Handels-Wacht 64 and Deutsche Hausbücherei 54-57, 59,61

and Die Herdefeuer 54 and the Jews 53

Deutschvölkische Partei, see Werner, Ferdinand $5 \mathrm{I}$

Deutschvölkischer Bund 52 and Deutschvölkische Blätter 52,53

Deutschvölkischer Schutz- und Trutz-

Bund (DVSTB) $5 \mathrm{I}-53$ and the Hammerschläge Series 52-53

Dickens, Charles 44

Diederichs, Eugen 235-236 and Die Tat 236 and Eugen Diederichs Verlag 54, 58 , 235-237, 330

Diederichs, Niels 236

Diederichs, Peter 236

Dinter, Artur 125

Döblin, Alfred 58, 72, 165-166, 167, 169, 302

Dönitz, Karl 272

Döring, Richard 54

Druffel Verlag 326

Dwinger, Edwin Erich 225, 255, 258, 315 and denazification 293

East Prussia 87, 134-I36, 260, 268, 272, $304,306,330,340$

Eduard Avenarius Verlag $3 \mathrm{I}$

Eher Verlag I27, 131, 218, 232, 234-235, 24I

Ehrhardt, Arthur 276, 327,34I and Nation Europa 276, 324-325, $327,340,341-342$

Engel, Eduard 127-I28

Enlightenment, the $14,39-44,49$, IIO, I20, I59-I60, I64

Ernst, Paul 59, 74, I63, 177, 210, 225-226, $237,247-248$

Euringer, Richard 62, 130, 237, 240

Europa Verlag 235

European Integration 269, 306, 327, $338-339,340-344,350$

exiles from Germany 7, 144, 157, 202, 214, 259, 264, 271, 294, 302, 343

Falange (Spain) 342

Fechter, Paul 258

Federal Republic of Germany (FRG)

$$
\begin{gathered}
3,20,144,265-267,268,27 \mathrm{I}, 273, \\
277,28 \mathrm{I}-282,285,307,312-313, \\
324,327,334,342,348,350,352 \\
\text { Basic Law 28I, 285-286, 311, 313, } 334
\end{gathered}
$$

Feuchtwanger, Leon 58

Fiedler, Prof. Herman 259 
Fischer, Renate von 268, 272

Fischer, Walter 24I

Fisher, Geoffrey, Archbishop of

Canterbury 288

Förster, Friedrich Wilhelm IIs

Franck, Hans 62

Frank, Leonhard 58, 170

Frank, Walter 272

Frankfurter Zeitung 139, 254

Frankfurter Zeitung und

Handelsblatt 164

Freie Presse (Bielefeld) 274

Freikorps 79-81, I52

Frenssen, Gustav I4, 39-40, 4I-45, 7I,

$$
\text { I25, 128-I29 }
$$

and the Jews 44-45

and Social Darwinism 4I, 44, 70

Freud, Sigmund IIs

Freytag, Gustav 26-27, 44, I25

Frick, Wilhelm 153, 155, 247, 261-262

Fricke, Bruno see Deutsche Nationale

\section{Zeitung}

Fritsch, Theodor 51, II2, I50

Führerprinzip I2, 13, I8, 24, 25, 78, $83,93,154,157-158,179,180$, 194-195, 198

Fulda, Ludwig 166, 168, 169, 170

Fulda-Bote 270

Funk, Staatssekretär 149

Fusenegger, Gertrud 230

Gabetti, Prof. Guiseppe 259

Geheeb, Reinhold 24I

Georg Müller Verlag 58-59

German Democratic Republic

(GDR) 20, 267, 268, 273, 28I

German Sonderweg 5-6n

Germania 254 Die Gesellschaft 39

Gesetz zur Wiederherstellung des Berufsbeamtentums 170
Gläser, Ernst iIs

Gleichschaltung 109, I43, I57

libraries II4-I22

literature prizes 130

literature Section of the Prussian Academy of Arts 167-169, 180, I83, 195, 203, 208

publishing industry $235-245$

Goebbels, Joseph 18, 84-85, 87-90, 9I, 92, 103, 104, 107-108, 109, IIO, III, II3, II 4, II6, I22, I3O, I33, I4I-I42, I46-I47, I5I-I52, I53, I6I, I8I-I82, I88, I96, 203 , 204-208, 212, 218, 223, 227, 228, 245, 248, 254, 256, 257, 26I-262, $263-264,279,315,316,317,327$

Goethe, Johann Wolfgang $125,133-138$, I60, 236, 265, 268

Goethepreis der Stadt Frankfurt am Main 130, 133-136

Gollancz, Victor 287

Goltz, Joachim von der 225, 255, 320

Goote, Thor I25

Göring, Hermann 161, 206-208, 209

Göttinger Nachrichten 256

Göttinger Tageblatt 251, 253, 274

Grabelentz, Hans von der 247

Grabenhorst, Georg 255, 258, 272

Die Grenzboten 30

Griese, Friedrich 62, 237, 315

Grillparzer Preis, Vienna I40

Grimm, Hans 2, 8, 16, 19, 21, 42-43, $58,65-74,84-92, \mathrm{IOI}-\mathrm{IO} 4$, 109, II6-II7, I2I, I25, I40-I4I, I44, I45-I50, I5I-I56, I60, I63, 170-17I, 172, 177, 179-180, I8I-I83, I84-I95, I96, 200-203, 204, 205-208, 2IO, 2II-2I 4, 22I, 223, 225, 228, 231, 237, 239, 240, 24I-244, 245, 247, 248, 249-277, 280, 285, 287, 288-291, 295-299, 
300-301, 302, 304, 312-313, 314, $316-322,347,349$

and Africa 4I, 42, 43, 66, 68-71, 86, I46, 259, 269

and ban in

Schleswig-Holstein 329-340

and colonialism 42, 66-71, 23I

and denazificaion 29I-294,

and Deutsche Reichspartei

(DRP) 327-329

and eugenics 335-336,339

and Klosterhaus Verlag 294, 321-322,

$34 \mathrm{I}$

and Lippoldsberger Dichtertreffen

19, 85, 188, 218, 225, 245-246,

249-264, 265-277, 293, 296,

300-301, 351, 322, 323-325

and Nation Europa 344-345

and Reichsverband deutscher

Schriftssteller 148-150

Grimm, Holle 276

Grimm, Wernt 152, 190

Grimme, Adolf 165

'Gruppe 47' 310

Gundolf, Friedrich 67

Haake, Heinz (Landeshauptmann, Rhine Province) 133

Habermann, Max 54, 61

Hamburger Rundfunk 317-318

Hamsun, Knut 92, 237, 312

Hannoversche Allgemeine Zeitung 273

Hannoversche Presse 276

Hannoverscher Kurier 250

Hanseatische Verlagsanstalt (HAVA)

$54,58,60-62,74,220,235,238$,

240, 24I

Hartmann, Wolf Justin 240

Harzburg Front 84-85, 86-87

Hauptmann, Gerhard 209

Hebbel, Friedrich 30
Hederich, Karl Heinz I50

Hedin, Sven 312

Hegemann, Walter iis

'Heimatkunstbewegung' 35-40, 8I and 'Heimat' movement 36

Heine, Heinrich $32-33,55, \mathrm{I} 28$ proposed memorial in Hamburg (1906) 32

Herder, Johann Gottfried 236

Herold Verlag 234

Hess, Ilse 325-326

Hess, Rudolf 90-91, I55-156,, 207, 227, $228,238,248,272,338$

Hesse, Hermann 42, 133, 165

Hessische Nachrichten 270, 273

Heuser, Prof. Frederick W. J. 258-259, 274, 295, 296-298, 299, 30I

Himmler, Heinrich 227-228 and the SS 257, 264, 343

Hindenburg, Paul von, Reichspräsident I5I

Hinkel, Hans (Secretary, RSK) II 2 n, 213

Hinrichs, August 272

'Historikerstreit' 282-283 n

Hitler, Adolf $83-84,88,90,92,103$, I05, $107-108,113,157,188,197$, 203 n, 206, 208, 2I2, 229, 230-23I, 258, 273, 282, 290-291, 300, $301,315,325,333,334,337-339$, $342-343,350$

election as President I5I-I54 foreign policy 230-231, 350

Hitler Jugend I28, 257

Hofmannsthal, Hugo von II

Hohoff, Curt 220-221, 226, 347

Holm, Korfiz 24I

Holocaust 349

and memory $283-284$

Huch, Ricarda 125, 169-170

Hugenberg, Alfred 60 
Husserl, Edmund 133

Impuls (student magazine
Göttingen)

Insel-Verlag 220

internationalism 6, 13, 24, 45, IOI, IO2, 160

'Inner emigration' 7, 184, 209-215, $221-222,280$

Irwahn, Johannes 54

J. Engelhorns Nachfolger - Adolf Spemann Verlag I4I, I42

Jahn, Moritz 255, 258, 263, 267, 272, 273

Johst, Hanns 74, IOI, I03, II2, I25, I30-I3I, I40, I42, I50, I69, 170-171, I72, I73, I78-179, 191-192, 193-196, 199, 204-207, 209, 211, 213, 214, 219, 237, 238, 247,315

and denazification 29I

and Kampfbund für deutsches Schrifttum 103

Jünger, Ernst I2, 74, 84, I46, 170, 312, 345

Kaiser, Georg 170

Kaiserreich 2, 4, 8, I0, I2-I4, I5, $23-25,38,46,48,72,75,78$, $83,97,280,348$

Kammer der Kunstschaffenden 316-317 Kampfbund für deutsche Kultur

$(\mathrm{KfdK})$ 59, $\mathrm{IOI}-\mathrm{I03}, \mathrm{I13}, \mathrm{I2O}, \mathrm{I2} 3$, I6I-I62, I69, 207, 238

and Deutsche Kultur-Wacht 169 and Urban, Dr. Gotthard (Secretary $\mathrm{KfdK}) 238$

Kant, Immanuel 160

Kasseler Post 274, 328-329

Kasseler Zeitung 275

Kästner, Erich II5-116, 302

Kautsky, Karl IIs
Keller, Paul Anton 230

Keller, Stadtrat Dr. 137

Kellermann, Bernhard 169, I70

Kerr, Alfred II5, 302

Kinau, Johann Wilhelm (Gorch Fock) 54

Kleist, Heinrich von I25

Knorr \& Hirsch Verlag 24I

Kölnische Volkszeitung 260

Kolbenheyer, Erwin Guido 2, 16, 19 , 2I, 59-65, 72, 74-75, 93-97, 98, IOI, I03, I33, I36-I46, I58-167, 170-17I, I72-175, I76-179, I80, I84-195, 195-203, 204, 205, 210 , $213 \mathrm{n}, 214,218,224,225,237-243$, 246, 247-248, 250, 263, 285, 295, 299-304, 305, 306, 311-312, 314, 318, 345, 347-349

and 'biological socialism' 197-198 and 'denazification' 291-292 and Kolbenheyer Gesellschaft 304 and Kolbenheyer Preis, Karlsbad I40 and NSDAP 301 and Sudetendeutscher

Kulturpreis 292

Kommunistische Partei Deutschlands (KPD) 167

Kordt, Erich 326, 329

Krause, Karl 64

Krauß, Christian 54

Krebs, Fritz 133, 135

Kulturbund zur demokratischen

Erneuerung 317

Kulturliga, Munich 310

Der Kunstwart 30

Lagarde, Paul de 5, 3 I

Lagerlöf, Selma 237

Landesberatungsstelle für volkstümliches Büchereiwesen und Jugendschrifttumspflege Thüringen 125 
Landesverband der

Vertriebenen Deutschen

(Schleswig-Holstein) 332

Langbehn, Julius 5, 3I

Lange, Friedrich see Deutschbund

Langebeck, Curt 133

Langen-Müller Verlag 19, 57-65,

$73-75,124,192,217,224,226$,

$227,232,235,236,237-245$,

254, 260, 263, 300, 319-320,

347,351

and Das Innere Reich 218-232

Langhans, Paul 5I

League of Christian Unions 57

League of Nations 82, 86, 102

Lehmann, Julius F. 49, IOI,

$$
235-236
$$

and J. F. Lehmanns Verlag 54, 58, 235-236

Lersch, Heinrich 133,170

Ley, Robert 238, 243

Licensed Press 298, 328

Lienhard, Friedrich 34-35, 44, 68

Lilien, Ephraim Moses 187

Lilienfein, Heinrich 247-248

'Lippoldsberger Dichtertreffen' see Grimm, Hans

Die literarische Welt 166

Literarisches Centralblatt 43

literature prizes I29-I42

Literaturpreis der Stadt München 136

Literaturpreis des Goethebundes

Bremen 136

Locarno Treaty 154

Loerke, Oskar 166, I68

Löns, Hermann 39-40, I25

Lorenz, Ludwig 32-33

Ludendorff, Mathilde 3 I2

Ludwig, Emil ins

Ludwig, Otto 30

Luther, Martin 160, 236
Maass, Dr. Max 250

Mahnke and Nationaldemokratische

Partei Deutschlands (NPD) 270

Mahnke, Heinz 268

Malthus, Thomas 335

Mann, Heinrich 58, 100, II5, I66, I 67-169, 302

Mann, Thomas 66, 72-73, 100, 162, I64, 165-166, 169, 172

Mannheimer Morgen 304

Marr, Wilhelm 28

Marx, Karl IIs

Marxism, opposition to 102, 159, 294, 343

Mechow, Karl Benno von 58, 74, 219-220, 221-223, 224, 227, 229, $237,249,258$

Mell, Max 166

Meschendörfer, Adolf (Auslands-Institut) 140

Miegel, Agnes 2, I34-136, I57, I70-I71, 225, 247, 291, 293, 295, 304-307, 322, 329-330

Miltzow, Hermann 237

Moeller van den Bruck, Arthur 51, 67, 76-78, 8I, 95, I25

and Juniklub 67-68

Mohn, Heinrich 319-32I

Mohn, Reinhard 320

Möller, Eberhard Wolfgang 130

Molo, Walter von 166, 173

Mombert, Alfred 170

Mommsen, Theodor 27

Morgenthau Plan 286-287, 318

Mosley, Diana 340-34I

Mosley, Oswald 340-34I

Mosse Verlag 62

Movimento Sociale Italiano (MSI) 342

Müller-Grote, Carl 45

Münchhausen, Börries Freiherr von

$$
\text { 2, 19, 42, 67-68, 163, 170-174, }
$$


I77, I84-I95, 20I-203, 204, $214,245-249,255,257-258$, 274, 304, 306

and anti-Semitism $\quad 187$ and Wartburg Dichtertage I88,

245-249, 257-258

'Munich Consensus' 19, 21, I84-195, I96, 200, 20I, 202, 203-206, 208, 209, 210, 213-215, 219, 220, 22I, 239, 249, 264, 280, 285, 347, $35 \mathrm{I}$

Musil, Robert 58

Mussolini, Benito 315

Mutschmann, Martin (Reichsstatthalter, Gau of Saxony) I3I

Nadler, Josef $37-38$

National Conservatives $15-16$

National Liberals 47

National Theatre Festival for German Youth 32-33

Nationalsozialistischer Deutscher Studentenbund IIS

Nationalsozialistischer Schülerbund 127

Naumann, Werner 327, 328-329

Navy League I4, 42, 49

Nazi-Soviet Pact, 1939326

Neue Presse 276

Die neue Zeitung 314-315, 316

Neumann, Alfred 59

Neurath, Konstantin Freiherr von 272

Niemöller, Martin 226

Nobbe, Uwe Lars 255, 258

Norddeutsche Rundschau 331

NSDAP 8, I8, 56, 57, 83-92, 97, 99, 100, IOI, IO3-IO5, IO7, II2, II4, I22, I27, I29-I3I, I33, I34, I 42-I44, I46, I50, I5I, I88-I89, 200, 202, 207, 213, 218-219, 227, 232, 235, 237-238, 239, 24I, 245-246, 257,
$265,292-293,300,302,306$, 312,320

Nuremberg War Crimes Trials 272

Oberste Heeresleitung 67, 259

Öffentliche Bücherhalle, Hamburg and Lampe, Friedrich 125-I26 and Schuster, Wilhelm (Director) 117, II 8

Oldenbourg, Friedrich II2, 234

Organisation Consul 79-80

Ossietzky, Carl von Ioo, IIs and Nobel Peace Prize 130

Pannwitz, Rudolf 166, 170

Paquet, Alfons 166, 169

Paracelsus 160

Paracelsus Prize, Villach 139

Peter, Ursel 268

Pezold, Gustav 62-64, 65-66, 68, $72-74,218,219,227,229$, $238-243,263,300,319-320,351$

Pleyer, Wilhelm 268, 27I

Politik und Wissenschaft 275

Ponten, Josef I63, I64

Potsdam Conference 308

Preußischer Jahrbücher 27

Preußisches Kultusministerium II8, I66, I73, 175

Prussian Academy of Arts 15, 19, 59, 63, I06, II6, I34, I57, I62, I67-I70, I74-I76, I78, I8I, 203, 204, 208, 209, 210, 2II, 247, 300, 305

and German Literature Academy I57-I58, I60, I6I, I63-I67, I7I-196, 199, 200-217, 237, 237, $248,249-250,254,256,260,263$, 292, 304, 306, 35I

and Literature Section I5, 19, 59, 63, 106, I34, I57, I62-165, 167-168, I7I, I75, I76, 207, 247 
Raab, Hans 53, 54, 237

Raabe, Wilhelm 30

Raeder, Erich 272

Rainer, Friedrich (Gauleiter, Corinthia) 139

Reactionary Modernism I4

'Re-education' (after World War II) I59, 279, 285, 308-322, 345

licensing of publishing $318-322$

Rehkopf, Willi 250

Reichshammerbund see Fritsch, Theodor

Reichskammergesetz I47-I48

Reichskulturkammer (RKK) IO7, IIO-II2, I45, I8I, I99-200, 203

Reichskultursenat I5I

Reichsministerium für Volksaufklärung und Propaganda (RMVP) I07, IIO, II2, II4, II7, I20, I36, I4I-I42, I5I, I8I, 205, 207, $2 \mathrm{II}$, $245,317,327$

Beratungsstelle Verlag 233

Erckmann, Rudolf, Referent für Deutsches Schrifttum I4I

Literaturabteilung IIO, III, 232, 233

Reichsstelle zur Förderung des deutschen Schrifttums IIO, II3-II4, I23, 206

Reichsverband Deutsche Bühne II 4 Reichspressekammer II2

Reichsrundfunk I5I

Reichsschrifttumskammer (RSK)

IO3, IO6, IO8, IIO-II2, II3, I2O-I2I, I23, I24, I3O-I3I, I4O, I45, I46-I49, I78, I8I-I83, I88, 192, I94, 200, 203, 204, 2II, 2I2, $213,232-233,234,240,254,260$, 279, 292

Baur, Wilhelm

(Vice-President) 239-240

Heinl, Dr. Karl 122

Ihde, Wilhelm (Secretary) 130-I3I
Reichstag fire (27.02.1933) II8

Reichsverband Deutscher Schriftsteller (RDS) $120,148-150$

Reichswehr 249-250, 257, 264

Remarque, Erich Maria 79, I00, IIs

Rembrandt 160

Remhof, Friedrich 154-I55

re-militarisation of the Rhineland I54, 262

Resistance (against the Nazi regime) 66,266 20th July bomb plot 30I, 326

Die Rheinlande 39, 8I

Ribbentrop, Annelies von 266,322-323, 325-327, 329

Ribbentrop, Joachim von 156, 228, 266, 338

Richter, Hans Werner 310

Riehl, Wilhelm Heinrich 36

Rosegger, Peter 44

Rosenberg, Alfred I8, 89-90, 9I, IOI-IO4, IO7, IO9, II2-II4, I23, I6I, 206-207, 238, 257, 309

Beauftragte der gesamten geistigen und weltanschaulichen Schulung und Erziehung der NSDAP II 4 and NS-Kulturgemeinde 114,258 Rotenburger Tageblatt 270

Roth, Alfred 50, 51, 52-53

Rowohlt 220

Rudel, Hans-Ulrich 268, 327

Rundschau zum Sonntag 332

Rust, Bernhard I33, I61, I62, I67-169, I7I, I72-I75, I78-I79, I8I, I99, 203-204, 207-208, 209, 2II, 238,300

Reichsminister für Science, Education and National Culture 207-208

Rütten und Loening Verlag 316 
S. Fischer Verlag 62, 66, 220

Salomon, Ernst von 80, 146, 217, 245, 255 and denazification 293

Sauer, August 37

Schäfer, Wilhelm 2, 16, 19, 21, 60, 68, $74,81-83,92,163,164,165-166$, 167, 170-171, 173, 176-177, 178, I8I-I95, I96, 200-204, 206-208, 209, 213, 214, 218, 224, 225, 237, $238,242,243-244,246,247,250$, $285,295,320,347$

and the Rheinischer Literaturpreis $132-134$

Schaumburg, Ruth ${ }_{136}$

Schemm, Hans (Minister for Culture and Education, Bavaria) 196-197

Scherl-Verlag 60

Schickele, René 165, 170

Schiller, Friedrich 125

Schillerbund 34

Schillings, Max von 167-170, 176, 177

Schirach, Baldur von 33, 247, 272

Schleswig-Holsteinische Landeszeitung 33I, 333

Scholz, Wilhelm von 166

'Schriftsteller versus Dichter' 43-44, I49, I63-I64, I7I-I72

Schröder, Rudolf Alexander 225, 255, 258, $263,274,320$

Schulte-Strathaus, Ernst 190, 227, 248

Schulze-Naumburg, Paul I90, 247

Schumann, Gerhard I30, I40

Schütz, Karl Waldemar and Göttinger Verlagsanstalt 333-334, 335

and Plesse Verlag 322, 334 and Reichsruf 333-334

Seidel, Ina 157, 166, 227, 248, 295

Seidel, Willy 136

Severing, Hans 220

Sleipner Verlag 52
social-Darwinism I4, 28, 4I, 44, 47, 70, 197

Social Democracy 35, 38-39, 69, 53, 82,152

Soeding, Ellen 34I

Soviet Union (USSR) 3, 269, 291, $313,314,326,336,338,340$, 343-345

Sozialdemokratische Partei Deutschlands (SPD) I5, 167, 327, 334

Sozialistische Reichspartei (SRP) 270, 327

Speer, Albert 272

Spengler, Oswald 315

Der Spiegel 328-329

Spranger, Eduard 226

Srbik, Heinrich Ritter von 230

Staa, Ministerialrat Dr. von 176

Stahlhelm 87

Standartes Verlag und Druckerei 234

Standesvertretung 147, 195-203, 350

Stapel, Wilhelm 54, 60-6I, 64, 73, 173

Stefan George-Preis I30

Stegumann, Hermann 133

Steguweit, Heinz 62, 237, 240

Stehr, Hermann 72, 133, 163, 173, 177, 209, 247-248

Strauß, Emil 2, 8, 19, 21, 72, 74, I5 I, I63, I66, I67, I70-I7I, I73, I76-I77, I78, I8I-I82, I84-I95, $20 \mathrm{I}-202,203,206,2 \mathrm{I} 4,2 \mathrm{I} 8$, $237,238,242,246,250,285$, 295, 320, 347

Strauß, Wolfgang 320,322

Strindberg, August 58

Strölin, Karl (Mayor of Stuttgart) I40

Stucken, Eduard 166

Der Stürmer 152

Stuttgarter Neues Tagblatt ${ }_{13} 6$

Sudetenland 137, 159, 230-231, 250, $301-302,306,340$ 


\section{Tempo 168}

territorial expansion 47, 51, 66,

68-70, 77, 94, I46, 230-23I,

3I $4,333,337$

Thadden, Adolf von 276, 327

Thiel, Rudolf 226-227

Third Reich I, 2, 5, 7, 9, 15, 17, 18, 19, 20, 2I, 60, 64, 68, 70, 9I, I03, I04-I06, I07-III, II5, II7-II8, I21, I23, I26-I29, I32, I34, I36, I37, I39, I40, I4I, I 43, I45, I46, I47-I49, I5I, I53-I58, I6I, I64, I7 I I I78, I82, I84, I85, I86, I87, 188, 190, 193, 197, 202-202, 206, 209, 2II, 217-218, 220-221, 224, 225, 229, 232, $236,237,239,244-245$, 249-250, 254, 256, 263-267, 270, 279, 280-282, 294, 307, 312, 314, 317, 319, 325, 337, 338, $342-344,351$

Thompson, Dennis 296-297

Thüringisches Volksbildungsministerium II9, I25

Toepfer, Alfred I3I-I32, I4O and Eichendorff Preis 140 and Hansische Stiftung 132 and Johann Wolfgang von Goethe Stiftung 132

Toepfer, Ernst 132 Treitschke, Heinrich von 27

Tucholsky, Kurt IIs

Tügel, Ludwig 240

Der Türmer 39

Ullstein Verlag 59-60, 62, 234

United Nations 314, 335

Unruh, Fritz von 170

Upper Silesia 180 urbanisation $23-24,38-39,68-69$, II8-II9, I63, 247
USA 77,93, 241, 259, 264, 269, 287, 29I-293, 295, 298-299, 302, 310-312, 314-316, 336, 339,350 anti-Americanism 343-345

Venatier, Hans 268, 271, 276, 323-325

Vereinigung ehemaliger Internierter und Entnazifizierungsgeschädigte 331 , 332,334

Versailles, Treaty of (1919) 17, 76, 78, $8 \mathrm{I}-82,86,94,96, \mathrm{IO} 2, \mathrm{I} 54, \mathrm{I} 59$, I $80,212,230,284,345$

'Vertreibung' 268, 269, 272, 283 n, 307,337

Vesper, Will 62, 170, 173, 175, 247, 267, $272,295,319-320$

and Die neue Literatur 267

Volksdeutscher Schrifttumspreis der Stadt der Auslandsdeutschen, Stuttgart 140

völkisch-national Revolution 97, 104, I5I, I57, 160, 201, 202, 348, 352, I6I, 179, I80, 195, 197, 209, 223, 228, 236, 348,

Völkischer Beobachter 86, 103, 196, 253-254

Volksgemeinschaft I0, I2, I8, 24, 34, 39, $76,78,83,93,109, \mathrm{II}_{3}-\mathrm{II} 4, \mathrm{II}$, I43, I6I, 199, 252, 28I

Vollmer, Dieter see Der Weg

Wagner, Martin 168

Wagner, Winifried IoI

Walser, Martin 282-284

Wandervögel 39

Wassermann, Jakob 59, 170

Wedekind, Franz 58

Der Weg 276, 302, 304, 327

Wehner, Joseph Magnus 74, 136, 237, 240,315 
Weimar Republic 2, 4, 7, 9, 10-17, 25, 3I, 43, 50-5I, 54, 57-60, 65, $67,69,72,76,80-83,87-88$, 93-94, 97-98, 100, $103,104, \mathrm{II}_{3}$, II 6, I20-I2I, I28, I30, I43, I57, I62-I66, I68, I7 I, I76-I77, I8I, I $87-188,204,223,225,235,280$

Weinheber, Josef 230, 295

Weiß, Wilhelm ror

Weiß-Rüthel, Arnold 302

Weizsäcker, Ernst von (memoirs) 326

Die Welt 298, 304, 305

Werfel, Franz 169, 170

Werner, Ferdinand 5I

'white race' 66, 71, 86, 93-97, 159, 198, $306-307,309,318,350$

Wiechert, Ernst 74, I23-I24, 237, 262 and incarceration in Buchenwald 226

'Wiedergutmachung' 286

Wilhelm II, Kaiser 29, 76, 8I-82

Wille und Macht 257

Wilson, President Woodrow 8I and 14 Points 82

Winnig, August 74, 87-89, I12, 258, 263,320

Wirsig, Wolfgang 276

Wismann, Heinz IIO, II2, I22, 238
Wittstock, Erwin I4O

Woche des deutschen Buches 245, 248 and Weimarer Dichtertage

$$
\text { 262,300 }
$$

Wolff, Theodor ins

World Report 297

World War One 12, 13, 17, 24-25, 42, 44, $46-49,54,58,59,60-61,67,70$, $75-83,86,95-97,103,142,150$, I52, I57, I59, I80, I87, 222-223, 225, 227-229, 231, 235, 249, 259, 306,337

World War Two I8, 20, 68, 83, II4, II7, I2I, I35, I38-I39, I42, I89, 208, 23I, 244, 250, 26I-263, 264, 270, 28I, 286, 289, 290-291, 338, 343, $345,349,350$

Die Zeit 298, 305, 327

'Zero Hour' 284

Ziegler, Benno 24I

Ziegler, Hans Severus 247

Zierlik, Otto 303

Zierold, Kurt 173-174, 305

Zillich, Heinrich 224-225, 258, 320

Zimmermann, Albert 54

Zuckmayer, Carl 100

Das zwanzigste Jahrhundert 34-35 


\section{CULTURAL HISTORY AND LITERARY IMAGINATION}

\section{EDITED BY CHRISTIAN J. EMDEN \& DAVID MIDGLEY}

This series promotes inquiry into the relationship between literary texts and their cultural and intellectual contexts, in theoretical, interpretative and historical perspectives. It has developed out of a research initiative of the German Department at Cambridge University, but its focus of interest is on the European tradition broadly perceived. Its purpose is to encourage comparative and interdisciplinary research into the connections between cultural history and the literary imagination generally.

The editors are especially concerned to encourage the investigation of the role of the literary imagination in cultural history and the interpretation of cultural history through the literary text. Examples of the kind of issues in which they are particularly interested include the following:

- The material conditions of culture and their representation in literature, e.g. responses to the impact of the sciences, technology, and industrialisation, the confrontation of 'high' culture with popular culture, and the impact of new media;

- The construction of cultural meaning through literary texts, e.g. responses to cultural crisis, or paradigm shifts in cultural self-perception, including the establishment of cultural 'foundation myths';

- History and cultural memory as mediated through the metaphors and models deployed in literary writing and other media;

- The intermedial and intercultural practice of authors or literary movements in specific periods;

- The methodology of cultural inquiry and the theoretical discussion of such issues as intermediality, text as a medium of cultural memory, and intercultural relations.

Both theoretical reflection on and empirical investigation of these issues are welcome. The series is intended to include monographs, editions, and collections of papers based on recent research in this area. The main language of publication is English. 
Vol. 1 Christian Emden \& David Midgley (eds): Cultural Memory and Historical Consciousness in the German-Speaking World Since 1500. Papers from the Conference 'The Fragile Tradition', Cambridge 2002. Vol. 1. 316 pp., 2004. ISBN 3-03910-160-9 / US-ISBN 0-8204-6970-X

Vol. 2 Christian Emden \& David Midgley (eds): German Literature, History and the Nation. Papers from the Conference 'The Fragile Tradition', Cambridge 2002. Vol. 2. 393 pp., 2004. ISBN 3-03910-169-2 / US-ISBN 0-8204-6979-3

Vol. 3 Christian Emden \& David Midgley (eds): Science, Technology and the German Cultural Imagination. Papers from the Conference 'The Fragile Tradition', Cambridge 2002. Vol. 3. 319 pp., 2005. ISBN 3-03910-170-6 / US-ISBN 0-8204-6980-7

Vol. 4 Anthony Fothergill: Secret Sharers. Joseph Conrad's Cultural Reception in Germany.

274 pp., 2006. ISBN 3-03910-271-0 / US-ISBN 0-8204-7200-X

Vol. 5 Silke Arnold-de Simine (ed.): Memory Traces. 1989 and the Question of German Cultural Identity.

343 pp., 2005. ISBN 3-03910-297-4 / US-ISBN 0-8204-7223-9

Vol. 6 Renata Tyszczuk: In Hope of a Better Age. Stanislas Leszczynski in Lorraine $1737-1766$.

410 pp., 2007. ISBN 978-3-03910-324-9

Vol. 7 Christian Emden, Catherine Keen \& David Midgley (eds): Imagining the City, Volume 1. The Art of Urban Living. 344 pp., 2006. ISBN 3-03910-532-9 / US-ISBN 0-8204-7536-X

Vol. 8 Christian Emden, Catherine Keen \& David Midgley (eds): Imagining the City, Volume 2. The Politics of Urban Space.

383 pp., 2006. ISBN 3-03910-533-7 / US-ISBN 0-8204-7537-8

Vol. 9 Christian J. Emden and Gabriele Rippl (eds): ImageScapes. Studies in Intermediality. 289 pp., 2010. ISBN 978-3-03910-573-1

Vol. 10 Alasdair King: Hans Magnus Enzensberger. Writing, Media, Democracy. 357 pp., 2007. ISBN 978-3-03910-902-9

Vol. 11 Ulrike Zitzlsperger: ZeitGeschichten: Die Berliner Übergangsjahre. Zur Verortung der Stadt nach der Mauer. 241 pp., 2007. ISBN 978-3-03911-087-2 
Vol. 12 Alexandra Kolb: Performing Femininity. Dance and Literature in German Modernism.

330pp., 2009. ISBN 978-3-03911-351-4

Vol. 13 Carlo Salzani: Constellations of Reading. Walter Benjamin in Figures of Actuality.

388pp., 2009. ISBN 978-3-03911-860-1

Vol. 14 Monique Rinere: Transformations of the German Novel. Simplicissimus in Eighteenth-Century Adaptations.

273pp., 2009. ISBN 978-3-03911-896-0

Vol. 15 Katharina Hall and Kathryn N. Jones (eds): Constructions of Conflict. Transmitting Memories of the Past in European Historiography, Culture and Media.

282pp., 2011. ISBN 978-3-03911-923-3

Vol. 16 Ingo Cornils and Sarah Waters (eds): Memories of 1968. International Perspectives.

396pp., 2010. ISBN 978-3-03911-931-8

Vol. 17 Anna 0' Driscoll: Constructions of Melancholy in Contemporary German and Austrian Literature.

263pp., 2013. ISBN 978-3-0343-0733-8

Vol. 18 Martin Modlinger and Philipp Sonntag (eds): Other People's Pain.

Narratives of Trauma and the Question of Ethics.

252pp., 2011. ISBN 978-3-0343-0260-9

Vol. 19 lan Cooper and Bernhard F. Malkmus (eds): Dialectic and Paradox. Configurations of the Third in Modernity. 265pp., 2013. ISBN 978-3-0343-0714-7

Vol. 20 Kristina Mendicino and Betiel Wasihun (eds): Playing False.

Representations of Betrayal.

355pp., 2013. ISBN 978-3-0343-0867-0

Vol. 21 Guy Tourlamain: Völkisch Writers and National Socialism. A Study of RightWing Political Culture in Germany, 1890-1960.

394pp., 2014. ISBN 978-3-03911-958-5 